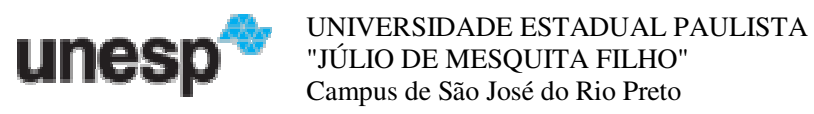

MARIA JOSÉ TEREZINHA MALVEZZI

O ECO DA VOZ CHICANA EXPRESSA EM SINGULARES (DES)CAMINHOS (DES)CONTEXTUALIZADOS NA REDE PÓSMODERNA

São José do Rio Preto

2010 
MARIA JOSÉ TEREZINHA MALVEZZI

\section{O ECO DA VOZ CHICANA EXPRESSA EM SINGULARES (DES)CAMINHOS (DES)CONTEXTUALIZADOS NA REDE PÓS- MODERNA}

Tese apresentada ao Instituto de Biociências, Letras e Ciências Exatas da Universidade Estadual Paulista, Câmpus de São José do Rio Preto, para obtenção do título de Doutor em Letras (Área de Concentração: Teoria da Literatura)

Orientador: $\operatorname{Prof}^{\mathrm{a}} \mathrm{Dr}^{\mathrm{a}}$ Giséle Manganelli Fernandes

São José do Rio Preto

2010 
Malvezzi, Maria José Terezinha.

$\mathrm{O}$ eco da voz chicana expressa em singulares (des)caminhos (des)contextualizados na rede pós-moderna / Maria José Terezinha Malvezzi. - São José do Rio Preto: 2010.

358 f.; $30 \mathrm{~cm}$.

Orientador: Giséle Manganelli Fernandes

Co-orientador : Manoel Fernando Medina

Tese (doutorado) - Universidade Estadual Paulista, Instituto de

Biociências, Letras e Ciências Exatas

1. Literatura norte-americana - História e crítica. 2. Literatura chicana História e crítica. 3. Pós-modernismo (Literatura) 4. Anzaldúa, Gloria Crítica e interpretação. 5. Gómez Peña, Guillermo - Crítica e interpretação. I. Fernandes, Gisele Manganelli. II. Medina, Manoel Fernando. III. Universidade Estadual Paulista, Instituto de Biociências, Letras e Ciências Exatas. IV.Título

$$
\text { CDU -821.111(73).09 }
$$

Ficha catalográfica elaborada pela Biblioteca do IBILCE Campus de São José do Rio Preto - UNESP 
MARIA JOSÉ TEREZINHA MALVEZZI

\section{O ECO DA VOZ CHICANA EXPRESSA EM SINGULARES (DES)CAMINHOS (DES)CONTEXTUALIZADOS NA REDE PÓS- MODERNA}

Tese apresentada ao Instituto de Biociências, Letras e Ciências Exatas da Universidade Estadual Paulista, Câmpus de São José do Rio Preto, para obtenção do título de Doutor em Letras (Área de Concentração: Teoria da Literatura)

\section{Banca Examinadora}

$\operatorname{Prof}^{\mathrm{a}} \operatorname{Dr}^{\mathrm{a}}$ Giséle Manganelli Fernandes

UNESP - São José do Rio Preto

Orientador

Prof. Dr. Álvaro Hattnher

UNESP - São José do Rio Preto

Prof $^{\mathrm{a}} \operatorname{Dr}^{\mathrm{a}}$ Norma Wimmer

UNESP - São José do Rio Preto

Prof. Dr. Paulo Sérgio Nolasco dos Santos

UF da Grande Dourados - MS

Prof. Dr. Manuel Fernando Medina

University of Louisville - Kentucky - U.S.A

São José do Rio Preto

2010 
DEDICO ESTE TRABALHO

Aos meus pais, in memoriam. Dedico-o, também, ao meu sobrinho Enzo, pelo incentivo constante. 


\section{AGRADECIMENTOS}

A Deus, minha referência espaço-temporal.

À Prof ${ }^{\mathrm{a}} \operatorname{Dr}^{\mathrm{a}}$ Giséle Manganelli Fernandes, pela tranquila orientação e desempenho - aporte de vozes manifestando as múltiplas expressões de solidariedade e compreensão.

Ao Júnior, seu esposo, pela sabedoria acadêmica a ser seguida por todos aqueles que querem consumir e promover a aproximação entre interlocutores.

Ao Prof. Dr. Manuel Fernando Medina, pela co-orientação.

Ao Prof. Dr. Álvaro Hattnher e à Prof ${ }^{\mathrm{a}}$ Dr $^{\mathrm{a}}$ Norma Wimmer, pela observação e o contemplar de minhas andanças, um resumo do meu desejo de saber.

À Dn ${ }^{\mathrm{a}}$ Maura e esposo, Sr. Clemente, pelo exemplo de vida anunciado na vontade de ser.

Ao meu irmão, Marcus, que acreditou em mim e me incentivou.

Ao meu sobrinho, Enzo, meu querido amigo.

Ao meu amigo Ricardo Sobreira, pelas expressões de carinho e companheirismo demonstradas desde que nos conhecemos.

Ao meu marido Manoel, um grande companheiro. 


\section{RESUMO}

Esta tese analisa as obras The New World Border (1996), de Guillermo Gómez-Peña e Borderlands/La Frontera: The New Mestiza (1987), de Gloria Anzaldúa, com o objetivo de verificar como esses escritores abordam problemas de identidade enfrentados pelos Chicanos, cidadãos divididos entre as tradições de seus ancestrais e estilo de vida nos Estados Unidos. Para os autores, apenas atravessar a fronteira física México/EUA não significa necessariamente fazer travessia por completo, uma vez que as "fronteiras" culturais e econômicas são as verdadeiras divisoras entre, de um lado, os imigrantes e seus descendentes e, de outro, os americanos. Mesmo assim, os Chicanos lutam para ter voz. Anzaldúa e Gómez-Peña mostram o poder do hibridismo desses imigrantes, representado em suas escritas experimentais, misturando Inglês e Espanhol, prosa e poesia, enfatizando, assim, o rompimento de fronteiras, inclusive o de gêneros literários. A tese examina a importância da Literatura produzida pelos Chicanos, pois seus trabalhos revelam as contribuições culturais e econômicas dessa imigração para a sociedade americana.

Palavras-chave: Pós-modernismo, Literatura Chicana, Estudos Culturais, identidade, Gloria Anzaldúa, Guillermo Gómez-Peña. 


\begin{abstract}
The objective of this dissertation is to analyze The New World Border (1996), by Guillermo Gómez-Peña, and Borderlands/La Frontera: The New Mestiza (1987), by Gloria Anzaldúa, in order to show how these writers approach identity matters faced by Chicanos in the US, since it is not easy for them to choose between keeping their traditions and living the American way of life. According to the authors, the mere act of crossing the Mexico/US border alone does not necessarily result in crossing the "frontiers" that really separate these immigrants and their offspring from Americans, that is, the cultural and economic barriers. Nevertheless, the Chicanos fight for the right to be heard. Anzaldúa and Gómez-Peña reveal the power of Chicano hybridism, represented in their experiments with language, writing in English and Spanish, prose and verse, thus emphasizing the rupture of frontiers, including that of literary genres. This dissertation addresses the importance of the literature produced by Chicanos, since their writings reveal the extent of Chicano contribution to American cultural life and society.
\end{abstract}

Keywords: Postmodernism, Chicano/a Literature, Cultural Studies, identity, Gloria Anzaldúa, Guillermo Gómez-Peña. 


\section{SUMÁRIO}

1- DEFINIÇÃO DO CAMPO DE ANÁLISE

\section{CAPÍTULO I}

1.1 O SIGNIFICADO DE SER CHICANO EXPRESSO POR MEIO DE VOZES LITERÁRIAS

1.2 PRODUZINDO UM MEIO DE SE ENUNCIAR: A ESFERA NARRATIVA

1.3 A MOVIMENTAÇÃO TEÓRICA PARA DISCUTIR OS TEXTOS DE GÓMEZ-PEÑA E ANZALDÚA

3- A EXPRESSÃO DA VOZ CHICANA CONTIDA NOS DITOS E ESCRITOS DE ANZALDÚA E GÓMEZ-PEÑA

\section{CAPÍTULO II}

4- CONHECENDO "BORDERLANDS": O TERRITÓRIO DA TRADUÇÃO EXPRESSO NA VOZ DE ANZALDÚA

4.1 POR UMA VOZ QUE SE QUER INDEPENDENTE: A ALTERIDADE EM ANZALDÚA

4.2 LIBERTAR A REBELDE: PRÁTICAS DISCURSIVAS E PRODUÇÃO DE SENTIDO 
4.2.a A MEIO A MEIO: O SENTIMENTO REGISTRADO NA CARNE QUE SOFRE

4.3 A FORMAÇÃO DE UMA OUTRA ESTRUTURA: A CONSCIÊNCIA MESTIÇA 197

4.3.a A ETERNA PASSAGEM: A CONDIÇÃO DE PERMANECER MESTIÇA

\section{CAPÍTULO III}

5- O ESPAÇO PRESENTE NA ARTE PERFORMÁTICA DE GÓMEZ-PEÑA

5.1 O PÓS-MODERNO EMERGENTE NA OBRA DE GÓMEZ-PEÑA

5.2 IMAGENS DE GÓMEZ-PEÑA EM THE NEW WORLD BORDER: DE UM FRAGMENTO A OUTRO

5.3 A ASTÚCIA ARGUMENTATIVA DE GÓMEZ-PEÑA E SEU ASPECTO INTRÍNSECO DE ERUDIÇÃO

5.4 O LEGADO DE GÓMEZ-PEÑA PARA A CIBERCULTURA: O JEITO DOS LEITORES ACOMPANHAREM

SUAS PROPOSTAS 


\section{Definição do campo de análise}

A sociedade atual caracteriza-se pela busca intensiva de conhecimentos, pela exposição ao convívio com o Outro, e pela conscientização da necessidade de preservar o ambiente em que vive. Essa sociedade, organizada e desenvolvida em meio à revolução tecnológica que se acelerou desde a segunda metade do século XX, redesenhou as interações mundiais gerando novos tipos de desigualdades ou exclusões que mediam o acesso ao conhecimento e aos bens culturais. Neste contexto, ocorre o fenômeno problematizador de identidades, culturas e histórias.

Um dos grupos com relevantes questões identitárias são os chicanos ${ }^{1}$. Esse grupo tem um sentimento de identidade nacional que será analisado, neste trabalho, por meio das obras da escritora Gloria Anzaldúa, texana descendente de mexicanos, e de Guillermo Gómez-Peña, mexicano que foi viver nos Estados Unidos, pois seus textos historicizam suas relações com o México, embasando a contextualização para os escritores examinarem a cultura chicana, confrontação direta entre a ancestralidade mexicana e a cultura norte-americana. Com muito empenho dos artistas, a cultura chicana tem conseguido inverter uma situação desfavorável na América, sugerir uma identidade, determinando um local de onde a sua voz possa falar. Com isso, os autores revelam seu engajamento em um projeto literário e cultural em busca de reconhecimento de seus direitos como cidadãos.

O objetivo deste trabalho será o de estudar como a literatura chicana ${ }^{2}$ reflete a complexidade de inúmeros conflitos e disjunções que se manifestam na cultura, sociedade e política do próprio grupo. Partindo desse ponto de vista, buscaremos focalizar como as personagens, marcadas por tropos de deslocamentos de tempo e espaço, são construídas nas narrativas, como interagem na sociedade local, que lugar ocupam no grupo de origem e nos grupos estrangeiros com os quais convivem, quais perspectivas são priorizadas para suas 
práticas serem desenvolvidas, quais outros espaços são demarcados por elas para construírem e mapearem novas geografias.

Os objetivos gerais deste estudo estão centrados na questão se a literatura chicana ainda pode ser vista como periférica em face de fenômenos contemporâneos, e no estabelecimento de quem tem forças para popularizar sua fala nas expressividades literárias local e transcontinental do mundo globalizado. A complexidade estabelecida pelo discurso direcionador da nova voz daquele que conseguiu se inscrever em um processo no qual encontrava-se subjugado aos antigos padrões e passou a dono de seus desejos, amplia a sua essência criadora por meio de diferentes vozes.

Dessa maneira, o sujeito gramatical, consciente, aquele do "eu” quero, "eu" gosto, logo, o sujeito cartesiano do "penso, logo existo", divide, agora, espaço com o sujeito da enunciação, ou do inconsciente, portanto, o sujeito do desejo. Este passa a expressar suas novas identidades não mais unificadas e fixadas a uma única relação discursiva entre emissor e receptor, mas traz à tona outras vozes até então silenciadas.

Em meio a essas contínuas oposições, o sujeito pós-moderno constrói seu "mundo" pela fala. Uma fala daquele que se sente, de forma paradoxal, sozinho, isolado, único na massificação ao seu redor. Embora "globalizado", está em si e somente consigo mesmo. Dialoga em forma de monólogo com sua própria enunciação.

Nesse sentido, buscaremos refletir sobre determinados enfoques da literatura chicana como diferenciação, e o quanto eles têm sido barrados como meio de divulgação expressiva. Ao serem mantidos sob acirrada vigilância, esses enfoques eram (e ainda o são) impedidos de virem à luz de um modo mais fácil, ou seja, não constituíam até bem pouco tempo, "verdades" interessantes e merecedoras de qualquer tipo de atenção, ou que se apresentassem como lócus de interseção de múltiplas realidades. 
Verificaremos como no contexto pós-moderno, essas "vozes" passam a funcionar como uma espécie de práxis desenvolvendo um tipo de crítica sócio-política e cultural buscando construir tantas "biografias” quantas forem necessárias para sua autolegitimação. A partir daí, poderemos estudar como o outro e o sujeito da voz identificam-se para (supostamente) preencherem o que falta ser dito. De acordo com Moreiras, "o enunciador do testemunho só pode se tornar 'um de nós' à medida que sinaliza ser primeiramente um outro" (2001, p. 257).

Há, dessa forma, a possibilidade de verificarmos como o sujeito discursivo passa a desestabilizar a significativa rede do que sempre foi comunicado para estender suas posições em exemplos marcantes de novas especificidades discursivas agenciadas por ele mesmo. $\mathrm{O}$ novo significado acompanha o sujeito falante e pode, assim, manifestar-se por meio de linguagens renovadoras. Ainda segundo Moreiras, “A voz que fala no testemunho - estou me referindo à voz testemunhal, e não à voz paratextual do autor ou do mediador - é metonimicamente representativa do grupo pelo qual fala" (2001, p.256).

A importância dessa prática nos levará, portanto, a verificar como os procedimentos utilizados pela enunciação deixam marcas que informam não apenas sobre o sujeito que fala, mas, principalmente, como o povo, o coletivo, sente-se livre para falar sobre sua realidade.

Partindo do pressuposto bastante generalizado de que essas vozes possam referencializar o vasto e variado campo para a constituição dos sujeitos falantes, existe a perspectiva de argumentarmos que esse outro, esse quem, manifesta-se em possibilidades enunciativas e, como consequência, é o produto de um poder considerado o organizador da vida industrializada, da vida urbanizada, globalizada, do nascimento da "família enunciativa" modificadora da história das narrativas. A tudo isso, corresponde um novo tipo de organização do campo simbólico para criar um outro processo de atingir os leitores com seu enfoque. No intervalo, separando rupturas de certas analogias com fenômenos culturais de 
séculos passados e do atual, insere-se o sujeito da fala que explora a metaficção contemporânea, fazendo-se enunciar.

Dessa forma, e em meio a tantas mudanças, o problema de quem fala no texto pósmoderno deixa transparecer o próprio discurso, legitimando-se de acordo com as possibilidades de renovação do literário. Embasado em pressuposições ideológicas, discursivas, emancipatórias e, emocionais, quem fala mostra que todas essas possibilidades prosseguem fora e além dos limites de fronteiras, impondo uma espécie particular de utopia estética testemunhando outras possibilidades.

Assim, proliferam os estudos sociológicos e políticos, além da história cultural, abarcando novos modos de compreensão das construções narrativas. No ilimitado da enunciação, a própria voz da pós-modernidade defende-se da (in)esperada referencialização do "real" extraliterário.

Precisamos visualizar um significado, realizando nosso desejo de compreender as narrativas e as estruturas discursivamente legitimadas, a fim de entendermos as complexas conexões existentes entre o antigo, a tradição e as novas formas de expressão.

Assim, o trabalho marcará a expressividade da chamada "cultura de fronteiras", deixando entrever o aumento do interesse em termos de uma leitura que não vai ao encontro de uma única resposta. Pelo contrário, esta cultura é uma das muitas complexidades nas quais os chicanos encontram-se envolvidos.

A fronteira tem sido, como poderemos verificar, o resultado de uma produção intelectual e artística sistematizadora de obras interdisciplinares de autores como Renato Rosaldo, García-Canclini, Gloria Anzaldúa e Guillermo Gómez-Peña, dentre tantos outros. Gómez-Peña, no ensaio "La cultura fronteriza: um proceso de negociación hacia la utopia", tece considerações a respeito da fronteira ser um "espaço de experimentação" (TORRES, 2001, p. 29). Foi no espaço metropolitano entre Tijuana/San Diego, que Gómez-Peña e um 
grupo de ativistas formado por chicanos, mexicanos e norte-americanos, em 1984, reuniam-se para formar ideias que serviriam para o desenvolvimento de seus trabalhos (TORRES, 2001, p. 29). Desses encontros nasceu a arte performática de Gómez-Peña, constituída por textos sempre "em processo", ["still be in progress"] como o próprio autor afirma (1996, p. III).

Desconstruída a noção de homogeneidade tão defendida pela cultura hegemônica do cânone norte-americano, a inclusão de "literaturas de fronteiras", como a chicana, tem sido efetuada, principalmente, por meio da imposição do espanhol chicano e de suas variantes, tais como o Spanglish, o Tex-Mex e o Caló, em uma forma de mostrar como as fronteiras nacionais foram dissipadas e o domínio de uma única ideologia dispensa a demarcação, evidente ou velada, de muitos outros sentidos.

Os espaços explorados por Gómez-Peña e Anzaldúa, mais que um problema de transculturação ${ }^{3}$, refletem múltiplas realidades trazendo inovações para situar as fluidas fronteiras das Américas, sejam elas geográficas, culturais, econômicas ou qualquer outra. O sentido que emerge de "fronteiras" caracteriza-se, portanto, por marcar a transgressão de transpor limites de gênero (prosa/verso), de linguagens (literária/teatral/dramática), de línguas (inglês/espanhol/francês) etc, além de "gastar o tempo como puro presente e, na esfera da cultura, para consumir os tesouros acumulados pelo alto modernismo" (COSTA LIMA, 1991, p.124). Além do mais, as fronteiras não são apenas uma marca de diferenciação, mas aquelas que garantem a autoridade de se enunciarem, contida na voz do outro.

Desse modo, nosso trabalho será investigar como as estruturas narrativas presentes na "ordem natural" de uma "grande narrativa" cederam lugar a uma estrutura que transgride essa ordem, cujas expressões abarcam diferenciadas manifestações artísticas.

Da mesma maneira, os estudos sobre o hibridismo cultural e social levaram-nos a optar pela escolha do tema do trabalho "O eco da voz chicana". Aqui não negamos territórios, 
assim como não negamos as autonomias escriturais transformadas em não-convenções para mostrarmos que não há um único sistema estético-literário presente nas obras em estudo.

Identificadas essas questões, procuraremos investigar como o lócus que se desdobra por meio das histórias chicanas faz Gómez-Peña e Anzaldúa encontrarem uma nova maneira de escrever a história dos "mestizos", da não-fronteira e das contradições culturais entrelaçadas em um contexto contemporâneo.

Caracterizados pela mistura das línguas inglesa e espanhola, os chicanos são descritos pela luta para romper com as tradições opressivas, pela desconstrução da homogeneidade pretendida por pessoas que fazem uso da mesma prática cultural, da mesma religião, da mesma raça, da mesma língua, e pela luta por uma transculturação culminando em um entrelaçamento de formas em um contexto contemporâneo.

A escolha do tema está centrada, dessa maneira, na relação tensiva de um encontro dialógico entre teorias literárias e estudos culturais para mostrar como uma reflexão sobre estéticas é elemento fundamental quando desejamos abordar os paradigmas críticos do pensamento sobre as alternativas múltiplas do contemporâneo. Para isso, conceitos-chave como identidade, hibridismo, transculturação são fundamentais. Expressando "verdades" por meio de um discurso de adequação, cuja segurança elimina a posição de qualquer sujeito que se queira hegemônico, estes conceitos nos ajudarão a mapear as raízes e os rumos dados pela expressividade chicana, quando se trata de fazer surgir um diálogo entre um emissor e seu leitor.

Embora reconheçamos a literatura chicana como aquela que apresenta uma enorme diversidade de "vozes" enquanto herança cultural, a subjetividade construída pelos autores ajuda a renovar nosso olhar sobre o grupo.

A interação conciliatória das linguagens literária, dramática, poética, pós-moderna, apresenta-se, portanto, como uma espécie de renovação que destaca a força polifônica 
emergente na evolução dessas ideias. O discurso literário figura como contribuição para a mescla de diferentes estéticas originadas da problematização de pensamentos de um sujeito, dito sujeito pós-moderno.

Assim, o embasamento para refletirmos sobre essas ideias parte de leituras a respeito de conceitos literários da pós-modernidade e de estudos culturais, em textos de Néstor Garcia Canclini (1992, 1997, 2003), S. Connor (1992), Guy Debord (2002), Terry Eagleton (1983, 1997, 2000), C. Geertz (1989), Homi K. Bhabha (1998), Stuart Hall (2003), Walter D. Mignolo (2003), Maria Elisa Cevasco (2003), Linda Hutcheon (1991), Fredric Jameson (1992, 1996), Jean-François Lyotard (2002), Carlos Rincón (1995), Silviano Santiago (2000, 2002), José David Saldívar (1997), Lucia Santaella (2003, 2004), Sônia Torres (2001, 2001b.), George Yúdice (2004), dentre outros.

Nosso estudo envolverá, assim, a busca de fundamentos em teorias sobre a pósmodernidade em geral e sobre as estratégias de trabalho dos dois autores em particular, pois Gómez-Peña insere em sua obra, também, o relato das experiências vividas por ele no campo teatral, além de escrever em verso e prosa. De maneira semelhante, Anzaldúa mistura poemas líricos e prosa, mostrando uma posição nada rígida na criação de novas manifestações.

Pela marca do enfoque interdisciplinar, poderemos investigar como a busca por processos de articulação entre um lócus e outro intensificam-se em práticas estéticas trazidas para determinados debates dentro da esfera artístico/literária.

A partir daí, uma outra etapa do estudo consistirá na pesquisa dos princípios de questionamento do cânone literário. Particularizam-se, neste caso, as posições teóricas assumidas por Gómez-Peña e Anzaldúa ante o polêmico trabalho estético e com engajamento político desenvolvido por eles. Recuperando a tradição mexicana, eles lutam para dar voz ao que já foi silenciado no passado. Descartado o estereótipo inicial de que os chicanos são um povo "preguiçoso, ignorante, criminoso potencial, e, portanto, nada digno de confiança" 
(TORRES, 2001, p. 22), eles formam uma "consciência nacional" diferenciada de outros imigrantes que se encontram em terras norte-americanas, e firmam a chegada de uma renovação estética e literária que os caracteriza de forma singular.

Portanto, um dos principais desafios que enfrentamos quando decidimos analisar as transformações ocorridas com determinados grupos sociais é o fato de esses grupos estarem afastados de seu território nativo, suprimidos diante de opressões econômicas, mesmo vivendo em sociedades prósperas e democráticas. Esses imigrantes e seus descendentes parecem não pertencer a nenhuma cultura estando distantes do "real", sentindo-se inseridos em um círculo sem rumo certo, lutando para conseguirem firmar uma identidade. Nesta linha de estudo de movimentos migratórios, este trabalho focalizará a imigração mexicana nos Estados Unidos e a problemática fronteira entre os dois países, uma vez que a cultura chicana tem sido guiada pelo princípio da negação do outro Outro, enfrentando desafios para sua solidificação, e sendo profanada em suas experiências éticas e morais.

Ademais, há discursos que visam representar suas dificuldades em reavaliar sua história. A cultura chicana tem se constituído em uma "bandeira" à luz do debate sócioeconômico, cultural e artístico na contemporaneidade. Entretanto, ela tem se autofirmado como etnia diferenciada e dado preferência a tudo que lhe dá prazer - literatura, música, moda, barrios, enfim, à arte em geral - levando-a, no final, à negação da "voz" hegemônica vinda de outros lugares. Considerando a sua "voz" o ápice de manifestações de mudanças, a cultura chicana constitui importante fórmula de relações para abordar a problemática do limite e da transgressão, utilizando-se do "espaço" da linguagem com essa finalidade. De acordo com Foucault,

o ser da linguagem da literatura moderna é também elisão de sujeito, da alma, da interioridade, da consciência, do vivido, da reflexão, da dialética, do tempo, da memória [...] No momento em que a linguagem escapa da representação clássica e é tematizada como significação na modernidade, a palavra literária se desenvolve, se desdobra, se reduplica a partir de si própria, não como interiorização, psicologização, mas como exteriorização, passagem para fora, afastamento, distanciamento, diferenciação, fratura, dispersão com relação ao sujeito, que ela apaga, anula, exclui, despossui, fazendo 
aparecer um espaço vazio: o espaço de uma linguagem neutra, anônima. $O$ aparecimento ou reaparecimento do ser da linguagem é o desaparecimento do sujeito [...] "quem fala?", recebe a seguinte resposta de Mallarmé: "quem fala é a própria palavra” em seu ser enigmático e precário, no sentido em que "Mallarmé não cessa de apagar-se na própria linguagem, a ponto de não mais querer nela figurar a não ser como executor em uma pura cerimônia do Livro, onde o discurso se comporia por si mesmo". (2001b, p. 115)

Os planos e as decisões de Gómez-Peña e Anzaldúa para "falarem” de si e da etnia parecem vir, dessa maneira, de lugares um tanto quanto condizentes com a própria linguagem, que, por via de estruturas organizacionais, tem se flexibilizado e formado questionamentos ligados a segmentos excêntricos da sociedade hegemônica estrangeira. Para poderem ser a "outra voz" emergente, Anzaldúa e Gómez-Peña assinalam o que deve figurar como descobertas e dimensionam a "voz" cultural em forma de ousadia que interpreta e pergunta sobre o "percurso" percorrido pelo chicano durante quatro séculos. Além disso, atacam os princípios vigentes como valor, sentido, ordem, controle, premissas básicas do poder do opressor.

Muitos intelectuais apontam como chave explicativa para esse fenômeno, o fato de Gómez-Peña e Anzaldúa se questionarem sobre a capacidade de criarem laços no lugar em que vivem, os Estados Unidos da América, para assim, trabalharem com eficiência na recuperação de suas tradições. Pode-se sustentar que a história desse resgate aponta o caminho de uma superestimação idealizada da "consciência mestiza", termo usado por Anzaldúa quando se remete à principal tarefa enfrentada por eles: a ativação de um sentimento nacional ligado a uma tradição histórica. Essa exigência coloca-os diante da discussão e da apresentação da literatura (chicana) e da "vida real" como abertura de um espaço para articularem um ponto de vista a partir do qual a quase totalidade da vida sóciocultural e artística pode ser avaliada e estudada. Talvez tenham sido as limitações a eles impostas, a chave para abrirem novas portas para formarem as relações entre criações sociais, estéticas e ideológicas. Segundo Canclini, 
O mundo moderno não se faz apenas com aqueles que têm projetos modernizadores. Quando cientistas, tecnólogos e empresários buscam seus clientes, eles têm também que lidar com a resistência à modernidade. Não apenas pelo interesse em expandir o mercado, mas também para legitimar sua hegemonia, os modernizadores precisam persuadir seus destinatários de que - ao mesmo tempo que renovam a sociedade - prolongam tradições compartilhadas. Posto que pretendem abarcar todos os setores, os projetos modernos se apropriam dos bens históricos e das tradições populares. (1997, p. 159)

Ao situar essa condição, Anzaldúa e Gómez-Peña estão relacionando as práticas chicanas tradicionais a seus processos de representação para se legitimarem na atualidade. Os autores intencionam mostrar que esta não é uma prática ingênua, senão a maneira como eles escolheram para sua afirmação como cultura legítima, autônoma. Gómez-Peña e Anzaldúa têm logrado ver em suas artes elementos de um processo artístico que remete não apenas a um reinado de uma ideologia própria, das artes ou das ideias. Eles têm intentado especificar as próprias condições artístico-culturais.

Recuperar a tradição para Anzaldúa e Gómez-Peña é, portanto, não desconhecer o desenvolvimento próprio de uma arte (popular), uma pluralidade de significativos aspectos autônomos, utilitários, de exame das reestrurações das formas clássicas artísticas. Recuperar a tradição é trazer à baila os bens populares, é redimensionar, dentro de uma lógica comunicacional, os valores do passado em relação a uma sociedade mais global, mais associada a identidades unidas para enfrentarem desigualdade de poder, de prestígio e de recursos financeiros do presente. Recuperar a tradição para Gómez-Peña e Anzaldúa é visualizar o ilimitado das ideias dominantes de seu tempo e de uma tradição asteca; é relacionar uma história social do passado a condições de produção cultural do momento; é pressentir uma natureza ou um lugar da linguagem em que se reconhecem elementos de uma superestrutura que soma "realidade" e arte. E, assim, ao escrever sobre essas contradições pós-modernas, Anzaldúa expressa o seguinte:

E alguém em mim dá importância a nós mesmos, e, no final das contas, domina sobre as serpentes sobre meu próprio corpo, minha atividade sexual, minha alma, minha mente, fraqueza e força. Meus. Nosso. Não dos homens heterossexuais brancos, ou de cor, ou do estado, da cultura, da religião ou dos pais - apenas nosso, meu. 
E, de repente, sinto tudo convergindo para um centro, um núcleo. Todos os pedaços perdidos de mim vêm voando dos desertos, montanhas e vales, magnetizados em direção àquele centro. Completa.

Algo pulsa em meu corpo, uma pequenina coisa luminosa que cresce mais forte a cada dia. Sua presença nunca me abandona. Nunca estou só. Isso é que importa: minha vigilância, os milhares de olhos das serpentes luzindo na noite, sempre abertos. E não estou com medo. $(1999, \text { p. } 73)^{4}$

As inquietações também estão expressas nessa afirmação de Gómez-Peña:

GP \& RS: (num ritmo sincopado): A passagem do Terceiro para o Primeiro Mundo, do passado para o futuro, lembra-se? A cruz, a borda, o abismo, o sismo, a patrulha de fronteira, a inter-conexãoweb, as câmeras de TV, minhas velhas performances, seus velhos preconceitos, a migração original, [...] Lembra-se?

ESCURIDÃO. (1996, p. 41)

Recuperar (e preservar) a tradição para os autores é, como podemos ver, a necessidade de eles a manterem justaposta às formas renovadoras da atualidade para poderem apoiar umas nas outras. Com frequência, Gómez-Peña e Anzaldúa quebram formas artístico-culturais ou deixam tensões explosivas alojarem-se no interior de seus textos. Já não se pode imaginar que os "textos" artísticos e literários dos autores, ao enfocarem o passado, permaneçam vazios de comunicação ou não sejam ocupados com elementos imprevistos da modernidade. Nesta afirmação dos valores tradicionais no mundo contemporâneo, Maria Elisa Cevasco aponta que “o que sobrevive da tradição cultural sobrevive a despeito dos 'meios de produção' em mutação cada vez mais rápida" (2003, p. 36).

Para Gómez-Peña e Anzaldúa, portanto, a tradição foi e é recuperada quando puderam confrontar e reescrever sua história a partir do cânone das grandes obras de poesia e romance. Eles perceberam que podiam dar "vivas à diferença" e colocar abaixo o universalismo canônico convencionalizado para manter uma nova "ordem" nas disputas entre as diferentes identidades nacionais, étnicas ou globalizadas. Os autores puderam perceber que, naquele momento, estavam acabando com a neutralidade e a "inocência" que se supunha a respeito deles. Eles tinham estreitado, por essas medidas, "a noção do político, reduzida agora a uma prática cultural e à defesa do particularismo de diferenças culturais" (CEVASCO, 2003, p. 25). 
Sendo assim, durante suas atuações e contradições, Anzaldúa e Gómez-Peña encontraram forças para desenvolver diferenças simbólicas próprias, alterações bruscas, renunciando e quebrando antigas normas canônicas. O fundamental era, então, questionarem sobre o pertencimento a uma diferença, a uma nova produção de sistemas das relações artístico-sociais. O novo alvo, depois de recuperarem a tradição, seria obter uma posição que se contrapusesse às normas dominantes do estruturalismo canônico. Ora, eles não podiam adotar o mesmo posicionamento, atuarem nas mesmas práticas.

A "virada" marcou um momento único, privilegiado por uma maneira de escrever capaz de renovar antigos valores, genericamente mais "humanos". Julgamentos do passado têm sido a base e a consequência para eles debaterem sobre a cultura chicana recebida como linguagem carregada de um sentido inerente aos padrões da "fala" chicana. Como minoria marginalizada, já são capazes de relatar não somente um passado significativo, mas de mudar, também, alguns aspectos mais sutis e mais frágeis dos padrões implícitos na própria cultura. As estruturas estilísticas de Anzaldúa e de Gómez-Peña têm sido marcadas por inovações, mas elas são a essência para mostrarem um passado, segundo eles, glorioso, sobrevivendo às mudanças.

O interessante é podermos perceber como os autores deixaram a condição marginal para poderem incorporar os valores culturais ao representarem uma nova história. O fato de eles mostrarem novas tendências nessas "localidades" anônimas, tem feito os autores revelarem o campo em que podem apresentar uma outra esperança para quebrar resistências. A situação teórica e política de ambos tem marcado a atuação desses seus movimentos que, embora não homogêneos, congregam comunidades dissidentes, assim como ideais socialistas independentes. É algo parecido com a criação de uma interação complexa de sentimentos compartilhados, transgressões arquitetadas ao modelo de determinadas tendências de provocações comuns. Segundo Foucault, a transgressão 
é um gesto relativo ao limite: é aí, na tênue espessura da linha, que se manifesta o fulgor de sua passagem, mas talvez também sua trajetória na totalidade, sua própria origem. A linha que ela cruza poderia também ser todo o seu espaço. O jogo dos limites e da transgressão parece ser regido por uma obstinação simples: a transgressão transpõe e não cessa de recomeçar a transpor uma linha que, atrás dela, imediatamente se fecha de novo em um movimento de tênue memória, recuando então novamente para o horizonte do intransponível. Mas esse jogo vai além de colocar em ação tais elementos: ele os situa em uma incerteza, em incertezas logo invertidas nas quais o pensamento rapidamente se embaraça por querer apreendê-las.

O limite e a transgressão devem um ao outro a densidade de seu ser: inexistência de um limite que não poderia absolutamente ser transposto: vaidade em troca de uma transgressão que só transporta um limite de ilusão ou de sombra. (2001, p. 32)

Assim, demorou algum tempo para que a nova maneira (politizada) de escrever de Anzaldúa e Gómez-Peña fosse estabelecida como objeto de discussão. Mas, a partir daí, escrever sobre a "vida real" em forma de literatura, abriu espaço para que eles articulassem de um outro ponto de vista a vida chicana que podia, agora, ser avaliada. Tão difundidos estão os valores de seu grupo que suas "vozes" já fazem parte de disciplinas acadêmicas institucionalizadas. Anzaldúa e Gómez-Peña criaram uma forma para serem lidos; puderam constituir um sentido para os exercícios de leituras a fim de que seus valores sejam visualizados. Eles têm permanecido fortes nas concepções de quebrar resistências. Tanto um quanto o outro, agora são o diferencial dos estudos da cultura chicana. Eles participam daquilo que pode ser chamado "reconceitualização" de uma cultura, visto sob o ponto de vista de discursos coletivos. Segundo Gómez-Peña,

\begin{abstract}
A América não é mais o continente que você imaginava [...] Áudio-grafite, FM, buscando uma nova linguagem para expressar seus temores e desejos interculturais [...]

Nos bairros de resistência - versões contemporâneas dos velhos quilombos - cada quarteirão tem um centro comunitário secreto. Lá, os jovens fugitivos chamados Raça-Robô II ou "população flutuante" publicam revistas anarquistas xerocadas a laser, editam vídeos caseiros experimentais sobre a brutalidade policial (sim, a brutalidade policial ainda existe) e transmitem intervenções de rádio pirata como esta sobre os programas mais populares da Rádio oficial Nova Ordem. $\left(1996\right.$, p. 38) ${ }^{6}$
\end{abstract}

Trata-se, portanto, de apreendermos o que Gómez-Peña e Anzaldúa articulam sobre os novos aspectos da ritualidade chicana no cotidiano. Conforme sua constituição histórica, também podemos identificar que eles não ignoram o valor de se comemorar as convenções 
tradicionais, como a Virgem de Guadalupe, admitida como modelo de renascimento de uma nova etnia.

Sendo assim, esse particular é a diferença fundamental para os chicanos se firmarem como grupo, e concretizarem relações sócio-culturais tão complexas. Anzaldúa e GómezPeña, com suas lutas políticas e sociais, retratam uma sociedade com uma intensa força produtiva contestadora do domínio hegemônico a fim de mostrar a própria importância na produção de uma outra ordem cultural. Eles têm desenvolvido as chaves que demonstram a função cotidiana da vida chicana entrelaçada em mitos fundantes de celebração da etnia. Suas contribuições vão do histórico ao artístico, do tradicional ao moderno, do culto ao popular, mas o novo perfil artístico cultural erigido por eles revela a expansão da estética chicana nascida de um antigo patrimônio cultural entrelaçado ao moderno. Os autores veem o fim dos poderes centrais como saída para as problemáticas oposições masculino/feminino, branco/negro, pobre/rico e outros binarismos.

A fim de criarem espaços próprios e mostrarem sua importância, os autores têm testemunhado um retrato quase fiel da realidade. Eles aliam a história às teatralizações do cotidiano, jogam com determinadas operações linguísticas a partir das quais lidam com a alteridade; ampliam suas escrituras incluindo o popular. Além disso, também exibem e afirmam os limites para o étnico. Senão vejamos o que nos retrata Gómez-Peña:

Tá legal ... Desde o momento em que o mercado artístico implodiu, os artistas não são mais necessários como aqueles que constroem imagens. A maioria deles trocou o fazer artístico por métiers mais úteis. Eles têm se tornado estudiosos de fronteiras, especialistas em cruzar fronteiras, piratas midiáticos, e diplomatas transculturais. De fato, muitos deles colaboram em segredo com a Raça-Robô II. (1996, p. $39)^{7}$

Esse fragmento torna-se curioso para vermos o quanto os autores representam sua diferença e sua importância como artistas. Na verdade, a mistura de gêneros abordada em suas obras demonstra como eles têm contatado a realidade chicana e testemunhado a dominação estrangeira como apropriação injusta de um "espaço territorial” e de um tempo histórico que 
lhes pertenciam. Com isso, Gómez-Peña e Anzaldúa produzem valores, outras identidades, distintos dos setores hegemônicos do Outro para, assim, poderem pensar essas questões do ponto de vista da desigualdade e criar uma outra forma de literatura desafiadora do cânone.

Os produtos gerados daí constituem, nesse sentido, todo um patrimônio próprio. Gómez-Peña e Anzaldúa alcançam um valor estético, criatividade, tolerância, processados de maneira sofisticada, formalizados em produtos culturais. Marcam a literatura pós-moderna mostrando sua força como grupo por meio de manifestações artísticas. Eles renovam a multiplicidade de imagens nas manifestações dos bens simbólicos para inscreverem um domínio dentro da sua própria ideologia. Então, como não podia deixar de ser, eles transferem a alienação que sempre os ameaçou, para um novo instrumento de descoberta de afirmação, a literatura chicana. Desse ponto, interpretam o mundo.

O que Gómez-Peña e Anzaldúa ganham com esse poder descritivo de intervenção é a prática de pensarem a tradição e renová-la artisticamente, substancializando a formação de uma $R a z a^{8}$. Segundo Canclini,

O arcaico é o que pertence ao passado e é reconhecido como tal por aqueles que hoje o revivem, quase sempre "de um modo deliberadamente especializado". Ao contrário, o residual formou-se no passado, mas ainda se encontra em atividade dentro dos processos culturais. O emergente designa os novos significados e valores, novas práticas e relações sociais.

As políticas culturais menos eficazes são as que se aferram ao arcaico e ignoram o emergente, porque não conseguem articular a recuperação da densidade histórica com os significados recentes gerados pelas práticas inovadoras na produção e no consumo. (1997, p. 198)

Assim, ao traçar seus percursos, os autores parecem compreender o funcionamento da antiga hegemonia e de se oporem a ela, criando o que consideram a sua própria forma de expressão. Isso mostra que os textos, tanto de Anzaldúa quanto de Gómez-Peña, são o resultado de combinações em constante renovação. Isto é, a escritura de ambos é o produto de uma imaginação para representar uma forma que permita a nós, leitores, "ver", "escutar" e “compreender" a realidade chicana. Nesse sentido, a ligação entre conteúdos políticos e arte fica cada vez mais evidente em seus empreendimentos. 
Essa configuração significa que refletir sobre a vida, para eles, restaura e difunde a contextualização que os firmará como Raza, aquela tornada inteligível pelo fato de ter produzido um conhecimento político, científico, artístico e cultural. Nesse processo, eles encararam cadeias opositoras confrontando outros valores, mas articularam alicerces que têm resistido a todo tipo de enfrentamento. Mais do que qualquer coisa, aos autores interessa legitimarem-se como a nova força de poder, aquela que incomoda, porém ocupa um lugar em que são reconhecidos: a Raza, produzindo sentidos, objetos e conceitos; a Raza trabalhando para colaborar com uma outra consciência, bastante evidente.

A opressão que os chicanos sofreram, hoje reflete-se em um outro "estado" de coisas identificado como a nova Raza. Efetivamente, a expressão "Raza" dá a entender a correlação, na cultura chicana, entre domínios de saber, determinados tipos de normatividade, assim como formas de subjetividades que os identifica como outra linguagem, independente do sujeito que fala. As obras escapam da única história autêntica, e apontam para verdades plurais.

\section{NOTAS}

1- O termo chicano tem sido usado para nomear a descendência indígena asteca/mexicana depois da explosão colonizadora empreendida por Hernan Cortez ao México. Embora os primeiros usos do termo tenham cunhado um sentido discriminatório, esses descendentes indígenas desenvolveram uma "consciência nacional" que lhes permite anunciar a existência de uma nova nação, - uma Raza, como eles dizem -, de culturas, e de economias estruturadas por lutas sociais e políticas que os diferenciam de seus vizinhos latinos. O chicano reflete uma identidade cultural e social, tanto quanto artística, únicas. Ao denunciar aquele colonizador e os últimos ataques sofridos por angloamericanos, esse povo procura criar novas fronteiras para livrá-lo da conotação de ser pobre, preguiço, ignorante, e criminoso.

2- A literatura que vem sendo chamada de "chicana" é composta por histórias de luta empreendida por mexicanos americanizados, e que se constitui em uma tentativa de dizer como o transnacionalismo pode se tornar local e vice-versa, e como mundos tão separados pela distância podem se unir na afetividade. Considera-se que a literatura chicana teve início já no século XVI quando o explorador espanhol Álvar Núñes Cabeza de Vaca, depois de ter convivido com grupos indígenas onde hoje é o Sudoeste dos Estados Unidos e o norte do México, escreveu um relato sobre sua permanência naquele lugar, publicado em 1542. Na atualidade, a literatura chicana expressa não apenas a cultura chicana, mas, também, a maneira como essa etnia conquistou uma língua (o espanhol chicano) para demonstrar os interstícios sociais entre o México e Estados Unidos. A literatura chicana, além de tudo, direciona seu foco sobre temas compreendendo a formação de diferentes identidades, sobre a 
desagregação social em consequência da discriminação sofrida, sobre as experiências históricas, e para fundamentar todo um trabalho voltado para o reconhecimento dos chicanos como nação, como povo. (SALDÍVAR, 1991)

3- Analisando as obras de Gómez-Peña e Anzaldúa, não há como não nos determos e pensarmos sobre o termo transculturação. Empregado pela primeira vez por Fernando Ortiz em sua obra Contrapuento cubano del azúcar y del tabaco, de 1940, transculturação produz um jogo simbólico de forças semânticas a fim de enunciar o que resulta quando se adquire uma nova cultura (aculturação); o que se perde ou o que se desliga de uma cultura precedente (desculturação); ou o que se cria quando se formam novos fenômenos culturais (neoculturação) (REIS, 2005, p. 467)

4- "And someone in me takes matters into our own hands, and eventually, takes dominion over serpents - over my own body, my sexual activity, my soul, my mind, my weaknesses and strengths. Mine. Ours. Not the heterosexual white man's or the colored man's or the state's or the culture's or the religion's or the parents' - just ours, mine.

And suddenly I feel everything rushing to a center, a nucleus. All the lost pieces of myself come flying from the deserts and the mountains and the valleys, magnetized toward that center. Completa.

Something pulsates in my body, a luminous thin thing that grows thicker every day. Its presence never leaves me. I am never alone. That which abides: my vigilance, my thousand sleepless serpent eyes blinking in the night, forever open. And I am not afraid". (ANZALDÚA, 1999, p. 73)

5- “GP \& RS: (in syncopated rhythm) The crossing from the Third to the First World; from the past to the future, remember? El cruce, el bordo, el abísmo, el sismo, la migra, the spiderweb, the TV cameras, my old performances, your oldest prejudices, the original migration,... Remember?

BLACKOUT” (GÓMEZ-PEÑA, 1996, p. 41)

6- "America is no longer the continent you imagine [...] Audio-graffiti, FM, buscando un Nuevo lenguaje para expresser sus temores y deseos interculturales[...]

In the barrios of resistence - contemporary versions of the old kilombos - every block has a secret community center. There, the runaway youths called Robo-Raza II or "floating greasers" publish anarchist laser-xerox magazines, edit experimental home videos on police brutality (yes, police brutality still exists) and broadcast pirate radio interventions like this one over the most popular programs of the official Radio Nuevo Orden”. (GÓMEZ-PEÑA, 1996, p. 38)

7- "Okay... Since the art market collapsed, artists are no longer needed as image-makers. Most of them have traded making art for more useful métiers. They have become borderólogos, experts on border-crossing, media pirates, and cross-cultural diplomats. In fact, many of them collaborate in secret with Robo-Raza II”. (GÓMEZ-PEÑA, 1996, p. 39)

8- Segundo Anzaldúa, os chicanos tinham uma tênue percepção sobre o que era ser um povo até que em 1965, fazendeiros e César Chavez se uniram, nasceu no Texas o partido da Raza Unida e publicou-se Eu sou Joaquim. Os chicanos se reconhecem, a partir de então, como um povo distinto. A autora afirma, também, que eles acordaram para a própria realidade e adquiriram um nome e uma língua (o chicano-espanhol), refletindo essa realidade. Os pedaços fragmentados que os formavam como, quem eram, o que eram, como estavam envolvidos com a nação, começam a cair e percebem no que tinham se tornado $(1999$, p. 85). 


\section{CAPÍTULO I}

\subsection{O significado de ser chicano/a expresso por meio de vozes literárias}

Analisar qualquer aspecto da identidade chicana hoje em dia é parte de um eixo histórico-cultural que situa a etnia em uma representação espaciotemporal equivalente a uma relação direta entre um discurso das vivências pessoais e acontecimentos imagéticos do passado.

A partir do amplo espectro de campos artísticos de onde a criatividade chicana toma seu "território" singular (literatura, cinema, música, barrios, muralismo, etc), vários são os

temas que têm sido objeto de interpretação, composição e representação dessa mestiçagem ${ }^{1}$ cultural. Quando e onde começa a ênfase dada em conhecer suas origens, é motivo para se construir a imagem entre a emergência de uma raça e os usos discursivos que avaliam as mudanças ao longo do tempo.

Os estereótipos sociais, o racismo enfrentado pelos chicanos em território norteamericano, e o machismo de sua própria coletividade têm sido motivo de representação, para a literatura chicana.

Ser chicano, em um primeiro momento, como teremos oportunidade de examinar nas obras Borderlands / La Frontera: The New Mestiza (1999), de Gloria Anzaldúa, e The New World Border (1996), de Guillermo Gómez-Peña, é viver uma "realidade” em um grupo bicultural (mexicano e norte-americano) do mesmo modo que é conceber ideias pressupondo uma diversificada força de criação poética em um eixo multicultural. A coletividade chicana é produtora de concepções, ideais e atividades que a situam em determinadas condições para desenvolver suas forças artístico-literárias com múltiplos intercâmbios sócio-culturais. Para aquela coletividade, pensar sobre tudo isso significa ouvir e interrogar, combinar 
experimentos, ter um posicionamento ideológico. Assolada por um mundo opaco de objetos, a consciência resultante desses enfrentamentos não podia ser outra coisa senão a consciência de um processo de vida "real", reconhecido nas raízes raciais do mexicano-estadunidense contemporâneo. Segundo Benavidez,

Como o mexicano nascido e criado ao sul da fronteira México-Estados Unidos, o mexicanoestadunidense é um mestiço - um híbrido racial que não é índio, embora tenha vindo dele; que não é espanhol, embora seja da Europa. No que concerne às raças, a raça mestiça - conhecida em certas ocasiões como a raça cósmica - com seu meio milênio de idade, é bastante jovem. (MAX BENAVIDEZ, disponível em <http://www.zonezero.com/magazine/essays/distant/zmonta.html>). Acesso em: 17.fev.2009.

Ser chicano, então, é ter podido manter, como minoria, uma "vida" associada a conhecimentos dos aspectos cotidianos do passado, assim como um interesse que traça contribuições literárias e sociais relevantes à construção de princípios figurativizados de caráter. Diferentemente de muitos negros, os chicanos, tanto quanto os índios dos quais descendem, mantém viva a língua de seus ancestrais mesmo estando em contato com a cultura branca (euro)norte-americana. Eles adquiriram um sistema próprio de linguagem que os coloca de forma definitiva dentro de projetos globais de entendimento.

Historicamente, o chicano origina-se de um povo que tem ocupado o mesmo território por mais de 300 anos com a diferença de passar seus direitos de colonizadores a colonizados, ou seja, o chicano atual é o produto resultante de uma longa jornada e um extenso período de ocupação e de colonização. E, sem dúvida, seu passado, sua língua e sua cultura são os ideais que mantêm esse grupo conectado com as faculdades de sustentação de uma identidade diferenciada da dos brancos da América do Norte.

O termo chicano começou a ser utilizado nos Estados Unidos da América há pelo menos 30 anos quando, para um segmento da população de origem hispânica vivendo em território norte-americano, foi usado para declarar os cidadãos norte-americanos de origem mexicana ou mexicanos radicados nos Estados Unidos. 
Em sua origem, o termo era usado de forma pejorativa para designar uma cultura relegada às margens, humilhada pela colonização espanhola, mas que, a partir das décadas de 60 e 70 do século XX, durante o Movimento Chicano, passou a conotar, pela sociedade branca e pela própria comunidade, os mexicano-americanos engajados na luta por igualdade social.

Por volta daquela época, o grupo deu início a uma prática de mudanças sociais e políticas assinalando uma trajetória marcada por reformas extremamente radicais na sociedade. De suas variadas atividades e ideias específicas, emergiu uma nova consciência política cuja militância uniu as pessoas para lutarem por diferentes causas comuns à sua coletividade. O movimento ficou conhecido como chicanismo e marcou a maneira de os mexicano-americanos pensarem sobre si mesmos, de se entenderem, pela primeira vez, como uma comunidade com um passado e um presente.

Desde então, eles têm reinterpretado seu passado e o tem relacionado à própria história, permitindo aos chicanos descobrirem seu legado de lutas. Organizados, os chicanos, atualmente, podem resistir aos ataques de outras culturas.

Por outro lado, se não levarmos em conta o pano de fundo da independência précortesiana, uma vez que se trata de um período histórico conhecido como um semimito, podese afirmar que "desde 1520 até o presente, isto é, por mais ou menos 450 anos, o indivíduo ou grupo chamado mexicano-chicano não tem conhecido um momento de independência ou autonomia sócio-política. Esses 450 anos de subjugação deixaram suas marcas duradouras” (JUSTOS ALARCÓN, disponível em $<\underline{\text { http://www.cervantesvirtual.com/servlet/Sirveobras/chic/1225163102015938421435/p00 }>) . ~}$ Acesso em: 24.abr.2009.

O importante para nós, então, será sustentar as circunstâncias de representação do espaço discursivo da criação da identidade chicana como aquela que se refere e se mantém no 
tripé "geográfico" da terra mítica de Aztlán (leia-se "tradição"), o barrio urbano, e a fronteira (que separa o México e os Estados Unidos da América).

De maneira ideológica e recuperado durante a década de 60 pelo Movimento Chicano, Aztlán tem se mostrado como o espaço mítico-imaginário, "materializado" em uma combinação de vozes pela maioria dos chicanos, pois, por uma razão ou outra, eles sempre se viram privados e desprovidos de uma terra natal. Entretanto, agora, precisariam de um produto para efetivar a consciência coletiva e organizar uma forma de se legitimarem como uma "nação". O "Plano Espiritual de Aztlán" criado em 1969, de uma forma ou de outra, ofereceu ao domínio público chicano a criação de uma consciência comum enfatizando a recuperação de um espaço a-histórico e utópico, cuja atualidade concreta existiria somente nos corações, nas crenças, poemas de certos cidadãos mexicano-americanos, e nos murais nos quais poderiam se lembrar como elucidação de um povo.

De acordo com Acuña (1998), a palavra Aztlán foi identificada pela primeira vez pelos missionários espanhóis que aportaram no México no século XVI. Sendo assim, a tradição asteca estava toda baseada na origem do povo em Aztlán, uma pátria que ficava mais ou menos ao norte da atual Cidade do México e que era chamada de Tenochtitlán. Trata-se, em outras palavras, de reconhecermos mais recentemente, que esta terra é a região que o México cedeu aos Estados Unidos pelo Acordo de Guadalupe Hidalgo, em 1848.

De forma interessante, o termo Aztlán tornou-se popularmente conhecido em 1969 quando, ao ser elaborado o "Plano Espiritual de Aztlán", foi conferido a ele a defesa e a unificação dos chicanos e a sua autodeterminação ideológica e cultural.

Ainda segundo Acuña (1998), o "Plano Espiritual” teve condições de reabilitar a palavra chicano. Se antes ela tinha um sentido pejorativo, agora, trazia em si o orgulho e o interesse de suas origens, o universalismo do caráter próprio e a cultura única diferenciada dos mexicanos e dos mexicano-americanos nos Estados Unidos. 
$\mathrm{Na}$ verdade, o chicanismo chega a ser mais dinâmico, abrangente e influente do que o movimento de conotações laborais de César Chávez que tinha, também, a intenção de conquistar e unificar os trabalhadores agrícolas mexicanos e mexicano-americanos. Com esse enfoque, podemos falar sobre a importância dessa personagem. César Chávez foi um dos líderes que conclamou e organizou os fazendeiros mexicanos para defenderem seus direitos de posse em um movimento conhecido como Chicano Movement, na década de 60 do século passado. Tendo recebido também o nome de El Movimiento, esta era a luta pela restauração dos direitos de posse da terra usurpada, pela escolaridade dos cidadãos, pelo direito político de voto, tanto quanto pela formação da consciência histórica chicana (disponível em

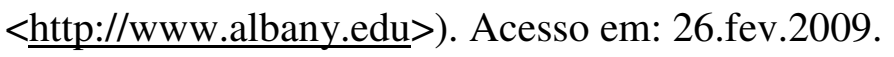

Assim, por uma hegemonia prática e notável, Aztlán tornou-se a bandeira de luta pelos direitos civis plenos de cidadania chicana, além de unificar, através dos tempos, essa minoria étnica nos Estados Unidos.

De qualquer forma, se esses conceitos expandiram e enriqueceram a noção de identidade chicana, também tornaram possível iniciar o desenho de um corpo material e um gume político cultural referencializando cada um dos chicanos. Sua ideologia na formação do povo vai mobilizar ideias no sentido de tornar verdadeiras as crenças nessas questões. Diferentes estudos têm interpretado e concretizado estes movimentos como formadores de qualquer nação. Segundo Bhabha,

O povo não é nem o princípio nem o fim da narrativa nacional; ele representa o tênue limite entre os poderes totalizadores do social como comunidade homogênea, consensual, e as forças que significam a interpelação mais específica a interesses e identidades contenciosos, desiguais, no interior de uma população. O sistema significante ambivalente do espaço-nação participa de uma gênese mais geral da ideologia em sociedades modernas, [...] ao mesmo tempo interior e exterior ao sujeito falante, que fornece a analogia mais apta para se imaginar a estrutura de ambivalência que constitui a autoridade social moderna. (1998, p. 207) 
Assim, frente a um Aztlán idealizado e perdido, contrapõe-se a segunda realidade do tripé da identidade chicana legitimamente empírica denominada barrio. Ele vai se referir à vida da comunidade nos centros urbanos.

Os limites ambíguos nascidos entre o campo que os chicanos ocupavam e a cidade que os representa, agora, como modernidade, faz registrar no barrio o choque cultural enfrentado pelo chicano, uma vez que este, durante tanto tempo um ser rural por excelência, se vê, do dia para a noite, vivendo em condições urbanas e cosmopolitas, experienciando os “deslocamentos", devido aos projetos de renovação, expansão e emancipação das cidades. O problema não estará na forma como terão se modernizado, mas na maneira desigual com que esses elementos vêm se manifestando. De acordo com a própria Anzaldúa, "nos anos 50 eu vi a terra sendo retalhada em milhares de pequenos retângulos e quadrados limpinhos, irrigados constantemente" ["In the 1950s I saw the land, cut up into thousands of neat rectangles and squares, constantly being irrigated".] (1999, p. 31).

Durante todo o processo de identificação, esses barrios têm passado por transformações culturais profundas. Os chicanos desenvolveram, nesses lugares, suas formas de sobrevivência constituindo, com o passar do tempo, uma forma social, política e cultural de ajuda mútua para prestar socorro e conceder benefícios para os desempregados, e o sistema era mantido devido ao respeito existente entre os chicanos. As relações nascidas daí se tornariam férteis e delicadas, além de solidificadas por uma ideologia de constituição grupal. Ali, todas as pessoas, uma a uma, reconheciam os desafios a serem enfrentados coletivamente.

Segundo Torres (2001), os barrios são lugares onde os amigos tanto podem ter experiências positivas quanto negativas. Trata-se do local em que os habitantes podem falar espanhol ou inglês, ao mesmo tempo que serve de refúgio para os pobres e marginalizados (pessoas "separadas" em consequência da pobreza, segregação e discriminação). Os barrios 
são, ainda, caracterizados por habitações pobres, tráfico de drogas, perseguições policiais e mortes, distribuição desigual de benefícios, coexistência de tradições e crenças modernas.

Entretanto, o barrio também é o local onde os mexicanos músicos, cantores, artistas performáticos, bailarinos puderam encontrar uma plateia ansiosa pelas apresentações e por viver as relações de suas condições sociais. É também a defesa da autonomia regional frente às artes transnacionais.

Esse é o resultado das importantes diferenças sócio-econômicas que deram origem a uma arte integrada e firmada nos espaços marginais, mas econômica e assumidamente assimilada no paradigma da resistência cultural, $O$ Teatro Campesino $^{2}$. Devido à intensa capacidade de se renovar incorporando novas tecnologias, as novas regras circulam e se processam nos bens simbólicos de toda condição moderna.

Ao que tudo indica, o interesse dos artistas chicanos em mostrar sua arte se dá a partir desses movimentos de nacionalismo cultural do final da década de 60. Qualquer programa cultural, a partir de então, sublinha tanto a vasta separação quanto a unificação existentes entre as várias correntes artísticas que apareceram depois. Com a nova linguagem artística, bairros inteiros foram "recuperados" para servirem de motivo de reflexão da dupla condição que caracterizou os chicanos: a de antigos ruralistas e, depois, os modernos cidadãos urbanos.

Com isso, um forte elemento da (re)construção de um discurso da identidade (cultural) chicana surge com os chamados espaços pós-modernos. Gómez-Peña, por exemplo, por meio de sua La Pocha Nostra ${ }^{3}$ explora as diferentes "realidades" chicanas em todo um determinado cenário de desigualdades. Ele transforma sua obra a todo momento e, nessa prática, escolhe discutir o que deve ser feito em prol da etnia.

A circulação da identidade chicana surge, como podemos perceber, nesses novos traços que estão, de maneira irreversível, solidificados na tríplice manifestação da tradição 
(leia-se Aztlán), da urbanização (os barrios ), e da fronteira que, amiúde, contribuem para a ênfase polifônica transcendendo a palavra.

Sendo assim, a terceira "realidade" do tripé, a fronteira, apresenta um processo a ser explorado. Ela não podia deixar de ser analisada, pois, em grande parte das obras tanto de Anzaldúa quanto de Gómez-Peña, é ela, a "fronteira" que resume todo tipo de "deslocamento" para se conceber domínios como afirmações de "exterioridades" (em relação a qualquer outra coisa). É em torno dela que se apontarão tantos outros caminhos a serem seguidos.

Uma vez que os interesses da nova mestiçagem chicana despontam como força válida para políticas revolucionárias, o presumível é não se ignorar o Outro, os do "lado" de lá, mas haver uma comunhão de conhecimentos, um desvinculamento das antigas condições conflitantes para se poder abarcar os opostos. Como não podia deixar de ser, estes cortes são concedidos pela "fronteira". A multiplicidade de elementos que, em um primeiro momento, estava ancorada em antigas operações cotidianas, passa a ser identificada como uma nova ideologia, um novo fator: a(s) fronteira(s) e sua transposição.

A fronteira é reconhecida como a categoria de diversidades construída ao longo de uma realidade cultural e de seus momentos de entrave. Ela é o outro e o seu poder de significar o próprio discurso institucionalizado e disponível às formulações das grandes teorias. Fronteira é a relação de domínio em um espaço de poder mediador entre esta metáfora e aquele conhecimento teórico. Ela é, ainda, os efeitos da diferença, a eficiência da disciplina e a certeza da construção de diferentes vantagens aguçando todo tipo de signo da sociedade artístico-literária (e civil).

A fronteira é, por outro lado, o agente ativo que opõe o histórico ao mítico, o dócil à condenação, o mediador à desconstrução (de valores). A fronteira é, sem sombra de dúvida, o poder-saber, o poder-fazer das primeiras transformações sócio-culturais. É ela que reforma os costumes, que concede ao habitante do lugar a noção de identidade pessoal representando o 
ilimitado. Segundo Bhabha, "é vivendo na fronteira da história e da língua, nos limites de raça e gênero, que estamos em posição de traduzir as diferenças entre eles, numa espécie de solidariedade" (1998, p. 238).

Anzaldúa e Gómez-Peña puseram seus talentos no trabalho com esse poder de opiniões surgido nas últimas décadas. Com suas obras, os autores questionam os acontecimentos nessas "áreas fronteiriças" de escuridão à procura de esclarecimentos, sugerindo mudanças constantes de estado.

Sendo assim, Anzaldúa e Gómez-Peña qualificam ou não aquilo que é estável e unitário existente na fronteira, e aquilo que é mutável e desconhecido para a comunidade chicana. Eles partem de um conceito hierárquico de poder colonial e mostram uma intervenção consciente como sujeitos presentes no evolucionismo histórico e político da sociedade. Eles articulam, em seus textos, a inteligibilidade nacionalista, as estratégias em examinar a presença chicana em solo norte-americano, como também o contexto total das instituições de poder. Os autores operam na razão dialética desses fenômenos, reconstruindo o todo cultural dinâmico, sempre em desenvolvimento. Eles possuem uma visão de mundo peculiar e nos levam a perguntar quem são os chicanos, afinal? O que os autores desejam mostrar com seus discursos centralizados nesse grupo como alvo de suas preocupações?

Anzaldúa e Gómez-Peña partem de um olhar coletivo e exercitam a representação do jogo de tentativa de reconhecimento do grupo. O caráter dessas questões nos faz perguntar ainda: como os chicanos podem ser reconhecidos como pertencentes a um "povo", a uma "nação"?

A linguagem utilizada para representar os chicanos na própria noção de sujeito (identidade) implica, para eles, reconhecerem-se como presença da autoridade estabelecida por meio do exercício em dizer "quem somos". Gómez-Peña e Anzaldúa se veem legitimados como a representação híbrida estabelecida, reflexo da duplicidade entre os objetos do mundo 
ao seu redor e o colonialismo a que foram submetidos. Eles produzem questionamentos para criar um efeito que demande uma adaptação entre o antigo e o novo discurso, revelando a presença de opiniões contrastantes.

Podemos considerar esses "sujeitos" como um tipo de cisão que, do ponto de vista do colonizado, gostariam de alcançar a posição de superioridade ocupada pelo colonizador, embora não se desliguem de sua antiga condição. Vale ressaltar que esta equivalência os coloca em uma divisão como eu/outro, sujeito/objeto. Com isso, a imagem construída de uma "identidade" é aquela a partir da qual o sujeito enfrentará tentativas de transformação - o sujeito se apropria e ao mesmo tempo se integra com o Outro, forma um hibridismo que não é estanque, mas que, ao mesmo tempo, não deixa de camuflar a percepção da diferença.

Nesse espaço, portanto, nasce a "identidade" chicana, com suas tradições e invenções que, quando em contato com outras identidades, cria novas produções, subvertendo valores.

A postura (autobiográfica) adotada por Anzaldúa e Gómez-Peña representa os novos espaços surgidos na (re)construção identitária de sua nova cultura "transfronteiriça" emergente, ou seja, os chamados espaços chicanos nos Estados Unidos. As obras dos referidos autores sugerem que, para além da curiosidade contextual e da arte de sobrevivência cotidiana, eles precisam apresentar e tirar das sombras a experiência vivida pela comunidade chicana. O herdeiro mais ilustre da materialidade "quem somos/quem são" abrange, por isso mesmo, uma rede de características que se sobrepõe e que, de alguma forma, permanece como a "essência" chicana constante. Anzaldúa e Gómez-Peña não se negam, como também precisam conviver com a contradição da heterogeneidade.

O exercício de reconhecimento, então, passa a ser o projeto de os chicanos se constituírem como um povo, uma nação, colocando-os, todos, em inter-relação com ideias, pensamentos e teses para penetrarem nos limites de consciências particulares.

Para Bhabha, é notável nessa possibilidade enunciativa que 
O conceito de povo não se refere simplesmente a eventos históricos ou a componentes de uma corpo político patriótico. Ele é também uma complexa estratégia retórica de referência social: sua alegação de ser representativo provoca uma crise dentro do processo de significação e interpelação discursiva [...] o povo consiste também em "sujeitos" de um processo de significação que deve obliterar qualquer presença anterior ou originária do povo-nação para demonstrar os princípios prodigiosos, vivos, do povo como contemporaneidade, como aquele signo do presente através do qual a vida nacional é redimida como um processo reprodutivo [...] É através deste processo de cisão que a ambivalência conceitual da sociedade moderna se torna o lugar de escrever a nação. (1998, p. 206-207)

É interessante, nesse caso, podermos perceber, por meio dessa significação, que o processo pelo qual as construções socioculturais chicanas se formam podem se modificar em sujeitos de sua própria história e de sua experiência. O choque entre "mundo" e "local" extrai identidades plurais, ou seja, a alteridade de sua racionalidade política provém dos limites heterogêneos e diferenciadores do território que ocupam na atualidade. Ainda de acordo com Bhabha,

o povo não mais estará contido naquele discurso da teleologia do progresso, do anonimato de indivíduos, da horizontalidade espacial da comunidade, do tempo homogêneo das narrativas sociais, da visibilidade historicista da modernidade, em que "o presente de cada nível [do social] coincide com o presente de todos os outros, de forma que o presente é uma parte essencial que torna a essência visível" A finitude da nação enfatiza a impossibilidade de tal totalidade expressiva com sua aliança entre um pressente pleno e a visibilidade eterna de um passado. (1998, p. 213-214)

A partir dessa ampla conscientização, como não considerarmos a revelação das complexidades históricas locais dos chicanos, processos interagindo com a perspectiva emergente de poder considerá-los, realmente, uma nação?

Desde o Movimento Chicano criado em meados do século passado, é possível visualizarmos o espaço no qual os chicanos elaboraram uma nova lógica, o reflexo de um "sujeito superior" ao colonialismo e que, na atualidade, parece identificá-los consigo mesmos e com o espaço-nação estabelecido pelas “diferenças”.

O modelo no qual Anzaldúa se baseia para afirmar que os chicanos são uma "nação" é que ela não ignora as maneiras discrepantes e contraditórias a partir das quais os sujeitos podem ser abordados. O fato de os amigos e a comunidade se juntarem a ela para 
apresentarem um indício irrefutável de que são, na "realidade", um povo, nos leva à seguinte passagem em sua obra:

\begin{abstract}
Para um povo que não é espanhol nem vive em um país em que o espanhol é a primeira língua; para um povo que vive em um país em que o inglês é a língua reinante mas não é inglês; para um povo que não pode se identificar inteiramente com o espanhol (castelhano) e tampouco com o inglês, que recurso the resta senão criar sua própria língua? Uma língua à qual eles podem conectar sua identidade é aquela capaz de comunicar as realidade e os valores verdadeiros para eles próprios - uma língua cujos termos não são nem espanhol nem inglês, mas ambos. Nós falamos uma mistura, uma língua bifurcada, uma variação de duas línguas.

O espanhol chicano desenvolveu-se entre as necessidades dos chicanos para identificarmo-nos como um povo distinto. Precisávamos de uma língua com a qual pudéssemos nos comunicar, uma língua secreta. $(1999, \text { p. } 77)^{4}$
\end{abstract}

Daí o existir das leis na criação dessa nova "nação": eles precisam de uma língua que os identifique como chicano/a. A língua enfatiza a pulsão dada à tradução cultural, aos lugares híbridos de sentido, à dúvida e à inovação.

A questão está em refletir sobre o processo de transformação de antigos requisitos para saírem da condição de subalternos, para reescreverem sua própria história. Senão vejamos a declaração dada por Arteaga, abordando a relação entre língua, subjetividade e nação:

\begin{abstract}
Essas questões de subjetificação afetam-se pessoalmente na forma pela qual concebo a mim mesmo em relação à nação e ao ethnos. Nasci na Califórnia e sou cidadão dos Estados Unidos, mas minha relação com esta nação é problemática. Os nacionalistas anglo-americanos dos Estados Unidos definem sua nação excluindo meu povo. Hoje na Califórnia, por exemplo, o governador republicano e as duas senadoras democratas aliam-se ao gerar uma histeria anti-imigrante (isto é, de mexicanos nos Estados Unidos): que a xenofobia norte-americana me estrangeiriza é um fato de meu cotidiano. Minha nação não é o México, contudo sou etnicamente mexicano e racialmente mestiço. Mas meu povo existe nas bordas que atravessam as fronteiras nacionais dos Estados Unidos e do México. É obvio para nós que a língua que falamos tanto reflete quanto determina nossa posição em relação às duas nações [...] Ser mexicano na Califórnia ao fim do século 20 significa ser constantemente um Outro oprimido dentro dos discursos de raça, etnia e nação numa sociedade racista, etnocêntrica e nacionalista. (2003, p. 319)
\end{abstract}

Focalizando nossa atenção nesse desenvolvimento, podemos dizer que os chicanos se autoconstituíram como cidadãos por levarem consigo o (re)nascimento de um novo presente. Há muito tempo seus ancestrais têm orientado sua luta na formação dessa nova "figura", a diversidade linguística cultural chicana. A ação interativa de circulação fez a língua os 
aproximar das mensagens enunciadas. As histórias em torno do presente linguístico argumentam sobre a história comum que os afeta como uma "Raza" emergente.

Por meio de uma linguagem nova e suas figurativizações, o chicano e sua cultura emergem. As ações massivas da população demonstram participações em escolas e na mídia, em exposições e na capacidade de criar hábitos culturais duradouros.

A partir de então, diferentes materiais vêm sendo incorporados não apenas à cultura chicana, mas, também, à ilimitada rede mundial. E se Gómez-Peña e Anzaldúa deram-se conta dessa ferramenta que, inclusive de maneira virtual, afeta a todos, devemos nos deter um pouco nessa visão sobre a importância desses autores no agora "mundo globalizado" em que vivemos.

Os artistas percebem a impossibilidade de segregar arte e ciência e, com isso, defendem a impossibilidade de se compreender o futuro das artes em geral caso não se dê atenção à ciência e à tecnologia. Os espaços artísticos estão sendo produzidos para que a sociedade os consuma como circulação estético-visual. E mais: a mídia tem feito essa circulação ser bastante fluida e mais complexa, atingindo níveis, gêneros e formas de culturas cruzando identidades.

O fenômeno é emergente e toda essa transformação nervosa faz os fragmentos descentrados da sociedade se "politizarem" em ações e dilemas políticos urgentes. Segundo Mignolo,

O processo de globalização em curso não é um fenômeno novo, embora a forma pela qual está ocorrendo não tenha precedentes. Em escala maior, a globalização do fïm do século 20 (que ocorre sobretudo através de corporações transnacionais, da mídia e da tecnologia) é a configuração mais recente de um processo que remonta aos anos 1500, com o início da exploração transatlântica e a consolidação da hegemonia ocidental. Paradoxalmente, o início dos períodos moderno e colonial (aproximadamente 1500-1700, com a supremacia dos impérios espanhol e português), bem como os períodos moderno e colonial (aproximadamente 1700-1945, com a supremacia do império britânico e o colonialismo francês e alemão), foram aqueles em que ocorreu a consolidação das línguas nacionais, concomitantemente com as migrações fomentadas pela exploração transatlântica e por melhores meios de transporte. Esse progresso criou as condições necessárias para solapar a pureza de uma língua unindo uma nação. A construção do primeiro navio a vapor gigante (entre 1852 e 1847) possibilitou migrações transatlânticas até então impensáveis. Milhões de pessoas migraram da Europa para as Américas entre 1860 e 1914, complicando o mapa lingüístico colonial e fazendo exigências crescentes às geografias 
literárias nacionais [...]. As migrações de indivíduos e a internacionalização de capitais durante a segunda metade do século 19 influenciaram a difusão da cultura impressa e da educação geral, enfatizada pelos construtores das nações nas duas Américas. Assim, em fins do século 19, os legados ameríndios tornavam-se relíquias de museu, mais uma realidade do passado do que uma força crítica do presente. $\mathrm{O}$ nahuatl, entre outras, foi eliminado por lingua(jamento) nacional e tornou-se uma língua (isto é, um objeto) do passado, em vez de uma atividade de linguajamento de milhões de pessoas. (2003, p. 322)

A ideia de globalização refere-se, dessa maneira, às condições de perdas de determinadas experiências e à aquisição de novas experimentações, uma vez que ela se desencadeia durante os processos crescentes de transformações fora e dentro das culturas espalhadas pelo mundo afora. Entre os extremos são verificadas contribuições e novas transgressões que, se solidificadas, comprovam os impressionantes avanços técnicocientíficos e culturais que enfrentamos como desafios pós-modernos. As relações corpotecnologias têm acompanhado e dotado de imaginação criadora uma porção de novas descobertas que acabaram equipando os sujeitos para as suas produções artísticas. Os novos elementos formam poéticas de trabalhos realizados em múltiplos ambientes.

O "lugar" do qual um sujeito globalizado deve surgir parece estar na seguinte declaração de Gómez-Peña:

\begin{abstract}
Os paradoxos se multiplicam locaritmicamente. $\mathrm{Na}$ era dos computadores, dos faxes, da realidade virtual, do World Beat, e da "televisão total" (à la CNN), tem-se tornado incrivelmente difícil para nós nos comunicarmos por meio das fronteiras da cultura e da linguagem. Quanto menor e mais concentrado o mundo se torna, mais estranho e incompreensível ele nos parece. Agora, nós estamos expostos a muitas línguas, mas nos faltam as chaves para a tradução. Temos acesso a incríveis somas ou informações, mas não temos os códigos para decifrá-las. O sedutor universo virtual, com suas ilimitadas opções assim como suas promessas multidirecionais, confunde nossa habilidade de ordenar informações, e agir no mundo com ética e clareza política. $\left(1996\right.$, p. 171) ${ }^{5}$
\end{abstract}

O movimento das experimentações nas suas interações dialógicas navega por meio de inúmeras arquiteturas informacionais provenientes de estruturas (hiper)midiáticas. E desse "mundo" global parece que a "terra" torna-se um tipo de metáfora para locais particularizados de espaço, traçando conteúdos exteriores a uma única "verdade". A ideia envolve todo o "planeta" e cada usuário domina interações em tempo real entre corpos físicos e virtuais. Os 
estímulos acontecem em várias direções, dedos se entrelaçam para traçar outras "linhas" e, então, Anzaldúa pode ser trazida, neste momento, com esta afirmação:

E me sento aqui, frente a meu computador, Amiguita, meu altar no cume do monitor com a vela da Virgen de Coatlalopeub e o incenso queimando. Minha companhia, uma serpente de madeira em bastão com plumas, está à minha direita enquanto pondero as maneiras pelas quais a metáfora e o símbolo concretizam o espírito e eterealizam o corpo. $(1999, \text { p. } 97)^{6}$

Como podemos perceber, as poderosas tecnologias atuais globalizam e revolucionam as informações de maneira sem precedentes. A chamada revolução digital está presente nas reflexões étnico-artísticas e mistura formas, gêneros, atividades, estratos, dinâmica comunicacional em um processo de presentificar o mundo em sintonia com as dinâmicas virtuais. A violenta descoberta é inquietante.

O crescente mecanismo dessas liberdades acelera o que antes era uma simples informação burocrática, para se transformar no estado mais moderno de organizações infinitamente navegáveis. Os mecanismos para isso afloram de todos os lados e permeiam a mistura. As relações estão em jogo e desse regime de signos se perspectivizam outras linguagens e suas propriedades internas, outras enunciações. A seguinte passagem em Santaella, auxilia-nos a entender essa perspectiva tecnológica:

\begin{abstract}
A descontinuidade das mídias não muda apenas nossa forma de pensar. Essa descontinuidade é perfeitamente homóloga aos modos contemporâneos de viver. Basta imaginar como se processa o cotidiano de uma pessoa em uma grande cidade, acompanhada de um celular conectado na internet, de um notepad, ou mesmo de um notebook, movendo-se no trânsito caótico, atendendo a compromissos.

Enfim, a não linearidade das mídias já está encarnada na própria maneira de viver. É certo, porém, que essa descontinuidade é levada a extremos nas mídias que nos dão a capacidade de acessar qualquer ponto randômico e, então, facilmente saltar para outro, sejam esses pontos páginas de um processador de texto, informação em um disco ou outro recurso de arquivamento, ou mundos digitais localizados em qualquer lugar do universo ligado na internet e naquilo que passou a ser mais genericamente designado como ciberespaço. (2003, p. 97)
\end{abstract}

Por isso, de qualquer forma, essa análise tratará do nascimento da nação chicana baseada nas seguintes oposições: a prevalência do mítico e a reviravolta interessante dada na busca desse povo para dentro das artes midiáticas. Sem deixar de pensar que essa mesma 
identidade está posicionada no tripé Aztlán, barrios, fronteira, as contribuições para empreendermos essas "viagens" encontram-se disponíveis no ambiente organizado internamente para nossa leitura. A palavra, agora, demonstra a originalidade que se pode encontrar nas obras em estudo.

\section{NOTAS}

1- O termo "mestiçagem", segundo Carrizo (2005), pode ser considerado, para o nosso propósito, como o "lugar" em que as migrações se mesclam e se misturam, resultando em traços de culturas e identidades diferenciadas. Mestiçagem caracteriza os diversos saberes que associam-se às diferentes identidades, às diferenças que geram novas experiências, e aos fragmentos que apoiam-se em outros processos de conhecimento. Canclini (1997) prefere o termo "hibridismo", pois este associa-se à mistura de diferentes raças, de diferentes credos, abarcando as variadas mesclas inter e intraculturais. Assim, ambos os termos indicam que lidamos com misturas não no sentido de fundir as coisas, mas no sentido de colocá-las lado a lado, a fim de transcendermos os opostos, de abarcar e compreender, de incluir e não de excluir as diferenças.

2- "Fundado em 1965 por Luis Valdez, o El Teatro Campesino era inicialmente uma ala do United Farm Workers Union (sindicato) no vale central da Califórnia. Com uma missão política demonstrativa, o ETC encenou seus "actos" nos campos. Suas improvisações comunicavam eloquentemente junto aos trabalhadores, que não sabiam ler nem escrever, mas reconheciam a si e seus valores nos atos. Por volta do ano de 1970, o ETC ganhou projeção internacional com grandes contribuições à cultura chicana nos Estados Unidos e à expansão de suas fronteiras teatrais por toda parte. O teatro deles é um teatro popular com raízes nas ruas norte-americanas, no início da História da Califórnia, na mitologia Maia/Asteca e folclore mexicano, todos direcionados para a expressão das percepções social, política e cultural".(disponível

em $<$ https://hemi.nyu.edu/artistprofiles/index.php?lang=Por\&artist=etcampesino\&Menu=S $>$ ). Acesso em: 18.fev.2008.

3- "La Pocha Nostra é uma organização de artes transdisciplinares em constante transformação, fundada em 1993 por Guillermo Gómez-Peña, Roberto Sifuentes e Nola Mariano, na Califórnia. O objetivo era conceitualizar formalmente as colaborações de Gómez-Peña com outros artistas performáticos. Fornece uma base (e fórum) para uma rede solta de artistas rebeldes de várias disciplinas, gerações e antecedentes étnicos cujo denominador comum é o desejo de atravessar e apagar as fronteiras perigosas entre a arte e a política, a prática e a teoria, o artista e o espectador. A partir de junho de 2006, incluemse como integrantes, os artistas performáticos Guillermo Gómez-Peña, Violeta Luna, Michelle Caballos e Roberto Sifuentes; os curadores Gabriela Salgado e Orlando Britto; e mais de trinta associados em todo o mundo em países como o México, a Espanha, o Reino Unido e a Austrália. Os projetos variam entre performance solo e duetos até instalações performáticas em larga escala incluindo vídeo, fotografia, áudio e ciber-art. La Pocha colabora através de fronteiras nacionais, raça, gênero e gerações. Seu modelo de colaboração funciona como um ato de diplomacia cidadã e como um meio de criar "comunidades" de rebeldes com a mesma mentalidade. A premissa básica destas colaborações está fundada sobre um ideal: se aprendermos a atravessar fronteiras no palco, poderemos aprender a fazê-lo em esferas sociais muito maiores. La Pocha luta para erradicar mitos de pureza e dissolver fronteiras que circundam a cultura, a etnicidade, o gênero, a língua e o métier”. (disponível em:<http://hemisphericinstitute.org/artistprofiles/index.php?lang=Por\&Artist=lpnostra\&Me >). Acesso em: 18.fev.2008.

4- "For a people who are neither Spanish nor live in a country in which Spanish is the first language ; for a people who live in a country in which English is the reigning tongue but who are not Anglo; for a people who cannot entirely identify with either standard (formal, Castillian) Spanish nor standard 
English, what recourse is left to them but to create their own language? A language which they can connect their identity to, one capable of communicating the realities and values true to themselves - a language with terms terms that are neither español ni inglés, but both. We speak a patois, a forked tongue, a variation of two languages. Chicano Spanish sprang out of the Chicano's need to identify ourselves as a people. We needed a language with which we could communicate with ourselves, a secret language”. (ANZALDÚA, 1999, P. 77)

5- "The paradoxes multiply locarhythmically. In the era of computers, faxes, virtual reality, World Beat, and "total television" (à la CNN), it has become increasingly difficult for us to communicate across the borders of culture and language. The smaller and more concentrated the world becomes, the more foreign and incomprehensible it seems to us. We are now exposed to many languages, but we lack the keys to translation. We have access to incredible amounts or information, but we don't have the codes to decipher it. The seductive virtual universe, with its unlimited options and multidirectional promises, confounds our ability to order information and to act in the world with ethical and political clarity." (GÓMEZ-PEÑA, 1996, p. 171)

6- "I sit here before my computer, Amiguita, my altar on top of the monitor with the Virgen de Coatlalopeub candle and copal incense burning. My companion, a wooden serpent staff with feathers, is to my right while I ponder the ways metaphor and symbol concretize the spirit and etherealize the body". (ANZALDÚA, 1999, p. 97) 


\subsection{Produzindo um meio de se enunciar: a esfera narrativa}

Determinadas atividades narrativas sempre circularam entre os autores chicanos Guillermo Gómez-Peña e Gloria Anzaldúa, uma vez que suas "realidades” ocupam momentos de observações, de surgimento de novas identidades, de separação ou até mesmo de envolvimento com outras culturas. Tamanho espaço referencial não pode cair no apagamento da memória, uma vez que suas histórias contribuem para divulgar os "mitos" considerados os formadores de suas identidades. Em consequência, surge a oportunidade de se registrarem os modos de eles situarem os confrontos traduzidos em eventos atemporais, dando origem aos "sentidos" de uma luta política que os faz exteriorizar novos espaços e espacialidades sociais.

A noção de acontecimento produzida por seus textos forma uma espécie de entrecruzamento enunciativo que perspectiviza diferentes "significados", posto que estes não são gratuitos e tampouco identificáveis como apenas outro significado efetivando o imaginário. Em meio a uma infinidade significante, os acontecimentos narrados em suas obras ganham uma opacidade de sentidos (a ambiguidade significante), pronta para ser reconhecida como a falta deixada pela distância do invisível da origem. O conjunto de signos relacionados com a ideia dá início, dessa forma, a novos modos de expressão e é possível percebermos as diferenças nacionais, culturais e raciais existentes entre o país de origem, o México, e a cultura do país para o qual imigraram, os Estados Unidos da América.

Com o passar do tempo, o espaço constituindo relações entre suas atividades empíricas e as respectivas representações, formou um tipo de consciência a ser interpretada como uma atividade humana que necessitava se manifestar não apenas como prática individual necessária para formação de um determinado discurso, mas como prática de linguagens conclamando o Outro para perceber diversos sentidos que possibilitassem outras leituras. Para os mexicanos que foram para os Estados Unidos, como é o caso de Gómez-Peña e Anzaldúa, 
parece claro que o exílio interno sentido por eles e o deslocamento no tempo e no espaço acabam fazendo parte de sua natureza.

Os aspectos primordiais de um mundo a ser experimentado começam a tecer suas tramas e passam a envolver os autores e os leitores por meio da construção de um conhecimento apenas encontrado no território da linguagem, revelando a percepção daquilo que era considerado real para aquela experiência. Percebendo que têm a possibilidade de selecionar e reunir fatos e escrever sobre suas práticas, Anzaldúa e Gómez-Peña constroem um determinado sistema de valores a partir do qual vão edificando as bases de seus processos de reescritura da realidade.

Construindo suas histórias por meio de um possível imaginário sócio/individual, eles manifestam um mecanismo de produção, uma memória coletiva atestando a realidade vivida, ao mesmo tempo em que reelaboram as referências que recebem do grupo, ou seja, dos chicanos. Anzaldúa e Gómez-Peña conseguem transformar a realidade apreendida, e dão início ao processo de contar histórias, um posicionamento substituindo a extensão deixada por aquele espaço carregado de percepções. Afinal, narrar fatos que vão desde a derrota na guerra México/Estados Unidos de 1848, além das deportações, da repressão social, culminando com o enfrentamento da violência, temor e preconceito exercido sobre eles por parte da sociedade norte-americana, não é tarefa muito fácil.

De uma forma ou de outra, Anzaldúa e Gómez-Peña organizam seus registros narrando sobre esse ou aquele fato sócio-cultural, essa ou aquela situação histórica, essa ou aquela outra personagem. Os acontecimentos são diferentes de um dia para o outro, e o resultado dessas mudanças é registrado como forma de se conceber uma transmissão temática. Eles narram que os mexicanos e seus descendentes nos Estados Unidos não são passivos e tampouco permanecem prostrados. Embora não tenham recuperado o território geográfico perdido para os Estados Unidos, os chicanos conseguiram criar uma tradição de resistência 
cultural que se opõe a uma dominação social e econômica imposta pela colonização da cultura anglo-americana. O cotidiano do grupo passa a ser inserido, dessa forma, em um universo de discursos e o resultado das muitas vozes, dessa polifonia, reflete e manifesta as reproduções (re)elaboradas pela carga do universo ao qual pertencem.

Perspectivizando a lógica da sequência narrativa, os autores conseguem ressignificar um dia de luta em defesa dos mexicanos. O objeto de conhecimento se transforma de "um algo em si” para um "algo para o grupo". Anzaldúa e Gómez-Peña fundamentam suas percepções do mundo e as articulam para fins de produção de sentidos. Suas verdades (parciais ou não) têm se estabelecido por meio de organizações que dispensam a mera decodificação. Eles acumulam saberes e, com estes, a memória que lhes permite um efeito de ordem significante.

Nesse sentido, a crescente preocupação em registrar o que lhes acontece no cotidiano serviu para que fossem montando os processos pelos quais passavam na formação das diferentes linguagens. Todas essas inquietações resultaram, mais tarde, em maneiras de se expressar, em produção cultural, armazenando informações. Os autores organizaram toda uma construção de presenças entre presente e passado, presente e futuro, produzindo, assim, seu "universo narrativo". Dessa forma, podemos reconhecer em suas narrativas, o que lhes sucede na materialidade do dia-a-dia e apreendermos suas inquietações.

Na verdade, objetivamos demonstrar que, ao apresentarem seus registros, Anzaldúa e Gómez-Peña nos legam uma forma de contar sobre a vida, de focalizar acontecimentos confrontando complexas questões a respeito da vida e da arte em geral. A arte produzida por eles desafia as formas de interpretação conhecidas. Segundo Baccega,

Para a construção da realidade e o conhecimento dela, o homem, entre outras coisas, apropria-se dos sentidos das palavras, dos signos, reelaborando-os. A práxis inclui, portanto, o conjunto dos campos semiológicos, das atividades já produzidas e o conjunto dos comportamentos que queremos atingir. São campos semiológicos os vários campos pelos quais transitamos cotidianamente, formados com as diferentes linguagens (gestos, arquitetura, música, dança, pintura, escultura, etc). (2003, p. 36) 
Anzaldúa e Gómez-Peña mostram-se, portanto, interessados em atualizar suas vivências e manifestam algumas atuações que, na contemporaneidade, representam formas de escritura em diferentes formas de discursivizações.

Eles mantêm uma maneira de impactar seus leitores com as histórias narradas; dirigem-se ao próprio ser da linguagem; narram meticulosamente suas experiências, seus encontros, seus signos improváveis. Eles têm o dom de pronunciar o vazio a ser substancializado por suas palavras, gerando tópicos que até pouco tempo eram ignorados. Mais do que uma simples materialidade, os narradores dão origem à existência do que sempre esteve ausente, criam um corpo figurativizando tantas linguagens quantas forem suas necessidades de expressão.

Estas questões são multifacetadas e para reconstruir o mundo narrado é preciso justapor a ele imagens que, na realidade, nunca aparecem juntas. O narrador de suas histórias sempre recria o fato por meio de imagens e objetos deixando transparecer que ele jamais se conforma com a realidade.

Em meio a este estado nômade de caracterizações, as narrativas de ambos os autores passam a articular profundas polêmicas e ambiguidades, tentando redefinir as representações do passado e do presente, a fim de torná-los familiar.

Narrar, para eles, tem se transformado em uma espécie de movimento no qual se decompõem e se confrontam tantas histórias ao mesmo tempo. Elaborar fatos para serem narrados tornou-se o mesmo que reconstruir o passado em uma prática do presente. Para construir suas narrativas, Anzaldúa e Gómez-Peña utilizam-se de várias espécies de textos, de diferentes campos semiológicos em cujo processo esse mesmo sujeito está inserido.

Narrar transporta para os autores, agora, o indicativo de "passagem", um fenômeno conveniente para relacionar determinada produção artística, crítica e também político/literária, com conteúdo sócio/cultural e suas evoluções. Narrar passa a ser o local de interpretação do 
fato em si e de seus aspectos; a constatação das catástrofes, das guerras, terremotos, epidemias, sacrifícios humanos, tudo midiatizado por objetos ou signos, levando a uma mistura que dá a impressão de real do fato narrado.

Assim sendo, eles já não se satisfazem por experimentar uma única forma de representar a realidade, mas buscam redefinir a significação de suas identidades. O resultado é uma visão privilegiada sobre misturas raciais e étnicas contidas em suas enunciações.

Sem procurar estabelecer as mesmas práticas de representação, suas narrativas trazem em si retalhos secretos de paixões e mortes, infância e perdas, confissões e culpa, amor e ódio, natureza humana e utopias, numa mescla de culturas. É como se tudo isso se misturasse em uma espécie de paixão pelo risco (de escrever), ou, melhor, Anzaldúa e Gómez-Peña narram representações polimorfas, articulam a diferença, assim como constroem ilimitadas leituras imagéticas sempre enfocando a importância de grandes diálogos com outros discursos. Nessas ramificações desenvolvem-se os gêneros abordados por eles.

Compreender a maneira de narrar desses autores, portanto, implica nos defrontarmos com hábitos intelectuais bastante mudados e diferentes do cânone. É preciso que os fragmentos sejam apreciados para que eles formem um possível todo. Não se pode mais limitar terrenos; não há como ser de outra forma para se observar o que sobra da possibilidade da imagem. Assim, somos levados a espaços dualistas, e não aos monolíticos.

Precisamos rumar por um certo caminho que nos conduza a perceber outros valores e condições de transição para aportarmos em outras margens. Só assim estaremos aptos a entender a confluência de duas ou mais correntes de saberes narrativos, de cruzar fronteiras para percebermos a narratividade em Gómez-Peña e Anzaldúa, autores compromissados em questionar os valores dos Estados Unidos e a estética dominante.

Nessa trajetória, defrontaremo-nos com o que é novo, com o que está emergindo. De acordo com Torres, 


\begin{abstract}
A literatura de subgrupos étnicos frequentemente cruza as fronteiras disciplinares, porque ela imbrica o cultural e o histórico no literário, exigindo uma abordagem que escapa ao confinamento de modos tradicionais de análise. Quando qualificamos determinada literatura como chicana, nuyorican ou cubano-americana, já estamos, na verdade, traçando um percurso de investigação que se situa na interseção entre uma percepção canônica e uma percepção marginal da literatura norte-americana entre a tradição do centro e as demais tradições nele contidas [...] A expressão literária dos grupos hispânicos dentro dos EUA ainda ameaça o cânone, na medida em que introduz elementos culturais e, sobretudo, lingüísticos à literatura norte-americana [...] não se trata de subsumir expressões "estrangeiras" a determinada literatura nacional, mas de reestruturar o cânone, transformando-o em uma expressão poliglota das diversas nações que ocupam um mesmo mapa. (2001, p. 13)
\end{abstract}

Sendo assim, precisaremos nos dedicar à tarefa de recompor relações, ajudados por um material que nos faça perspectivizar métodos transdisciplinares para percebermos que nesses lugares intervalares surgem identidades híbridas falando de culturas multifacetadas, relacionando-se com o outro de uma maneira diversificada. O lugar da narrativa chicana não deve ser entendido como algo transcendental e tampouco pedagógico dado pela História, mas como um movimento que oscila no presente e no passado da cultura.

Para discutirmos esse novo fenômeno, buscamos suporte no discurso teórico de Sonia Torres, Homi K. Bhabha, Walter D. Mignolo, Lucia Santaella, Néstor García Canclini e outros estudiosos para termos a base construtiva que nos permita sair de uma única dimensão para abarcar as identidades discursivas que englobam e ultrapassam dimensões abertas para além de um monolinguajar. Segundo Torres,

\begin{abstract}
A crescente interdependência e interseção dos fluxos locais e globais, nacionais e internacionais (política e economicamente assimétricos, é importante frisar) levam a discursos nacionais cada vez menos baseados na identificação Estado/nação, e cada vez mais baseados na identificação cultura/etnia. (2001, p.13)
\end{abstract}

Assim, a nossa articulação para produzir considerações a respeito dos autores liga-se a debates de ideias tais como transculturação, hibridismo, impuro, entrelugar, novas identidades e fronteiras, a fim de tornar legítima a voz narrativa dos autores em estudo.

Nesse processo, o vocábulo fronteiras se refere às manifestações polifônicas envolvidas nas circunstâncias inesperadas de qualquer mudança. As fronteiras são utilizadas quando se referem a um vasto número de outras vozes e histórias sobre grupos minoritários, 
suas culturas e identidades; quando nos referimos a histórias de migrações pós-coloniais; quando refletimos sobre questões de colonizadores e colonizados; quando fazemos leituras sobre a poética dos exilados e dos refugiados; ou, quando cremos, enfim, no internacionalismo político e econômico de grupos sociais. Para Torres,

\begin{abstract}
autores celebram a fronteira como um espaço móvel, polifônico, híbrido, feito de incessantes travessias, externas e internas. Há, ainda, obras que se dedicam a esmiuçar localidades fronteiriças específicas como zonas de contato cultural onde as duas histórias, a "anglo" e a mexicana, colidem [...] A fronteira Tex-Mex é maior que as dos demais estados, e gerou uma cultura muito particular, tanto literária quanto na área da música, das artes plásticas e da culinária. De um modo geral, o espaço representado nas obras de autores tejanos está fortemente identificado com suas comunidades de nascença, mesmo quando eles não residem nelas. (2001, p. 31-32)
\end{abstract}

Nesse jogo para estabelecer conexões integrando espaços vazios está a perspectiva de deslocar totalidades hegemônicas que eram tidas como discursos insubstituíveis. Pelo ato de narrar, conseguem-se novos modelos expressivos configurando um outro jogo de confrontos entre inclusões e exclusões significativas. Resulta daí o estabelecimento de uma "tensão" que nos leva a perceber uma alternância entre ser e não-ser, requerida pela busca de sentido. De acordo com Bhabha, a fronteira é aquele "lugar a partir do qual algo começa a se fazer presente em um movimento não dissimilar ao da articulação ambulante, ambivalente, do além que venho traçando [...]" (1998, p. 24).

A linguagem adotada por Gómez-Peña e Anzaldúa é aquela que provoca e faz circular influências para a criação de um drama moderno que supera a questão do homem frente à sua identidade. A força de seu discurso na comunicação fica evidenciada quando cumpre uma função social específica na totalidade dessa mesma sociedade.

Os autores criticam um determinado tipo de linguagem que permite o surgimento de vários outros campos significativos tal como se referencializam em determinado momento histórico. 
Encontramos, dessa forma, o suporte para organizar nossas ideias em torno de novas identidades. Reconstruindo o campo argumentativo de buscar soluções, o termo identidade, hoje, é visto como uma categoria discursiva, e não como uma crença acabada que se refere a um conjunto específico de pessoas. Se levarmos em conta esse raciocínio, perceberemos que essa lógica revela e reinscreve profundas mudanças no sujeito centrado em certos domínios de outras épocas. A fragmentação identitária desestabiliza o mundo pós-moderno. Os indivíduos sentem-se desarticulados nesse processo contínuo de "crise de identidade", e ocorrem mudanças e deslocamentos de estruturas fortemente alicerçadas até então.

Não é mais possível pensarmos sobre um caráter específico a respeito de uma identidade. Ora, grupos sociais, etnias, raças, e outras denominações estão em processo de mudança constante, o que resulta em outras perspectivas sobre essas categorias. Stuart Hall fala em "pluralização" de identidades (2003, p. 18). Para ele, é importante mostrar como o "sujeito humano" está sendo "descentrado na modernidade tardia" (2003, p. 23), em uma espécie de pertencimento a várias outras fronteiras, provocando no indivíduo uma verdadeira crise de identidade. A sociedade atual e o sujeito humano, divididos em diferentes gêneros “descentrados", veem-se estranhamente duplicados por essas diferenças, afirma o autor (2003, p. 23-24).

Por meio dessa forma ainda mais difícil de unificar identidades, perceberemos como os autores chicanos em estudo têm as mesmas inquietações. Conforme vão dando a conhecer suas incertezas, visualizamos o esforço que fazem para costurar diferentes divisões e contradições existentes em cada uma das camadas do grupo social a que pertencem. Torres comenta que

\footnotetext{
A política identitária chicana dos anos 60 nasce colada ao Movimento pelos Direitos Civis dos EUA, cuja repercussão na academia foi a criação de departamentos de estudos étnicos, primordialmente dedicados ao estudo da cultura afro-ameriana, em cujo rastro foram criados centros de estudo étnicos voltados especificamente para as culturas hispânicas, como os centros de estudos chicanos ou portoriquenhos. A partir de meados dos anos 70, influenciada pela postura de descentramento dos estudos
} 
femininos e etnográficos, que problematizam a questão da autenticidade como uma narrativa totalizante, a produção artístico-literária chicana começa a voltar-se para a experimentação individual e para a representação da diversidade dentro da cultura chicana. (2001, p. 23-24)

Dessa forma, o momento estranho e angustiante diante do qual Anzaldúa e GómezPeña se encontram é abordado e narrado por eles de várias formas, em uma tentativa de reconstrução do que se fragmentou. Os autores narram suas necessidades espirituais e intelectuais; representam costumes tradicionais e se aprofundam nos questionamentos oferecidos pela sociedade pós-moderna, sugerem histórias deslocadas social e culturalmente, e transmitem todas as angústias diante do mundo. Como renovadores de histórias, registram a conscientização de qualquer indivíduo chicano diante do momento histórico pelo qual está passando. Mais do que se exceder no processo de apreensão do global, os escritores alinhavam seus textos costurando as minúcias dadas pela própria estratégia contextual.

Tudo indica, pois, que o recurso técnico da performance empregado por Gómez-Peña e a maneira de narrar empregada por Anzaldúa levam-nos a comentar sobre um outro conceito. Marcado por uma infinidade de inter-relações textuais, o entrelugar circula na contemporaneidade ultrapassando fronteiras a fim de realinhar, valorizar e resgatar certos costumes nas lutas por territórios e autonomias. De acordo com Santiago (2000), o "entrelugar" é o interstício, ou a fenda que "ampara" uma confluência de valores; é o caminho para as negociações, para o trabalho de produção literária, ou seja, e entrelugar é a identificação entre passado e presente, interior e exterior, inclusão e exclusão, colonizados e colonizadores, europeus e latino-americanos, fazendo todos possuírem seu lugar na cultura e na literatura.

Com o entrelugar surgem as oportunidades de se explicarem o destruído, os novos discursos e os diferentes sujeitos que vão construindo sua história identitária. No entrelugar , o elemento europeu e o sujeito autóctone associam-se em um pensamento progressista dando a conhecer uma nova unidade, mestiça, de releitura dos espaços de enunciação. Ele não nos remete a uma única referência europeia, mas é capaz, sim, de afirmar-se sem excluir o outro, 
de possibilitar-nos viver no meio, no lugar de união, de experimentarmos viver no lugar entre dois mundos.

Ao produzir novos dizeres nesse vasto universo de representações advindas dos sentimentos e das sensações, o entrelugar implica defrontarmo-nos com novos hábitos abraçando heterogeneidades e imprevisíveis universos misturados por uma realidade cotidiana. Nesse sentido, o que se estabelece como a verdade do outro, é transferido deste para aquele grupo que, habitualmente incompatível, cruza fronteiras para dar lugar a um elemento completamente novo (SANTIAGO, 2000).

De forma aparente, o processo utiliza marcas inscritas em alguma observação alhures para, depois, incluir posições antagônicas dentro de um mesmo discurso com o objetivo de estabelecer um diálogo entre realidades diversas. As condições metodológicas contribuem para redefinir os discursos literários e, assim, percebemos os mesmos ideais de Anzaldúa sendo delineados na escritura de Gómez-Peña e vice-versa. Ambos abordam a realidade chicana e, com isso, promovem a reflexão sobre novas perspectivas a respeito desse grupo.

Os autores associam movimentos que acabam desaguando no mesmo lugar de interrelações discursivas e subvertem a noção do reprimido para além da forma do indizível e, com essa decomposição, justificam suas tomadas de posições criando formas de credibilidade. Eles sensibilizam populações e libertam, das instituições acadêmicas, todo um efetivo discursivo para desestruturar o canônico. Dessa maneira, inscrevem-se no novo sentido estético cuja ordem simbólica está além de qualquer identificação específica.

Assim, justapondo o discurso de um e de outro, nosso estudo amplia o campo de visão e enfoca o encontro de fenômenos acontecendo nas experiências culturais tanto quanto entre o indivíduo e o meio ambiente em que trabalham sua arte literária. 
Essas origens "intervalares", como menciona Bhabha (1998, p. 35), produzem um outro tipo de organização de dados na estética narrativa. Essa transformação do real nos é dada pelas obras aqui estudadas.

Analisando manifestações artísticas que se expandiram de maneira intensificada no mundo urbano, vemos as justaposições de significados possibilitarem interpretações fora da ordem habitual das coisas.

O que hoje se nomeia hibridação, elemento híbrido, ou simplesmente híbrido, perpassa antigas associações e nos faz identificar um sentido desagregado de antigas ordens canônicas para resultar na observação de múltiplas temporalidades deslocadas por inúmeros artistas/criadores. Divisões modernas na maneira de escrever interagem com o tradicional, e binarismos espaciais agrupam essas inovações a esferas de uma nova experiência da estética artístico/literária. Moderno e antigo, híbridos mais fortes que cruzam interesses históricos, estéticos e comunicativos. Objetos de museus, hoje, dividem, segundo Canclini, o mesmo espaço de interesse e rememorização com os "monumentos abertos", todos ordenando, de forma simbólica, nossa visita e sua observação. Se os primeiros parecem congelados, os segundos se oferecem "à dinâmica urbana facilitando que a memória interaja com a mudança, que os heróis nacionais se revitalizem graças à propaganda ou ao trânsito" (CANCLINI, 1997, p. 301).

Por essa estranha presença, existe hoje a possibilidade de se combinar a leitura das "grandes obras" com as modas das coleções. O sujeito (leitor) já não se assombra diante de um presente histórico ou diante de um repertório de informações fragmentárias do passado; ele pode passar de um site a outro na internet e ir coligando seus itens de interesse. A população atual é composta por pensamentos que levam de uma sustentação paradigmática para aquela inter-relação com "vizinhos" imediatos. 
São frequentes as ações e os trabalhos de "cruzar fronteiras". O passado é redimensionado e o caráter cultural de um povo passa a se expressar por meio de uma pluralidade de coexistências. Segundo Canclini,

\begin{abstract}
A esses produtos híbridos, simulados, os artistas e escritores da fronteira acrescentam seu próprio laboratório intercultural. Em uma entrevista de rádio, foi perguntado a Guillermo Gómez-Peña, editor da revista bilíngue La Línea Quebrada / The Broken Line, com sede em Tijuana e San Diego:
\end{abstract}

Repórter: Se ama tanto o nosso país, como o senhor diz, por que vive na Califórnia?

Gómez-Peña: Estou me desmexicanizando para mexicompreender-me [...]

Repórter: O que o senhor se considera então?

Gómez-Peña: Pós-mexica, pré-chicano, panlatino, transterrado, arteamericano [...] depende do dia da semana e do projeto em questão. (1997, p. 322 a 324).

Podemos concluir, portanto, que essa mescla, essa migração de saberes habitando o mundo atual são os caminhos percorridos pelos agentes da arte quando se dizem reconstrutores e transformadores de antigas realidades.

Por meio de estratégias tornando possível a circulação de diferentes diálogos discursivos a fim de recuperar estéticas que até então não eram consideradas como argumentação artística, o conceito de impuro é definido como aquele espaço em que estratos narrativos vs. posições políticas adotam certas liberdades não hegemônicas para definir ou analisar um momento histórico/cultural.

A mistura aqui surge não mais como uma distância entre uma performance da significação presente nas enunciações, mas sim, como a outra parte mesclando o convencional e o novo, o tradicional e as mudanças desencadeadas pelas migrações, numa justaposição "impura" que fornece às diversas formas de se expressar, o paradigma migratório para outras linguagens. De acordo com Canclini,

A perspectiva pluralista, que aceita fragmentação e as combinações múltiplas entre tradição, modernidade e pós-modernidade, é indispensável para considerar a conjuntura latino-americana de fim de século. Assim se comprova [...] de como se desenvolveram em nosso continente os quatro traços ou movimentos definidores da modernidade: emancipação, expansão, renovação e democratização. Todos 
se manifestaram na América Latina. O problema não reside em que não nos tenhamos modernizado, mas na maneira contraditória e desigual com que esses componentes vêm-se articulando. (1997, p. 352)

Neste sentido, a alteridade evolui para que possamos debater situações que tematizam a incerteza existente nas fronteiras (sejam elas quais forem) e as estratégias da escrita.

O espaço ressignificativo, então, propicia o trabalho transdisciplinar entre setores populares da vida cotidiana com a ambivalente e antagônica imaginação hegemônica, sendo que a substituição do cenário clássico pelos últimos gêneros discursivos demonstra a militância para se participar social e diretamente de ações mais mercadológicas. Aqueles "bens" oferecidos pela interpelação tradicional se vêem, na atualidade, mesclados a meios eletrônicos e às teatralizações imaginárias do autenticamente popular. A rapidez heterogênea definindo a onipresença dos diferentes gêneros acaba deslumbrando e multiplicando audiências. Grande parte das manobras entre emissor e receptor acabam evocando a população para que o mercado e a mídia se sintam conectados ao substrato da tradição.

O curioso é que essas relações estão, cada vez mais, disseminando-se e ditando a produção a ser consumida, seja como sintoma de mudança, seja como resultado já assimilado. Ainda de acordo com Canclini, a partir dos anos 60,

Escritores, cineastas, cantores, profissionais e estudantes, reunidos nos Centros Populares de Cultura (CPCs) brasileiros, desenvolveram um enorme trabalho de divulgação da cultura, redefinindo-a como “conscientização". No livro que sintetizou o ideário estético-político dos CPCs, Ferreira Gullar escreveu que "a cultura popular é, em suma, a tomada de consciência da realidade brasileira [...] É, antes de mais nada, consciência revolucionária”. (1997, p. 269)

Por tudo isso, o nosso desafio é enfrentar esse "rito de passagem" do que era considerado "puro", "centrado", “uno", para essa ambivalência discursiva do "impuro", “descentrado”, “plural”. Mais uma vez, há que se pensar nas negociações necessárias para que outra estética literária surja dos gestos mais ousados, dos mais contraditórios.

Esses são os componentes fundadores da chamada transculturação, contraponto importante para se vislumbrar as variadas mudanças que marcam a história mexicana. A partir 
do que lhes foi imposto por um "mundo" totalmente estranho quando os espanhóis aportaram em suas praias, a população local sofreu todo um processo de transplantação cultural e espacial.

Muitos anos após essa invasão e a guerra com os Estados Unidos, os chicanos, hoje, expressam uma identidade formando um espaço jovem e quase desconhecido dentro de um outro espaço sustentado por um aparato sócio/cultural ativo, os Estados Unidos. Embora se reconheçam como o espaço do século, poderoso, bélico, ponto de partida para ditar normas econômicas aceitas mundialmente, os Estados Unidos não podem recusar a ajuda da heterogeneidade da população hispânica que vive no país, na qual os chicanos se inserem. $\mathrm{Na}$ atualidade, os hispânicos formam um contingente de mais de 30 milhões de pessoas divididas em várias comunidades tais como os porto-riquenhos, os cubanos, os nuyoricans, e os Estados Unidos reconhecem a importância do voto dessas pessoas, caso queiram se manter como nação que predomina sobre as outras do Ocidente (TORRES, 2001, p. 10).

O que resulta dessa materialidade tem sobre nós um efeito de opacidade cujos "implícitos" tanto podem ser a "mestiçagem" cultural de um povo, suas inúmeras reflexões acerca de suas identidades, quanto as novas linguagens daí surgidas para expressar a identidade de um novo lugar, jovem e desconhecido.

$\mathrm{O}$ aspecto particularmente enfocado quando falamos em transculturação deve ser o de significar um movimento que resulta em diálogos desenvolvendo o encontro entre “identidades" e condições sociais, históricas e econômicas, percebidas nessas possibilidades de confronto. Os perigos das contradições identitárias de uma cultura em relação a outra estão presentes aí, mas, na verdade, a criação e redescobertas sócio/culturais advindas desses encontros possibilitam a incorporação de um outro corpus de novas ideias. 
O contato, na maioria das vezes, estabelece-se de forma violenta e impositora; porém, o resultado é bastante desafiador e interessante, com outras maneiras de retratar novas realidades.

Anzaldúa se dá a conhecer quando narra sobre a tradição e as consequências culturais daí resultantes. Gómez-Peña define-se mais como o acusador contemporâneo das diferenças culturais. Ela narra em prosa e verso; ele, além dessas duas formas, utiliza textos performáticos misturando os três gêneros.

O confronto desses elementos narrativos multiplicando registros evocados por eles surte sobre os leitores um efeito de choque, de um visível não nomeado, um percurso descritivo inscrito discursivamente em outro lugar.

Assim, ambos celebram essas fronteiras como processo de transculturação, o espaço móvel de justaposições conferindo incessantes travessias figuradas e literais. Gómez-Peña evoca a linguagem da música, dos gestos, palavras e movimentos, obrigando-nos a compreender o gesto utilizado nas dimensões da cena no palco. Com isso, ele possibilita que a linguagem literária seja mesclada de gestos e inventa uma nova linguagem, mais abstrata, cujo significado está dentro e fora dela. Mesmo para a sincronia de uma determinada sintaxe, a combinação desta com outra torna-se possível para o momento da escrita. Nada fica incompreensível nesse trajeto referencializando condições de significação, uma vez que o registro do imaginário efetivamente funciona entre sujeitos.

\subsection{A movimentação teórica para discutir os textos de Gómez-Peña e Anzaldúa: a busca pelo não dito}

Objetivando acompanhar a construção estético/literária que Gómez-Peña e Anzaldúa criam para apresentar sua arte de convencimento, reconhecemos nesses escritores a liberdade 
como guia de seus desejos quando querem se expressar pela escrita. De forma indissociável de traços da memória, o desejo busca se efetivar no momento em que reproduz, de maneira alucinatória, aquelas percepções do passado trazidas para o presente por vias de substituições.

Uma vez nascido da perda do objeto que foi proibido pela censura, o desejo se transforma na busca incessante daquela perda que, por sua vez, não para de ser representada por outros objetos. Não se trata de uma infinita repetição tentando mudar o que se produziu até então, mas sim, de um grande labirinto no qual linguagens são experimentadas para expressar o indizível. Nessa experiência, manifesta-se a presença do duplo, o signo advindo de forma simultânea, do Mesmo e do Outro, revelando a linguagem multiplicada ao infinito (FOUCAULT, 2001).

Inseridos nessa condição, não estranhamos quando Gómez-Peña e Anzaldúa escolhem o caminho de se sentirem livres para criarem suas estéticas, porque longe de se apresentarem como seres alienados ou escravizados a um determinado tipo de escritura vigente, nós identificamos nesses sujeitos uma liberdade atentando contra ideologias determinadas por uma pretensa essência hegemônica. Os dois escritores atuam sobre suas capacidades de recriar os fatos vivenciados cotidianamente e fazem uso de suas atividades discursivas para criarem novas realidades. Eles comentam sobre acontecimentos ligados a fatos do dia-a-dia que lhes permitem continuar com o ilimitado da busca, acrescidos por um tipo de questionamento que os faz dar outros sentidos ao espelhado nos fragmentos de suas "falas".

Nesse sentido, ambos mostram a faculdade de não se sujeitarem a qualquer sistema exterior autodeterminado por segmentos mecanizados, mas se movimentam, pelo contrário, por meio de diferentes práticas e privilégios artístico-literários, expressando suas características subjetivas. Eles assumem a posição de que um ser livre é aquele capaz de se orientar e de se autodirecionar, e demonstram ser dotados de autonomia e de faculdade próprias, quando enfrentam a questão da liberdade desejante. Os autores operam de forma 
pluralizada - para eles nada pode ser descartado seja o bom, o ruim ou o feio; nada é rejeitado ou abandonado. Além de sustentarem as contradições, eles transformam a ambivalência em alguma outra coisa completando seus discursos.

Sob o signo da carência, Gómez-Peña e Anzaldúa transitam entre aptidões, sejam elas reflexões ou escolhas, tanto quanto por entre paixões, desejos e propósitos que lhes permitirão serem identificados como sujeitos possuidores de interesses específicos.

Assim, os sujeitos, quando dotados de interesses e desejos, afirmam uma natureza de poder da imaginação, ordenando uma espécie de naturalismo imaginário presente, apenas, naqueles que se envolvem com as utopias da singularidade de criar. O desejo funciona, assim, como símbolo de mediação entre o que falta e o fim em si, resultando diretamente em uma autonomia capaz de se mover daqui para ali em busca de palavras e linguagens e de outras construções exteriorizando aquela singularidade.

Esse contingente conceitual demonstra que ambos os autores viabilizam esse poder porque é próprio da criação artística recriar e redefinir uma ilimitada possibilidade de plurais imaginários. Eles conservam o instinto de se moverem por terrenos cujo valor absoluto não determina um único ordenamento, e apresentam, dessa maneira, a liberdade de realizarem, pelas letras, o desejo de ocuparem um lugar privilegiado dessa liberdade. Isto é, eles carregam um "espaço livre" para testemunharem sobre a infância, ou para narrarem sobre os espaços vazios deixados pelo passado, tanto quanto para manifestarem, por meio de registros, uma ressignificação dos eventos que resistem a especificações envolvidas com a História.

Se é verdade que é impossível separar a História da memória ${ }^{1}$, Anzaldúa e GómezPeña tentam reconstruir o passado por inteiro quando, por meio das lembranças, reconstroem o passado do povo chicano com o auxílio de dados e fatos advindos do presente. Fazendo parte da mistura entre ancestrais indígenas, espanhóis e a vivência na cultura americana, os autores não conseguem afirmar a qual delas pertencem. 
Além de tudo isso, suas posturas, quando visam celebrar um espaço móvel, polifônico, híbrido, querendo se referir a um processo de transculturação, são a de serem vítimas de um confronto com a necessidade de lidar com a nova realidade, a chicana, e a de trabalhar com o passado da etnia, pois, para formarem suas identidades, eles sabem que esse confronto se faz necessário. Além de tudo, os autores sabem que essa identidade nunca é singular, unificada, ou, sequer, autônoma, mas sempre pronta e aberta à multiplicidade.

Usando a escrita, Gómez-Peña e Anzaldúa (re)inscrevem os fatos da tradicional representação no registro da apresentação do agora. Despreocupados com a ideia de limites, quando comentam sobre a história chicana, eles refletem sobre ela e a apresentam como aquele momento crucial comprometido com a ética, a política e a própria História.

Assim, Anzaldúa e Gómez-Peña mostram traços do passado tanto por meio da liberdade de singularizar cada narração sobre fatos ocorridos em suas vidas, quanto pela condição de apresentarem discussões sobre a fragmentação histórica do povo chicano. Escrever ou apontar marcas das atrocidades cometidas pela colonização espanhola é, dessa maneira, se ver livre para narrar sobre conhecimentos passados e para (re)interpretar aquele mundo, transitando no espaço e no tempo de inúmeras formas.

Sem dúvida, a contribuição dada pela escritura dos autores quando apresentam suas obras não é a de uma simples rememoração do passado. Para eles, não importa que esta teoria seja mais apropriada que aquela para se dizer sobre a constituição de identidades chicanas. Eles se utilizam da arte do testemunho ${ }^{2}$ e, por meio dela, reafirmam a força de se trabalhar a memória. Os escritores reinscrevem o passado no presente sob um ponto de vista que, a um só tempo, faz surgir camadas históricas e culturais, reproduzindo variados registros.

Suas narrativas reavaliam a história desde as tradições indígenas até a situação atual dos chicanos. Existe aí uma intersecção comentando múltiplas realidades a respeito de fatos culturais, demográficos, fronteiriços, econômicos. Com esse resgate, Gómez-Peña e Anzaldúa 
mantêm uma relação com o passado das gerações. As histórias explodem fragmentadas e estilhaçadas. É como se o drama da vida fosse concebido em rupturas e retratos de uma imagem tempo/espacial repleta de figuras ambíguas de uma "totalidade" que não existe nem para eles nem para nós.

Assim, ao testemunharem a respeito dos valores chicanos, eles sentem que as respostas dadas pela sociedade são efêmeras, compondo traduções de uma série de vivências aparentando ser uma ressonância invertendo as experiências vivenciadas. Em contrapartida, os autores se mobilizam para impedir o esfacelamento de suas ideias. Pela linguagem artística e pelas letras, eles recriam um espaço imagético de onde é possível surgir, pela palavra, a destreza em se figurativizar o mundo que os chicanos têm construído.

Gómez-Peña e Anzaldúa reavivam a crença de que os artistas são uma espécie de seres do turismo cultural, levando suas experiências para lugares onde se quer ligar esta informação (“eu”) com aquele dado (“isto”). Eles opõem o culto das tradições ao sistema pós-moderno e transcendem os limites entre classes, raças e sexos. "Quem fala" vai ao encontro de algum “outro lugar", esperando encontrar uma resposta que dê sentido para a existência de sua arte. Assim sendo, o que possibilita o sujeito de criar é o fato de se tornar sujeito do próprio desejo, realizar-se ao encontrar sua expressão.

Talvez seja esse desejo que tenha dado início ao chamado chicanismo, ou seja, aos movimentos políticos chicanos iniciados na década de 60, englobando afirmações culturais por meio das quais escritores e artistas plásticos expressavam seu modo de pensar e suas ideologias, tentando ganhar voz. O chicanismo agregava, como tivemos oportunidade de observar, os muralistas e as dramatizações dos campesinos, para demonstrarem sua luta por liberdade de expressão e inclusão social. Por meio de suas diversas atividades, emergiu uma nova consciência política unificando os grupos envolvidos com as causas dos chicanos (TORRES, 2001, p. 22). 
Inúmeros artistas e teóricos compartilhavam do movimento ao marcarem a transformação que os mexicanos, vivendo nos Estados Unidos, tinham sofrido para pensarem sobre si mesmos. Essa transformação possibilitava que eles procurassem mostrar a ramificada tradição de seu passado, assim como as aventuras significativas que se fundiam com o passado de qualquer indivíduo plenamente representado em cada ideia. Combinando conhecimento pessoal, experimentações, projetos, pesquisas, eventos, uma retórica político/cultural, o chicanismo moveu-os como se fosse um ponto de vista multidimensional sui generis no qual se inseria todo o povo chicano.

Observada essa postura, a direção tomada por Gómez-Peña e Anzaldúa nesse tipo de prática inovadora é, portanto, a de dar significado a suas histórias com a possibilidade de uma dialética entre as suas narrativas. "Quem fala" em seus textos é a própria linguagem com suas múltiplas faces, múltiplas liberdades, múltiplos discursos vindos de lugares diferentes dos canônicos.

Anzaldúa apresenta, por exemplo, um momento no qual a liberdade de ação pode ser encarada como a principal forma de adoção, pelos chicanos, de oito linguagens diferentes. E, ainda, marcando sua importância, determinar seu desenvolvimento com uma extraordinária riqueza. Por meio dessa experimentação, eles puderam continuar inseridos no universo político da comunidade, uma vez que visavam escrever sua história chicana. Eles conseguiram, com isso, um resultado positivo gerando um capital linguístico dinamizado por um valor cultural que os identificava como etnia diferente, como a "nova consciência", defendida por Anzaldúa.

A autora mostra esse feito quando leva a público o jeito de se comunicar com irmãos e amigos, e quando, ao mesmo tempo, refere-se a essa trajetória da seguinte maneira: no trabalho e na escola adotou o inglês padrão; com a avó e para ler literatura mexicana e espanhola adotou o espanhol padrão e o espanhol mexicano padrão; para aqueles que 
"chegaram agora", com os imigrantes mexicanos e com os "braceros", teve que aprender o dialeto do Norte do México; com os mexicanos, ela tenta se comunicar usando o espanhol mexicano padrão ou o dialeto do Norte do México; e, com os parentes que moram no Vale, com a mãe, com o "irmão mais novo (que se casou com uma mexicana e raramente mistura o espanhol com o inglês), com as tias e outros parentes", ela usa o espanhol chicano texano [younger brother (who married a Mexican and who rarely mixes Spanish with English), aunts and older relatives] (1999, p. 78). Sob esse signo de experiências, podemos atestar a não amarração de um sujeito a uma única linguagem, mas sim, o fato de ele adotar uma abertura que o impulsione em direção ao ilimitado da linguagem.

Por isso, não é incomum encontrarmos na obra de Anzaldúa, afirmações como a seguinte:

Então, se você realmente quer me magoar, fale mal de minha língua. A identidade étnica está atada à identidade lingüística - eu sou minha língua.

Enquanto eu não puder me orgulhar de minha língua, não posso me orgulhar de mim mesma. Enquanto não puder aceitar como legítimos o espanhol chicano do Texas, o Tex-Mex e todas as outras línguas que eu falo, eu não posso aceitar a legitimidade de mim mesma. Enquanto não for livre para escrever como bilíngue e para trocar de código sem precisar traduzi-los sempre, enquanto eu ainda tiver de falar inglês ou espanhol quando eu preferiria falar spanglish, e enquanto eu tiver de adaptar-me aos falantes de inglês ao invés de fazê-los se adaptarem a mim, minha língua será ilegítima. $\left(1999\right.$, p.81) ${ }^{3}$

Não há, portanto, como duvidarmos desse entrelaçamento de palavras que nos faz perceber o extenso debate com o qual os chicanos se confrontam para poderem enfrentar e resistir à degradação linguística e firmarem o seu modo de falar, o seu modo de viver.

Dessa forma, podemos ligar essas considerações feitas por Anzaldúa à sua tomada de posição, uma vez que a autora nos demonstra uma mediação entre ela e a realidade objetiva, substancializando significados para exprimirem a função social desempenhada pela etnia. Anzaldúa hierarquiza, com sua trajetória, a autoridade emancipatória de narrar sobre o vazio histórico dos chicanos e constrói, nesses instantes, os mitos fundadores descrevendo a construção de uma nova história chicana. 
Talvez pudéssemos aproximar esse fenômeno daquilo que Yúdice chama de "poder cultural", termo escolhido por ele "para expressar a extensão do biopoder na era da globalização", e também, por ser "uma das razões principais pelas quais a política cultural tornou-se fator visível para repensar os acordos coletivos [...]”. Para Yúdice, a conjunção entre "emancipação" e "regulação" é a "expressão clara da conveniência da cultura. Ela é utilizada para resolver uma série de problemas para a comunidade, que parece só ser capaz de se reconhecer na cultura [...]" (2004, p. 45-46).

Por essas razões mobilizadoras, Anzaldúa compartilha com seus irmãos sentimentos de repensar seu caminho. Ela se organiza para reiterar uma nova norma ou conjunto de normas que possam ajudá-la nesse novo território.

Esta é a hora de afirmarmos, portanto, que Anzaldúa e Gómez-Peña qualificam sua política de identidade promovendo trabalhos para que possam focalizar a cultura nativa e suas tradições.

O mais efetivo dos propósitos de Gómez-Peña, por exemplo, foi ter criado uma arte polêmica para refletir acerca da transformação cultural vivenciada pelos chicanos. Com sua arte performática, ele desbloqueia compreensões impenetráveis e nos alimenta com uma espécie de força que, cada vez mais, penetra nos modelos sociais para escrever sobre as diferenças e para denunciar o que está acontecendo com a sociedade chicana.

Ele não apenas reinterpreta as diferenças culturais existentes entre a cultura anglo e a chicana, sequer traça somente representatividades e classificações a respeito de identidades, ou, tampouco, examina de forma superficializada assuntos da vida diária. Ao contrário, de posse de sua autonomia para relatar o que quer, como quer, ele examina o que há por baixo de camadas ideológicas e de estruturas sociais.

Dessa forma, Gómez-Peña e Anzaldúa apresentam uma conscientização que se enquadra no que Yúdice chama de performatividade. Para Yúdice, o termo 
se refere ao processo pelos quais identidades e entidades de realidade social são constituídas pelas repetidas aproximações dos modelos (ou seja, o normativo), bem como por aqueles "resíduos" ("exclusões constitutivas") que são insuficientes. [...] Performatividade, como elaborada por Butler, sugere que, ao invés de leis fundamentais, muitos princípios diferentes de inclusão e exclusão se disputam. (2004, p. 53-54)

Dessa forma, o sentimento ativista impulsionando os autores sempre em direção a uma nova consciência cultural, permite ao leitor reconhecê-los como autores que endossam a questão de resistência, de afirmação e da luta contra o opressor. Pelas letras, eles desenvolvem táticas políticas confrontando opressores (governo, instituições ou pensamentos hegemônicos), como forma de apresentar razões para não neutralizarem a emergência da identidade chicana. E por meio de ações políticas intermediadas pelo artístico/literário, eles se colocam frente a negociações políticas em âmbito institucionalizado: Anzaldúa foi professora universitária, e Gómez-Peña dá aulas de teatro.

Impondo-se por esse tipo de inovação, Gómez-Peña e Anzaldúa adotam estratégias para ultrapassarem fronteiras e se identificam com uma reestruturação cultural que passa pela necessidade de apresentar novas alternativas. Se, para ele, "como artistas transnacionalizados, nosso desafio é recompor a fragmentada crônica desse estranho fenômeno de fim-de-século" [“As transnationalized artists, our challenge is to recompose the fragmented chronicle of this strange end-of-the-century phenomenon”.] (1996, p. 178), para Anzaldúa,

\footnotetext{
Com aquele reconhecimento, nós nos tornáramos um povo distinto. Alguma coisa importantíssima acontecia à alma chicana - ficáramos cientes de nossa realidade e adquirimos um nome e uma língua (o espanhol chicano) que refletia aquela realidade. Agora que tínhamos um nome, alguns dos fragmentados pedaços começavam a se juntar - quem éramos, o que éramos, como tínhamos evoluído. Tínhamos começado a perceber no que eventualmente poderíamos nos tornar. $(1999, \text { p. } 85)^{4}$.
}

Com essas afirmações, os autores dão o exemplo de terem atingido suas metas ao reivindicarem seus direitos como cidadãos e ao demonstrarem que, o mais importante, hoje, é diluir fronteiras, redefinir conceitos para o entendimento de diferenças e se reintegrar nas coletividades marginalizadas no âmbito do aceitável socialmente. Eles representam uma 
possibilidade heterogênea que transforma antigas modalidades e combatem a velha discursividade com um trabalho refletindo sobre formas que inventam outras maneiras de se interrogar as vivências experienciadas.

A ideologia que pregava uma homogeneidade usando a mesma língua, a mesma religião e as mesmas práticas culturais desapareceu quando etnias emergentes construíram a noção de heterogeneidade que foi, na maioria das vezes, desprezada pela cultura hegemônica. Isso foi verificado nos Estados Unidos, por exemplo, quando os hispânicos começaram a promover a língua espanhola e suas variantes "impuras", tais como o Tex-Mex, o Caló, o Spanglish. Os hispânicos criaram uma arte poderosa que acabou por se tornar uma forma para eles se colocarem.

Esse ponto central sugere, a propósito, a formação do que Soja reconhece como o terceiro espaço, ou seja, a "recombinação" e a "extensão" de modos, processos, sistemas, culturas de um primeiro espaço, real, perspectivizado pelas representações imagéticas de um segundo espaço, (re)interpretando aquele imaginado espacialmente (1996, p. 6).

Diante disso, a independência estética toma conta de pensamentos para renovar o diálogo com as contradições do presente a fim de que se exponha, ainda de acordo com Soja (1996), a "transdisciplinaridade" dinamizada pela tripla dialética do histórico/sócio/espacial. Para ele, há abundantes perspectivas com as quais se pode lidar para se atualizar as complexidades do mundo moderno formuladas por suas histórias, suas sociedades e seus espaços. Entre resistir à agonia das mudanças que só fazem tornar ainda mais denso o sofrimento, ele sugere que se aceite ou se tome emprestado esse Outro que não se sabe ao certo "quem" é, mas que, ao mesmo tempo, nos invade, transpõe qualquer uma de nossas fronteiras física, intelectual ou vivida, para resultar, enfim, no citado terceiro espaço, naquele "entrelugar" concebido e formador de novas consciências históricas, sociais e/ou espaciais. 
Apenas dessa forma é possível entender que "liberdade" é o "espaço" onde se

produzem trocas entre as coletividades e onde se intercambia o resultado dessa produção de forma compartilhada por todos. O direito a essa propriedade acontece no momento em que se mesclam elementos adquiridos com a transculturação.

Os chicanos experimentam e combinam um grande repertório, e os Estados Unidos da América possibilitam que esse reconhecimento seja trabalhado na conhecida movimentação do mundo pós-moderno.

\section{NOTAS}

1- Consideremos memória o saber discursivo que substancializa o vazio de um pré-texto ao texto manifesto. Para isso é necessário que consideremos, também, a interpelação do sujeito pela linguagem, pois, para falar, ele precisa ser afetado pela língua. E mesmo assim, para que as palavras desse sujeito façam sentido, é necessário que elas já tenham sentido fora dele. Dizemos, então, que esse sujeito é determinado pelo interdiscurso, ou melhor, pela memória do dizer, por aquilo que já foi falado antes dele em algum outro lugar. Seria, digamos, o envolvimento do sujeito não apenas com a memória literária, mas, ainda, com a memória cultural. (Achard, 1999)

2- Devemos entender testemunho como uma determinada produção textual em luta para que a individualidade original de cada sujeito não seja perdida. Nesse processo, um projeto revolucionário dessa produção tenta uma forma de eliminar a repressão e a dominação advindas da modernidade capitalista e, em consequência, resistir e sobreviver autolegitimando-se culturalmente. "Esses textos enfocam as maneiras em que diversos grupos oprimidos [...] praticam sua identidade não só como resistência à opressão, mas também como cultura afirmativa, como estética prática". (YÚDICE, apud MOREIRAS, 2001, p. 370)

3- "So, if you want to really hurt me, talk badly about my language. Ethnic identity is twin skin to linguistic identity - I am my language. Until I can take pride in my language, I cannot take pride in myself. Until I can accept as legitimate Chicano Texas Spanish, Tex-Mex and all the other languages I speak, I cannot accept the legitimacy of myself. Until I am free to write bilingually and to switch codes without having always to translate, while I still have to speak English or Spanish when I would rather speak Spanglish, and as long as I have to accommodate the English speakers rather than having them accommodate me, my tongue will be illegitimate". (ANZALDÚA, 1999, p.81)

4- "With that recognition, we became a distinct people. Something momentous happened to the Chicano soul - we became aware of our reality and acquired a name and a language (Chicano Spanish) that reflected that reality. Now that we had a name, some of the fragmented pieces began to fall together who we were, what we were, how we had evolved. We began to get glimpses of what we might eventually become". (ANZALDÚA, 1999, p. 85) 


\section{A figura do desaparecido: o resgate do passado ativo}

No processo histórico, fica claro que o choque entre as culturas anglo e espanhola, a incerteza da posição assumida como sujeito literário, o abandono do cânone estabelecido pelo centro europeu e o emaranhado dos vários diálogos em sua narrativização levam-nos à apropriação de um material simbólico que nos é dado por metaforizações e por meio de testemunhos expressos tanto por Anzaldúa quanto por Gómez-Peña quando falam de sua Raza, dos mestizos, do hybrid people.

Como motivo de orgulho e resistência, os autores constroem uma identidade cuja originalidade está em unir suas heranças pré-colombianas à nova consciência nacional. É a edificação da imagem que funciona como um dispositivo para comunicar o tempo vivido e a emergência da Raza; o poder que opera o acordo dos olhares conferindo o quadro da história chicana. O seguinte fragmento apresenta o que acabamos de afirmar:

Realmente não há nenhum enredo, nem “personagens" reconhecíveis. Os intérpretes no palco são imagens e verdadeiros clones virtuais de nossas próprias identidades (ficcionalizadas). Suas vozes são descorporificadas, e suas/nossas ações se tornaram totalmente ritualizadas e anti-teatralizadas. (GÓMEZ-PEÑA. 1996, p. 21) ${ }^{1}$

Como podemos perceber, os relatos de Gómez-Peña e Anzaldúa realizam, a um só tempo, um tipo de intertextualidade, revolvendo narrativas que se encontravam confortavelmente aplicadas em historicidades. Eles transitam pela narratividade pós-moderna com tamanha ousadia que, com esses tipos de textos, assumem potencialidades para configurarem uma condição intertextual levando-os a narrar sobre um verdadeiro coletivo intercultural circundado pela memória. O espaço representado em suas obras é indicador de suas comunidades e passa, portanto, a figurativizar a história dos mexicanos e sua saga nos Estados Unidos, formando sujeitos que vivem no que Gómez-Peña chamou de "Quarto Mundo". O autor afirma que, 
Eu também oponho a velha dicotomia colonial do Primeiro Mundo/Terceiro Mundo à mais pertinente noção do Quarto Mundo - um lugar conceitual onde os povos indígenas encontram-se com as comunidades diaspóricas. No Quarto Mundo, há pouco espaço para identidades estáticas, nacionalidades fixas, linguagens "puras", ou tradições culturais sagradas. Os membros do Quarto Mundo vivem entre e no cruzamento de várias culturas, comunidades e países. E nossas identidades estão constantemente sendo reconfiguradas por essa experiência caleidoscópica. Os artistas e escritores que habitam o Quarto Mundo têm uma tarefa muito importante: elaborar o novo cenário dos mitos, metáforas, e símbolos que nos situarão dentro de todas essas cartografias flutuantes. $(1996, \text { p. } 7)^{2}$

O discurso ${ }^{3}$ e o testemunho que se afiguram nessas narrativas não são, portanto, coisas díspares; entre uma consciência e outra, existem elementos de um mesmo fragmento. Percebemos o discurso sendo gerado pelo testemunho e vice-versa; corpo e alma compondo a estrutura dessa nova roupagem. Ao contrário da concepção canônica, o sujeito gramatical, consciente, divide espaço com o sujeito da enunciação.

E, por meio dessas instâncias contraditórias e antagônicas, surgem personagens que produzem uma unidade de expectativas políticas enunciadas em discursos passados. Nos textos de autores chicanos, uma dessas personagens é retomada e traduzida como a "traidora" do povo asteca e como aquela que deu origem ao hibridismo cultural chicano da América Central: La Malinche ou La Chingada.

Considerada uma figura enigmática, alguns têm-na até mesmo como o próprio enigma. La Malinche ao mesmo tempo que incita, repele; ao mesmo tempo que esconde a morte, oferece a vida. Tendo servido como tradutora para o colonizador Cortez, mais tarde Malinche tornou-se sua amante e concedeu-lhe um filho, cuja descendência representará os filhos traídos, ou aqueles filhos abandonados à própria sorte. Malinche aproveitou-se da condição de esposa de Cortez para entregar-lhe os segredos sociais, culturais e religiosos do povo asteca como uma forma de traição sem precedentes. Segundo Paz,

Toda a angustiosa tensão que nos habita se expressa em uma frase que nos vem à boca quando a cólera, a alegria ou o entusiasmo levam-nos a exaltar nossa condição de mexicanos: Viva o México, filhos da Chingada! Verdadeiro grito de guerra, carregado de uma eletricidade particular, esta frase é um desafio e uma afirmação, um disparo dirigido contra um inimigo imaginário, e uma explosão no ar. (1997, p. 98) 
E mais: por meio de intervenções discursivas, La chingada recobre várias partes do Continente Americano derivando e tendo outros significados. Chingaste, por exemplo, pode significar "semente de hortaliça"; em algumas regiões da Espanha, o mesmo vocábulo está associado a determinadas bebidas alcoólicas, e chinga quer dizer "beber demasiado". Chinguere pode significar álcool; em países como o Equador, Chile e Peru, o termo chingana equivale a taberna; e em Cuba, chinguirito é o mesmo que um gole de álcool (PAZ, 1997, p. 99).

Uma outra possibilidade leva-nos a decodificar chingar como uma ideia de fracasso, além da ideia de zombaria. Ainda segundo Paz, "É um verbo agressivo, como pode ver-se por todas essas significações [...] No México, os significados da palavra são inumeráveis. É uma voz mágica. Basta uma troca no tom, uma inflexão apenas, para que o sentido varie” (1997, p. 99).

E este sentido modifica-se no momento em que, ao invés de distinguir La Malinche como aquela nada digna de confiança e a traidora do povo, a vemos como a mediadora cultural determinando o nascimento da cultura mexicana e das diferenças resultantes dessa cultura com a chegada dos espanhóis.

Como sujeito migrante e fronteiriço, La Malinche poderia circular nos dois espaços: no espanhol e no indígena. Apropriar-se dos espaços de representação dessas culturas não foi tarefa fácil para ela. Mas essa mulher conseguiu adquirir e unir o espaço nacional bilíngue e transformá-lo na lendária conotação bicultural, transnacional. Sem ser órfã de seu passado, ela passa a produzir e representar aquela personagem indo e vindo pelas zonas de fronteira das duas culturas, mostrando que estas estão sempre em movimento e nunca fixadas de uma única maneira e, tampouco, estáticas.

O interessante é observarmos que algumas chicanas legitimadas como autoras têm feito questão de serem reconhecidas como ativistas sexuais e feministas e lutam para 
definirem-se como bilíngues, bissexuais, lésbicas e não simplesmente como as mexicanas, ou as norte-americanas chicanizadas. Elas trabalham e convivem com o transpor das fronteiras nacionais do México ou dos Estados Unidos da América para, de forma recorrente, apropriarem-se e reinterpretarem ambos os mitos de identidade nacional femininos: la Malinche e a Virgem de Guadalupe (a sacrificada).

De uma maneira ou de outra, as novas "malinches" lutadoras têm recorrido a diversas outras estratégias para fazerem surgir e defender sua própria subjetividade mesclada que está, agora, com aspectos da cultura mexicana e estadunidense. Elas conseguiram, de forma notável, converter o momento político no qual estão vivendo em sua estratégia de luta. Mais do que simplesmente ser mexicana ou falar em espanhol, as novas "malinches" souberam estabelecer e fazer respeitar as diferenças coloniais que carregam consigo, bem como o diferencial étnico e de classe já assimilados durante todas essas décadas de lutas e de conflitos.

Podemos perceber que os chicanos lutam contra uma realidade fantasmagórica cujos fantasmas encontram-se engendrados neles mesmos. Acreditam que estes fantasmas sejam vestígios de realidades vivenciadas no passado e que, por isso mesmo, incute-lhes um verdadeiro medo de ser um povo, de ser chicano. Vejamos os comentários de Anzaldúa e Gómez-Peña a esse respeito:

\footnotetext{
Nós temos medo de sermos abandonados pela mãe, pela cultura, pela Raza, de não sermos aceitos, de falhar, sermos prejudicados. A maioria de nós acredita inconscientemente que se revelarmos esse aspecto inaceitável do self, seremos rejeitados totalmente pela mãe/cultura/raça. (ANZALDÚA, 1999, p. 42$)^{4}$.

O medo está sempre no centro da xenofobia. Esse medo é sempre perturbador quando direcionado às vítimas mais vulneráveis: os trabalhadores imigrantes. Eles transformam-se nos "invasores" do Sul, a encarnação humana da mosca mexicana, a "wetbacks" molhada do sub-humano, o "alienígena" de um outro planeta (cultural). (GÓMEZ-PEÑA, 1996, p.67)
} 
Com essas afirmações, é como se os autores não quisessem ou não se atrevessem a ser eles mesmos. Eles têm a nítida sensação de não poderem contar com a história a fim de esclarecer-lhes a origem desses fantasmas. Entretanto, Anzaldúa e Gómez-Peña têm a certeza de que a história não conseguirá dissipá-los, pois, de uma forma ou de outra, a verdade sobre a história chicana tem de ser inventada todos os dias. Eles, chicanos, padecem de um delito sem nome e do qual não tiveram culpa: o de ter assumido uma posição política que os transformou e os caracterizou como chicanos. Nesse sentido, podemos pensar que a relação dos autores com o mundo define-se como uma busca incessante de transcender o estado de exílio no qual encontram-se enraizados. Gómez-Peña e Anzaldúa têm consciência de sua solidão histórica e pessoal.

Talvez seja essa a razão de a linguagem da interpretação precisar ir além daquele olhar crítico horizontal para poder narrar sobre a memória histórica chicana, vivenciada na subjetivação de seus ideais como povo. A experiência individual vivida pelos chicanos não deixa de envolver o contar da própria coletividade. Em suas discussões como uma nação de descendência asteca, a força cultural aparece como aparato de um poder simbólico representado em alegorias discursivisadas na atualidade.

Portanto, que formulações discursivas enunciam-se de maneira tão diferente em tantas outras épocas da história da arte de falar, que ainda intriga-nos saber quem fala no universo textual? Além do mais, estas formulações também deixam-nos inferir que uma série de outros caminhos pode ser tomada quando se quer trabalhar com essa difusa fragmentação.

Assim, o argumento que teríamos para recobrir boa parte da manobra retórica a fim de estabelecermos a voz vencedora nos jogos textuais, demonstra que o funcionamento das narrativas contando sobre a tradição e sobre o passado, é o processo por meio do qual essas conjecturas se organizam para expressar a realidade contida na narrativização daquele que se dispõe a empreender tarefa tão radical. 
Poderíamos nos perguntar o que é preciso decifrar no espaço em branco da expressividade para concebermos a estranha voz por debaixo da superfície textual contando sobre esta ou aquela nação/cultura e como as mesmas acontecem.

Provavelmente, essa expressividade venha de um outro lugar situado para "além" do texto, pois, a "falta" de se escrever sobre ela, se acontece, é dada por interdição. E se isso ocorre, é porque toda uma formação discursiva foi silenciada, interditada, excluída. É como se não houvesse memória, impedindo que certos sentidos, hoje, gerassem outros.

Como podemos verificar, o sujeito discursivo chicano passa a desestabilizar a significativa rede do que sempre foi comunicado e estende suas posições em exemplos marcantes de novas especificidades discursivas agenciadas por ele mesmo. Um outro significado embutido nesse sujeito completa a reconstrução da imensa rede de significâncias e o novo significado acompanha o sujeito que pode, assim, manifestar-se por meio de linguagens renovadoras. Supondo que essas questões sejam consideradas, ao conceituar sujeito, não devemos nos esquecer de que esse denso significante passa pelo crivo de um discurso, dito discursivização, e costuma autorizar significações fazendo-nos argumentar sobre determinadas incompreensões. Nesse sentido, uma vez que ninguém, ao querer interpretar um dado fenômeno, está vazio intelectualmente ${ }^{6}$ de alguma especificação para problemas envolvendo referentes, ou, se está, procura, no mínimo, preencher esse vazio com especificidades que, talvez, somente a intelectualidade não dê conta, apela para outras formas de teorizações.

Como podemos explicar, portanto, esse sujeito que deixa transparecer a expressão de vozes discursivas presentes nas subjetividades ${ }^{7}$ históricas indicativas de um lugar vazio? Como apresentaríamos essa exterioridade desconhecida, manifestando-se por meio de um locus enunciativo que derruba a condição de autoritarismo compromissado com o poder narrativo? 
Ora, no caso presente da cultura chicana, há uma multiplicidade de mundos narrados e uma alegorização que une a tipologia histórica chicana a uma imaginação criadora, uma vez que se concebe a pluralidade textual entre relatar sobre a história dos chicanos e o narrar imagético marcando a experiência subjetivada de toda uma memória historicizada. A transformação física do patrimônio territorial confirmando que nem o passado e tampouco o presente se encontram terminados, apresentam partes do intertexto perpetuado nas implicações culturais que levam a memória de um povo a expressar-se por meio de objetos relacionados com o mundo artístico e intelectual. Segundo Bhabha,

\footnotetext{
O pacto da interpretação nunca é simplesmente um ato de comunicação entre o Eu e o Você designados no enunciado. A produção de sentido requer que esses dois lugares sejam mobilizados na passagem por um Terceiro Espaço, que representa tanto as condições gerais da linguagem quanto a implicação específica do enunciado em uma estratégia performativa e institucional da qual ela não pode, em si, ter consciência. O que essa relação inconsciente introduz é uma ambivalência no ato da interpretação. (1998, p. 66)
}

A questão não é apenas "na passagem para um Terceiro Espaço", mas como os direitos de um povo devem ser reivindicados para se constituírem em uma "identidade". A nosso ver, os chicanos têm desenvolvido um diálogo que nunca é visto apenas como igualdade, mas aquele caracterizado pela hierarquia da transculturação (Reis, 2005). Eles têm, por um lado, falado explicitamente por meio de uma mensagem que ainda não tinha sido dita de maneira tão aberta - Anzaldúa comenta que é uma mulher de duas culturas, a anglo e a mexicana, sendo que desta última herdou as várias linguagens faladas pelos astecas - e, por outro, vão denunciando pela transgressão, aquilo que para muitos ainda não poderia ser dito.

Ao traçar a formação da "consciência mestiça", por exemplo, a autora enfoca os diversos grupos que se misturaram e resultaram no que hoje é chamado "chicano". Ao longo de sua narrativização, a história chicana é traçada como aquela de variados e múltiplos encontros, não somente das etnias mexicanas, mas, certamente, das culturas e suas economias distintas em movimentos e choques permanentes. Parece que das várias transculturações 
marcando a história do México, nenhuma tem sido tão forte e cruel como a dos chicanos, pois, ao serem transplantados de forma espaciotemporal, foram e são cortados em suas raízes.

Em consequência, a estetização do patrimônio cultural chicano pode ser apreciada nas dificuldades para se compreender os atormentados períodos de inquietação pelos quais os chicanos passaram, além de lhes ter sido tirada a própria possibilidade de continuarem sendo a tradição de uma Raza independente.

Subtraídos no início de sua identidade nacional pela invasão dos espanhóis durante mais ou menos três séculos, em 1848 os mexicanos perceberam-se transferidos da hegemonia espanhola para a dos Estados Unidos. Sua herança pré-colombiana e sua consciência nacional tornaram-se, nestes termos, bastante ameaçadas. Assim os chicanos se sentem nos Estados Unidos: eles nascem com um hibridismo sócio-cultural e linguístico e nunca mais sentir-se-ão geograficamente situados em um único espaço. Eles se verão separados por meio de diversas fronteiras, inclusive as nacionais e as políticas, tanto que estas características estão expressas na resistência à cultura espanhola e também à cultura anglo-americana.

O trabalho que resulta desse movimento transformador propõe, por isso mesmo, que observemos as oportunidades e os novos aspectos que vão surgindo com essa sobreprodução circunscrita em complexas redes inter-relacionadas umas às outras. Por essa combinação de opostos, além da transformação de problemas e respostas apresentados por todo o campo das produções estéticas gerando um produto de articulação literária, encontram-se os impasses e as questões de um pós-escrito, ou melhor dizendo, as características de uma ficção pósmoderna, observadas nas várias articulações narrativizadas em prosa e verso dos textos em estudo. Buscarmos nos textos de Anzaldúa e Gómez-Peña aspectos para pensarmos a pósmodernidade é estar à procura da historicidade significativa sobre o que possa ser "verdade" histórica. O ingresso nesse desequilibrado mundo veridictório ${ }^{8}$, corresponde a um gesto 
desorganizado de se dizer, não o que verdadeiramente somos, mas no que supostamente nos tornamos.

Dessa forma, os arranjos expressivos desencadeados como recurso utilizado pela enunciação nas "falas" dos escritores fazem do sujeito concretizado em suas personagens um percurso de fazer persuasivo que leva o leitor a se dispor em credibilidades e aceitar o que foi dito. Para isso, o leitor reserva-se o direito de estabelecer um contrato fiduciário ${ }^{9}$ para organizar as estruturas modais presentes na semiótica dos discursos e estabelecer os valores contratuais a fim de aceitar não a "verdade", mas um "dizer-verdadeiro" que o sujeito enunciador construiu durante toda a manifestação de competência transformadora nas marcas e pistas deixadas implicitamente ao longo de seu discurso.

Se levarmos em conta que a memória, em si, é a condição do dizível, em consequência, os sentidos do que é tradição não poderiam ser lidos sem aquela, pois, memória e tradição são indissociáveis. Ou melhor, se tentarmos buscar as origens expressivas para apreendermos o sentido equivalente compondo os traços da representação do tradicional, muitas vezes nos deparamos com uma memória cultural que se recusa a permanecer reprimida. O que foi recusado antes não desaparece por completo. Permanecem alguns vestígios; vestígios de discurso em suspenso que demandam uma relação entre o que foi narrado anteriormente e o que poderá ser motivo de novas narrações. E se é assim, por onde passa o sentido da repressão, o sentido de ser uma tradição milenar, o sentido de ser subjugado a ela?

Ao escrever sobre essas contradições, muitas teorias baseiam-se em uma unidade que é alcançada não com a eliminação das diferenças, mas por meio das oposições que se precisam e se especificam no comportamento adotado pelos membros do grupo, pois falamos em comportamento não como uma simples constituição psicológica, desencadeadora de atos individuais, mas como a estrutura sistematizada na qual as formas de uma tradição cultural 
encontram-se articuladas. Dependerá das técnicas empregadas pelo autor implícito a capacidade de qualquer escritura despertar e manter o interesse enquanto discurso produzido.

Inferimos, a partir daí, que a interpretação tanto quanto a observação fazem todo o caminho da construção teórica, pois, ao remodelarmos pela escrita determinados padrões encontrados nas relações tradicionalmente sociais, estamos reordenando as coisas de um mundo experimentado. Sendo assim, não faltam referências nem na escrita de Anzaldúa e tampouco na de Gómez-Peña construindo a identidade e a história chicanas. Este último faz o seguinte comentário:

A identidade mexicana (ou melhor dizendo, as muitas identidades mexicanas) não pode mais ser explicada sem a experiência de "o outro lado", e vice-versa. Como um fenômeno sócio-cultural, Los Angeles simplesmente não pode ser entendido sem levar a Cidade do México - seu vizinho mais sulista - em conta. Entre ambas as cidades corre o maior eixo migratório sobre o planeta, e a rodovia conceitual de liberdade com o maior número de acidentes. $\left(1996\right.$, p. 178) ${ }^{10}$

E Anzaldúa declara que:

Não obstante a luta por identidades continue, a luta de fronteiras ainda é nossa realidade. Um dia, a luta mais interna terminará e uma verdadeira integração acontecerá. Enquanto isso, temos de lutar. Quem está protegendo o rancho de minha gente? Quem está tratando de fechar a fissura entre a indígena e o branco em nosso sangue? O chicano, sim, o chicano que anda como um ladrão em sua própria casa. $(1999, \text { p. } 85)^{11}$

Nesse sentido, podemos sustentar que, ao tomarmos por base os artifícios enunciativos atestando a polifonia discursiva, o conjunto de acontecimentos descritivos fica na mira de uma instância autônoma dada por um certo enunciador que faz surgir uma voz implícita que comanda o processo por via das imagens visualizadas do verbal. Ao analisar o aparato referencial dos fragmentos e da sequencialização, esse enunciador traz, para o universo considerado, a grande importância da tradição segundo seu ponto de vista.

Acontece, assim, de as tradições fazerem-nos sentir as dificuldades de transições enfrentadas por qualquer raça que busque crenças em autonomias individuais. É preciso que percebamos a significância, que nosso desejo realiza, de compreendermos o valor das 
narrativas e das estruturas do tradicional, discursivamente legitimadas para que ela

(significância) dê conta das complexas conexões existentes entre o antigo e o novo, entre a tradição e o pós-moderno.

Esse trabalho diferenciador exige, portanto, que o discurso cultural não retome o passado simplesmente, mas que, na inscrição de signos para estabelecer a memória cultural, dê conta de reconfigurá-lo, renovando-o como um "entrelugar ". Assim, a noção do novo sobrevive para operar nos interstícios da prática discursiva e, mais uma vez, o reconhecimento do passado histórico encena identidades, recriando o reestabelecimento de comunidades fronteiriças.

\section{NOTAS}

1- "There is really no plot, nor recognizable "characters". The performers on stage are mere media images and virtual reality clones of our own (fictionalized) identities. Their voices are disembodied, and their/our actions have become totally ritualized and antitheatrical”. (GÓMEZ-PEÑA, 1996, p. 21)

2- "I also oppose the old colonial dichotomy of First World/ Third world with the more pertinent notion of the Fourth World - a conceptual place where the indigenous people meet with the diasporic communities. In the Fourth World, there is very little place for static identities, fixed nacionalities, "pure" languages, or sacred cultural traditions. The members of the Fourth World live between and across various cultures, communities, and countries. And our identities are constantly being reshaped by this kaleidoscopic experience. The artists and writers who inhabit the Fourth World have a very important role: to elaborate the new set of myths, metaphors, and symbols that will locate us within all of these fluctuating cartographies ". (GÓMEZ-PEÑA, 1996, p.7)

3- Os discursos materializam as "visões de mundo das diferentes classes sociais, com seus interesses antagônicos, os quais se manifestam através de um estoque de palavras e de regras combinatórias que constituem a maneira de uma determinada classe social pensar o mundo num determinado momento histórico: são as várias formações ideológicas correspondentes às várias formações discursivas". (BACCEGA, 2003, p.52)

4- "We're afraid of being abandoned by the mother, the culture, la Raza, for being unacceptable, faulty, damaged. Most of us unconsciously believe that if we reveal this unacceptable aspect of the self our mother/culture/race will totally reject us". (ANZALDÚA, 1999, p. 42)

5- "Fear is always at the core of xenophobia. This fear is particularly disturbing when directed at the most vulnerable victims: migrant workers. They become the "invaders" from the South, the human incarnation of the Mexican fly, subhuman "wetbacks", the "alien" from another (cultural) planet". (GÓMEZ-PEÑA, 1996, p. 67)

6- "Intelectual é, não quem pensa o mundo, mas aquele que tem o poder de comunicar o que pensa sobre o mundo. Não um homem de 'idéias e valores' mas da comunicação: não aquele que pensa senão aquele que torna público o que pensa”. (RINCÓN, 1995, p.53) 
7- Ao citar Freud para dizer da subjetividade, Hall conclui que esta "é o produto de processos psíquicos inconscientes". (2003, p. 37) A fim de esclarecermos o termo, poderíamos acrescentar a ideia de que subjetividade, para muitos teóricos contemporâneos, envolve uma pré-condição estrutural de dizê-la como o resultado discursivo desenvolvido por determinadas ideologias. Assim, ela não é uma entidade empírica, mas alguma coisa desenvolvida pelos atos da fala, resultante da ideia que envolve "jogos de linguagem” em atenção a relações sócio-culturais preestabelecidas ao longo da história humana.

8- Segundo Fiorin (2001), podemos dizer que o enunciador discursivo não produz discursos verdadeiros ou falsos, mas fabrica discursos que tendem a criar efeitos de verdade ou de falsidade, que parecem falsos ou verdadeiros e, como tais, devem ser interpretados. O que surge são valores apreendidos e pretensamente expressos em forma de temas. Estes, ao longo do percurso discursivo, são investidos de maneira figurativizada e são reconhecidos a partir daí, como "veridicção" ou "dizer-verdadeiro" que corresponderia ao "crer-verdadeiro", mesmo enquanto ficção. É dele que boa parte dos efeitos narrativos reconhecidos como surpresa, suspense, enveredamento temporário, relacionam-se para poder criar as condições expressivas que se darão tanto no desenvolvimento da narrativa quanto na aplicabilidade de uma leitura pertencente a um processo de transmutação debruçado, inevitavelmente, no "acontecimento" narrado. Assim, um determinado número de procedimentos codificados pelo enunciador, a serem apresentados no enunciado textual, manifesta-se como um tipo de produção e invenção, dos quais ele se utiliza para intensificar o desenvolvimento do mundo ficcional já existente no imaginário.

9- De acordo com Greimas e Courtés (1979), o termo de origem jurídica merece alguma atenção uma vez que nós podemos nos apropriar dele para empregá-lo com sentido distinto. A realização comprometedora dada pela fidúcia (fé ou confiança) daquele que fala é definida na técnica jurídica, como a estipulação da última vontade de um sujeito que tem a intenção de constituir outra pessoa como o herdeiro indicado na herança sucessiva deixada por ele. Segundo o direito romano-germânico, fiduciário seria aquele a quem se obrigaria administrar os bens recebidos de outrem, na condição imposta de repassá-los cumprindo uma finalidade determinada pelo primeiro sujeito. A eficácia da demanda atenderia à consideração de se acreditar que a resolução do problema consistiria no ordenamento circunscrito na doação de uma quota disponível quando o bem fosse transferido novamente, mediante o pagamento, ao seu antigo dono. Assim é estabelecida a dicotomia fidúcia/fiduciário no âmbito do Direito.

Na semiótica greimasiana, o contrato fiduciário enunciativo, virtualmente estabelecido entre enunciador e enunciatário, se pronunciaria por marcas deixadas no enunciado pelo enunciador para fazer crer nas estratégias usadas a constituir o seu discurso, criando o efeito de "verdade" interna do enunciado. O enunciador deixaria transparecer acordos firmados com o enunciatário ao lhe propor um princípio de que o enunciado $A$ deveria ser lido como $A$ para manter a restrição imposta. Na hipótese de um desacordo, o enunciado $A$ deveria ser lido como não- $A$, regendo, dessa maneira, os diferentes mecanismos discursivos empregados na constituição de distintas estratégias de persuasão.

10- "Mexican identity (or better said, the many Mexican identities) can no longer be explained without the experience of "the other side", and vice versa. As a socio-cultural phenomenon, Los Angeles simply cannot be understood without taking Mexico City - its southernmost neighborhood - into account. Between both cities runs the greatest migratory axis on the planet, and the conceptual freeway with the greatest number of accidents". (GÓMEZ-PEÑA, 1996, p. 178)

11- "Yet the struggle of identities continues, the struggle of borders is our reality still. One day the inner struggle will cease and a true integration take place. In the meantime, tenemos que hacerla lucha. Quién está protegiendo los ranchos de mi gente? Quién está tratando de cerrar la fisura entre la india y el blanco en nuestra sangre? El Chicano, sí, el Chicano que anda como un ladrón en su propria casa". (ANZALDÚA, 1999, p. 85) 


\section{A expressão da voz chicana contida nos ditos e escritos de Anzaldúa e Gómez-Peña}

A multiplicidade dos mundos narrados pelos chicanos Guillermo Gómez-Peña (1996) e Gloria Anzaldúa (1999) levam-nos a compartilhar, com eles, de inovações estéticas e de novos valores literários que correspondem a um tipo de reestruturação narratológica desenvolvida nos tempos pós-modernos. Eles narram sobre o desejo de cruzar fronteiras, indagar a si mesmos sobre a angústia de viverem à margem dos valores estabelecidos culturalmente, além de intentarem construir uma identidade nacional cujos signos explicariam o passado e o presente da etnia. Os autores também refletem sobre a existência de diversidades culturais múltiplas, híbridas, dispersas, assim como consideram seus trabalhos ahistóricos, transculturalizados, daí causadores de um forte desconforto.

Anzaldúa e Gómez-Peña navegam também por datas e acontecimentos que nos fazem supor a conflituosa história "local" dos chicanos tanto quanto seus legados de submissão colonial dispersos no imaginário do sistema globalizado.

Por suas polêmicas estruturações (mistura de gêneros formais - prosa/verso, inglês/espanhol/francês, dramatização/diegese), os textos dos referidos autores permitem-nos visualizar uma estética poético/política, quando queremos nos envolver com a questão de quem fala no texto. Sendo assim, quem fala instaura personagens agigantando-se como autênticas figuras críticas entregues a uma pesquisa sócio-cultural e à própria criação literária. $\mathrm{Na}$ verdade, eles aprofundam suas observações sócio-culturais a respeito do México e dos Estados Unidos e argumentam sobre a possibilidade de os diversos loci de observação e de enunciação trazerem suas informações sobre a incerteza resultante da condição de uma póscolonialidade bastante específica da "Raza". 
A respeito das progressivas contradições, os chicanos são os mexicano-americanos nascidos do hibridismo sócio-cultural e linguístico, que não se sentem situados em um único espaço seja ele físico ou não, e realizam vários tipos de "travessia" para outras margens.

Os chicanos veem-se a si mesmos, dessa forma, como aqueles que foram separados por diversas fronteiras, inclusive as nacionalmente políticas, posto que seus ideais estão expressos na resistência à cultura espanhola e à cultura anglo-americana. Ainda segundo Anzaldúa,

com Borderlands, o que mais me surpreendeu foi que a metáfora das fronteiras falou muito mais ao seu tempo do que eu supunha. $\mathrm{O}$ mesmo tem acontecido a um grande número de diferentes pessoas que ensinam em diferentes disciplinas, que estão em diferentes países. Recebi um telefonema até mesmo do Japão, de pessoas que gostariam de que eu explicasse essa metáfora. (2000, p. 5) ${ }^{1}$

Seria interessante lembrarmos que as comunidades chamadas chicanas são compostas por histórias de lutas empreendidas por mexicanos que deixaram o país de origem, migrando para os Estados Unidos. Eles constituíram-se por meio de uma tentativa de mostrar como o transnacionalismo pode tornar-se local e vice-versa e, ao expressarem-se a respeito de mundos tão diferentes e separados pela distância, revelam, também, como podem se unir na afetividade, ou se estranharem nas adversidades. Anzaldúa afirma que as pessoas que mais marginalizam seu trabalho são os próprios chicanos considerando-a apenas como nota de rodapé ou simplesmente nem estudando seu trabalho (p. 7).

Borderlands e The New World Borders, portanto, articulam-se a partir de uma pluralidade de vozes marcando a coexistência de linguagens entre cultura(s), sociedade(s) e história(s) chicana(s) e mostram-nos uma reflexão sobre o novo vocabulário emergente em que "verdade/descentramento", "fronteiras/margens", "local/global”, "dentro/fora", "aqui/lá", revelam problemas cruciais para estudarmos a americanidade chicana. Notamos, então, jogos de linguagens, uma mistura de gêneros e de línguas, indicando o desejo e as paixões na conexão entre personagens e fatos narrados. 
A partir desse horizonte, as estéticas literárias, tanto a do texto de Gómez-Peña quanto a de Anzaldúa, deixam entrever uma ruptura "espacial" singular. Os autores focalizam situações político-econômicas e artístico-sociais do México, concretizadas em discursivizações sobre a fronteira México/Estados Unidos, México/“mundo”, para que percebamos como o relacionamento de apropriação do capital simbólico discursivamente atualizado resulta no (des)centramento de hegemonias estabelecidas como cânone literário. Além disso, eles reconstroem suas experiências artísticas de forma inovadora, uma vez que estas dão prosseguimento às "imagens" culturais criadas no passado. Ao mesmo tempo, Anzaldúa e Gómez-Peña conseguem expor a "voz" chicana, escrevendo sobre a ancestralidade, a linguagem e a cultura dos chicanos.

O fato de os escritores viverem divididos entre duas culturas, duas línguas, duas realidades, é explicitado em textos que expressam uma cumplicidade autoral estabelecida entre enunciador e enunciatário, a fim de que examinemos e visualizemos como suas narrativas formam uma fluência de dizeres de uma cultura em miscigenação. Gómez-Peña e Anzaldúa adotam um emaranhado de vários diálogos em que tanto o discurso oral quanto o escrito produzem uma estrutura temática diferenciada e confrontam estéticas transformando linguagens e sentidos, acreditando terem o direito de continuar produzindo uma escrita mais liberada da estética canônica. Transformam, com isso, a redundância estilística em processos estéticos renovadores, criando uma outra estética literária. Neste ponto, podemos citar as palavras de Mignolo:

O que essas transformações sociais geraram não foi uma nova forma de ciência ou de pensamento filosófico, mas "literatura" produzida ou nas ex-colônias ou às margens dos centros metropolitanos que recebem os maciços movimentos migratórios. (2003, p. 358)

Dessa elaboração surge o que Anzaldúa chama de "herida abierta" (1999, p. 25), ou seja, ela passa a questionar a mestiçagem do povo mexicano, as atrocidades cometidas contra eles pelos espanhóis e, mais tarde, a luta travada com os anglo-americanos, suas terras 
perdidas, a emergência da Raza etc., levando essa Raza à ascensão de posições de luta por uma liberdade individual que traz à baila a denúncia de uma fusão entre o racionalismo tecnológico e a intuição artística.

Em outras palavras, para Anzaldúa, ser a Raza significa ter conseguido quebrar o silêncio a que estava relegada, ter outras qualidades que não as de ladra e desocupada; sentirse como sujeito, e não como objeto de uma conquista. Para ela, a Raza foi formada pela luta para romper tradições oprimidas e com isso torna-se necessário reorganizar formas de falar representadas nas práticas sociais. Segundo ela, os chicanos precisaram transformar suas tradições sociais em uma transculturalização e desconstruir a homogeneidade pretendida por pessoas que fazem uso da mesma prática cultural, da mesma religião, língua e dos mesmos costumes. A Raza culmina, portanto, em um entrelaçamento de formas que expressam o novo contexto contemporâneo. Ainda, de acordo com a autora,

\begin{abstract}
O que estou tentando articular agora é o tipo de uma metizaje, um nos/otras segundo a qual, o nos é nos/nós/mim/o sujeito; o otras é los/eles/o objeto, e no nos/otras nós somos eles e eles são nós, contaminando-nos uns aos outros. É difícil; é como uma corda apertada que se eu der muito espaço à parte eurocêntrica de mim, significa que eu dei as costas para minha raça, os chicanos e mexicanos. Se eu abuso muito desse nacionalismo, então significa que não sou realista, não estive no século XX, convivendo com essas realidades porque para mim não é suficiente ser uma chicana porque também sou sapatão e escritora, sou erudita, tenho estado na escola, nas escolas de brancos toda minha vida, tanto que isso é parte de mim. E claro, negociando com essas duas diferentes nacionalidades tenho me deparado com essa coisa que chamo de novo tribalismo. Tenho tentado não reagir a nenhum dos dois lados, mas agir, ser mais provocativa que reativa, e é difícil de ser feito porque não existem mapas. E muitas vezes não há palavras, e - ou se existem palavras elas estão implicadas num sistema binário do inglês ou do espanhol, e especialmente do espanhol em que a língua tem gênero fixo. $(2000, \text { p.11 })^{2}$
\end{abstract}

Sendo assim, ao polemizar sua escritura por meio da literatura, Anzaldúa expressa como os fatos experienciados de maneira empírica transformam-se em outras vivências. Novas condições culturalizadas dão origem a narrativas enfocando uma espécie de confronto acusador de atrocidades imperialistas. Suas experimentações literárias estão relacionadas a outras vozes até então não ouvidas e a uma rearticulação das diversidades históricas apontadas dentro da própria cultura chicana. Ela conduz a identificações de uma reorganização sóciocultural para entendermos os deslocamentos entre o que foi herdado pela tradição e o que se 
faz inovador. Somente assim a história do grupo pode ser recontada do ponto de vista do conquistado.

A autora deixa transparecer ainda que uma forma de existir ou um fato é criado e recriado de acordo com a época histórica em que se está vivendo. É por basear-se na verossimilhança, e não na "verdade", que a experimentação literária utiliza-se ora da ficção, ora da História, quando não da dessacralização das duas a fim de se construirem outras "verdades". Em consequência dessa maneira de articular, os fatos resultam em uma (re)criação figurativizada pelo próprio emissor do texto. Escrever ou criar de maneira artística é, portanto, uma manifestação do inconsciente tanto quanto o sonho, o ato falho, o chiste e os sintomas o são. O sujeito pensante, no momento da criação, sente-se atropelado por outro sujeito desconhecido que o incomoda e o instiga a produzir. Ele se impõe de forma nada arbitrária e com tanta força, que o primeiro vê-se obrigado a criar. Não é, entretanto, o caso de substituir-se o determinado pelo indeterminado, mas existiria, sim, a elaboração processual de substituir uma ordem, uma sintaxe estruturada, por outra. Anzaldúa aponta que:

\begin{abstract}
A outra maneira de consciência facilita imagens da alma e da inconsciência por meio dos sonhos e da imaginação. Seu trabalho é rotular "ficção", faz-de-conta, realização de desejos. Antropólogos brancos alegam que os indígenas têm mentes "primitivas" e por isso deficientes, que nós não podemos pensar de forma consciente mais elaborada-racionalmente. São fascinados pelo que chamam de mente "mágica", mente "selvagem", a participação mística da mente que dita o mundo da imaginação - o mundo da alma - e o mundo do espírito é apenas tão real quanto a realidade física. $\left(1999\right.$, p. 59) ${ }^{3}$
\end{abstract}

Com isso, ela constrói uma nova consciência mestiça (leia-se "a Raza, o índio melhorado"), vinculando a ideia de sobrevivência dos chicanos a uma capacidade de transformação e de adaptação às quais tiveram de se submeter caso não quisessem ser eliminados completamente do novo lugar em que moram, os Estados Unidos da América. Com a Raza, a autora procura demonstrar o processo no qual os chicanos encontram-se envolvidos para constituírem-se em uma diferença. Embora ela mesma tenha conquistado 
posições sociais por meio de sua literatura, a questão da identidade ainda representa sérios problemas para a autora.

Para Anzaldúa, ser identificada como a "Raza" significa "Somos um povo" ["Somos una gente"] em que "ser povo" é dar voz ao desejo, é querer fazer acordos territoriais e de gênero, querer liderar, ser chicano, empreender quebras de fronteiras, sejam elas quais forem, a fim de usar uma força expressiva para marcar diferentes cartografias (1999, p. 107).

De modo a ultrapassar o âmbito autobiográfico, a autora busca uma voz para lançar um discurso literário/social que alicerce identidades individuais e coletivas, como forma de mostrar as constantes complicações históricas nascidas nas áreas de fronteiras existentes entre o México e os Estados Unidos. O resultado apresenta-se em considerações culturalmente variadas que ela tece com o seguinte comentário no prefácio da obra: "Não é terreno fácil para se viver este lugar de contradições. O ódio, a ira e a exploração campeiam por estas paragens" ["It's not a comfortable territory to live in, this place of contradictions. Hatred, anger and exploitation are the prominent features of this landscape".] (1999, p. 19).

Surge com este testemunho a consciência que evidencia as múltiplas posições assumidas por qualquer autor chicano ou por outra pessoa pertencente ao grupo. Hoje, os chicanos já não falam em uníssono, expressam-se de forma plurissignificante por meio da literatura, do teatro, do grafiti e de diversas outras manifestações, bem como questionam quais enfrentamentos poderiam ter provocado os males sociais sofridos por eles e quais traços dessa colonialidade do poder os têm feito permanecer marginalizados por tanto tempo.

Em confronto com a hegemonia político-social da América do Norte desde o século XVIII, os chicanos consideram-se filhos de uma mistura cultural entre índio mexicano, colonização espanhola e cultura norte-americana em busca da identidade perdida. Descendentes dos índios mexicanos Astecas, os chicanos têm conhecimento de que sua "grande nação" foi dizimada pela invasão espanhola com Hernán Cortés e sabem também 
que, depois de amargarem tantos desencontros como consequência das perseguições, "os mestizos fundaram uma nova raça híbrida e herdaram a América do Sul e a Central. Em 1521 nasceu uma nova raça, o mestiço, o mexicano (povo de mistura de sangue entre indígena e espanhol), uma raça que nunca tinha existido antes", narra Anzaldúa [“The mestizos [...] founded a new hybrid race and inherited Central and South America. Em 1521 nació una nueva raza, el mestizo, el mexicano (people of mixed Indian and Spanish blood) a race that had never existed before".] (1999, p. 27).

Nesta perspectiva, antigas certezas referentes às questões identitárias da cultura chicana irão servir de ponte para que ela se aproprie da "imagem" da Virgem de Guadalupe e transforme seus antigos sentidos em força de seu grito político. Apropriar-se da imagem da Virgem parece indicar o surgimento de um discurso que modifica o poderoso arquétipo feminino de submissão da mulher chicana ao homem. Ora, já não existe a submissão social a este homem e tampouco a passividade política em relação a qualquer homem e, sequer, um lúcido pensamento de submissão ao capitalismo norte-americano. Anzaldúa "sequestra" a Virgem e, de forma subversiva, por meio de seu discurso feminista, comunica-nos suas discussões em torno de gêneros, sexualidade, raça, periferias, culturas. Ao sequestrar e subverter a imagem de Guadalupe, Anzaldúa constrói e anuncia uma diversidade enunciativa na qual "fronteiras" não significam somente o imaginário local, mas a forma de uma vagina dentada.

Segundo mitos sexuais fundadores analisados por Freud (1981), o falo masculino na Antiguidade representava a fecundidade da natureza e passou, depois, a ser conotado como o instrumento de perfuração, objeto do estupro e do poder do macho; o significante histórico da serpente que tentou Eva. A vagina, por outro lado, corporificou-se como aquela devoradora incansável do desejo masculino e a acolhedora do seu membro, a possuidora de dentes assustadores. Ao permitir que o macho a penetre, assinala a significação do poder feminino e 
o medo masculino, possibilitando a mudança do mito de Eva. A fêmea, então, pode guardar seus desejos assim como controlar a entrada do macho dentro de si. O ponto central desse pensamento, portanto, remete-nos a um ícone da guerra entre os sexos e parece que Anzaldúa apodera-se dessa "memória" quando analisa e salienta o fluxo da ferida aberta, comunicandonos a nova consciência, "the new mestiza". Essa reconstrução, de um modo geral, aparece no seguinte comentário tecido pela autora:

\begin{abstract}
Na América pré-Colombiana o símbolo mais notável era a serpente. Os Olmecs associavam a feminilidade à boca da Serpente que era guardada por uma fileira de perigosos dentes, um tipo de vagina dentada. Eles consideravam-na o lugar mais sagrado na terra, um lugar de refúgio, o ventre criativo do qual nasciam todas as coisas e para o qual todas as coisas retornavam. Pessoas serpentes possuíam furos, entradas para o corpo da Serpente Terra; eles seguiam o caminho da Serpente, identificados com a divindade Serpente, com a boca, o devorador e o devorado. O destino da humanidade é ser devorado pela Serpente. $\left(1999\right.$, p. 56) ${ }^{4}$
\end{abstract}

Trata-se, portanto, de percebermos que, neste ponto, Anzaldúa expressa suas novas reivindicações. "The New Mestiza" é marcada por conscientizar-se de seu passado histórico e por resistir, em sua espiritualidade, a adotar uma cultura que não tivesse as marcas de cidadania chicana. Primeiro, Anzaldúa recupera, por meio da escrita, seu passado précolombiano. Não lhe escapam possibilidades íntimas e sentimentais de divinizar o significado polissêmico do significante virgem. Depois, ao resgatar relatos oficiosos dos quais a aparição da Virgem de Guadalupe faz parte, Anzaldúa subverte dogmas e empreende ligações entre a Virgem católica e a deusa dos astecas Coatlicue. Ao construir um certo aspecto míticotradicional entre Guadalupe e Coatlicue, fortemente caracterizado desde a invasão colonial, o discurso político de Anzaldúa sobre a Virgem católica é instalado em uma subjetividade transfronteiriça que, além de retornar às discussões abordadas sobre raça, religião e línguas, recoloca estratégias discursivas às voltas com o gênero e a sexualidade. Anzaldúa comenta:

E há um componente onde parte de mim quer parar com isso, quer brecar, dizer que é muito doloroso, muito duro. A rebelde em mim coloca seus pés no chão. E eu associo isso a estados depressivos e bloqueios na minha escritura. Mas quando isso fica muito [...] rápido, alguém perde o chão para a realidade ou para algum aspecto de pertencimento, e fica-se perdido. E fica-se frustrado sendo muito 
desconfortável e é quando você quer parar e dizer: "Para que eu quero descer". Ou "Vou permanecer nessa situação específica, nessa casa específica, não quero me mexer, por enquanto. Quero descansar e me recuperar". E como conceito nepantla ${ }^{5}$ eu articulo a ideia de que o mundo está se movendo muito rápido e está muito confuso. $(2000, \mathrm{p}, 13-14)^{6}$

Dessa maneira, a política identitária da nova mestiça pode ser vista na paisagem conscientizada das questões sobre o gênero pela qual deve ser rearticulada a mulher chicana. Ao apropriar-se da imagem de Guadalupe, Anzaldúa fornece-nos o motivo de buscar na sua assexualidade, aquela "fronteira" na qual tanto as diferenças raciais quanto as sexuais marcaram um "local” de encontro. Para ela, é aqui, na "fronteira", que ela encontrou a ligação mais vantajosa entre suas pesquisas acadêmicas e a política do conhecimento. Também, de acordo com a autora,

Minha família, como a maioria dos chicanos, não pratica o catolicismo romano, mas um catolicismo nacional com muitos elementos pagãos. O nome indígena da Virgem de Guadalupe é Coatlalopeuh. Ela é a divindade central conectando-nos à nossa ancestralidade indígena. $\left(1999\right.$, p. 49) ${ }^{7}$

Neste ponto, resta-nos argumentar sobre novas ideias para a construção de identidades chicanas.

A primeira questão seria que os "grandes centros" urbanos, por exemplo, já dividem espaço, de modo nacional e internacional, com diferentes funcionalidades citadinas integradas entre si. Não há como dizermos que a população do mundo não se encontre "urbanizada", esteja ela na cidade ou no campo; parece não haver como fugirmos da ordem global do século XXI, cuja espacialidade é o principal objeto de conexões entre fronteiras. A produção de cada uma das fronteiras resulta nos links, espraiando significâncias de maneira que estendam misturas a qualquer outro "centro" não globalizado.

Dessa maneira, transpor fronteiras já teve seu início de forma acelerada e podemos perceber a influência que esta questão desperta entre o local e o global. As "fronteiras" passam a funcionar, para Anzaldúa, como o locus de múltiplos confrontos para se definir aquilo que poderia ser um "lugar seguro", ou "inseguro"; o distinguir-se entre o "nós" e o 
"eles". Uma ilimitada construção de imagens vem prover, daqui para a frente, um corpo que tanto pode significar um sujeito manifesto em enunciações, ou um sujeito universal, ou, até mesmo, a fragmentação de rostos e de almas, ou, inclusive, a substância imaterial de explicações não encontradas. Mais que qualquer substancialização preenchendo a falta deixada pelo vazio, importa percebermos que esse sujeito é construído e posicionado constantemente pela linguagem; subjetivado nas instâncias do discurso e, em consequência, constituído como fenômeno histórico.

Por meio dessas inter-relações, a autora aborda a noção de fronteira(s) como aquela de distinção e diferença, mas, também, de contaminação, semelhança e mistura. Isto é, ela percebe as fronteiras como a materialização de leis, uma vez que estas policiam as divisas colocadas pelo homem. De modo semelhante, as mesmas fronteiras vão sendo transformadas, vazadas, subvertidas. Uma vez usadas para controlar e exercer o poder sobre o outro, as fronteiras permitem, também, regular movimentos migratórios de rebeldia e de confronto. Sendo assim, ao mesmo tempo que promovem práticas interculturais levando à hibridização entre antigas homogeneidades, elas conotam, igualmente, a discórdia e a divergência que desencadeiam violentos atritos levando uns e outros à prática do ódio e da morte.

Ao marcarem essa busca, é como se as fronteiras prometessem uma noção de origem, de casa, de segurança, uma estabilidade, tanto quanto uma experiência sobre como enfrentar as diferenças para formar a identidade procurada. Falar em diferença, em desigualdade, tornase, portanto, a ressonância em que circulam complexidades de ações multidirecionais, resultando em literariedades culturais da voz chicana.

Dessa forma, ao identificarmos uma (re)construção de subjetividades expressas em identidades sujeitas à mudança, há o desenvolvimento de uma espécie de práxis expressiva em um tipo de crítica que costuma referencializar tanto o passado quanto o presente, o "eu" e o "outro", e, até mesmo, uma interioridade/exterioridade. O reflexo da profunda inovação 
reflete-se em narrativas entre antigas e novas argumentações. Os discursos transformam-se. Anzaldúa tece o seguinte comentário:

\footnotetext{
Minha identidade Chicana está solidificada na história da resistência da mulher indígena. Os ritos Astecas de luto feminino eram ritos de desafio contestando as mudanças culturais que interrompiam a igualdade e o equilíbrio entre o feminino e o masculino, e protestavam contra seu rebaixamento para um status inferior, sua degradação. Como La Llorona o único meio de protesto da mulher indígena era a lamentação.

Então mamãe, Raza, quão maravilhoso não ter de prestar contas a ninguém. Eu me sinto perfeitamente livre para rebelar-me e xingar minha cultura. $(1999, \text { p. } 43)^{8}$
}

Verificamos que a autora desestabiliza, com esta afirmação, a significativa rede do que sempre foi comunicado e estende suas posições em exemplos marcantes de novas especificidades discursivas agenciadas por ela mesma.

Além disso, como falante individual, Anzaldúa não fixa nenhum significado de maneira final e mostra-nos que a consciência mestiça implica a consciência da fronteira. Em sua prática autobiográfica, a fronteira é uma analogia identificada que poderíamos estabelecer entre o processo narrativo assumido por ela e o psicótico. Ambos têm dificuldades para associarem as partes como um todo a fim de assumirem uma representação mediante o conhecimento de unir as diversas partes visualizadas. Enquanto o psicótico demonstra um complexo interesse em identificar e reconhecer as partes de seu próprio corpo, Anzaldúa toma partes de "mundos" representados e tenta atualizá-los em uma multiplicidade de detalhes. Assim como escreve sobre Aztlán (a Terra natal), o outro México, o desterro, a terra perdida, o cruzamento ilegal da fronteira etc, ela também aborda os movimentos de rebeldia, dos símbolos fálicos, da herança de Coatlicue, como domar línguas ferinas, do estado xamânico, da consciência de ser mestiça, do Outro, de si mesma, do lesbianismo, da luta feminista.

Ao relatar essa ilimitada renúncia de ser vencida por um outro recurso que não seja o de expor-se bravamente pela palavra, ela deixa claro que age assim para contar a história da reorganização do seu povo, cuja dizimação pelo colonizador espanhol pesa como a mais sangrenta das feridas abertas no corpo. 
Partidária de uma estrutura própria - uma possibilidade independente de iniciativa e percepção; um aparente sentimento de se estar integrado com as mais profundas ambições e ideais, além de experienciar com o corpo e com a mente uma unidade significativa no espaço e no continuum do tempo - Anzaldúa visualiza alternativas de salvar-se pela escrita e migra para o Norte, tentando conquistar pelas letras, os adeptos que a ajudarão a definir suas tomadas de posição. Ela não deseja ser como as outras mulheres e casar-se, ou ser freira, ou ir para as ruas como prostituta. Ela optou por ser um sujeito da literatura cuja produção leva no bojo a escrita do alfabetizado e a oralidade de sociedades que se estabilizam por ensinamentos que dispensam a cultura branca do letramento. Isto é, enquanto o poder da escrita leva-nos a supor porque os homens sentem-se tão poderosos quando detêm sua posse, Anzaldúa lança mão de saberes orais que seu povo sempre defendeu, para estruturá-los em uma forma narrativa que mostra o caminho da continuidade de sentido.

Ao escolher esse caminho, ela determinou ser única, sem ser o avesso de ninguém. E aí fica incluído, o fato de ela jamais conseguir casar-se com um homem porque não seria o avesso do macho, mas, exatamente, o diferente, o Outro. Este olhar é lançado com o seguinte comentário:

\begin{abstract}
A cultura espera que as mulheres demonstrem maior aceitação e compromisso com o sistema de valores do que os homens [...] Se uma mulher permanece virgem até casar-se, ela é uma boa mulher [...] As mulheres são feitas para sentirem-se completas fracassadas se elas não se casarem e não tiverem filhos. "E quando te casas Gloria? O trem vai passar". E eu respondo-lhes: "Se eu me casar não há de ser com um homem". Ficam caladinhas. Sim, sou filha da Chingada. Sempre fui sua filha. Não fiquem me atrapalhando. $(1999, \text { p. } 39)^{9}$
\end{abstract}

Por meio desses diversos elementos, identificamos a personagem principal da autora como sendo a própria narrativa. O relato será o objeto a lidar com nossa atenção, uma vez que os muitos temas abordados por Anzaldúa dão margem para que interessemo-nos por eles e fiquemos centrados nessa voz poderosa que nos atém na busca de efeitos de sentido. 
Percebemos assim que, ao invés de uma única estética literária, existem, em sua obra,

tantas delas quantas nossa discursivização for capaz de legitimar.

\section{NOTAS}

1- "with Borderlands, what surprise me the most was that the metaphor of the borderlands speaks to its time much more than I thought it would. So that it's being taken up by a lot of different people who are in different disciplines, who are in different countries. And even from Japan I got a call, these people who wanted me to expound on this metaphor". (ANZALDÚA, in REUMAN, A. E. Coming Into Play: An Interview with Gloria Anzaldúa. MELUS, v. 25, n. 2, p. 5, summer 2000)

2- "What I'm trying to articulate now is kind of a mestizaje, a nos/otras, the nos is us/we/me/the subject; the otras is them/they/the object, and in nos/otras we are them and they are us and we're contaminated by each other. It's hard; it's like a tight-rope that if I allow the Eurocentriic part of me too much space it means that I have turned back on my race, the Chicanos and Mexicanos. If I stick too much to this nationalism, then it means I'm not realistic, I'm not being in the late twentieth century, living with these realities because for me it's not enough to be a Chicana because I'm also a dyke, I am also a writer, I'm a scholar, I have been in school, in white schools all my life, so those are parts of me. And yes, in negotiating the two different nationalities I've come up with this thing that I call the new tribalism. I am attempting to not react to either one of these sides, but to act, to be proactive rather than reactive, and that's really hard to do, 'cause there are no maps. And a lot of times there are no words, and - or if there are words they are implicated in a binary system of English or of Spanish, and especially Spanish where the language is gender-fixed". (ibid, p. 11)

3- "The other mode of consciousness facilitates images from the soul and the unconscious through dreams and the imagination. Its work is labeled "fiction", make-believe, wish-fulfillment. White anthropologistis claim that Indians have "primitive" and therefore deficient minds, that we cannot think in the higher mode of consciousness - rationality. They are fascinated by what they call the "magical" mind, the "savage" mind, the participation mystique of the mind that says the world of the imagination - the world of the soul - and of the spirit is just as real as physical reality". (ANZALDÚA, 1999, p. 59)

4- "In pre-Columbian America the most notable symbol was the serpent. The Olmecs associated womanhood with the Serpent's mouth wich was guarded by rows of dangerous teeth, a sort of vagina dentada. They considered it the most sacred place on earth, a place of refuge, the creative womb from which all things were born and to which all things returned. Snake people had holes, entrances to the body of the Earth Serpent; they followed the Serpent's way, identified with the serpent deity, with the mouth, both the eater and the eaten. The destiny of humankind is to be devoured by the Serpent". (ANZALDÚA, 1999, p. 56)

5- Segundo Anzaldúa, neplanta "é basicamente aquela habilidade de viajar através de mundos, de pular de um lugar para outro ou de uma identidade particular para outra, e assim, algumas das histórias lidam com esse estado neplanta que têm diferentes estágios, em que Coatlicue é somente um [...] E em neplanta há outros lugares que eu não articulei em Borderlands mas aqueles nas Lloronas" - ["it's basically that ability to travel through worlds, to jump from one locale to the other or one particular identity to the other, and so some of the stories deal with this nplanta state which has different stages, of which the Coatlicue is onky one [...] And in neplanta there are other stations that I did not articulate in Borderlands but that in Lloronas"]. (ANZALDÚA, in REUMAN, A. E. Coming Into Play: An Interview with Gloria Anzaldúa. MELUS, v. 25, n. 2, p. 13, summer 2000)

6- "And there's a component where part of me wants to stop it, wants to put the brakes on, wants to say it's too painful, too hard. The rebel in me puts its foot down. And I associate that with depressive states and blocks in my writing. But when it gets too [...] fast, one loses one's grounding to reality or to some 
aspect of belonging, and one gets lost. And gets frustrated and it's very uncomfortable and that's when you want to put your foot down and say, "Let me train stop, I want to get off". Or "I'm going to stay in this particular situation, this particular house, I don't want to move on for a while. I want to rest up and recuperate." And in the nepantla concept I articulate this idea that the world is moving too fast and it's too confusing". (ANZALDÚA, in REUMAN, A. E. Coming Into Play: An Interview with Gloria Anzaldúa. Melus, v. 25, n. 2, p.13-14, Summer 2000)

7- "My family, like most Chicanos, did not practice Roman Catlolicism but folk Catholicism with many pagan elements. La Virgem de Guadalupe's Indian name is Coatlalopeub. She is the central deity connecting us to our Indian ancestry". (ANZALDÚA, 1999, p. 49)

8- "My Chicana identity is grounded in the Indian woman's history of resistence. The Aztec female rites of mourning were rites of defiance protesting the cultural changes which disrupted the equality and balance between female and male, and protesting their demotion to a lesser status, their denigration. Like La Llorona, the Indian woman's only means of protest was wailing.

So mamá, Raza, how wonderful, no tener que rendir cuentas a nadie. I feel perfectly free to rebel and to rail against my culture". (ANZALDÚA, 1999, p. 43)

9- "The culture expects women to show greater acceptance of, and commitment to, the value system than men [...] If a woman remains a virgen until she marries, she is a good woman [...] Women are made to feel total failures if they don't marry and have children. "Y cuándo te casas, Gloria? Se te va a pasar el tren." Y yo les digo, "Pos si me caso, na va ser con un hombre." Se quedan calladitas. Sí, soy hija de la Chingada, I've always been her daughter. No 'tés chingando”. (ANZALDÚA, 1999, p. 39) 


\section{GLORIA EVANGELINA ANZALDÚA}

Gloria Evangelina Anzaldúa nasceu no Vale do Rio Grande, ao Sul do Texas, Estados Unidos, no dia 26 de setembro de 1942, filha de Urbano e Amália Anzaldúa. Faleceu no dia 16 de maio de 2004, já internacionalmente conhecida como escritora e teórica cultural, devido a complicações relacionadas ao diabetes. Apesar de sempre ter sido vítima de racismo e outras formas de opressão, ela foi bem sucedida em sua carreira acadêmica, obtendo seu B.A na universidade Pan American, e seu M.A na Universidade do Texas, em Austin.

Anzaldúa publicou poesia, ensaios teóricos, contos, narrativas autobiográficas, entrevistas, livros infantis e antologias de vários gêneros, desempenhando um papel de relevância política nas estratégias de redefinição das identidades chicanas, lésbicas e queer. A autora foi, ainda, editora e coeditora de três antologias multiculturais.

Além de Borderlands / La Frontera: The New Mestiza (San Francisco: Aunt Lute Books, 1987), Anzaldúa publicou, também, as seguintes obras:

\section{LIVROS:}

Interviews / Entrevistas, com AnaLouise Keating (2000); La Prieta (1997); Prietita and the Ghost Woman / Prietita y La Llorona (1996); Friends from the Other Side / Amigos del otro lado (1993); Prietita has a friend / Prietita tiene un Amigo (1991).

\section{OUTRAS PUBLICAÇÕES:}

Lloronas, Women Who Houd: Autohistorias - Teorias and the production of Writing, Knowledge, and Identity, 1996; com Moraga, Cherrie, eds. This Bridge called My Back: Writings by Radical Women of Color. Massachussets: Persephone Press, 1981; Making Face, Making Soul/Haciendo Caras: Creative and Critical Perspectives by Women of Color. San Francisco: Aunt Lute, 1990; Cassell's Encyclopedia of Queer Myth, Symbol and Spirit: Gay, Lesbian, Bisexual and Transgender Lore. London, Herdon, VA: Cassell Academic, 1998.

Anzaldúa recebeu inúmeros prêmios, inclusive o prêmio American Book da Fundação Before Columbus, o Lamda Lesbian Small Book Press, o Prêmio de Ficção NEA (National Endowment for the Arts), o Lesbian Rights, o Sappho com Distinção, e o prêmio Lifetime Achievement da Associação de Estudos Americanos. 


\section{CAPÍTULO II}

\section{4- Conhecendo "Borderlands" - o território da tradução expresso na voz de Anzaldúa}

Anzaldúa oferece-nos uma obra dividida em sete capítulos iniciais, todos eles escritos em prosa para, em seguida, fazer uma reflexão escrita em versos, dividida em seis capítulos.

Essa construção adverte-nos que o trabalho da autora propõe-se a mostrar a fecundidade de suas incertezas e resistência política refletidas no espelho histórico da cultura chicana. Como resultado, suas numerosas propostas a respeito da criação de suas personagens, representam um efeito de realidade que estabelece estratégias histórico-literárias, ou seja, sua narrativa estabelece um hibridismo linguístico e um discurso social a respeito de identidades individuais e coletivas entrelaçadas interculturalmente entre o México e os Estados Unidos.

O primeiro capítulo, The Homeland, Aztlán El otro México (p. 23 a 35), mostra-nos o resgate e a reordenação do objetivo de vida de um povo depois de se perceber vivendo na fronteira entre dois países, realizando suas interferências para opinar sobre as contradições de um sistema legitimado como hegemônico, caso da fronteira México-Estados Unidos; mostranos como é sentir-se mal entendido, pois não se pertence nem a um nem a outro país; como é crescer na interface do desconforto do opressor; como é questionar-se para se impor como identidade.

Esta é a "herida abierta" que Anzaldúa postula como a necessidade e o desejo de se resgatar a terra perdida, aquela que promoveu uma instância crítica quando minou a hierarquia asteca, a continuidade imaginada do dia-a-dia de uma grande nação vivendo nas fronteiras. Segundo ela, os "Gringos no Sudoeste dos Estados Unidos consideram os habitantes das fronteiras transgressores, alienígenas - possuam eles documentos ou não, sejam 
eles chicanos, indígenas ou pretos" ["Gringos in the U.S. Southwest consider the inhabitants of the borderlands transgressors, aliens - whether they possess documents or not, whether they're Chicanos, Indians or Blacks".] (p. 25).

A aparente realidade na qual os mexicanos têm vivido marca o desespero de terem visto seus ranchos tomados pelos Estados Unidos, suas terras invadidas e anexadas pelos americanos, além de presenciarem quando levavam seus parentes e os deportavam. Mais uma vez, "a terra perdida" é elemento para significações literárias, psicológicas ou filosóficas, quando não, motivo para que a autora continue demonstrando o local, por excelência, de sua ação: “A tensão agarra-se aos habitantes da fronteira como um vírus. A ambivalência e o desassossego residem aí, e a morte não é nenhum forasteiro" comenta ela às voltas com sua dor ["Tension grips the inhabitants of the borderlands like a vírus. Ambivalence and unrest reside there and death is no stranger".] (p. 26).

Parece não haver qualquer descanso para os chicanos. Quando não estão se escondendo da migra, estão relegados às margens. Eles não conseguem encontrar o caminho que torne possível seu surgimento como povo, pois Anzaldúa também nos conta que desde o início do século XVI “os espanhóis e Hernán Cortés invadiram o México e, com a ajuda de tribos que os astecas tinham subjugado, conquistaram-no" ["the Spaniards and Hernán Cortés invaded México and, with the help of tribes that the Astecs had subjugated, conquered it”.] (p. 27). Desde então, as estratégias políticas particularmente usadas pelos chicanos para situarem sua nova autoridade, têm ficado aquém da criação e da ampliação do seu poder de conhecimento para ajudarem em suas repercussões. E a autora acrescenta: "Imediatamente após a Conquista, a população indígena foi reduzida para menos de sete milhões de pessoas. Por volta de 1650, apenas um milhão e meio de índios com sangue indígena sobreviveu." ["Immediately after the Conquest, the Indian population had been reduced to under seven million. By 1650, only one-and-a-half-million pure-blooded Indians remained".] (p. 27). Com 
essas afirmações, percebemos que os "limites", para os chicanos, são rígidos, muito bem demarcados, difíceis de serem transpostos.

Ela narra, também, que nos anos de 1800 (desde o início do século XIX), os anglos "cometiam todo tipo de atrocidades contra eles" ["committing all manner of atrocities against them".] (p. 28). Em 1846, o México é chamado para a guerra pelos Estados Unidos, e o México perde território.

Repovoando suas formas realistas/literárias, Anzaldúa materializa essa opressão em testemunhos por meio dos quais documenta a esfera superior do poder do Outro e seu desassossego em relação à formação da sua cultura. Sublinhando a condição de ser a mais velha de nove irmãos, ela se torna a ouvinte das histórias que sua avó e sua mãe contavam. Ouve a voz da mãe dizer sobre a aridez da terra, a morte dos animais que não resistiam à seca, ouve sobre a morte do pai e como a mãe perdeu as terras. Ela, a mãe, não conseguia se fazer entender por não falar inglês.

Para conseguir chamar a atenção de todos e sair em defesa da comunidade chicana, Anzaldúa dimensiona o seguinte: "Com a vitória das forças dos Estados Unidos na Guerra México-Estados Unidos, os americanos tiraram 100 milhas das nossas fronteiras texanas, desde $o$ rio Nueces até $o$ rio Grande" ["With the victory of the U.S. forces over the Mexican in the U.S.-Mexican War, los norteamericanos pushed the Texas border down 100 miles, from el río Nueces to el río Grande"] (p. 29).

A principal questão, assim, transparece como a contemporânea agonia em tirar dos chicanos aquilo que é considerado como seu, de eles não poderem conhecer o envolvimento com suas verdadeiras terras, de não resgatarem os valores perdidos. A "verdade" sobre as investigações se desconstrói por meio da fala hegemônica do outro, os Estados Unidos. Exceto por meio de convenções aparentemente transparentes, os Estados Unidos têm afirmado que compraram essas terras dos chicanos. Entretanto, Anzaldúa contesta. Ela nos 
diz: "Minha pobre mãe, viúva, perdeu dois terços de seu gado. Um advogado espertalhão tirou-lhe a terra porque mamãe não tinha pago os impostos" ["Mi pobre madre viuda perdió two-thirds of her ganado. A smart gabacho lawyer took the land away mamá hadn't paid taxes".] (p. 30).

Tudo parece traduzir o sofrimento dessa gente em se firmar como autenticidade que reclama seu lugar. Não há como não identificarmos a opressão a que os chicanos se veem submetidos. E Anzaldúa acrescenta: “Nos anos 30, depois das corporações dos agro negócios ingleses trapacearem os pequenos proprietários chicanos, essas corporações contrataram gangues de mexicanos para que aqueles caíssem fora dali, para expulsar o povo, para irrigar o deserto" ["In the 1930s, after Anglo agribusines corporations cheated the small Chicano landowners of their land, the corporations hired gangs of mexicanos to pull out the brush, chaparral and cactus and to irrigate the desert”.] (p. 31). As pretensões chicanas, portanto, deviam mudar, tomar outro rumo.

Em contato com tantos desastres, era o momento de ultrapassarem os limites, pois, "para muitos mexicanos do outro lado, a escolha era ficar no México e passar fome ou mudarse para o norte e viver" ["for many mexicanos del otro lado, the choice is to stay in México and starve or move north and live".] (p. 32). Aliás, nessa constituição de autodenominar-se chicano/a e participar da evolução histórica, ressoa a frase "Em cada chicano e mexicano vive o mito do tesouro territorial perdido. Os Norte-Americanos chamam esse retorno à casa de invasão silenciosa" ["En cada Chicano y mexicano vive el mito del tesoro territorial perdido. North Americans call this return to the homeland the silent invasion".] (p.32).

Daí não mais existir volta para os chicanos se manterem alheios, indiferentes às suas causas. A imigração mexicana para os Estados Unidos tem acontecido há três séculos, e a linguagem de todo chicano concretiza-se na fala reivindicatória da terra usurpada. Como em 
qualquer outra manifestação de perda, surgem os procedimentos de se definirem as lutas para se alcançar o objetivo de retomada daquilo que consideram seu, e tentar transformações.

Surge, assim, "um terceiro país, um país fechado" ["a third country, a closed country"], onde os "mojados" são vistos como aqueles que preocupados em encaminharem-se para o outro lado, o norte, são novamente encarados como invasores e muitos são mandados de volta ao México (p. 33).

Anzaldúa se reporta ao fato da seguinte maneira:

\begin{abstract}
Hoje, milhares de mexicanos estão cruzando a fronteira legal e ilegalmente; dez milhões de pessoas sem documentos retornaram para o sudoeste.

Descaracterizados, sem nome, invisíveis, escarnecidos com um "Olá, cucaracho" (barata). Tremendo de medo, mas cheios de coragem, uma coragem nascida do desespero. Descalços e sem educação formal, os mexicanos, com as mãos como solas de sapato reúnem-se à noite na margem do rio onde dois mundos emergem criando o que Reagan chama de front, uma zona de guerra. A convergência tem criado uma cultura de choque, uma cultura de fronteira, um terceiro país, um país fechado. (1999, p. $33)^{1}$
\end{abstract}

Neste ponto, Anzaldúa procura mostrar-nos outras "verdades" compondo o drama do destino chicano. A autora conta que a mulher encontra-se em situação especial de risco. Ou ela é estuprada, ou vendida para prostituição pelo coyote; o contrabandista não a alimenta por dias a fio e não permite sequer que use o banheiro. A jornada de trabalho desumano que a mulher enfrenta, submetendo-se a uma clara asfixia social a faz ficar "enferma dos nervos, de pressão alta" ["Se enferma de los nervios, de alta presión"] e, consequentemente, traduzem a coexistência dos aproveitadores sugando-lhes a totalidade de suas capacidades físicas e mentais (p. 34).

A mulher "indocumentada" passa a caracterizar as graves e até mesmo mortais situações para suprir as próprias necessidades. Representantes de pretextos para exploração, essas refugiadas encarnam a dança do grotesco vampirismo movimentando-se naquele país cujo poder, segundo Anzaldúa, exerce a tirania sobre os chicanos. Ela tece o seguinte comentário: 
A molhada, a mulher indocumentada, é duplamente ameaçada neste país. Ela não tem de lutar somente contra a violência sexual, mas como todas as mulheres, ela está presa a um sentimento de desamparo físico. Como uma refugiada, ela deixa a segurança e o conforto do lar para se aventurar em um terreno desconhecido e possivelmente perigoso.

\section{Este é seu lar}

Esta delgada borda de

Arame farpado. (1999, p. 34-35) ${ }^{2}$

Com essas afirmações, fica registrada a ameaça que todos, homens e mulheres chicanos sofrem cotidianamente. O risco de serem vistos como algo negativo, que atrapalha a economia, a cultura e a história dos Estados Unidos, conta como ponto para que eles sejam discriminados dentro desta sociedade. Ou os chicanos se adaptam às leis da hegemonia estadunidense, ou, então, são considerados outsiders, indivíduos de natureza sem ideologia, pessoas formando uma sociedade desorganizada, indivíduos incapazes, representantes de uma subjetividade em desarmonia com as ordens vigentes.

No capítulo “Movimientos de rebeldía y las culturas que traicionan” (p. 37 a 45), encontramos Anzaldúa narrando uma série de representações tais como ser indiferente a muitos valores de sua própria cultura, o de não ser obediente a determinadas regras, a de ser rebelde por natureza, a de levar em conta os próprios desejos de contar com o resgate de suas dimensões sufocadas.

Com isso, as propostas da autora em refletir sobre o mundo remetem a um estado de permanente (re)interpretações, afirmando que "Cultura forma nossas crenças" ["Culture forms our beliefs"] (p. 38). Ela reconhece que novos modelos para se formar a identidade de um povo estão conectados à situação mundial, principalmente pelo fato de o domínio de uma cultura estar ligado à hegemonia econômica, portanto, com poder de influenciar a composição de várias culturas e identidades.

Anzaldúa, então, expõe seus interesses em crescer como intelectual para se firmar como Raza, utilizando a mistura cultural para apresentar novas ideias. 
Ela narra, também, como se deu o fato de ser a primeira de seis gerações que deixou o vale onde sempre morou com a família, para ir estudar e utilizar-se da política cultural para promover a ideologia chicana. E quando lhe perguntam se ela gosta de ser assim como é, ela se percebe para além da tradição e mostra-nos que sempre esteve inscrita no cenário das contestações. Ela reconhece que sua rebeldia tem lhe custado muito caro. Por diversas vezes, ela se sente "inútil, estúpida, e impotente" ["sentiéndome inútil, estúpida, e impotente."] (p. $37)$.

Percebemos, desse modo, que, por essa opção, ela encarna combinações político/sociais que a levarão a comprometer-se com uma vida literária voltada para as objetividades do trabalho humano, principalmente ao representar, pela escrita, o discurso chicano. Com isso, Anzaldúa sugere a coexistência de duas linguagens, a artística e a da tradição, e comenta que a mulher tinha três caminhos a seguir: ir para a Igreja e converter-se em freira, ir para as ruas como prostituta, ou ficar em casa e tornar-se mãe (p. 39).

Anzaldúa não se submete a nenhuma hierarquia pré-existente, pois a extensão desse seu âmbito privado parece ter a intenção de fornecer os pressupostos básicos de seu funcionamento de rebeldia. O objetivo dela é justamente criticar as injustiças sociais das quais é vítima, rearticular sua fala em consonância com interesses de rivalidade cultural estrangeira, e afirmar, então, o seguinte: "Hoje, algumas de nós tem uma quarta opção: entrar no mundo pelas vias da educação e da carreira e tornar-se pessoas autônomas" ["Today some of us have a fourth choice: entering the world by way of education and career and becoming selfautonomous persons".] (p. 39). Porém, ela enfatiza que são algumas que têm essa possibilidade, havendo ainda um longo caminho a ser percorrido pelas mulheres.

Como vemos, sua conduta, em especial no tocante à sua não subordinação, mas em colaboração com exigências, fornece resultados previsíveis quanto ao fato de seus conflitos internos serem amenizados pela desobediência. 
$\mathrm{Na}$ verdade, essa sua luta por direitos individuais estabelece um paradigma que permite a constituição de sua identidade como a plataforma que desautoriza determinadas circunstâncias sociais dos chicanos em função de sua resistência. Segundo ela, "muito do que a cultura condena está focado sobre as afinidades familiares. O bem-estar da família, da comunidade e da tribo, é mais importante do que o bem-estar individual. O indivíduo existe primeiro, como família - irmã, pai, padrinho - por último, como ele mesmo" ["Much of what the culture condemns focuses on kinship relationships. The welfare of the family, the community, and the tribe is more important than the welfare of the individual. The individual exists first as kin - as sister, as father, as padrino - and last as self'.] (p. 40).

Por essa hipótese, ela reconstrói sua retórica, continua deslocando pensamentos e acrescenta que é aquela meio-a-meio, duas em uma só, macho e fêmea (p.41). Neste sentido, distancia-se de uma gama de efeitos que a inserem em situações-limite e acrescenta que “Alienada de sua cultura mãe, 'alienígena' na cultura dominante, a mulher de cor não se sente segura no mais fundo de seu próprio Self" ["Alienated from her mother culture, "alien” in the dominant culture, the woman of color does not feel safe within the inner life of her Self".] (p. 42).

Vemos estampadas aí, formulações extraídas de sua valorização ficcional. Ao mesmo tempo que Anzaldúa ficcionaliza suas histórias, estas servem-lhe de espelho para refletirem o óbvio, a não existência de uma linha divisória nítida entre os textos de suas histórias e a literatura. Sendo assim, Anzaldúa se sente livre para recorrer às duas sempre que isto lhe for conveniente.

Ela é uma mulher cujo herói literário parece ser ela própria, recorrendo a todo testemunho que lhe condiz quando se trata de falar sobre a importância de ser chicana, engajada em projetos desenvolvimentistas, promovendo um efeito de "realidade" que vemos expresso nas seguintes palavras: "De minha parte, eu não temo qualquer traição porque, 
diferente das chicanas e de outras mulheres de cor que cresceram brancas ou que apenas recentemente retornaram às suas raízes culturais nativas, eu estive totalmente imersa na minha" ["I fear no betrayal on my part because, unlike Chicanas and other women of color who grew up white or who have only recently returned to their native cultural roots, I was totally immersed in mine"] (p. 43).

O ponto aqui, como vemos, é ressaltar sua essência como mulher a quem foi destinado o signo de desconstruir a hegemonia dos sistemas de controle e opressão estrangeiros encontrados nas fronteiras culturais para, então, reciclar esses feitos em favor da população. De acordo com Yúdice,

\footnotetext{
Realmente, quando a "cultura" acontece na fronteira, os efeitos do evento agravam as desigualdades da região, especialmente se o capital cultural resultante aumenta o de quem já o tem de sobra: os patrocinadores, os diretores, os curadores, os artistas e os públicos que habitualmente comparecem a eventos artísticos. Uma vez que o capital cultural se traduz em termos de valor estético, social, político e até comercial, existe, portanto, um "retorno" do investimento de capital e de trabalho. Mas qual é o "retorno" para a população local? (2004, p. 402)
}

Dessa maneira, Anzaldúa “conscientizou-se” de que, oposta à administração colonial, a sua vontade de construir uma outra nação cuja arbitrariedade econômica, linguística e religiosa ou cultural tem despontado livremente, é o início de um outro horizonte de libertação para os chicanos. Segundo ela, "O pior tipo de traição está em fazer-nos acreditar que a mulher indígena em nós é a traidora” ["The worst kind of betrayal lies in making us believe that the Indian woman in us is the betrayer".] (p. 44).

Suas formulações, portanto, se expressam nos movimentos de sua libertação e de sua "descolonização" do poder do outro. Ainda segundo ela, "São os costumes que traem. A indígena em mim é a sombra: La Chingada, Tlazolteotl, Coatlicue. São elas que ouvimos lamentando suas filhas perdidas" [“Son los costumbres que traicionan. La índia em mi es la sombra: La Chingada, Tlazolteotl, Coatlicue. Son ellas que oyemos lamentando a sus hijas perdidas.] (p. 44). 
Assim, mundo empírico e literatura para Anzaldúa não estarão mais separados, mas conjugados para o seu itinerário de representatividades, um movimento irresistível, que nos leva a visualizar sua estratégia na criação de espetáculos de "realidades". Abstrata e ao mesmo tempo vinculada à tradição, ela manifesta sua incessante transformação no que diz respeito às reflexões sobre si mesma e a respeito de sua cultura. Mais uma vez, ela mostra que sabe criticar e descrever as essências da vida cotidiana.

Podemos depreender, ao lermos o terceiro capítulo de Boderlands, "Entering Into the Serpent" (p. 47 a 61), que a literatura é um "lugar" particularmente apropriado para que Anzaldúa mostre a multiplicidade de "mundos" emergentes em suas narrativas. Como uma tensão documentando a vida que se revolve como "verdades" a serem ditas, a autora se recusa a permanecer calada e se coloca livre para falar sobre alguns mitos de seu povo que personificam a fé chicana.

Aludindo essas imagens, Anzaldúa explora esses mitos e manipula nossa imaginação para preencher, em sua escrita, as fendas dessas representações para serem ocupadas por perspectivas que nos façam visualizar o desejo da mulher de fronteira, sua mudança de consciência. Ela comenta que, para "impedir as cobras sob a varanda", ela teria de "voltar para dentro da cozinha, pisar em uma delas, enorme, deslizando pelo chão" ["Avoiding the snakes under the porch I walk back into the kitchen, step on a big one slithering across the floor”.] (p. 47).

Como uma linha contínua, vemos que nessa imagem, algo da memória do povo e dela própria se desmanchou através dos tempos e uma outra memória teve lugar, por meio da lembrança, para realizar a construção de um outro momento político passando de um sistema de signos para outro. O que Anzaldúa ganha com esse poder descritivo de intervenção são as vantagens de ela se estruturar como voz emergente para fundamentar o todo social chicano, 
incluindo, aí, a intenção de dizer as "verdades" sobre seu povo. Ela tem uma linguagem dominadora e nos "fala" como instrumento de interpretação do mundo.

Fica patente a dificuldade de Anzaldúa romper com a tradição. Acreditamos ser essa dificuldade o foco para mostrar suas atividades em oferecer-nos a essência da "mulher" de ideias retratando seus mitos. Ela resolve falar sobre as mães mitológicas dos chicanos e a primeira delas a ser mencionada é Coatlalopeuh, descrita como a deusa da Terra, a que encarna a fertilidade Mesoamericana. Ela é a "divindade central" conectando-os à sua ancestralidade indígena (p. 49).

Desejamos argumentar que, para Anzaldúa, é relevante defender seu pensamento sobre os mitos de seu povo de maneira que essas questões se atualizem na vida diária dos chicanos, pois esses novos significados e novos valores podem enunciar uma nova ordem social.

Dessa maneira, a mãe Coatlicue é a evocada como a imagem da dualidade que "deu ao México o cacto, planta que provê ao povo o leite e o pulque" e a que "defende seus filhos contra a fúria do Deus Cristão" ["It was she who gave México the cactus plant to provide her people with milk and pulque. It was she who defended her children against the wrath of the Christian God".] (p. 49).

Neste ponto, poderíamos prever que essa mãe consiste em fundamentar o teatro da heróica força de viver, ou seja, as histórias narradas sobre ela deixam-nos perceber a vontade inquestionável de gozar a vida conscientemente, pois Coatlicue passa a ser considerada a vigorosa força criadora da vida, a ilusão entre o "ter" da colheita, e o "provimento" dos elementos para construir uma cultura de riquezas. Ela encarna a necessidade de compensar a memória histórica da "falta" com um valor sobre aquilo que singulariza a essência do objeto fornecido. Mais do que qualquer coisa, a função dessa mãe é fornecer o mais amplo funcionamento para aproximar os diferentes elementos de uma mesma comunidade. Para atingir essa mudança de consciência, Anzaldúa marca seu interesse pelas causas "marginais" e 
afilia-se ao social por meio de seus projetos intelectuais, por meio de estudos sobre sua cultura, originando novas possibilidades de abordagens do passado.

Constantemente confrontada com essas reflexões, Anzaldúa alega que "Depois da Conquista, os espanhóis e suas igrejas continuaram separando Tonantsi/Guadalupe. Eles dessexualizaram Guadalupe tirando Coatlalopeuh, a serpente/sexualidade, fora dela" ["After the Conquest, the Spaniards and their Church continued to split Tonantsi/Guadalupe. They desexed Guadalupe taking Coatlalopeub, the serpent/sexuality, out of her".] (p. 49).

Dessa maneira, a segunda das mães é Guadalupe, a que possibilita e funde a fé; a mãe pura que protege o povo mexicano. Piedosa e isenta de críticas, Guadalupe carrega a substância e o vigor de viver fora dos domínios espanhóis, pois "Desde então para o mexicano, ser Guadalupano é algo essencial/desde então para o mexicano ser Guadalupano é algo essencial" ["Desde entonces para el mexicano ser Guadalupano es algo esenciall since then for the Mexican, to be a Guadalupano is something essential".] (p. 51).

Como vemos, essas mães estruturam os sentimentos de Anzaldúa para designar a inter-relação entre a tradição e as maneiras tangíveis que marcam suas atitudes. Ser guadalupano é seguir uma produção crítica para enfrentar a pressão dos tempos. Ainda de acordo com Anzaldúa, referindo-se a Guadalupe:

\footnotetext{
Em 1660, a Igreja Católica Romana nomeou-a Mãe de Deus, considerando-a um sinônimo da Virgem Maria; ela se tornou a Santa Padroeira dos mexicanos. A tarefa de defender (ou ser patrono) tem sido atribuída, tradicionalmente, a deuses masculinos. Durante a Revolução Mexicana, Emiliano Zapata e Miguel Hidalgo usaram sua imagem para conduzir o povo mexicano à liberdade. Durante a greve da uva de 1965 em Delano, Califórnia, e nas subsequentes marchas dos fazendeiros chicanos no Texas e outras partes do sudoeste, sua imagem nas faixas foi manchete e uniu os fazendeiros. Pachucos (os que se vestem bem com terno de ombreiras e ternos largos) tatuaram sua imagem em seus corpos. Hoje, no Texas e no México, ela é mais venerada que Jesus ou Deus, o Pai. $(1999, \text { p. 51 })^{4}$
}

Assim, Guadalupe permite a aventura de verificar que "ela, como minha raça, é uma síntese do velho e do novo mundo, da religião e da cultura das duas raças em nossa psique, o conquistador e o conquistado, a reestruturação política e os argumentos éticos a serem 
seguidos" ["She, like my race, is a synthesis of the old world and the new, of the religion and culture of the two races in our psyche, the conquerors and the conquered".] (p. 52). Essa mãe é descoberta, portanto, como a personagem estimulante que habilita os chicanos em sua resistência de não aceitação do estrangeiro; a que exige disponibilidade para a troca, ao mesmo tempo que luta para a emergência da Raza chicana. Dessa forma, ela escapa aos demais modelos de produção de fé e aparece como exemplo de transformações: "Para os mexicanos de ambos os lados da fronteira, Guadalupe é o símbolo de nossa rebeldia contra o rico, a classe mais alta e a média; contra o subjugo do pobre e do indígena", comenta também a autora. ["To Mexicans on both sides of the border, Guadalupe is the symbol of our rebellion against the rich, upper and middleclass; against subjugation of the poor and the indio"] (p. 52).

Uma outra configuração dessas memórias parece estar inscrita em seu discurso, descrevendo as transformações pelas quais passaram as comunidades chicanas. Os "mestizos" choram até hoje a divisão instalada na etnia permitindo que sua condição social fosse atravessada por todo e qualquer pensamento estrangeiro, pois, segundo ela, "O povo adorava o Senhor e a Senhora da Dualidade, Ometecuhtli e Omecihuatl. Antes da dominação masculina, Coatlicue, a Senhora da Pele de Serpente, detinha o equilíbrio entre as dualidades macho e fêmea, luz e sombra, vida e morte" ["The people worshipped the Lord and Lady of Duality, Ometecuhtli and Omecihuatl. Before the change to male dominance, Coatlicue, Lady of the Serpent Skirt, contained and balanced the dualities of male and female, light and dark, life and death".] (p. 53-54).

Como podemos depreender, a veemência com que esses fatos são registrados por Anzaldúa é fruto de uma produção acadêmica, cujas associações são trabalhadas em solidariedade e cooperação com o pensamento chicano. A correspondência entre as virgens 
Coatlicue, Tonantsi, Guadalupe, fica simultaneamente inserida em seu discurso, levando a autora a considerar suas outras mães mitológicas.

Dessa maneira, La Llorona traz consigo a temática de atacar e destruir os filhos, ensejando a referência de os chicanos serem sempre atacados pelo Outro, pelo estrangeiro. Segundo Anzaldúa,

\begin{abstract}
A lamentação de La Llorona pelos filhos perdidos durante a noite tem uma nota que ecoa no grito de dor ou nos ritos de luto realizados pelas mulheres enquanto elas oferecem um preço por seus filhos, irmãos ou esposos durante o adeus, antes de eles irem para as "guerras floridas". O lamento é o protesto enfraquecido da indígena, da mexicana e da chicana quando ela não tem nenhum outro recurso. Esses ritos coletivos de lamentação têm sido um sinal de resistência numa sociedade que glorificou o temor e a guerra, para aqueles cujas mulheres das tribos conquistadas, eram o saque. $(1999, \text { p. } 55)^{5}$
\end{abstract}

Sendo assim, a complexidade da situação exige que nos prolonguemos para além do entendimento racional e tentemos arrazoar a condição de La Llorona como a mãe desesperada, aquela que recupera o movimento impulsionador das histórias de matar os chicanos. Na iminência de ver seus filhos mortos por qualquer outro ser, ela mesma, num ato tresloucado, dá fim aos próprios filhos e acaba de vez com descrições idealistas padronizadas acerca de perdas de entes queridos.

Enquanto espectadores dessa triste representação, nós transpomos os contornos dos preceitos morais e percebemos o poder da mulher (chicana ou não). Junto a essa referência sangrenta está, enfim, a decifração de Anzaldúa em procurar mostrar as causas das transformações que a "fêmea" sofre em sua cultura, uma vez que a mulher passa a representar e externar toda uma série de ideologias escondidas até então.

Dessa maneira, abrem-se possibilidades para que as mães mitológicas e as mulheres possam ser consideradas vitoriosas em cruzar fronteiras, as que sobrepujam o poder do macho. Elas, agora, significam o centro dos acontecimentos sociais, o material disponível para seu poder, a determinação para o exercício de pressões sobre o Outro e o estabelecimento de suas escolhas. 
Finalmente, La Malinche, a última das mães a ser enfocada, nos é apresentada como a traidora, a que desperta do sono para articular o impossível: "vender" seu povo aos espanhóis. Fugindo da afirmação de qualquer outra verdade, La Malinche é a revelação da insistência no jogo de imagens voltado para a personificação em trair as convenções sociais. Sem que se saiba o porquê, ela renega a própria tradição e por ironia ou por desprezo, deixa que o "outro" tome conta dos "filhos" da terra. Ela é a imagem da detenção do capitalismo de mercado, pois, com o "lucro" da "venda" dos filhos, ela cria a produção material dos castelos e palácios, das armas e do controle do Outro sobre os chicanos. La Malinche é a insistência dos limites fronteiriços exercidos pelo modo de produção do dominador.

Assim, é com essa desconcertante realidade que Anzaldúa penetra no âmago de sua tradição cultural e nos faz visualizar o centro da etnia. Já não é mais o que gostaria ou não de dizer, a possibilidade de mencionar algo certo ou errado, mas a constituição do que considera essencial para dar seu grito de guerra em defesa de seu povo. Como deixar que o estrangeiro que tomou suas terras sufoque seus irmãos de sangue? Que "poder" tem esse Outro para revolucionar a casa asteca? Assim, ela comenta que "Não foi apenas o cérebro que foi dividido em dois, mas, também, a realidade. Portanto, as pessoas que habitam ambas realidades são forçadas a viverem na interface das duas, forçadas a se tornarem adeptas dos desvios. Isso é o que acontece com a indígena e com a mestiza" ["Not only was the brain split into two functions but so was reality. Thus people who inhabit both realities are forced to live in the interface between the two, forced to become adept at switching modes. Such is the case with the india and the mestiza”. ] (p. 59).

Ao contrário de portar uma máscara escondendo a ordem social estabelecida, Anzaldúa revela, neste capítulo, o essencial: sua atividade para concretizar suas lutas em prol da memória de seus ancestrais, o movimento ascendente para a constituição da Raza. Os indícios de um discurso político são sentidos como um movimento que significa um sujeito 
resvalando na direção daquilo que considera uma "mobilização social" de resgate, para não serem reduzidos a simples registros de qualquer tabela de porcentagens.

Como o jogo de sentidos sempre pressupõe um espaço "entre", ou seja, um vazio semântico que significa, o jogo estabelecido por Anzaldúa no quarto capítulo de Borderlands, "La herencia de Coatlicue - The Coatlicue State" (p. 63 a 73), articula a dualidade entre “ver e ser visto", “objeto e sujeito" (p. 64), palavras decisivas enfocando o humano e suas manifestações. Seu próprio domínio em representar a identidade do povo faz os sentidos jamais se encontrarem, pois radicaliza as aparências e afirma não se sentir normal e não ser como os outros, isto é, ela se sente como uma alienígena, uma mutante, a grande estrada que não teme os ambientes extremados ou as verdades do inconsciente. Segundo ela, "através da pedra / do céu noturno / sozinha / sozinha / nenhuma luz apenas paredes de espelho / obsidiana / esfumaçante / no espelho ela vê / uma mulher com quatro cabeças / as cabeças virando ao redor [...] / ela se curva para pegar uma pluma de si mesma [...]" - ["across the stone / the nightsky / alone / alone / no lights just mirrorwalls / obsidian / smoky / in the mirror she sees / a woman with four heads / the heads turning round and round [...] / she bends to catch a feather of herself [..]"] - (p. 63).

Diante de tantos sonhos, sentimos o impasse vivido por ela enquanto seus textos demonstram como é o buscar o caminho nesse vir-a-ser uma referência. Idealista por natureza, ela segue pelos dois lados de seus detalhes: o de criticar as deficiências e o de ser exata quando se questiona sobre os mitos ancestrais.

Para ela, essas articulações assumem o caráter de indefinidamente ampliar o campo das formações discursivas, tanto quanto o jogo das significações. A eficácia de sua segurança em narrativizar os fatos sempre esteve em não obedecer a nenhuma lógica regrada, a nenhum desempenho de normas. Além disso, ela se vê diante dos "enfrentamentos da alma" (p. 64) 
para que seus direitos culturais sejam desempenhados nesse mesmo contexto. Segundo Yúdice,

Os direitos culturais incluem a liberdade de se engajar na atividade cultural, falar a língua de sua escolha, ensinar sua lingua e cultura a seus filhos, identificar-se com as comunidades culturais de sua escolha, descobrir toda uma variedade de culturas que compreendem o patrimônio mundial, adquirir conhecimento dos direitos humanos, ter uma educação, não deixar representar-se sem consentimento ou ter seu espaço cultural utilizado para publicidade, e ganhar respaldo público para salvaguardar esses direitos. (2004, p. 41)

Anzaldúa realiza tudo isso: "fala" uma outra lingua, engaja-se nas atividades culturais, faz sua escolha, ensina a outra língua para quem se interessa em aprender. Ela preserva a cultura chicana e faz questão de mantê-la autônoma e autosuficiente. Parece afastar-se da militância consciente para, em seu lugar, deixar nascer o poder mitológico por meio do qual tem de dirigir toda sua oposição radical, sua dignidade nas atitudes de contraposições.

Assim, Anzaldúa encena, transita pelas veredas de suas imagens, difere totalmente da conduta que cruza e entrelaça o paraíso da tradição. Diferente de outros momentos artísticos, ela passa à análise de seus elementos interessando-se por fontes que nos levam a visualizar seu diferenciado mundo de escritora. Ela se expressa assim:

O espelho é um símbolo ambivalente. Ele não reproduz apenas imagens (os gêmeos que resistem a teses e antíteses); ele os contém e os absorve. Nos velhos tempos, os indígenas mexicanos produziam espelhos de vidros vulcânicos conhecidos como obsidiana. Os videntes olhavam fixamente para essas pedras até entrarem em transe. Dentro da superfície negra, lustrosa, eles viam nuvens de fumaça que revelavam parte de uma realidade relativa ao futuro da tribo e o desejo dos deuses. $(1999, \text { p. } 64)^{6}$

Anzaldúa conserva sua escrita numa performance de fusionar suas vozes e suas verdades. Única, ela se distancia de um universo monológico e assume a ideia de ser bilateral, os dois lados em uma só face de abstrações. Ainda segundo ela,

eu tinha dois ou três anos quando Coatlicue visitou minha psique pela primeira vez, quando ela "devorou-me" (e eu "caî" no submundo). Pela aparência de temor estampada no rosto de meus pais, eu soube bem cedo que alguma coisa estava fundamentalmente errada comigo. Quando fiquei mais velha, 
eu olhava dentro do espelho, temerosa de meu segredo terrivel, o pecado secreto que tentava esconder o sinal, a marca da Besta. $\left(1999\right.$, p. 64) ${ }^{7}$

Tanto quanto propõe outras verdades, Anzaldúa nomeia e nos presentifica com suas vivências mais primitivas. A questão é que, antes de mais nada, ela procura abordar aquilo que se transforma em descobrimentos próprios para reencontrar um momento de impasse e, assim, continuar nos provocando com seu jeito fascinante de fazer-se obedecer. Na sua proposta de radicalidade e de desestruturação da hegemonia do outro, ela propõe um trabalho permanente com o conflito, ou, dito de outra forma, ela propõe um trabalho de fuga de um saber destituído de conflitos.

Suas palavras soam ao infinito e essa transferência congela-nos, petrifica-nos ao mesmo tempo que instiga-nos a buscar o poético com ela. Seus textos são essências da literatura chicana, a multiplicidade que se constitui em descobrimentos. "Seu ventre macio exposto aos olhos sarcásticos de todos; eles veem, eles veem. Os olhos deles penetram-na, eles cortam-na da cabeça aos pés. Cortada. Ela está à misericórdia deles, ela não pode fazer nada para defender-se", exclama ela. ["Her softy belly exposed to the sharp eyes of everyone; they see, they see. Their eyes penetrate her; they slit her from head to belly. Rajada. She is at their mercy, she can do nothing to defend herself'.] (p. 65).

Como vemos, a tipicidade da autora recusa o racional por definição; ela tem um tempo em seu círculo social no qual a identificamos como aquele caráter possível de outras definições morais, de outras personalidades, insistentes em alguns momentos, angustiantes em outros. Anzaldúa sente a necessidade de fazer seus leitores caírem na armadilha do dicotômico e declara que seu "rosto, como a realidade, tinha um caráter múltiplo." ["Y mi cara, como la realidad, tenía un caracter multíplice”] (p. 66).

Partindo dessas reflexões, podemos reconhecer a impossibilidade de qualquer linguagem de dizer a "verdade" sobre "verdades". Podemos ter a crença que nos leva a estabelecer níveis de verdades, mas o que é válido é a determinação de nos valermos de 
interpretações. E afinal, é essa realidade que Anzaldúa descobre para levar seu trabalho textual adiante, pois, em determinado momento ela comenta que "Há muitas estratégias de defesa que o self usa para escapar à agonia da inadequação" e que ela "tem usado todas elas" ["There are many defense strategies that the self uses to escape the agony of inadequacy and I have used all of them".] (p. 67).

Se levarmos em conta um estudo desenvolvido por Freud (1981) sobre o self, poderemos entender sua finalidade ao ser empregado por Anzaldúa. Segundo o psicanalista, o "self", das Ich, referencializa duas competências interessantes. A primeira é que o eu (self) de uma pessoa como um todo deve ser distinguido do de outras pessoas (a complexidade envolvida nessa construção diz respeito a aspectos cognitivos, morais e culturais que devem ser levados em consideração). A outra competência seria a de que o self denota uma instância específica da mente caracterizada por funções especiais, uma identidade entendida como valor que dá destaque aos valores morais e às suas normas. Dessa maneira, o self se estabelece como um sistema de práticas, crenças e valores que constituem uma determinada cultura e é, portanto, neste sentido que percebemos a produção discursiva de Anzaldúa: o uso do termo não reproduz a proposta literal dessa mulher de letras, mas corresponde ao seu cotidiano e ao das pessoas, determinando a busca de coerências internas legitimando pensamentos e idealizações.

Tudo, então, passa a ser metafórico, uma vez que a "verdade" é a adequação entre a "coisa" em si e nosso intelecto. Vemos estruturado nos escritos da autora, aquele ponto polêmico que até hoje não nos permite chegar a uma única conclusão. Para ela e para nós, o universo torna-se aquele "lugar" dos acontecimentos possíveis, no tempo possível, onde "sim" e "não" coexistem. "Essa Gloria, que estará fazendo em seu quarto, com a santa e a perversa?", comenta ela. ["Esa Gloria, qué estará haciendo en su cuarto con la santa y la perversa?”] (p. 66). Anzaldúa invade-nos com sua organização discursiva mostrando-nos a 
lógica da simultaneidade. Neste momento e no seguinte há, necessariamente, algo de complexo a ser percebido para que o equilíbrio das representações continue firmando suas adequações.

É preciso que encontremos esse conceito em seu texto e lá está ele quando ela afirma que "Deusa do nascimento e da morte, Coatlicue dá e toma a vida, ela é a encarnação de processos cósmicos [...] ela representa: dualidade na vida, uma síntese da dualidade e uma terceira perspectiva - alguma coisa mais do que mera dualidade ou uma síntese da dualidade" ["Goddess of birth and death, Coatlicue gives and takes away life; she is the incarnation of cosmic processes [...] she represents: duality in life, a synthesis of duality, and third perspective - something more than mere duality or a synthesis of duality."] (p. 68). A autora esclarece mais adiante que a mesma deusa "é um símbolo da fusão de opostos: a águia e a serpente, céu e inferno, vida e morte, mobilidade e imobilidade, beleza e horror" ["she is a symbol of the fusion of opposites: the eagle and the serpent, heaven and the underworld, life and death, mobility and immobility, beauty and horror".] (p. 69).

Por meio da imagem dessas palavras, portanto, exploramos a própria palavra, descobrimos que o único referente possível para o trabalho de Anzaldúa é a palavra em si mesma, a lógica do nosso "olhar" que transforma significantes em imagens. A partir daí, é preciso que acrescentemos o pormenor de outras manifestações discursivas encontradas no capítulo, e reunamos diferentes enunciações para somarmos outras formas de representar. Acreditamos encontrar o esquema na seguinte afirmação: “Todo incremento do consciente, cada passo adiante é uma travessia, um atravessar. Sou novamente uma alienígena em um novo território" ["Every increment of consciousness, every step forward is a travesia, a crossing. I am again an alien in new territory”.] (p. 70).

Mais uma vez, percebemos o nascimento do mistério celebrado em representações discursivas; imagens culminando no espetáculo da verbalização. Durante todo o tempo, 
Anzaldúa coloca para si mesma a tarefa de transformar ideias na possibilidade real de narrar os fatos. Mais do que nunca, ela nos surpreende com o que pode ser visível e invisível; transpassa o limite de olharmos somente para aquilo que queremos ver. Ela nos oferece um olhar para além da opacidade e conclui que "há uma força maior do que o consciente I. Esse poder é meu self mais profundo, a entidade que é a soma total de todas as minhas reencarnações" ["there is a greater power than the conscious I. That power is my inner self, the entity that is the total of all my reincarnations".] (p. 72).

A dinâmica da palavra nos escritos de Anzaldúa continua seu caminho em "How to Tame a Wild Tongue" (p. 75 a 86). Neste capítulo, ela mostra o conjunto de diferentes "linguagens" ao qual ela e os chicanos em geral precisaram se adaptar caso quisessem ter melhores possibilidades de adaptação e de aceitação à cultura adotada, a dos Estados Unidos.

Realmente, muito de suas exposições expandiram-se de maneira considerável depois que ela percebeu que podia incluir em sua forma de falar, aquela "língua" capaz de fomentar a particularidade de expressar as diferentes representações culturais por meio de uma política de comunicação mais ousada. Segundo Mignolo,

\begin{abstract}
enquanto o monolinguismo das ciências sociais implica a pureza da linguagem e a transparência do sujeito conhecedor, descrevendo e explicando um objeto conhecível, um outro pensamento é, pelo contrário, a opacidade através da língua, como propõe Glissant, numa argumentação diferente mas paralela: "A língua não tem (outra) missão" a não ser aquela que lhe é atribuída pelo Estado e pela crença metafísica na transparência da linguagem científica, isto é, sua presumida capacidade de espelhar a realidade dos mundos "social" e "natural". O mundo espiritual, de acordo com essa visão, torna-se marginal em sua diferença irreconciliável com a objetividade reivindicada pelo trabalho científico. O fim do sonho da nação sobre a unidade da língua e a pureza cultural correspondente questiona, por um lado, as confiantes atividades do conhecimento disciplinar ocidental vazado nas línguas hegemônicas da segunda modernidade; e, por outro, como insinua o pensar em línguas de Khatibi, revela o anacronismo dessa crença. (2003, p. 114)
\end{abstract}

A partir dessa perspectiva, podemos dizer que Anzaldúa relaciona a necessidade de ter metas que a direcionem rumo à escalada de outras "linguagens" a fim de atingir e debater com o todo hegemônico do Outro. Enquanto segue as regras de jogo fixas da "outra" linguagem, a 
dos Estados Unidos, abre-se em sua própria língua o poder para criar os habitantes de lugares que podem prestigiar sua invenção. Anzaldúa descreve, inscreve, cria um outro ambiente que evolui continuamente. "Eu me lembro de ter sido mandada para o canto da sala de aula por "ter respondido" para a professora de inglês quando, tudo o que eu estava tentando fazer era dizer-lhe como pronunciar meu nome", denuncia ela. ["I remember being sent to the corner of the classroom for "talking back" to the Anglo teacher when all I was trying to do was tell her how to pronounce my name".] (p. 75).

Assim, Anzaldúa não apenas incorpora uma outra realidade linguística para suas "travessias", como, também, nos conecta a uma base de interesses próprios, um lugar de conexões que contribui para o desenvolvimento de um "choque" em suprir as diversidades de suas posições. Ainda segundo ela, "Até mesmo nosso povo, outros falantes de espanhol, querem colocar cadeados em nossas bocas. Eles nos deteriam por nos colocar nas malhas das regras da academia" ["Even our own people, other Spanish speakers nos quieren poner candados en la boca. They would hold us back with their bag of reglas de academia"] (p. 76).

A essas afirmações podemos opor outras representações, mais dramáticas que devem ser interpretadas de forma ativa, segundo convenções sociais nada específicas. Anzaldúa demonstra sua importância e nos lega um outro bem maior, caracterizado em responder aos que se veem fora de suas identificações. Ela enuncia, mais uma vez, que seu discurso está essencialmente ligado a um ambiente partilhado por duas formas linguísticas: o espanhol e o inglês. Assegurando essa relação, a autora argumenta:

\footnotetext{
"Pocho, traidora cultural, você está falando a língua do opressor por falar Inglês, você está arruinando a língua espanhola", tenho sido acusada por vários latinos e latinas. O espanhol chicano é considerado deficiente pelos puristas e pela maioria dos latinos, uma mutilação do espanhol.

Mas o espanhol chicano é uma língua de fronteira que se desenvolveu naturalmente. Mudança, evolução, enriquecimento de palavras novas por invenção ou adaptação criou variantes do espanhol chicano, uma nova linguagem. Uma linguagem que corresponde a um modo de viver. $\mathrm{O}$ espanhol chicano não é incorreto, é uma língua viva. $(1999, \text { p. } 77)^{8}$
} 
Como fenômeno de referência este é um privilégio seu e, assim, ela continua comentando, também, que na vida cotidiana, muitas vezes foi chamada a atenção pelo professor: ou falava o inglês fluentemente ou então, deveria voltar para o México, seu lugar de origem.

A experiência negativa não limitou sua criatividade. Ao contrário, ela reelabora seus valores, assume novas ações junto a outros chicanos/as e passa a discutir aspectos marcadamente presentes na vida de cada indivíduo/sujeito do grupo. O resultado de seu trabalho é, na verdade, um processo discursivo (infinito) de aproximação do objeto estudado.

Ela, agora, tem um novo propósito - não ser mais aquela menina que sequer respondia para os pais. Esse seu pedaço de mundo ficou para trás. Não precisa dizer "nosotros" quando for se referir às chicanas e não mais ficar calada diante de um discurso machista. Sua relação com os novos valores sócio-culturais devem fazer lembrar, doravante, a luta sobretudo do chicano/a na sociedade americana. Na prática, não poderá mais ficar parada e ser encarada como inferior, perigosa, mas

sim, ter sua própria forma de representações.

Assim, foram criados discursos que refletissem as "verdades" de sua sociedade chicana. Havia surgido uma linguagem secreta com a qual eles, os chicanos, se comunicavam entre si, uma variação do inglês e do espanhol. Por isso mesmo, Anzaldúa tece o seguinte comentário:

E pelo fato de sermos uma raça complexa, heterogênea, falamos muitas línguas. Algumas das línguas que falamos são:

1. o inglês

2. o inglês da classe trabalhadora e as gírias

3. o espanhol padrão

4. o espanhol mexicano padrão

5. o dialeto espanhol mexicano do norte

6. o espanhol chicano (o Texas, o Novo México, o Arizona e a Califórnia apresentam variações regionais)

7. o tex-mex

8. o Pachuco (chamado caló). (1999, p. 77) ${ }^{9}$ 
Fica claro que cada um desses universos criados vai provocar posturas dicotômicas e a própria Anzaldúa comenta que usa uma língua ou outra para se comunicar com seus "irmãos": “Minhas línguas 'caseiras’ são as linguagens que eu falo com minhas irmãs e irmãos, com meus amigos. Elas são as últimas da lista de cinco, das 6 ou 7 mais próximas de meu coração", exclama ela. ["My "home" tongues are the languages I speak with my siter and brothers, with my friends. They are the last five listed, with 6 and 7 being closest to my heart".] (p. 78).

As palavras devem assumir, portanto, seus próprios significados nos vários discursos considerados. A construção de significados e a veiculação de valores fica a cargo daquele que continuar lendo seu discurso. Assim, as manifestações ganham pluralidades de significações transportadas pelas palavras nos enunciados da realidade objetiva. Já não se trata mais de um "escândalo", mas de uma autoridade linguística circulando na nova sociedade, embora Anzaldúa demonstre sua frustração ao evidenciar que essas linguagens, para o estrangeiro, não são levadas em conta para efetivar possibilidades de mudança. Assim, ela comenta o seguinte:

Deslenguadas. Somos los del español deficiente. Somos seu pesadelo linguístico, sua aberração linguística, suas mestiçagens linguísticas, o sujeito de sua zombaria. Pelo fato de falarmos línguas de fogo somos culturalmente crucificados. Somos órfãos racialmente, culturalmente e linguisticamente falamos uma língua órfã. $(1999, \text { p. } 80)^{10}$

Entretanto, o resultado desse processo demonstrará a existência de indivíduos socialmente organizados que vão fazer um tipo de "contrato" entre si, e fazer surgir as muitas “vozes" consideradas necessárias para se discutir, sobretudo, a história da formação e da luta do povo chicano. Ele vai explorar recursos para solucionar esses problemas locais como também demandará representações adequadas à comunidade, ou seja, exercerá os direitos de propriedade cultural relativos às experiências vividas. Com essas representações, os chicanos alegam que os norte-americanos não têm o direito de dizer quem são os chicanos e tampouco 
como devem formatar sua identidade. A própria Anzaldúa confessa que viu nascer nela mesma a "voz: Indígena, Espanhola, branca. Eu terei minha língua de serpente - minha voz de mulher, minha voz sexual, minha voz de poeta. Eu superarei a tradição do silêncio" ["I will have my voice: Indian, Spanish, white. I will have my serpent's tongue - my woman's voice, my sexual voice, my poet's voice. I will overcome the tradition of silence".] (p.81).

Sendo assim, na acepção da autora, fica o procedimento de querer impor a língua e a literatura dos chicanos para outras comunidades enquanto ministrava suas aulas, embora corresse o risco de ficar desempregada.

Mais uma vez, essas diversas situações fazem-na perceber que para defender sua própria ideologia, ela precisa considerar o processo de mudança, muitas vezes lento, mas que tem surtido efeitos consideráveis em prol dela mesma e de sua Raza. A Raza que determina como a efervescência de ideias, principalmente opostas à originalidade estadunidense, mostra a existência de sua tradição indígena e espanhola e discute sobre essa cultura transformadora de abstrações que realiza todo tipo de troca: cultural, linguística, econômica, social, E nesse mesmo movimento, Anzaldúa reelabora sua teoria levando às últimas consequências o legado da tradição de que pensar sua cultura é uma atividade material embasada na própria sociedade chicana.

Ela reconhece essas transformações e comenta que ser chicano, antes de qualquer outra coisa, é ser uma raça. "Entre nós não dizemos nós os americanos, ou nós os espanhóis, ou nós os hispânicos. Dizemos nós os mexicanos (por mexicanos não queremos dizer cidadão do México; não significamos uma identidade nacional, mas uma identidade racial)" ["Among ourselves we don't say nosotros los americanos, o nosotros los españoles, o nosotros los hispanos. We say nosotros los mexicanos (by mexicanos we do not mean citizens of México; we do not mean a national identity, but a racial one)".] (p. 84). 
Desse modo, podemos observar que, ao passar por todas essas mudanças, Anzaldúa deixa registrada em sua escritura, a garantia de uma dose de permanência do passado histórico, pois o novo apresenta-se como o resultado das possibilidades de manifestações do velho. Mais uma vez ela se pronuncia: "nós não nos identificamos com os valores culturais anglo-americanos e não nos identificamos totalmente com os valores culturais mexicanos. Somos uma sinergia de duas culturas com vários graus de mexicanês ou de anglonês." ["we don't identify with the Mexican cultural values. We are a synergy of two cultures with various degrees of Mexicannes or Angloness".] (p. 85).

Sendo assim, por si só, a palavra chicano está na raiz da sociedade e para desenvolver a prática de sê-lo, há que se relacionar com a sociedade, fora do indivíduo isolado, e, mais uma vez, Anzaldúa demonstra seu saber a respeito disso tudo: "Não obstante a luta por identidade continue, a luta por fronteiras ainda é nossa realidade" ["Yet the struggle of identities continues, the struggle of borders is our reality still”.] (p. 85).

Em "Tlilli, Tlapalli, The Path of the Red and Black Ink"11 (p. 87 a 97), Anzaldúa objetiva exibir seu relacionamento com a escrita; afirmar mais uma vez que sua proposta literária é trespassar o corpo desintegrado das ausências históricas e deitar o olhar para além da tendência à inércia. Ela objetiva aproximar-nos, mais uma vez, de outras verdades acerca dela mesma evidenciando seus outros diálogos para, assim, assenhorar-se de sua autêntica voz chicana.

Aqui, ela muda seu tom, dialoga com novas narrativas, faz erguer um segundo plano, sai do primeiro para poder aproximar-se do interior de sua palavra. Anzaldúa sabe desde o início que precisa determinar a construção de seu discurso e concentra suas energias para isso não ser interrompido. Ela nos estimula com suas histórias especialmente com aquelas que narram o momento das manifestações de realidade enquanto criança. Ela se pronuncia assim: 
Quando eu tinha sete, oito, nove, quinze, dezesseis anos, eu costumava ler na cama com uma lanterna acesa sob as cobertas para esconder minha auto-imposta insônia de minha mãe. Eu preferia o mundo da imaginação à morte do sono. Minha irmã, Hilda, que dormia comigo na mesma cama, ameaçava contar à mamãe caso eu não lhe contasse uma história. $\left(1999\right.$, p. 87) ${ }^{12}$

É como se a narrativa de Anzaldúa desconhecesse a mentira, os vícios, a crise do utópico. É como se o que ela retrata fosse a pureza das personagens da sua realidade, da natureza, entremeada de sonhos a serem conquistados. Para a autora, a unidade a ser representada soa como a integridade do conjunto do herói, a possibilidade de surgimento de uma outra vida totalmente diferente das diversas injunções literárias. Entre o mistério e o oculto, uma nova força gerada por ela mesma é capaz de transmitir e de ampliar um simples movimento das ações inseridas no enredo. Anzaldúa comenta:

Eu vejo uma hibridização de metáforas, diferentes espécies de idéias pipocando aqui e ali, cheia de variações parecendo contradições, embora eu acredite em um universo ordenado, estruturado onde todos os fenômenos estão inter-relacionados e imbuídos de espírito. $(1999, \text { p. } 88)^{13}$

Os objetos apresentados, como vemos, são roupas ou veículos dos quais Anzaldúa lança mão para que possa recortar o contexto histórico-social e inserir sua história em um grande cenário vivo. O que ela designa é atribuído aqui e acolá como a maneira de ela privilegiar o nascimento do inaudito, prenúncio de sua escritura. Como era comum ela ouvir histórias narradas pela avó, acostumou-se tanto a esse fato que, para preservar a imortalidade daquelas personagens, vê-se impelida a continuar narrando.

Assim, a atemporalidade de suas narrativas marca a presença harmoniosa para fazer surgirem histórias narradas em prosa e verso, combatentes produzindo tipos de escritura mais puros, propostas estas que nos fazem identificar o hibridismo metafórico conectando seus textos. A escrita de Anzaldúa é a referência que a palavra procura para representar todo um parêntese de postulados anteriores. Com sua escrita, os grandes temas revolucionários se encontram fecundados para misturarem a linguagem do verossímil. 
Com isso, a natureza textual integrada às suas ideias e ideais, encadeia as situações a que ela dá vida para transformar a ausência, o vazio, em uma evolução cultural. De seu discurso emerge uma preocupação de articular formas poéticas sustentadas pelo enredo. As circunstâncias da vida tornam-se circunstâncias em que a verdade exige formas próprias para amplificar o signo dos acontecimentos. Ela comenta:

\begin{abstract}
Minhas "histórias" são atos encapsulados no tempo, "ordenados" a qualquer tempo, são ditos em voz alta ou lidos silenciosamente. Gosto de pensá-los como desempenho e não como objetos inertes e "mortos" (como a estética da cultura ocidental pensa das obras de arte). Ao invés disso, o trabalho tem uma identidade; ele é um "quem" ou um "o quê" e carrega as presenças de pessoas, isto é, encarnações de deuses e ancestrais ou poderes naturais e cósmicos. O trabalho manifesta as mesmas necessidades de uma pessoa, ele precisa ser "alimentado", Tenho que banhá-lo e vesti-lo. $\left(1999\right.$, p. 89) ${ }^{14}$
\end{abstract}

Por meio dessas partes integrantes, Anzaldúa modifica, para além de suas histórias, o mundo exterior e, ao modificá-lo, transforma a própria maneira de manifestar-se. Como parte integrante de uma realidade cultural chicana, ela considera-se a mediação entre sujeito e objeto, entre dar-se a entender e ser entendida. Ela afirma que as palavras viajam de boca em boca, de ideologia em ideologia. Assim, as lutas estão, entre si, cada vez mais fazendo alianças umas com as outras. Por meio dessa internalização, as participações artísticas resultam nas externalizações do mundo social ligadas a uma ação, a uma escritura que, depressa, torna-se uma linguagem de valor.

Dessa forma, como ela tem observado, o etnocentrismo passa a ser a "tirania da estética ocidental" ["Ethnocentrism is the tyranny of Western aesthetics"], assim como "Pintores ocidentais modernos "emprestaram", copiaram, ou extrapolaram a arte das culturas tribais e chamaram-na de cubismo, surrealismo, simbolismo" ["Modern Western painters have "borrowed", copied, or otherwise extrapolated the art of tribal cultures and called it cubism, surrealism, symbolism”.] (p. 90). Parece que o essencial aqui, é mostrar como aquela estética apresenta um caráter de fechamento, totalmente estranho àquele que deseja intervir 
nessas instâncias fechadas, para poder mudar. Anzaldúa é conhecida por seu "caráter" mutante, por sua voz diferenciada, por seu gênero híbrido.

Sob esse aspecto, o processo de formação de sua obra demonstra as possibilidades de complementação histórica a respeito da cultura chicana. Por meio desse estudo, percebemos como ela se revela enquanto "voz", emoção, imaginação, autopercepção, demonstração do outro e expressão. Por meio de seu discurso (re)aprendemos o literário para ampliarmos nossos instrumentos de entendimento em relação ao seu trabalho. Aquilo que tinha ficado interditado pela hegemonia do Outro, agora aparece como o discurso móvel, que suscita sentidos designando o objetivo de ela se pronunciar sobre sua escrita, sobre a maneira de conseguir o inédito, a transparência de outros trechos. Segundo a autora,

\footnotetext{
Uma imagem é uma ponte entre a emoção evocada e o conhecimento consciente; as palavras são os cabos que sustentam a ponte. As imagens são mais diretas, mais imediatas do que as palavras e mais próximas do inconsciente. A linguagem pictórica precede o pensar em palavras; a mente metafórica precede a consciência analítica. $(1999, \text { p. } 91)^{15}$
}

Precisamos perceber, portanto, que Anzaldúa tem outras tarefas. Como ela mesma aponta, se ela fica vários dias sem anotar as imagens que lhe vêm à mente, sente-se fisicamente doente. Para ela, "escrever é um ato sensual" ["Writing Is A Sensuous Act"] (p. 93), assim como tem de confiar e acreditar em si mesma "como um falante, como uma voz para as imagens" e que pode comunicar-se "com imagens e palavras" e pode "fazê-lo bem" ["I have to trust and believe in myself as a speaker, as a voice for the images. I have to believe that I can communicate with images and words and that I can do it well”.] (p. 95).

Dessa forma, sua permanente conexão do trabalho com a vida demonstra um processo particular de atividades a fim de descrever o território interno, não-literal a que se propõe expressar. Para ela e para nós, essa nova forma resulta em alguma coisa visível que proporciona outras clarezas, outras interações de não-silenciamento. Anzaldúa declara: 
Até que uma outra agulha perfure a pele. Isso é o que escrever é para mim, um círculo sem fim de fazê-lo pior, de fazê-lo melhor, mas sempre fazê-lo significar pela experiência, o que quer que isso possa ser.

Minhas flores não poderão deixar de viver;

minhas canções nunca terão fim:

Eu, um cantor, as entôo;

elas se espalham, elas se difundem.

-Cantares mexicanos. $(1999, \text { p. } 95)^{16}$

Por fim, cumprindo seu papel de desenhar um meio perturbador a nos fazer investigar novas tendências sobre sua narrativa, Anzaldúa fecha os capítulos em prosa com o texto " $\mathbf{L a}$ consciencia de la mestiza / Towards a New Consciousness" (p.99 a 113). Aqui, ela contribui com sua mais decisiva visão para totalizar sua escrita sobre a cultura chicana, instância fundamental em um processo de mudanças sociais a ser substancializada por sua marca de afiliação a essa mesma cultura. Anzaldúa é rígida ao escrever sobre a influência que se espalhou entre os indivíduos da comunidade para criticar e compreender a própria cultura. Política partidária inserida na resistência de defender seu povo, ela pronuncia o seguinte:

\author{
Pelo fato de eu, uma mestiza \\ continuamente sair de uma cultura \\ e entrar em outra, \\ estou em todas elas ao mesmo tempo, \\ alma entre dois mundos, três, quatro, \\ zumbe-me a cabeça com o contraditório. \\ Estou norteada por todas as vozes que me falam \\ simultaneamente. $(1999, \text { p. } 99)^{17}$
}

Partindo do princípio de que é preciso identificarmos o texto da autora como um discurso híbrido que narra as histórias da cultura chicana, é na produção desse debate que a encontramos interessada em tomar sua própria posição: mostrar as implicações políticas das quais dispõe para avaliar a produção discursiva sobre sua cultura, os diferentes pontos de vista aos quais o leitor pode recorrer para entender os diferentes objetivos da autora. 
Podemos perceber a "mestiça" que existe nela e o hibridismo de duas culturas existentes em cada chicano, o que a faz adotar uma postura para debater abertamente essa formação única enquanto intelectual que estuda a formação de uma Raza, o chicano.

Segundo ela, vítima de injustiças sociais e de negligência, Anzaldúa tem buscado, em sua trajetória, a dimensão mágico-onírica que demonstre os problemas resultantes de uma "ditadura" hegemônica do Outro, quando ela tenta se colocar para ter sua voz, ou a capacidade de contenção e de controle de seus excessos. Conciliando ambientes realistas com o envolvimento de seus sonhos, a autora dimensiona diversas configurações, prontas para abordarem o desconhecido. Seu maior problema, entretanto, é comparar o imaginado pela memória cultural a uma apresentação etnicamente diversificada. Essa memória reserva-nos o que sobreviveu do passado da tradição e serve de ponte para a recuperação da mestiza no presente. De acordo com Anzaldúa,

\footnotetext{
A mestiza suporta uma batalha de instantes, uma batalha de fronteiras, uma guerra mais interior. Como todas as pessoas, nós percebemos uma versão da realidade que nossa cultura comunica. Como outros que têm ou vivem em mais de uma cultura, nós recebemos múltiplas mensagens, sempre opostas. O vir junto de dois auto-coerentes mas habitualmente incompatíveis quadros de referência, causa um choque, uma colisão cultural. $(1999, \text { p. 100) })^{18}$
}

Vemos que ela, a sobrevivente desses contextos, integra-se de modo essencial a uma construção da memória híbrida, a um trabalho de campo tão infinito quanto o da memória. Anzaldúa se despoja do ódio e da violência inútil destinada a causar dor para que, nesse lugar, surjam paixões explicando as misturas dos sistemas de diferenciação.

Ela contesta os valores do outro e tenta organizar o caos das experiências vividas, embora se revele adepta de uma visão ambivalente. E mais: toda sua escrita parece estar relacionada a uma articulação de subjetividade que fica difícil modelar seu respectivo produto literário de maneira autoritária. 
Anzaldúa é bélica, coloca armadilhas em sua máquina de desleituras: nós, leitores, nunca sabemos como nos comportar diante de seu hibridismo, de sua vertiginosa trilha de leituras. Pulando de um ponto a outro não conseguimos abandonar ou sequer terminar a leitura do real inscrito em sua mestiçagem. Disposta a praticar uma literatura de fronteiras, ela exclama que,

A nova mestiza [...] pode derramar-se em ambivalências por meio de um intenso, e sempre doloroso evento emocional que inverte ou resolve a ambivalência. Não tenho certeza exatamente como. O trabalho acontece no submundo - subconscientemente. É o trabalho que a alma realiza. Aquele ponto focal ou fulcral, aquela juntura onde a mestiza se encontra, onde os fenômenos tendem a colidir. (1999, p. 101$)^{19}$

Defensora de uma personalidade múltipla para formar o chicanismo, ela já se percebe parte de um elo que sustenta a corrente determinadora dos vários relacionamentos quando se vive na "fronteira" física e psicológica de uma cultura em ascensão. Desenvolve, por isso mesmo, a consciência de perceber a existência de grupos organizados em suas relações sociais e comenta que "como mestiça não tenho país, [...]"e "como lésbica não tenho raça" ["As a mestiza I have no country [...], As a lesbian I have no race, [...]”.]; seu próprio povo a nega em determinadas ocasiões (p. 102).

Assim, nesse teatro conduzido pela magia do espetáculo cultural, ela perceberá a independência de suas significações criadas pela própria escrita. Percebe, também, a necessidade de acabar com as ideias de obras-primas criadas a partir de uma hegemonia e usa, pelo discurso, sua arte em se projetar acusadora do que considera erros a serem evitados pelos seus contemporâneos. Mais do que nunca, a autora questiona-se a respeito do que foi herdado de seus ancestrais e percebe o peso de precisar carregar o fardo da bagagem de uma mãe indígena (sua cultura), mesclada à bagagem de um pai espanhol (com a invasão dos espanhóis) e à vivência na língua inglesa. 
Mesclada, é impossível que seus testemunhos não sirvam para introjetar a colonização e o colonizador, ambos materiais de uma escritura que não quer calar as denúncias das desavenças sofridas. O que se propaga em seu discurso é todo tipo de violência sofrida em terras estrangeiras, os espectros de uma prisão cuja liberdade só aconteceria pela morte. "Indígena como o milho, como o milho, a mestiza é um produto de criação, designada à preservação sob uma variedade de condições”, exclama ela mais uma vez ["Indigenous like corn, like corn, the mestiza is a product of crossbreeding, designed for preservation under a variety of conditions".] (p. 103).

Suas realizações passam a suprir, dessa maneira, o elevado potencial de conservar a luta da mestiça acima de qualquer outra luta feminista. Por meio da palavra ela mostra que "ser chicano é ser um povo" ["Somos una gente"], e que os brancos, por isso mesmo, precisam fazer alianças, aceitar o fato de sua cultura ser diferente enquanto diferentes que são (p. 107).

É, portanto, diante dessa materialidade discursiva, nesse horizonte ideológico fora de qualquer época e de qualquer grupo social pré-estabelecido que encontramos Anzaldúa afirmando que não há só uma verdade (a do branco), mas uma variedade delas.

Por que, então, a cultura branca está matando a chicana devagarzinho com sua ignorância, pergunta a autora? Parece que a partir desse questionamento ela mesma responde encarando o presente como a reconstrução dos vencidos que no futuro terão de voltar os olhos para ver a própria história chicana sendo reformulada por um outro ângulo. Para sustentar o insustentável, ela partilha conosco:

Crescimento, morte, decomposição, nascimento. O solo preparado repetidamente, impregnado, trabalhado. Uma constante mudança de formas, renascimento da terra mãe.

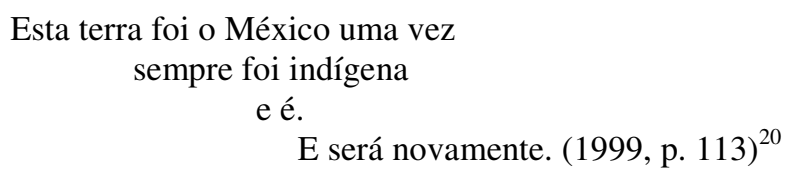




\section{NOTAS}

1- "Today thousands of Mexicans are crossing the border legally and illegally; ten million people without documents have returned to the Southwest. Faceless, nameless, invisible, taunted with "Hey cucaracho" (cockroach). Trembling with fear, yet filled with courage, a courage born of desperation. Barefoot and uneducated, Mexicans with hands like boot soles gather at night by the river where two worlds merge creaitng what Reagan calls a frontline, a war zone. The convergence has created a shock culture, a border culture, a third country, a closed country". (ANZALDÚA, 1999, p. 33)

2- "La mojada, la mujer indocumentada, is doubly threatened in this country. Not only does have to contend with sexual violence, but like all woman, she is prey to a sense of physical helplessness. As a refugee, she leaves the familiar and safe homeground to venture into unknown and possibly dangerous terrain.

This is her home

This thin edge of

barbwire". (ANZALDÚA, 1999, p. 34-35)

3- "Pulque, ou octli, é uma bebida alcoólica feita do suco fermentado da maguey (agave americana), usada tradicionalmente na Mesoamérica. Muito antes da conquista espanhola, a pulque era consumida nas cerimônias religiosas. Jarros para guardá-la tinham, freqüentemente, a forma de macaco para refletir o inebriante efeito da bebida. Muitos autores pensam que a primeira sílaba da palavra México se origina da palavra nahuatl, maguey. A razão para que esta raiz tenha seduzido muitos autores, é que no Código Mendocino, o fundador mítico do México é representado como um maguey (metl), sobre as costas Tzin (tli), isto é, Metzin ou Mexitzin. Igualmente, pelo fato de que a planta maguey tem relação com uma agricultura estável". (disponível em <http://www.germandiego.s5.com/pulque/acapulquito.htm $>$ ) Acesso em: 10.ago.2008.

4- "In 1660 the Roman Catholic Church named her Mother of God, considering her synonymous with la Virgen María; she became la Santa Patrona de los mexicanos. The role of defender (or patron) has traditionally been assigned to male gods. During the Mexican Revolution, Emiliano Zapata and Miguel Hidalgo used her image to move el pueblo mexicano toward freedom. During the 1965 grape strike in Delano, California and in subsequent Chicano farmworkers' marches in Texas and other parts of the Southwest, her image on banners heralded and united the farmworkers. Pachucos (zoot suiters) tattoo her image on their bodies. Today, in Texas and Mexico she is more venerated than Jesus or God the Father". (ANZALDÚA, 1999, p. 51)

5- "La Llorona's wailing in the night for her lost children has an echoing note in the wailing or mourning rites performed by women as they bade their sons, brothers and husband good-bye before they left to go to the "flowery wars". Wailing is the Indian, Mexican and Chicana woman's feeble protest when she has no other recourse. These collective wailing rites may have been a sign of resistance in a society which glorified the warrior and war and for whom the women of the conquered tribes were booty". (ANZALDÚA, 1999, p. 55)

6- "The mirror is an ambivalent symbol. Not only does it reproduce images (the twins that stand for thesis and antithesis); it contains and absorbs them. In ancient times the Mexican Indians made mirrors of volcanic glass known as obsidian. Seers would gaze into a mirror until they fell into a trance. Within the black, glossy surface, they saw clouds of smoke which would part to reveal a vision concerning the future of the tribe and the will of the gods". (ANZALDÚA, 1999, p. 64)

7- "I was two or three years old the first time Coatlicue visited my psyche, the first time she "devoured" me (and I "fell" into the underworld). By the worried look on my parents' faces I learned early that something was fundamentally wrong with me. When I was older I would look into the mirror, afraid of mi secreto terrible, the secret sin I tried to conceal - la seña, the mark of the Beast". (ANZALDÚA, 1999, p. 64)

8- "Pocho, cultural traitor, you're speaking the oppressor's language by speaking English, you're ruining the Spanish language", I have been accused by various Latinos and Latinas. Chicano Spanish is considered by the purist and by most Latinos deficient, a mutilation of Spanish. 
But Chicano Spanish is a border tongue which developed naturally. Change, evolución, enriquecimiento de palabras nuevas por invención o adopción have created variants of Chicano Spanish, un nuevo lenguaje. Un lenguaje que corresponde a un modo de vivir. Chicano Spanish is not incorrect, it is a living language". (ANZALDÚA, 1999, p. 77)

9- "And because we are a complex, heterogeneous people, we speak many languages. Some of the languages we speak are:

1. Standard English

2. Working class and slang English

3. Standard Spanish

4. Standard Mexican Spanish

5. North Mexican Spanish dialet

6. Chicano Spanish (Texas, New Mexico, Arizona and California have regional variations)

7. Tex-Mex

8. Pachuco (called caló)". (ANZALDÚA, 1999, p. 77)

10- "Deslenguadas. Somos los del español deficiente. We are your linguistic nightmare, your linguistic aberration, your linguistic mestizaje, the subject of your burla. Because we speak with tongues of fire we are culturally crucified. Racially, culturally and linguistically somos huérfanos - we speak an orphan tongue". (ANZALDÚA, 1999, p. 80)

11- Anzaldúa aponta que, "Para os antigos astecas, tlilli, tlapalli, a tinta preta e vermelha de seus códices (a tinta preta e vermelha pintada nos códices), eram as cores simbolizando escrita e sabedoria (a escrita e a sabedoria) [...] Uma imagem é uma ponte entre a emoção evocada e o saber consciente; as palavras são cabos que sustentam a ponte. As imagens são mais diretas, mais imediatas que as palavras, e mais próximas do inconsciente. A linguagem pictórica vem antes do pensar com palavras; a mente metafórica precede a consciência analítica [...] Eu escrevo o mito em mim, nos mitos que sou, os mitos nos quais quero me transformar. A palavra, a imagem e o sentimento têm uma energia saborosa, um tipo de poder." ["For the ancient Aztecs, tlilli, tlapalli, la tinta negra y roja de sus códices (the black and red ink painted on codices) were the colors symbolizing escritura y sabiduría (writing and wisdom) [...] An image is a bridge between evoked emotion and conscious knowledge; words are the cables that hold up the bridge. Images are more direct, more immediate than words, and closer to the unconscious. Picture language precedes thinking in words; the metaphorical mind precedes analytical consciousness [...] I write the myths in me, the myths I am, the myths I want to become. The word, the image and the feeling have a palpable energy, a kind of power'] (p. 91 a 93)

12- "When I was seven, eight, nine, fifteen, sixteen years old, I would read in bed with a flashlight under the covers, hiding my self-imposed insomnia from my mother. I preferred the world of the imagination to the death of sleep. My sister, Hilda, who slept in the same bed with me, would threaten to tell my mother unless I told her a story”. (ANZALDÚA, 1999, p. 87)

13- "I see a hybridization of metaphor, different species of ideas popping up here, popping up there, full of variations and seeming contradictions, though I believe in an ordered, structured universe where all phenomena are interrelated and imbued with spirit". (ANZALDÚA, 1999, p. 88)

14- "My "stories" are acts encapsulated in time, "enacted" every time they are spoken aloud or read silently. I like to think of them as performances and not as inert and "dead" objects (as the aesthetics of Western culture think of art works). Instead, the work has an identity; it is a "who" or a "what" and contains the presences of persons, that is, incarnations of gods or ancestors or natural and cosmic powers. The work manifests the same needs as a person, it needs to be "fed", la tengo que bañar y vestir”. (ANZALDÚA, 1999, p. 89)

15- "An image is a bridge between evoked emotion and conscious knowledge; words are the cables that hold up the bridge. Images are more direct, more immediate than words, and closer to the unconscious. Picture language precedes thinking in words; the metaphorical mind precedes analytical consciousness". (ANZALDÚA, 1999, p. 91) 
16- "Until another needle pierces the skin. That's what writing is for me, an endless cycle of making it worse, making it better, but always making meaning out of the experience, whatever it may be.

My flowers shall not cease to live;

my songs shall never end:

I, a singer, intone them;

they become scattered, they are spread about.

--- Cantares mexicanos". (ANZALDÚA, 1999, p. 95)

17- "Because I, a mestiza, / continually walk out of one culture / and into another, / because I am in all cultures at the same time, / alma entre dos mundos, tres, cuatro, / me zumba la cabeza con lo contradictorio. / Estoy norteada por todas las voces que me hablan / simultáneamente”. (ANZALDÚA, 1999, p. 99)

18- "la mestiza undergoes a struggle of flash, a struggle of borders, an inner war. Like all people, we perceive the version of reality that our culture communicates. Like others having or living in more than one culture, we get multiple, often opposing messages. The coming together of two self-consistent but habitually incompatible frames of reference causes un choque, a cultural collision". (ANZALDÚA, 1999, p. 100)

19- "The new mestiza [...] can be jarred out of ambivalence by an intense, and often painful, emotional event which inverts or resolves the ambivalence. I'm not sure exactly how. The work takes place underground - subconsciously. It is work that the soul performs. That focal point or fulcrum, that juncture where the mestiza stands, is where phenomena tend to collide". (ANZALDÚA, 1999, p. 101)

20- "Growth, death, decay, birth. The soil prepared again and again, impregnated, worked on. A constant changing of forms, renacimientos de la tierra nadre.

This land was Mexican once

was Indian always

and is.

And will be again”. (ANZALDÚA, 1999, p. 113) 


\subsection{Por uma voz que se quer independente: a alteridade em Anzaldúa}

As atuais discussões sobre o modo de se narrar parecem estar voltadas para perturbadoras complexidades, pois pela necessidade de encarar a paradoxal natureza dos próprios assuntos, parte da arte narrativa pós-moderna encontra-se envolvida e caracterizada pelo revisitar dos acontecimentos da história.

Em todos seus aspectos, as vozes narrativas mais relevantes da contemporaneidade trabalham em direção a um esteticismo que tenta dialogar com o passado tanto quanto com o contexto sócio-ideológico do presente que permitam ao narrador, falar a partir de um local cujas possibilidades discursivas confrontem relações com o mundo da significação.

Mais do que isso, segundo a tradição literária, as narrativas produzem um determinado saber à medida que expressam e indicam um discurso público que, por meio da narratividade, passam a estabelecer a realidade das coisas conforme se produzam discursivamente.

No discurso atual, o espaço do eu e do Outro estão sempre disponíveis para serem preenchidos pelos efeitos da "verdade" que, via de regra, circulam entre a legalidade e a ilegalidade discursivas, a fim de reproduzir o efeito de sentido.

Comprometidas com aquilo que tentam descrever, parte das narrativas pós-modernas são capazes de, ao mesmo tempo, criticar sua dependência em relação à antiga estética literária, assim como assumir novas posições para "testemunhar” sobre zonas geográficas, raciais, políticas, e culturais. De acordo com Hutcheon,

\footnotetext{
ao contestar implicitamente [...] conceitos como a originalidade estética e o fechamento do texto, a arte pós-modernista apresenta um novo modelo para demarcação da fronteira entre a arte e o mundo, um modelo que atua a partir de uma posição que está dentro de ambos e, apesar disso, não está inteiramente dentro de nenhum dos dois, um modelo que está profundamente comprometido com aquilo a que tenta descrever, e apesar disso ainda é capaz de criticá-lo. (1991, p. 43)
}

Tentando investigar de quem é a verdade daquilo que se conta, procuramos saber porque os fatos combinam contradições, como eles aconteceram, como foram construídos, 
qual o grau de autenticidade pelo qual se dão a conhecer e que tipo de perguntas podemos lançar-lhes, para conhecermos os objetos que fundamentam esse ou aquele passado, histórico ou não, tradicional ou contemporâneo.

Sob esse ponto de vista, as histórias dependem de como encaramos o narrador que apresenta o fato e como as coisas passadas, que não podem desaparecer com o tempo, conseguem se acumular e influir no presente. Ainda segundo Hutcheon,

o que o pós-modernismo faz é contestar a própria possibilidade de um dia conseguirmos conhecer os "objetos fundamentais" do passado. Ele ensina e aplica na prática o reconhecimento do fato de que a "realidade" social, histórica e existencial do passado é uma realidade discursiva quando é utilizada como o referente da arte, e, assim sendo, a única "historicidade autêntica" passa a ser aquela que reconheceria abertamente sua própria identidade discursiva e contingente. O passado como referente não é enquadrado nem apagado, como Jameson gostaria de acreditar: ele é incorporado e modificado, recebendo uma vida e um sentido novos e diferentes. (1991, p. 45)

Assim, o narrador pós-moderno decide de quais estruturas ele deve lançar mão para transformá-las em individualidades possíveis de serem culturalmente aceitas e, desse lugar, manifestar outras "verdades" que até então não eram conhecidas pela comunidade.

As narrativas mantêm as estratégias de representarem as culturas que, enquanto objetos a serem transculturalizados, ambas, culturas e narrativas, operam fundamentais transformações.

Construindo novas formas, textos pós-modernos acabam produzindo uma representação com alcance universal para mostrar os acontecimentos que estabelecem e significam a própria transformação da realidade.

Segundo Reis (2005), não se trata apenas de as narrativas adotarem uma mudança linguística, ou de reconstruírem uma linguagem literária, mas sim, de mostrar as "verdades" e as reações culturais que apregoam o nascimento de novas maneiras de "olhar" o fato.

Depois, como aponta Reis, a narrativa e a poesia destacam-se por significar os tênues limites de estruturas que, já modificadas, enfocam as ideologias das personagens contando 
suas próprias histórias. Dessa vez, o tradicional monólogo discursivo cedeu lugar a uma estruturação narrativa em que oral, popular e cânone se fundem para, de um jeito livre, poderem narrar sobre as condições sócio-econômicas, políticas e culturais da coletividade. Para além da presença do objeto, é dimensionado o "povo" como constituinte de um "objeto histórico" a ser discutido por todos.

Finalmente, a cosmovisão narrativa incorpora as novas ideias que, analisadas sob o prisma da polaridade, reordenam o passado para poder apresentar as novas correlações referenciais. Com essa (re)organização, articulam-se as heterogeneidades que nos fazem supor que as narrativas não acontecem de forma natural, e sim, pelo efeito de uma (re)produção enunciada sob um certo gerenciamento discursivo.

Partindo dessa perspectiva, o que podemos sugerir nesse espaço de significações são os seguintes aspectos: a que objeto do passado a narrativa discute seu pertencimento? Ou, então, a que tipo de textualidade anterior se faz necessário sua referência, para que surja um significado diferenciado daquele antigo fantasma hegemônico ligado ao perpétuo movimento eurocêntrico?

$\mathrm{O}$ roteiro estruturado para nossa orientação mostra-nos que a heterogeneidade da narrativa pós-moderna dialoga com todas essas teses, e é disso que precisamos para identificarmos a infinita inventividade de Anzaldúa quando (re)cria a história do povo chicano e sua cultura.

Ao assumir uma nova posição discursiva, a autora nos mostra a emaranhada rede das discussões sobre a própria tradição, institui um novo lugar teórico intelectualizado e ativista que lhe dá voz para contar sobre suas preocupações e, ainda, lida com a multiplicidade de limites competindo entre si, para dirigir seus horizontes. 
Desse ponto de vista, Anzaldúa inicia seu relato "The Homeland, Aztlán El outro México” (p.23 a 35), citando uma estrofe de música cantada pelo conjunto "Os Tigres do Norte", que diz o seguinte:

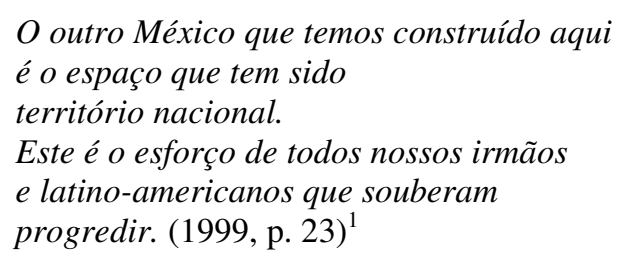

Embora o relato acima ofereça uma reivindicação nacionalista de ter de volta a "terra mãe", ele mostra tanto uma posição teórica repleta de contestações e recriminações a respeito de uma suposta subalternidade chicana, quanto um estado múltiplo de saber lidar e competir com o Outro. Além da existência dessa estratégia contestatória e discriminatória, podemos supor que haja a sugestão para as seguintes perguntas: Quem são os chicanos hoje? A condição de anonimato está cedendo lugar para a espacialidade historicista do presente em que o chicano tem voz?

Por outro lado, o relato ainda comenta que os Astecas do Norte compõem a única maior tribo ou nação Anishinabeg (indígenas) encontrada nos Estados Unidos na atualidade, que "alguns chamam a si mesmos chicanos, e se veem como o povo cujo verdadeiro lar é Aztlán, isto é, "[o sudoeste dos Estados Unidos]" ["Some call themselves Chicanos and see themselves as people whose true homeland is Aztlán [the U.S. Southwest]”.] (p. 23).

Ao traçar esses paralelos, a narrativa de Anzaldúa fomenta e concretiza um tipo de formação híbrida da qual ela se apropria para dar sentido à sua proposta de produção narrativo-literária. Não apenas isso: ela interpõe temas fazendo emergir, de antigos questionamentos, o discurso ameaçador que transforma e traduz a sociedade chicana como um todo. 
De todas essas "misturas", as realidades externas enfocadas por Anzaldúa significam o conhecimento sobre a Raza ao mesmo tempo que se aplicam à antiga questão das referencialidades históricas chicanas, transformando a cultura em histórias, mencionando a relevância do significado regional. Anzaldúa reconhece a necessidade de se manifestar sobre a tradição cultural do seu povo e produzir a possibilidade de criação de uma identidade cultural.

Em um momento em que os chicanos estão diante da possibilidade de terem uma voz direta e viva para expressarem os propósitos de suas lutas, qualquer tipo de narrativa, seja em prosa ou verso, música ou cinema, literatura ou historiografia, parece amparado por uma sólida moldura construindo a história desse povo. De acordo com Bhabha,

o povo é agora o próprio princípio de "reorganização dialética" e constrói sua cultura a partir do texto nacional traduzido para formas ocidentais modernas de tecnologia de informação, linguagem, vestimenta. O novo lugar de enunciação político e histórico transforma os significados da herança colonial nos signos liberatórios de um povo livre e do futuro. (1998, p. 68)

Nesse sentido, Anzaldúa se expressa pela solidão como sobrevivente da dor de se perceber descendente da "única" tribo Anishinabeg vivendo nos Estados Unidos, ou pelo fato de se descobrir em um "mundo" onde tudo parece ter a mesma aparência: homens, carros, ruas, prédios, casacos, caminhões, todos, dentro de um império hegemônico que a faz desejar o retorno a Aztlán, o antigo lar, perdido depois de tantas colonizações.

A desintegração étnica efetivou-se devido à soberania dos acontecimentos do passado, e a autora reflete esse estilhaçamento, com um tipo de voz forte e significativa, narrando a dor da sua coletividade, daqueles que fizeram da história uma forma presente de resistência, um registro conhecido como a realidade histórica do chicano, a fim de se compreender o horror de precisar se subjugar ao colonizador espanhol, e, mais tarde, ao colonizador do Norte, os Estados Unidos.

As histórias de vida são resgatadas junto com suas dores e intensidades subjetivadas feito um documento recuperado da barbárie incompreensível, barbárie tornada realidade 
histórica. Ao testemunho de Anzaldúa resta condensar as amarguras da destruição vivida em todos os tempos, e seguir registrando que o vento tocou a manga da camisa, que ela afundou os pés na areia e esteve na fronteira onde a terra e o mar se tocam [...]; cruzou a fronteira mexicana e esteve olhando o mar atacando a fronteira do Park Field com suas águas imensas [...]; também ouviu o choro do mar e respirou o ar; andou pelo buraco da cerca até o outro lado [...]; e, sob o céu de ferro, viu crianças mexicanas chutarem suas bolas de futebol e depois correrem, entrando nos Estados Unidos; viu as 1950 milhas da ferida aberta dividindo o povo, observou a cultura dividindo o povo, a cultura [...];dividindo-a, rachando-a ["Wind tugging at my sleeve / feet sinking into the sand / I stand at the edge where earth touches ocean [...]; Across the border in Mexico / Miro el mar atacar / la cerca en Border Field Park / con sus buchones de água [...]; Olgo el llorido del mar, el respiro del aire, [...]; Beneath the iron sky / Mexican children kick their soccer ball across, / run after it, entering the U.S. [...]; 1.950 mile-long open wound / dividing a pueblo, a culture / splits me splits me / me raja me raja”.] (p. 23-24).

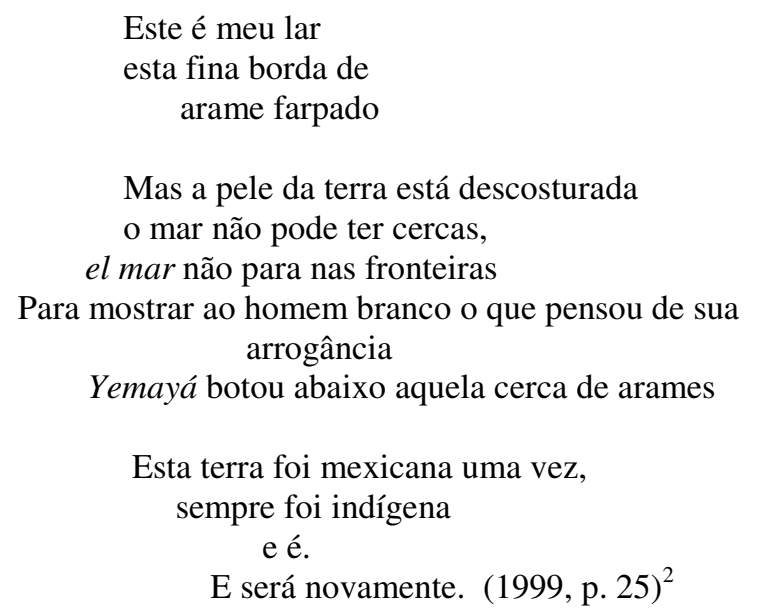

Desse lugar de onde fala o sujeito testemunhal, cabe recuperarmos a memória do povo para torná-la compreensível e, também, entendermos a gramática interna da ideologia chicana, seus poderes, e em quais esferas da vida sócio-cultural elas atuam, para 
compreendermos como memória e gramática se apossam da sua voz a fim de questionarem sobre as "diferenças" que tanto incomodam o povo que as subjugou.

Sendo assim, Anzaldúa parte da tensão bipolarizada de oferecer, sempre, dois limites ao mesmo tempo: aquele que se pode aceitar e o outro em que se questiona sobre as instabilidades.

$\mathrm{Na}$ verdade, existe a hipótese de essas diferenças assumirem o comando da variedade de figuras que performativizam o passado histórico do povo chicano para legitimá-lo como autêntica presença autobiográfica estruturando a objetividade. Ela pode universalizar seus pressupostos e, de forma onisciente, usar suas técnicas narrativas de maneira a realizar impactos por onde quer que volte seu olhar.

No nosso caso, seu olhar voltou-se para a prática de quebras de fronteiras determinando a condição própria de produzir sentido, uma vez que testemunha ter estado na fronteira onde a terra e o mar se tocam, e naquela borda transposta pelas crianças para se perceberem nos Estados Unidos.

Este contexto não ignora as dimensões sociais, históricas ou ideológicas do chicano, mas como aborda a questão das fronteiras, essa contextualidade deve ser considerada como o discurso daquele que se percebe desterritorializado. Ao revelar-nos esses movimentos, Anzaldúa faz nos perguntarmos o seguinte: para onde vai "aquele" que cruza fronteiras em um eterno movimento de ir-e-vir, sem encontrar nenhuma área neutra ou inexpressiva onde possa deitar suas raízes? Que inevitável erro foi cometido que "ele" não consegue fazer considerar suas reivindicações afirmando sua cultura e sua sociedade?

Aqui, como em todos os pontos presentes para a incorporação histórica chicana, a "fronteira" passa a representar a divisão entre Norte e Sul, entre um "terceiro" e um "primeiro" mundo. 
Como forma a ser introjetada, a fronteira tornou-se o tema decisivo e essencial para se discutir sobre a atual sociedade chicana: uma multiplicidade de individualizações, assim como de diferenças, culturas, espaços sociais, idiomáticos e da tradição, que se superpõem e se influenciam mutuamente.

Mais do que isso, não é de surpreender que hoje, a fronteira seja encarada como aquela linha divisória simbólica e existencial, marcada como a metáfora da bi- ou da transnacionalidade. Ao relacionar movimentos de chegadas e de partidas, a fronteira tem sido, de forma visível, vista por muitos como o inevitável laboratório experimental para os acontecimentos da pós-modernidade. Segundo Bhabha,

\begin{abstract}
a fronteira que assinala a individualidade da nação interrompe o tempo autogerador da produção nacional e desestabiliza o significado do povo como homogêneo. O problema não é simplesmente a "individualidade" da nação em oposição à alteridade de outras nações. Estamos diante da nação dividida no inteiro dela própria, articulando a heterogeneidade de sua população. A nação barrada Ela/Própria [It/Self], alienada de sua eterna autogeração, torna-se um espaço liminar de significação, que é marcado internamente pelos discursos de minorias, pelas histórias heterogêneas de povos em disputa, por autoridades antagônicas e por locais tensos de diferença cultural. (1998, p. 209-210)
\end{abstract}

Qualquer que seja a ideia para se pensar sobre a fronteira, temos de levar em conta as reações culturais dos chicanos para apregoarmos o nascimento de uma nova diferença, uma arquitetura devolvida à sua dimensão social com uma outra peculiaridade: a de que a "terra foi mexicana uma vez, sempre foi indígena, e é, e será novamente”.

Cabe salientar nessa passagem, o fato de os chicanos terem assumido uma identidade determinando a luta que travam para legitimar essa identidade. No processo de formação da "nova Raça”, aquilo que demonstram como reação ao hegemônico, é o resultado de eles preferirem continuar pertencendo à tradição mexicana, renovados pelos novos elementos e atitudes sócio-culturais necessários para viverem no contexto contemporâneo.

Assim, "identidade" e "diferença" não são temas que agrupam apenas categorias, mas abarcam, inclusive, processos de identificação e de diferenciação com o desejo de 
pertencimento, de ser parte de alguma comunidade. Nesse desejo, reside a paixão pela diferença, aquela que ainda nutre-os do parentesco pela tradição asteca.

Sendo assim, o sentimento de parentesco que os chicanos guardam em relação a esses indígenas comprova, por exemplo, o sentido que dão para as constantes "viagens" efetuadas entre fronteiras, entre os mundos, numa forma de explorar os espaços dessas mesmas diferenças, formadas a partir de misturas e divisões. De acordo com Reis,

em contato com o discurso lógico-racionalista, as culturas regionais se voltam para suas fontes locais, se impregnam delas, analisando essas formas culturais de acordo com suas formas tradicionais. De sua herança cultural retira sua sobrevivência, estabelecendo contato fecundo com as fontes vivas, que são inextinguíveis da invenção mítica nas sociedades, sobretudo rurais. (2005, p. 476)

Não é de nos surpreendermos, portanto, que uma das mais importantes contribuições da prática teórica de Anzaldúa seja a de articular, de modo simultâneo, uma política identitária a uma política de alianças, mostrando que esses parâmetros de agenciamento cultural, mesmo que de forma antitética, se reforçam e se interrompem produzindo diálogos e linguagens que se enriquecem com seus funcionamentos mútuos.

Ao direcionar-se linguisticamente por caminhos que a levam a tomar possíveis políticas de aliança articuladas a forças estratégicas de uma política de identidade, Anzaldúa propõe fincar "os pés na areia e permanecer na borda onde terra e mar se tocam" ["feet sinking into the sand / I stand at the edge where earth touches ocean"], numa referência às fronteiras que conectam uma linguagem a outra, mas que, às vezes, "em outros tempos e lugares", ocorre "uma quebra violenta" ["at other times and places a violent clash".] (p. 23). Ela nos ensina, dessa forma, que, para formar alianças, é necessário adquirir e lidar com estratégias flexíveis e transitórias ao mesmo tempo, além de conectar fronteiras históricas, todas ligadas a circunstâncias específicas.

Anzaldúa arquiteta alianças que incorporam certos valores e outros sentidos culturalmente aceitos como uma linguagem. Para ela, é necessário haver perspectivas que 
recusem qualquer reducionismo de subjetividades históricas a uma única categoria identitária fixa, desconectada de um contexto social e ideológico. Segundo Bhabha,

\begin{abstract}
A pergunta "O que deve ser feito?" tem de reconhecer a força da escrita, sua metaforicidade e seu discurso retórico, como matriz produtiva que define o "social" e o torna disponível como objetivo da e para a ação. A textualidade não é simplesmente uma expressão ideológica de segunda ordem ou um sintoma verbal de um sujeito político pré-dado. [...] o sujeito político [...] é um evento discursivo. (1998, p. 48)
\end{abstract}

A partir dessa equivalência, a tarefa de elucidar quem é o sujeito que fala no texto mostra que o espaço para recriação do sentido só pode ser dado caso a linguagem tenha a liberdade de inserir novos estilos de existência no discurso, ou, então, de ela lidar com aquele espaço que pressupõe a autonomia de poder dizer onde quer chegar com essas "falas". Se não existir luta possível entre liberdade de expressão e condições mínimas para seu exercício, somente um ambiente gerador de estratégias que transponham fronteiras será capaz de realizála.

O objetivo principal, hoje, parece ser o de explorar a crescente esfera da linguagem contemporânea previamente penetrada por sonhos de estado pleno de realizações. Sendo assim, na sua luta para efetivar "vozes" potentes contra tecnologias do poder, Anzaldúa afirma o seguinte:

\begin{abstract}
A fronteira entre México e Estados Unidos es una herida abierta onde o Terceiro Mundo se atrita contra o primeiro e sangra [...] Uma fronteira é uma linha divisória [...] um lugar vago e indeterminado criado pelo resíduo emocional de uma fronteira artificial [...] Os atravessados moram aqui [...] Os gringos do sudoeste dos Estados Unidos consideram os habitantes das fronteiras como transgressores, estrangeiros - tenham eles documento ou não, sejam chicanos, indígenas ou negros [...] Os únicos habitantes "legítimos" são aqueles no poder, os brancos, e aqueles que se aliam a eles. A tensão prendese aos habitantes como um vírus. Ambivalência e desassossego residem lá assim como a morte não é estranha. $(1999, \text { p. } 25-26)^{3}$
\end{abstract}

A encruzilhada em que nos lança Anzaldúa fica visível depois dessa declaração. Agora ela escreve mostrando a necessidade de precisar se manter numa perspectiva de alianças sem, contudo, abandonar a antiga noção histórico-social de cada instância de lutas. A autora envolve-se com as contradições sociais do chicano e demonstra que não se pode esperar uma 
política homogênea vivendo na fronteira, assim como não se pode esperar que surja da fronteira, um conteúdo que emancipe quem vive ali.

Pelo contrário, sua teoria pede que tenhamos o discernimento de perceber que cada instância é interseccionada e vivida de uma determinada maneira. Em outras palavras, ela mostra como a tensão se faz necessária entre ambas as forças de subjetividade, as de "lá" e as "daqui", para que as alianças se tornem possíveis entre os sujeitos intersticiais, mas que mantenham, também, com suas individualidades intactas, especificadas na articulação de se dizer sobre a tradição.

Com efeito, esse é um procedimento que deixa visível o paradoxo das próprias bases problematizando as contradições que não podem, ou não conseguem, ser desfeitas. Embora possam ser discutidas, as respostas absolutas e definitivas para completar essas questões não existem.

Anzaldúa reconhece que este é, talvez, apenas mais um modelo com o qual pretende dar continuidade à sua luta pelo reconhecimento da Raza chicana, que, segundo ela, sempre foi tão marginalizada, secundarizada. Sem nenhum privilégio, os chicanos sempre foram "tímidos" em suas vozes para contar sobre a variedade de caminhos que precisaram empreender desde a ancestralidade a fim de atravessar esse processo de negação.

Agora, as implicações ideológicas do texto de Anzaldúa são percebidas quando a autora informa sobre a migra, a patrulha da fronteira que persegue os chicanos, até mesmo quando trabalhavam no campo. Anzaldúa conta que a tia pedia para ela e os irmãos não correrem, pois agindo assim, a migra pensaria que eles seriam "do outro lado". Pedro, no entanto, sentiu muito medo, e "sem os papéis" de nascimento que identificassem quem era, foi levado com a marca da vergonha estampada no rosto e, depois, deportado para Guadalajara, de avião (p. 26). 
Suas palavras, mais uma vez, levam nosso pensamento a se desordenar, pois, em função do seu jeito de narrar, os "lugares" que nossos olhos devem percorrer para acompanhar esse vai-e-vem "fronteiriço", deixam uma abertura que nos remete, de modo constante, desse espaço para aquele, percorrendo limites indeterminados.

Nesse caso, ela lamenta a maneira de se viver na fronteira, pois vivendo nela, os mestiços estarão sempre vulneráveis, sozinhos e à mercê de um eterno jogo de perseguições que precisam enfrentar caso não queiram ser encontrados pela patrulha de fronteira que os devolve ao antigo pesadelo. Dessa capacidade de evitar a captura é que os mestiços tiram sua força para continuarem sobrevivendo, até mesmo sob a condição desesperadora de estarem condenados a uma inquietação psíquica por capturas.

As cenas descritas por Anzaldúa nesse depoimento podem ser consideradas, simbolicamente, como o núcleo do eterno conflito em não se deixarem dominar pela cultura do Norte. A topologia dessas superposições dão-nos a progressão da ideia de que os chicanos devem manter para continuarem sobrevivendo nas fronteiras, e dessa sobrevivência, poderem adaptar-se e transformar o espaço onde se encontram.

Dito de outro modo, a continuidade e descontinuidade dos fatos evidenciam a própria diferença como configuração de um processo de interação contínuo, em que é necessário perceber o espaço intersticial como aquele lugar de eterna migração.

Ao ser levado, Pedro metaforiza o mosaico que tem sido construído para elencar as silenciadas vozes dos colonizados, a ênfase que se tem dado às subjetividades excluídas. Ele é deixado em Guadalajara e por isso, precisou "andar" todo o caminho de volta até o Vale. "Levaram o pobre sem um centavo. Ele veio andando desde Guadalajara." ["Se lo llevaron sin un centavo al pobre. Se vino andando desde Guadalajara”.] (p. 26).

Dessa preocupação com a "figura de Pedro" a autora visa a representação do funcionamento de como um discurso testemunhal encara o modo de as identidades individuais 
e coletivas precisarem se alicerçar e se movimentar na travessia dos espaços intersticiais. Ambos os limites, o de lá e o daqui, estabelecem uma linha transversal que atravessa tanto segmentos estanques da sociedade, quanto permite novas articulações entre o falar e a prática.

As questões de subalternidade são tratadas por Anzaldúa ocupando um espaço central cuja relação intrínseca com a condição de se viver nas fronteiras é visível. Ela não se cansa de pontuar as dificuldades enfrentadas nesses espaços, vendo todo o povo chicano ser silenciado pelo sujeito hegemônico do Norte. O conhecimento sobre a exclusão dos chicanos permite que ela reconheça a força de seu discurso para intervir com sua "voz" e revelar a diferença entre "eles" e "nós".

Baseando sua teoria na apropriação desse Outro, Anzaldúa expõe o problema tornando-o próprio, ou seja, ela absorve aquela proposição para tornar-se um sujeito plural. Penna apresenta essa reflexão da seguinte forma: "O outro em mim ou eu no outro - eu falo pelo povo ou o povo fala através de mim - constituem processos reversíveis e complementares, baseados no intercâmbio e absoluta substituibilidade metafórica entre povo e eu" (2003, p. 317).

Ao desenvolver, pela linguagem, o processo de construção da (in)dependência sóciocultural chicana, a autora dá início a uma condição de resistência às hegemonias estrangeiras e incorpora novos movimentos sociais chicanos para dentro de seu contexto literário. O que a torna distanciada do cânone é sua presença no híbrido, nesse espaço perturbador autorizando o entremeio do "aqui" (nacional) com o "lá" (estrangeiro); entre prosa e verso "misturados" em uma mesma contextualidade, entre, enfim, formas de alteridade cultural.

É nessa caminhada que, como sujeito testemunhal, ela chega quase a "despersonalizarse" por completo para o testemunho servir de veículo de análise da coletividade e deslocar o papel da ficção a um segundo plano, para em seu lugar, fazer surgir o sujeito gestor das articulações entre os dois "mundos": o do outro e o meu. Segundo Bhabha, 
Nenhuma cultura é jamais unitária em si mesma, nem simplesmente dualista na relação do Eu com o Outro. Não é devido a alguma panacéia humanista que, acima das culturas individuais, todos pertencemos à cultura da humanidade; tampouco é devido a um relativismo ético que sugere que, em nossa capacidade cultural de falar sobre os outros e de julgá-los, nós necessariamente "nos colocamos na posição deles", em um tipo de relativismo da distância sobre o qual Bernard Williams tanto escreveu. A razão pela qual um texto ou sistema de significados culturais não pode ser auto-suficiente é que o ato de enunciação - o lugar do enunciado - é atravessado pela différance da escrita. (1998, p. 65)

O essencial, portanto, consiste em Anzaldúa apresentar o hibridismo que sua releitura histórica empreende para, assim, definir um outro lugar de expressão que oficialize a mistura de autonomias tão relativas. Agindo desse modo, a autora reconhece que a "primeira cultura" vive em cada um daqueles que, de uma forma ou de outra, cruzam a fronteira para os Estados Unidos. Sua postura reivindica que cada um dos "irmãos" se auto-defina não somente como gênero impuro, mas que se identifique, também, como a "nova Raça”, o "novo povo", surgido dos questionamentos político/culturais e das identidades como políticas. Para enfrentar os conflitos surgidos desses confrontos, torna-se necessário o reconhecimento de si mesmo e do Outro para identificarmos que estamos presos na mesma existência.

É essencial que pensemos, agora, sobre uma outra relativização que Anzaldúa nos coloca. O primeiro sentido de suas visões acerca do povo chicano é descrever como nação (guerreira) essa nova conjuntura populacional. Marcada por redefinições, o povo emerge das novas políticas nacionais tentando resolver os problemas sobre exclusão ou inclusão dos desterritorializados. Ao mesmo tempo, há negociações e embates necessários para solucionar a nova identidade da Raça, nessa nova situação de transnacionalidade, para que, assim, possa ser mantida.

Os espaços foram redefinidos e não só se pressupõe que o espaço chicano tenha se reconfigurado como política identitária, mas que se apresenta, inclusive, como forma de dignidade humana. Na figurativização de Pedro que regressa para "seu" antigo espaço, mesmo estando "sem um centavo", encontra-se a contemplação para que se resolva questões sobre a hegemonia. 
Parece que a questão de possuir uma identidade nacional chicana transformou-se na condição de empreendimento de luta por uma identidade racial. Isto é, se os chicanos se veem como uma nação sem fronteiras, indo e vindo sem saber a que país pertencem, isso lhes permite a existência de um "espaço" como aquele "entrelugar" que passa a se manter dentro e na borda de outros limites legais concedidos por Estados-nações. E, certamente, ao conceberem a identidade chicana com base na "nova raça", naquela "misturada" ao antigo sangue, é indicativo de que o povo crie uma ideologia baseada em um Estado-nação transnacional. De outra forma, como enfrentariam o efeito de incerteza identitária que aflige a cada um?

Assim, é pelo fato de irem para além do sangue e da raça que os chicanos agem de forma coletiva, feito uma espécie de evocação da memória. Esse processo faz, a todo momento, surgir o princípio de redescoberta do passado, daquela imagem mutilada em consequência de tantas conquistas por parte do colonizador estrangeiro, para que possam, então, se apropriar da autoridade da fala denunciando essa mesma violência.

Tanto de um modo como de outro, a reconstrução imagética vem do trabalho de Anzaldúa explorar e expor a vida de seus ancestrais, metamorfoseada pela sua linguagem, por meio da qual, eles se deram a conhecer. Ela narra que os primeiros habitantes das Américas migraram pelo Estreito de Bering, e que "A mais velha evidência do ser humano nos Estados Unidos - os ancestrais indígenas dos chicanos - foi encontrada no Texas há cerca de 35.000 anos A.C." ["The oldest evidence of humankind in the U.S. - the Chicanos' ancient Indian ancestors - was found in Texas and has been dated to 35000 B.C.’] (p. 26).

Essas tantas histórias brotam densas e pesadas da memória da autora e elas nos atingem feito um discurso onírico reinterpretado por sua literatura, sob a forma de testemunho. Anzaldúa tem "vivido" essas experiências a partir do momento em que se disponibilizou a pesquisar e a reconstruir considerações sobre a formação da Raza chicana. 
Ela soube captar quase a totalidade das manifestações culturais de sua época, do passado, e as expõe, agora, por meio de singularidades, a condição de ultrapassar limites que o povo tem enfrentado. Além do mais, ela mostra suas reflexões sobre as transformações sofridas pela etnia, sobretudo as manifestações mítico-religiosas. Segundo a autora,

Huitzilopochtli, o Deus da Guerra, guiou-os ao lugar (que mais tarde se tornou a cidade do México) onde uma águia com uma serpente debatendo-se em seu bico, empoleirou-se em um cacto. A águia simboliza o espírito (como o sol, o pai); a serpente simboliza a alma (como a terra, a mãe). Juntos eles simbolizam a luta entre o masculino/espírito/celestial e o feminino/submundo/terreno. O sacrifício simbólico da serpente aos poderes masculinos "superiores" indica que a ordem patriarcal já dominava a ordem feminina matriarcal desde a América pré-Colombiana. $(1999, \text { p. } 27)^{4}$

Com o surgimento dessas lembranças evidenciando a presença da terra materna como o lugar edênico que deu origem aos astecas, parece não haver mais dúvidas de que a certeza possibilitando a volta a esse Éden, à essa terra, não existe mais. Assim como para o bebê, "a voz da mãe é a voz da música" (CHNAIDERMAN, 1989, p. 93), para os chicanos, a perda da voz do lugar materno, Aztlán, deu origem a um nascimento vibratório, sonoro, de uma voz que, a todo momento, é impedida de se manifestar. Como o autista que fica isolado do seu meio, impedido de fazer trocas para continuar vivendo, assim também os chicanos sentem-se isolados, marginalizados, sobreviventes apenas de uma memória gloriosa. É como se eles estivessem dominados por um elemento paranoico do poder estrangeiro sem conseguir projeção para o futuro.

Por mais que queiram tornar-se eficazes, chamando por um lugar ao sol, essa interdição aos chicanos só poderá ser extinta quando a "voz materna" voltar a se pronunciar e ser ouvida. Na tentativa de resolver a questão, eles têm despendido um tempo de mais de três séculos, buscando formas de romper com a repressão que lhes tem sido imposta. Ainda de acordo com Chnaiderman (1989), o espaço sonoro é o primeiro espaço psíquico e, por meio de suas manifestações, é possível intervir e organizar um conjunto de fenômenos sonoros a fim de se recuperar o universo sonoro perdido, desconectado da voz materna. 
Toda essa problemática ganha sentido quando os sons primitivos da ancestralidade chicana puderem ter seu espaço e puderem se manter não como jugo de uma hegemonia estrangeira, mas como ruptura para se resgatar a própria palavra, ou seja, como alteridade que, ao invés de ficar relegada a um simples lamento, possa romper os laços do rebaixamento e tornar-se o objeto central dessa correspondência. De acordo com Bhabha,

\begin{abstract}
As culturas vêm a ser representadas em virtude dos processos de iteração e tradução através dos quais seus significados são endereçados de forma bastante vicária a - por meio de - um Outro. Isto apaga qualquer reivindicação essencialista de uma autenticidade ou pureza inerente de culturas que, quando inscritas no signo naturalístico da consciência simbólica, freqüentemente se tornam argumentos políticos a favor da hierarquia e ascendência de culturas poderosas. É nesse intervalo híbrido, em que não há distinção, que o sujeito colonial tem lugar [...]. (1998, p. 95)
\end{abstract}

$\mathrm{Na}$ verdade, essa ruptura já teve início quando começou a ser enfocada por Anzaldúa como lei que comanda o desejo em busca de um significado central para se pensar a cultura chicana. Uma vez determinada como signo que marca a presença histórica do povo, a cultura tem significado não apenas na luta empreendida para resgatar a terra perdida, mas na resposta formando uma outra fala, uma outra sintaxe, ela própria articulada intra e interterritorialmente.

Sendo assim, tudo isso prepara o cenário para visualizarmos a imagem que vem com o próximo testemunho de Anzaldúa. O reflexo espelhando essa intertextualidade reforça a temática da mensagem que conta sobre o mestiço, aquele que teve início desde o século XVI com a invasão do México pelos espanhóis, comandados por Hernán Cortés. Ela narra que, “Em 1521 nasceu uma nova raça, o mestiço, o mexicano, (povo misturando sangue indígena e espanhol), uma raça que nunca tinha existido antes. Chicanos, mexicanos-americanizados, são a descendência daqueles primeiros habitantes" [“Em 1521 nació uma nueva raza, El mestizo, el mexicano (people of mixed Indian an Spanish blood), a race that had never existed before. Chicanos, Mexican-Americans, are the offspring of those first matings”.]. Então, depois, 
Para os indígenas, isso constituiu um retorno ao lugar da origem, Aztlán, que promoveu os chicanos original e secundariamente como os indígenas do sudoeste. Índios e mestiços do México Central casaram-se com índios da América do Norte. O contínuo matrimônio entre indígenas mexicanos, americanos e os espanhóis formou uma mestiçagem ainda maior. (1999, p. 27)

Muito se tem falado sobre os campos de encontro de um povo com outro, resultando uma outra cadeia. A variedade de textos metaficcionalizando o desenvolvimento desses grupos, recapitula e comenta sobre o destino de seus antepassados que, de uma maneira ou outra, encenam o que se pode configurar como a mistura resultante da história e do processo de desenvolvimento das etnias.

A ideia defendida por Anzaldúa não deixa de ser aquela que se tornou impregnada pelos espaços que estão continuamente contingenciando e retraçando as fronteiras para além de um simples eco, ao mesmo tempo que expõem os limites da diferença, sobretudo os diferenciadores de classe, gênero ou raça.

Em sua genérica mistura de histórias apresentando "a verdade" chicana de misturas étnicas, percebemos o entrelaçamento do factual com o fictício em que, para além da diferença entre um e outro, encontra-se o intervalo a ser substancializado por uma forma de futuro em que ambos, factual e fictício, se mesclam para cantar a Raza. Lá, onde o espaço colonial se encontra entremeado de espaços da diferença, está a autoridade de emergência do "novo" e do "Outro". Ainda de acordo com Bhabha,

\begin{abstract}
Mais uma vez, é o desejo de reconhecimento, "de outro lugar e de outra coisa", que leva a experiência da história além da hipótese instrumental. Mais uma vez, é o espaço da intervenção que emerge nos interstícios culturais que introduz a invenção criativa dentro da existência. E, uma última vez, há um retorno à encenação da identidade como iteração, a re-criação do eu no mundo da viagem, o reestabelecimento da comunidade fronteiriça da migração. O desejo de reconhecimento da presença cultural como "atividade negadora" de Fanon afina-se com minha ruptura da barreira do tempo de um "presente" culturalmente conluiado. (1998, p. 29)
\end{abstract}

A melhor maneira de Anzaldúa fazer uma intertextualidade entre tantas diferenças, é o fato de que, para ela, o Outro é um intervalo intersticial, um tipo de futuro que tem emergido do "entremeio ” das histórias do passado com as necessidades de apresentação do povo 
chicano, no presente. A mestiçagem sobre a qual se refere a autora, faz supor aquela sem limites, a que desloca elementos, para que se multipliquem e se entrecruzem pelas mais diferentes vias, os diferentes resultados imprevisíveis.

A mestiçagem referida por Anzaldúa não seria mais aquela carregada da maldição de "ser" chicano, de ter "sido" dizimado, mas a mestiçagem encarada como fonte de possíveis riquezas e disponibilidades, resultantes do esforço por sobreviver. Ao mesmo tempo que lamentam a perda de Aztlán, os chicanos já se encontram misturados a outras verdades que os encorajam a privilegiar os resultados, obtidos com a força da voz ao invés dos lamentos da perda.

A importância de tais conquistas fica evidente quando, mesmo sendo encarados como os despossuídos, que têm sofrido com certos tipos de preconceitos e com a exploração, eles se identificam com as comunidades indígenas das quais descendem. Embora tenham sido colonizados em sua própria terra, eles dominam uma variedade de espaços internos e externos que os faz ser a nova identidade. A reapropriação desta personalidade histórica passa a representar o esforço de Anzaldúa para que, do local de fala da cultura, ela possa alinhavar essas vozes mestiças às experiências vividas. Mais do que tudo, o "estranho" já reconhece suas especificidades e sua influência sobre outras ideias.

Assim, o confronto histórico entre o eu e o outro fica marcado, mais uma vez, pela reorganização dos espaços a partir de uma nova perspectiva, geradora de novos processos da prática discursiva. O pensamento pós-colonial reaviva a dicotomia centro/periferia e, dessa forma, Anzaldúa se vê autorizada a recolocar as discussões em torno desse lugar de enunciação, dando privilégio à temática das diferenças coloniais. De acordo com Mignolo,

a literatura e as teorias pós-coloniais estão construindo um novo conceito de razão como loci diferenciais de enunciação. O que significa "diferencial"? Diferencial significa aqui um deslocamento do conceito e da prática das noções de conhecimento, ciência, teoria e compreensão articuladas no decorrer do período moderno. (2003, p. 167) 
Se, como Mignolo afirma, o locus de enunciação do centro cedeu lugar a um locus de enunciação diferencial, ou seja, àquele da periferia, Anzaldúa pôde e soube se articular livremente por entre os nichos da razão pós-subalterna e, de dentro dessa articulação, destacar e explorar a política dos locais enunciativos dados, todos, pela atuação humana da conscientização. Ela se transforma naquele outro, naquele que deixou de sentir-se colono, identifica-se transitando no espaço alheio e nessa distância, forma sua figura de alteridade.

A história da diáspora chicana tem sido revista por Anzaldúa não apenas do ponto de vista da libertação dos oprimidos, mas a partir da autolibertação colonizador-colonizado que os têm feito caminhar em direção a um realinhamento da polaridade "nós-eles". A marca dessa indeterminação continua e talvez nunca cesse, mas já é uma conquista o fato de os chicanos terem se transculturalizado e apresentarem, hoje, uma pluralidade social, linguística e econômica, presentes na expressividade do passado e do presente da cultura, rearticulada entre anglos, mexicanos, americanos e chicanos. Bhabha nos auxilia na compreensão deste hibridismo,

o reconhecimento teórico do espaço-cisão da enunciação é capaz de abrir o caminho à conceitualização de uma cultura internacional, baseada não no exotismo do multiculturalismo ou na diversidade de culturas, mas na inscrição e articulação do hibridismo da cultura. Para esse fim deveríamos lembrar que é o "inter" - o fio cortante da tradução e da negociação, o entre-lugar - que carrega o fardo do significado da cultura. Ele permite que se comecem a vislumbrar as histórias nacionais, antinacionalistas, do "povo". E, ao explorar esse Terceiro Espaço, temos a possibilidade de evitar a política da polaridade e emergir como os outros de nós mesmos. (1998, p. 69)

É dessa forma que o objeto híbrido dessa identidade chicana não se apresenta como simples representação do "real", e sim, como prática cotidiana que conscientiza e politiza os indivíduos, mesmo os ainda rejeitados e anônimos, distanciados da ideologia de integrarem a validação dessa prática identitária. Ao confrontarem diferenças, fazerem convergir "eu/outro" no mesmo espaço, é quase impossível não reivindicarem uma origem para si mesmos e para esse outro. 
Ao reforçar o passado cultural comum a todos em detrimento do colonialismo estrangeiro, Anzaldúa tece estratégias de sobrevivência que passa a seus "irmãos" como forma de "assimilação" da cultura estrangeira, transculturalizando-se todos, mas que, ao mesmo tempo, resistem a essas mesmas referências assimiladas como manifestação de um sentido de vergonha diante da perda da terra. Neste trabalho, envolvem-se em conservar a tradição e, também, precisam alternar a própria cultura com a do "outro".

"Vivenciando" essa noção, Anzaldúa conta que em 1800 teve início "o desterro / a terra perdida" ["El destierro / The Lost Land"], para os chicanos (p.28). Os anglos invadiram o território que hoje é o Texas e cometeram atrocidades. Os mexicanos que viviam ali, da noite para o dia se tornaram estrangeiros na própria terra. "Em 1846 os Estados Unidos incitaram o México para a guerra. As tropas dos Estados Unidos invadiram e ocuparam o México forçando-o a desistir de quase metade da nação, o que agora é o Texas, o Novo México, Arizona, Colorado e Califórnia" ["In 1846, the U.S. incited Mexico to war. U.S. troops invaded Mexico, forcing her to give up almost half of her nation, what is now Texas, New Mexico, Arizona, Colorado and California”.] (p. 29). E assim, dirigindo nossa atenção, a autora continua narrando que uma fronteira dividindo o México dos Estados Unidos foi consolidada a 2 de fevereiro de 1848, com a assinatura do Tratado Guadalupe-Hidalgo. "Com o desterro e o exílio fomos desunidos, cortados, esmagados - fomos arrancados de nossas raízes, truncados, estripados, despossuídos, e separados da nossa identidade e de nossa história” ["Com el destierro y el exílio fuimos desuñados, destroncados, destripados - we were jerked out by the roots, truncated, disemboweled, dispossessed, and separated from our identity and our history”.] (p. 29-30).

O caráter impactante dessa afirmação é sintomático, uma vez que, mesmo singularizando um âmbito de individualidades consideradas subalternas, Anzaldúa prioriza o argumento de mostrar um modelo aditivo de opressões que os mestiços têm sofrido desde 
sempre. Ao fazer ecoar todos aqueles acontecimentos, ela se posiciona para entrar em confronto com o mundo colonizado, delineando questões sobre identidade. Ao entrar em contato com essa série de lugares contraditórios, é como se ela continuasse perguntando o que quer o colonizador, o que ele pretende privilegiar depois da conquista, e como os chicanos serão reconhecidos e identificados nessa representatividade irreconhecível.

Dessa maneira, consciente de que precisa levar sua postura adiante, Anzaldúa interroga-se sobre as diferentes formas de resistência cultural para poder incorporar a dinâmica em cada luta empreendida, ao invés de ignorá-la. Ainda nesse enquadramento, parece que ouvimos a "voz" da autora afirmando que nada pode ser eliminado: nem o bom, nem o ruim, sequer o feio, caso se queira fazer parte do instante inscrito no desejo escópico, ou seja, naquele momento em que "olho" e "sou olhado".

Dessa relação nasce o espaço em que "ver" e "ser visto" dimensionam a posição enunciatória do sujeito discursivo. Para Bhabha, "O que se interroga não é simplesmente a imagem da pessoa, mas o lugar discursivo e disciplinar de onde as questões de identidade são estratégica e institucionalmente colocadas" (1998, p. 81).

A virtualidade que salta desse sentido, portanto, é a de que o Outro não pode ser concebido apenas como objeto de estudo, mas deve, também, ser encarado como reflexão sobre os problemas de identidade.

Talvez, o ganho mais importante de toda essa problemática seja o direito a ter direitos. De uma forma ou de outra, os chicanos não se reconheciam inseridos nessa regra, tanto que Anzaldúa relata que precisou se "rebelar" e deixar o Vale onde morava para seguir seu destino rumo às letras (1999, p. 38). Agora, os chicanos têm emergido com uma "linguagem" própria reivindicando direitos e estabelecendo identidades para a etnia. Eles inauguraram a história da Raza. 
É por ter essa natureza revolucionária e transgressora que Anzaldúa nunca deixou de ser olhada como aquela força criativa capaz de abalar e, ao mesmo tempo, desestabilizar todas as formações culturais constituídas em bases hegemônicas. Centrada em práticas culturais que considera uma evolução para a alteridade, Anzaldúa e seu discurso são inevitáveis para transformar o estabelecido, uma parte capaz de se inserir em todos aqueles trajetos que surgem e vão mudando a história ao longo do tempo e do espaço.

As implicações políticas de seu discurso para defender o povo são objeto de uma luta sem fim que, para todos os lados que se volta, perfila posições ambivalentes, abertas a todo tipo de defesas ou de acusações.

Assumindo essa posição, Anzaldúa conforma a essência do sentido em testemunhar e descrever como grupos de vigilantes ingleses executaram rancheiros mexicanos e apossaramse de suas terras; como aquele mesmo exército "trouxe 20.000 homens para pôr um fim ao movimento de protesto social no Sul do Texas", e como a sua própria mãe perdeu as terras. ["brought in 20.000 army troops to put an end to the social protest movement in South Texas"] (p. 30). Segundo Anzaldúa, sua mãe "Não falava inglês, não soube pedir um tempo até juntar o dinheiro" para saldar a dívida. ["No hablaba inglés she didn’t know how to ask for time to raise the money.’] (p. 30). Depois, quando a discriminação se transformou em algo insustentável, o povo precisou, mais uma vez, mudar a realidade e empreender " $O$ cruzar do molhado/ O cruzar ilegal” [“El cruzar del mojado / Illegal Crossing”.] (p. 31).

Ao colocar a emergência desses acontecimentos, Anzaldúa revela que uma outra experiência fronteiriça está relacionada a uma política do pânico. Precisando fugir do lugar para não serem mortos ou porque lhes foi tirado o rancho e a terra, a referência étnica do chicano é deslocada e virada do avesso. Os acontecimentos seguem uma sequência desestruturada e de tal forma desconectada, que aos chicanos não fica outra pergunta a não ser aquela já experienciada: a que lugar eu pertenço? 
Sentindo-se invadidos, os atravessados estão incessantemente cruzando a fronteira em uma tentativa de fazer alianças para sentirem-se, pelo menos, incluídos nessa ou naquela comunidade. Talvez essa seria a forma de posicionarem-se como menos indecisos, menos aterrorizados. Atuando na duplicidade de pertencer tanto àquele espaço quanto a esse outro, os chicanos tentam não desaparecer dessa infraestrutura espacializada entre "eu" e o "outro".

O pânico pode ser considerado um movimento de tamanha transformação que, para além da violência do dualismo de "ser" ou isso ou aquilo, instala-se a destruição da ordem social. Isto é, de uma forma ou de outra, com o registro das incertezas cravado na identidade de cada um dos chicanos, o pânico se perpetua, e não consegue registrar certeza alguma.

Dessa forma, a ordenação sócio-cultural do entremeio surge novamente e a fronteira das idas e vindas se presentifica de maneira física, psicológica ou abstrata, levando-os a encarar o fato como uma herança que os torna alheios, um animal que jamais conseguirá determinar uma sequência de acontecimentos linear para sua vida. Afinal, o chicano não precisará sair correndo de suas terras novamente? Qual a segurança de que essas terras não serão novamente confiscadas?

O resultado para esse tipo de questionamento é o prenúncio de uma rebelião travada interiormente - o chicano nunca tem respostas concretas para suas dúvidas, ou sobre suas identidades - e, de maneira externalizada, ele adere à ideia de que precisa travar uma eterna luta político-social que o faça ter uma voz para legitimar seus direitos. Para reestruturar sua confiança como cidadão, o chicano tem de experimentar este contexto pós-colonial, de atuar naquelas instâncias interativas que o faz ir-e-vir como se fosse um eterno permanecer entre "aquil" e "lá".

Além do mais, outros fatos, sérios, ligados às questões da pós-colonialidade estão conectados à economia mundial pela qual os chicanos também são atingidos. Encaixada em 
um período em que o capitalismo se organizou com o pensamento neoliberal, o que marca a economia atual é a completa desestruturação e desmantelamento do Estado.

Anzaldúa deixa claro em seu texto que, durante "a crise", milhões de trabalhadores perderam seus empregos em função da desestatização de empresas que se tornaram privadas em função do poder cada vez mais forte do livre-comércio. "Não tem trabalho", exclama ela, intensionando argumentar que o Estado vem se submetendo mais e mais aos agentes do livrecomércio, às imensas corporações transnacionais, tais como as citadas "American Motors, IT\&T, e Du Pont", que possuem fábricas chamadas maquiladoras. Nelas trabalhavam um quarto da população mexicana, a maioria mulheres jovens que, por isso, deixavam os filhos vagando pelas ruas. Em consequência disso, as crianças são "adotadas" pelas "cholo gangs" (1999, p. 32)

Esse olhar introspectivo da autora também nos dá a conhecer que, pelo fato de os chicanos estarem vivendo "a crise", é nítido o fato de o poder político estar sendo subjugado ao poder econômico-financeiro, pois, com a introdução do livre-comércio nas nações de economias extremamente desiguais como é o caso do México, as consequências prejudiciais envolvendo os trabalhadores são imensas. O peso mexicano foi desvalorizado em relação ao dólar, o México passou a depender dos Estados Unidos e metade da população mexicana estava desempregada (p. 32).

Talvez esta seja a perversidade sócio-econômica radical que tenha caído sobre os mexicanos. Mesmo tendo um "fluxo livre" de mercadorias, investimentos, capitais, não existe a livre circulação de pessoas, pois, uma vez desempregados, não lhes é permitida a livre circulação de mão de obra. Visando a diminuição dos gastos, as empresas pagam salários menores, procuram pelo trabalhador menos organizado enquanto classe e, desse descontrole, resulta o caos social. 
Só lhes resta "atravessar" para o Norte. Retornar ao lar que já lhes pertenceu uma vez, e desfrutar, talvez, de uma vitória futura. Sobre esse tópico Anzaldúa afirma o seguinte: “Temos uma tradição de migrar, uma tradição de longas caminhadas. Hoje estamos testemunhando a migração dos povos mexicanos, a odisséia do retorno ao mitológico/histórico Aztlán. Desta vez, o trajeto é do Sul para o Norte" ["We have a tradition of migration, a tradition of long walks. Today we are witnessing la migración de los pueblos mexicanos, the return odyssey to the historical/mythological Aztlán. This time, the traffic is from south to north".] (1999, p. 33).

Ao abordar questões desse porte, parece que o sujeito testemunhal diante do desejo de permanecer em silêncio ou daquele de articular-se por meio de uma expressão artística, vence o segundo. Anzaldúa expressa o horror inerente que é o de precisar "sair" do seu lar para não experimentar as más consequências que levaram do mundo das ruínas. Mesmo diante de um acontecimento sem plano ou sem vontade, mesmo diante do pior tipo de desassossego, em não visualizar uma separação de si mesmo, parece que ela nos diz ser melhor oscilar entre o medo e a esperança, do que duvidar das possibilidades do futuro e permanecer sem ação.

Longe de pensarmos que os chicanos desistiram de suas lutas pelo fato de serem perseguidos pela Patrulha da Fronteira, está o registro de "os molhados" atravessarem o "rio Grande" invocando a proteção da "Virgem de Guadalupe em seus lábios: $A i$, minha virgenzinha morena, minha mãezinha, dá-me tua bênção" ["with a prayer to Virgen de Guadalupe on their lips: ay virgencita morena, mí madrecita, dame tu bendición.”] (1999, p. $33)$.

Sendo assim, essa é a interrogação para o momento: como explicar tamanha luta por parte dos chicanos para enfrentar o poder político do outro? Em que consiste essa reação? Talvez seja a reação ao sentimento de perda daquele objeto que lhes foi arrancado do corpo sem nem mesmo terem tido tempo para encontrar uma outra saída. Aquele objeto que estava 
exterior a cada um deles, mas que, no entanto, era o que tinham de mais central e íntimo: o lar, o desejo inconsciente de pertencimento a esse lugar.

Diante da dor da perda, os chicanos vivem a fantasia de que do outro lado, no Norte, está a possibilidade de encontrarem algo melhor para acalmar a dor. E, então, nitidamente, eles continuam a busca de preenchimento do vazio, deixado pelo desejo de sentirem-se em casa.

Desse local doloroso, dessa dor psíquica provêm os múltiplos caminhos para que se busque a "voz" para reviver a dor da perda do objeto amado. Segundo Nasio, "O que dói, não é perder o ser amado, mas continuar a amá-lo mais do que nunca, mesmo sabendo o irremediavelmente perdido. Amor e saber se separam" (1997, p. 30).

O drama vivido pelos mexicanos não termina aí. Anzaldúa acrescenta que a mulher mexicana "está especialmente em risco". Ela pode ser contrabandeada pelo coyote, trabalhar como doméstica nas casas norte-americanas, ou nos hotéis, tanto quanto ser estuprada ou vendida para prostituição, e até, ficar enferma dos nervos e deprimida. Anzaldúa também narra o seguinte:

Ela não pode ir para casa. Ela vendeu sua casa, seus móveis, tomou dinheiro emprestado dos amigos para pagar o coyote que lhe cobra quatro ou cinco mil dólares para contrabandeá-la para Chicago. Ela pode trabalhar como empregada para o branco, o chicano ou o Latino pela bagatela de $\$ 15$ dólares a semana. $(1999, \text { p. } 34)^{6}$

A insistência que Anzaldúa dá à corporeidade do sofrimento fica, de novo, evidente com este testemunho. De seu ponto de vista, ela deixa claro que a mulher mexicana tem sido exposta a uma situação de clausura sócio-cultural que a transforma, quase, em um ser destituído de qualidades próprias. Se não fosse por sua condição de ser "corajosa", "renovada" para a luta, a "diferente", talvez a mulher mexicana permanecesse eternamente na condição de solitária, aquela que frente à cultura e à natureza, é identificada como um simples prolongamento do macho. Seu desejo insatisfeito de permanecer subjugada parece vincular-se 
àquela angústia do nascimento, ou seja, a mulher mexicana parece estar fora daquela condição produtora de vida.

Mas, a partir do momento que ela se reconhece como ser específico, culturalmente à frente de uma simples função feminina de ser paciente, tolerante, materna, ela sinaliza ter encontrado sua identidade como mulher. Assim, ela é aquela que reage ao temor de encontrar "lá do outro lado", o estranhamento de experimentar a vida como coisa ruim. A mulher mexicana se posiciona na passagem de unir os fragmentos de fora de si mesma e reúne forças vivas e caóticas rumo a uma ordem interior.

Este extenuante caminhar da mulher mexicana aproxima-a da condição de precisar reconstituir a forma permanente, a sua própria imagem, ou seja, de ela precisar ter a sensação de se transformar no "diferente", naquela que procura reparar o interior invadido e dilacerado pelo agressor.

Por onde deveria passar a mulher mexicana? Seria o momento de ela aceitar a intimidade culpada e reinventar o objeto do desejo, perdido em cada situação de desconforto?

Parece que, para esse tipo de mulher que tenta abrir-se para mudanças, que tenta reintegrar-se nesse e naquele espaço, existem sempre duas saídas, uma positiva e a outra negativa, uma no tempo e outra no espaço, uma no ser e outra no não-ser, numa perpétua (re)integração afetivo-social.

A (re)colocação da mulher em suas participações de produção aumenta a possibilidade de ela executar a manifestação de uma outra coisa que a complementa e, ao mesmo tempo, faça-a acontecer como conteúdo que dá vida ao presumivelmente não material. Afinal, reconhecendo-se como princípio de conservação de representações do feminino, a mulher mexicana desencadeia a abertura para os diferentes níveis de se atingir o invisível. "Deixando o conforto da família para se aventurar em terrenos desconhecidos e possivelmente perigosos", - mais uma vez, ela "atravessa" as fronteiras para, de maneira persistente, 
conservar em si, os vestígios das transformações e das diferenças ["she leaves the familiar and

safe homeland to venture into unknown and possibly dangerous terrain".] (1999, p. 35).

\section{NOTAS}

1- "El otro México que acá hemos construído / el espacio es lo que ha sido / territorio nacional./ Este es el esfuerzo de todos nuestros hermanos / y latinoamericanos que han sabido / progressar". Los Tigres del Norte (apud ANZALDÚA, 1999, p.23)

2- "This is my home / this thin edge of / barbwire / But the skin of the earth is seamless. / The sea cannot be fenced, / el mar does not stop at borders. / To show the white man what she thought of his / arrogance, / Yemayá blew that wire fence down. / This land was Mexican once, / was Indian always / and is / And will be again". (ANZALDÚA, 1999, p. 25)

3- "The U.S.- Mexican border es una herida abierta where the Third World grates against the first and bleeds [...] A border is a dividing line [...] a vague and undetermined place created by the emotional residue of an unnatural boundary [...] Los atravessados live here [...] Gringos in the U.S. Southwest consider the inhabitants of the borderlands transgressors, aliens - whether they possess documents or not, whether they're Chicanos, Indians or Blacks [...] The only "legitimate" inhabitants are those in power, the whites and those who align themselves with whites. Tension grips the inhabitants of the borderlands like a virus. Ambivalence and unrest reside there and death is no stranger". (ANZALDÚA, 1999, p. 25-26)

4- "Huitzilopochtli, the God of War, guided them to the place (that later became Mexico City) where an eagle with a writhing serpent in its beak perched on a cactus. The eagle symbolizes the spirit (as the sun, the father); the serpent symbolizes the soul (as the earth, the mother). Together, they symbolize the struggle between the spiritual/celestial/male and the underworld/earth/feminine. The symbolic sacrifice of the serpent to the "higher" masculine powers indicates that the patriarchal order had already vanquished the feminine and matriarchal order in pre-Columbian America". (ANZALDÚA, 1999, p. 27)

5- "For the Indians, this constituted a return to the place of origin, Aztlán, thus making Chicanos originally and secondarily indigenous to the Southwest. Indians and mestizos from central Mexico intermarried with North American Indians. The continual intermarriage between Mexican and American Indians and Spaniards formed an even greater mestizaje". (ANZALDÚA, 1999, p. 27)

6- "She can't go home. She's sold her house, her furniture, borrowed from friends in order to pay the coyote who charges her four or five thousand dollars to smuggle her to Chicago. She may work as a live-in maid for white, Chicano, or Latino households for as little as \$15 a week". (ANZALDÚA, 1999, p. 34) 


\subsection{Libertar a rebelde: práticas discursivas e produção de sentido}

Ser "rebelde" significa (re)delimitar estruturas consolidadas no tempo que, por certo, enunciam necessidades adequadas a certos sonhos e aspirações pelos quais o indivíduo se empenha em conseguir em determinado período. Ser rebelde significa dar a palavra, e ao mesmo tempo tomá-la para caracterizar a infinita reunião de possíveis níveis discursivos quando se está construindo a imagem de si para, então, projetá-la no mundo. Ser rebelde significa trocar os sentidos, equivaler experiências, multiplicar o esperado. Rebeldia, ainda, pode ser uma forma por meio da qual o discurso corre no tempo e no espaço, deixando marcas quando cruza o reverso de uma frase, quando deixa inexata a polissemia da palavra ou, quando solicita um novo tratamento para seus propósitos.

Ser "rebelde", por fim, é quando, "minha" palavra se encontra inscrita em algo vivo e consegue se transformar e transformar o outro.

O resultado é que, nesse intervalo, o fio a ser seguido pelo discurso toca em tantos outros fios que é quase impossível a nuança dos sentidos refletir uma única pergunta, ou uma única resposta.

O caráter progressista desses princípios surpreende, assim como surpreende a progressão das "realidades rebeldes" apresentadas por Anzaldúa no capítulo "Movimientos de rebeldía y las culturas que traicionan" (p. 37 a 45), com um tipo de linguagem desenvolvida para dinamizar consciências e cercada de códigos que ela enuncia nesse espaço.

Permanecendo livre e igual em direitos para levar seu discurso adiante, a autora só percebe, "bem mais tarde", que a democracia não excluiria ninguém, exceto os estrangeiros que, como ela, sentem-se vítimas da destruição de seu Estado, ou de seu "lar", afrontados que foram pela soberania de espanhóis e norte-americanos. 
Longe de proclamar um igualitarismo natural entre "eles" e "nós”, Anzaldúa denuncia todo tipo de distinção social sofrida ao longo do tempo e diz ter perdido o direito à essa mesma liberdade e à propriedade e que, por isso, resiste à opressão baseando-se em uma natureza humana universal. O que se desenha diante de nossos olhos, portanto, não é de admirar. Ela expõe o seguinte testemunho:

Esses movimentos de rebeldia que, nós, mexicanos temos no sangue, surgem como rios deformados em minhas veias. E como minha raça que de vez em quando deixa cair essa escravidão de obedecer; de calar-se e aceitar; em mim está a rebeldia sobre a carne. Sob meu olhar humilhado está um rosto insolente pronto a explodir. Minha rebeldia me custou muito caro - adormecida com desvelos e dúvidas, sentindo-me inútil, estúpida, e impotente. $\left(1999\right.$, p. 37) ${ }^{1}$

Com certeza, a violenta impossibilidade de se fixar em um única crença faz Anzaldúa tirar outros benefícios desse espírito espontâneo, mas, ao mesmo tempo, bastante polêmico. Ela demonstra que, ao ter feito uma escolha para ser a "diferente", acrescentou à sua paixão pela alteridade, muitos outros movimentos que revelam a origem de suas lutas, ou seja, o encontro, dentro de si, de um "rio de sangue". É como se ela tivesse desencadeado a combustão do amor e do ódio que geram as forças para não sucumbir a toda essa provocação.

Dessa forma, nenhuma outra acumulação de sentidos como os citados pode funcionar dentro da autora, se não houver uma lenta maturação de todas essas questões, pois, as figuras de sua aceitação como a estranha podem variar; ora são encaradas como defeito, ora como coragem, e até mesmo como ousadia.

A certeza para se entender toda essa violência vem das crises de ela conceber e representar diferentes religiões tais como a católica e a indígena, assim como afirmar-se na cultura espanhola e mexicana, além de mediar entre diversificados preceitos morais, cujos resultados nunca sabe onde vão desaguar.

Sendo assim, Anzaldúa não se fixa em nenhum deles, mas coisifica essa estranheza dentro de si, para, mais tarde, transformá-la em discurso que passa dessa estratégia para 
aquela instância. Uma vez que a autora pode apenas perceber a estranheza ou senti-la, sem, contudo, conseguir dar-lhe contornos definitivos, a melhor percepção dessa vinculação, é refletir sobre todas essas "diferenças" pessoais, traçando um paralelo entre si mesma e sua cultura. Segundo Kristeva,

\begin{abstract}
Símbolo do ódio e do outro, o estrangeiro não é nem a vítima romântica de nossa preguiça habitual, nem o intruso responsável por todos os males da cidade. Nem a revelação a caminho, nem o adversário imediato a ser eliminado para pacificar o grupo. Estranhamente, o estrangeiro habita em nós: ele é a face oculta da nossa identidade, o espaço que arruína a nossa morada, o tempo em que se afundam o entendimento e a simpatia. Por reconhecê-lo em nós, poupamo-nos de ter que detestá-lo em si mesmo. Sintoma que torna o "nós" precisamente problemático, talvez impossível, o estrangeiro começa quando surge a consciência de minha diferença e termina quando nos reconhecemos todos estrangeiros, rebeldes aos vínculos e às comunidades. $(1994$, p. 9)
\end{abstract}

Atravessando esse reconhecimento é como se fosse difícil, senão impossível para Anzaldúa, reconhecer e também gerar esse monstro que se aglomera em suas entranhas. Quantas vezes, dia e noite, ela teria tido a ilusão de configurar sua saída de dentro de si por meio de uma palavra acusando uma "ferida aberta" na alma, ou um corte no processo de desamor, naquela dor psíquica de amar, anulando a sequência de seus pensamentos maus? Quantas outras unidades dessa estranheza ela reconheceu e multiplicou dentro de si em um movimento de acesso à simbolização, para poder investir em outras partes de seu Self?

Essa concepção trata a subjetividade como um tipo de "instância interna" a partir da qual as vivências individuais adquirem um tipo de movimentação pulsional tentando salvar a unidade de uma fantasia perdida. Intensificada essa dor que não atenua, pouco a pouco, qualquer perda se liga à dor da perda da "coisa" amada, e o desejo volta intenso, a confrontar o sujeito, agora transtornado.

Por meio de diversas hipóteses, podemos responder que Anzaldúa se encontra diante da mais extrema dor interna quando confronta suas subjetividades com o estranhamento que carrega dentro de si. Ela reage à dor inclinando-se para o caminho das letras do qual tira sua 
contextura para compor as peças de seu jogo discursivo e de sua rebeldia e, portanto, atravessa os limites para além de qualquer lesão íntima.

Ela, de certa forma, é rústica, bastante diferente de nós, canibal quando "engole" algumas ordens hegemônicas, contudo, não desprovida de talento para questionar seus costumes e ter a tendência de não seguir outros. Afinal ela é lésbica e, assim, foge às regras da sociedade machista que gostaria de controlar todas as fêmeas.

Envolta em palavras e colocada no lugar de outros bichos alucinantes, a estranheza (ligada ao self), ou o estrangeiro dentro de nós, exprime nossos medos e reconhecimentos, desenrolando o fio do inconsciente ligado a nosso próprio corpo.

Mais do que isso, o estrangeiro inventa frases, duras ou emocionantes e se faz deslizar por um inferno de outras palavras que permanecem em mim e no outro. Ele tem seu itinerário definido e nos observa e às nossas direções, dependendo dos objetos que queremos recriar ou "matar" dentro de nós. Seu objetivo é indefinido e desconhecido; entretanto, ele atinge intensamente aquele que se encontra envolvido com a diferença, e desencadeia a dor psíquica, aquela da alma, ou a dor de amar.

Por outro lado, a própria singularidade da estranheza força e produz manifestações de raiva, algumas vezes, de medo, quando não de alegria, para, só depois, bem mais tarde, quando identificamos se o "valor" ou a "coisa" perdidos eram ou não eleitos por nós, afirmarse como concórdia ou discórdia de nossas esquisitices. Sendo assim, a velha frase de Montaigne cabe aqui, como uma advertência: "Somos duplos em nós mesmos" (disponível em <http://www.universodoconhecimento.com.br/content/view/100/57>). Acesso em: 12.nov.2008.

Nesse sentido, as inquietantes ideias de Anzaldúa sugerem uma nova ética, diferente, com direito a singularidades que, na tentativa de nos fazer observar a própria dor, traça a continuidade de se sentir ameaçada pelo território de sua felicidade, pois ela comenta que 
"Me dá uma raiva quando alguém - seja minha mãe, a Igreja, a cultura dos anglos - me diz faça isso, faça aquilo sem considerar meus desejos" ["Me entra una rabia cuando alguiensea mi mamá, la Iglesia, la cultura de los anglos - me dice haz esto, haz eso sin considerar mis deseos".] (p. 37).

A partir dessa posição, percebemos o espaço móvel por meio do qual Anzaldúa desloca e retoma seus conflitos constitutivos da materialidade discursiva. Intensionando apropriar-se de acontecimentos do passado para atualizá-los, inseri-los em seu contexto para que produzam sentido, a autora adota uma posição que faz avançar na ordem da memória social para, então, aprofundar-se na representação do funcionamento dos implícitos. Implícitos aí, podemos entender o longo processo de subalternização que o chicano vem experimentando desde que se transformou em uma nova ordem discursiva social.

Agora já não se trata de afirmar que o chicano é subalterno aos espanhóis e a norteamericanos, mas, também, e de forma mais inquietante, à Igreja. As diferenças coloniais saltam, mais uma vez, do imaginário para se concretizarem nessa forma de testemunho praticado por certos escritores, inclusive no de Anzaldúa. A colonialidade do poder parece estar presente nos mais diferentes valores e, ao passarem destas mãos para aquelas, formam histórias, perpetuam ideologias.

Nesse processo de transformação, a colonialidade do poder motiva, talvez, toda uma espécie de conflito imperial, articulando-se por meio de uma turbulenta memória social. É próprio da história tentar encontrar e formular conceitos que extrapolem ou expliquem esses complexos fenômenos sociais. Os expostos por Anzaldúa, em sua deliberada extravagância, ou em sua rebeldia, sugerem o sentido atribuído à transculturação, ou melhor, oferecem a visão das diferentes interações que se fazem necessárias entre os povos para resultar no novo cenário sócio-cultural. Mesmo "raivosa", muitas vezes, ela precisa submeter-se à vontade do outro para ser aceita. Ela percebe essa "verdade" e faz acordos. 
A partir de então, o momento histórico deixa de considerar o eurocentrismo como projeto global, que situava "a Europa como ponto de referência e de chegada", para referencializar um novo espaço (MIGNOLO, 2003, p. 41). A estrutura funcional, agora, mostra uma mudança em que "saberes locais" se interseccionam àqueles "projetos globais" de uma antiga posição unilateral. E mais, aquela posição de não se aceitar o "Outro" como "mistura", promoveu a conquista de se desestruturar a antiga hegemonia para fomentar a importância de novas subjetividades.

Por meio do reconhecimento de saberes locais populares, foi possível a um discurso qualificado ilegítimo como o de Anzaldúa galgar os limites da diferença colonial e estabelecer-se enquanto referente da cosmovisão pós-moderna, ou seja, a inclusão de sociedades consideradas marginalizadas nesses universos dissociados, unificou o reencontro em si mesmos.

Não é preciso dizer que Anzaldúa considera todas essas camadas comunicacionais como um crescimento. Segundo ela,

Pero he crecido. Já não passo minha vida expulsando os valores e costumes da minha cultura que me denunciam. Também tenho guardado os costumes que tenho experimentado e os costumes que dizem respeito às mulheres. Mas, apesar de minha crescente tolerância, para esta chicana, a guerra pela independência é uma constante. $(1999$, p. 37)

Esta dupla equação entre ser rebelde, e aceitar outras discursivizações somente pode ser considerada quando Anzaldúa consegue transcender as antigas dissociações para se tornar essa mulher de letras, politizada, e criar em seu discurso aquele "ser espiritual” já consagrado pelo "impuro". Essa forma de se projetar permite que reconheçamos, na transição do real para o simbólico, o prazer que acalma e engole a neurose do estrangeiro.

A equação considera a divisão entre dois "mundos" o avesso de uma divisão entre dois países, ou a divisão no interior da própria unidade. Os estrangeiros apenas reencontrarão uma identidade quando se reconhecerem como a união de uma heterogeneidade que os recolocam 
no interior de si mesmos e no interior do Outro, feito um movimento de performatividade. $\mathrm{O}$ "Eu" e o "outro" precisam ser considerados na nova formação de identidades diferenciadas, abarcando e transformando tudo o que havia da antiga camada identitária.

O reconhecimento de um possível "nós/eles" somente será efetivado quando, ao passar por essas clivagens, o estrangeiro puder reconhecer em si mesmo aquela heterogeneidade caminhando em direção a uma unidade (social) que, afinal, se desfaz e torna a se fazer, fundamentando o nascimento do "novo".

Então, o estrangeiro se perceberá em um "mundo" onde não há mais latinos, nem negros, judeus, nem bárbaros, sequer homens livres, mas aquela renovação que se faz presente em todos nós, incluindo "ele" e "eu".

De fato, o objeto interno fundamental precisou ser produzido pela interiorização de uma "união" que, por meio da clivagem geradora de angústia, é vivida como a "guerra pela independência”, a viagem constante das mutações enfrentadas pela autora.

Como qualquer outro chicano que sonha retornar à terra perdida, Anzaldúa se aventura em aproximar-se daquela superfície que é ao mesmo tempo estranhamento e reencontro, falta e desejo, tudo misturado, para apresentar no seio de um só conjunto político, seus contrastes entre a tradição chicana e a pós-modernidade.

Mais do que qualquer desavença amorosa, ou social, ou evento mutatório, a possibilidade de dar e acolher é o importante para Anzaldúa nesse momento. Ela guarda alguns costumes e já não expulsa outros. Ao invés disso, ela tenta conjugar esse seu espaço de enunciação com aquelas entidades conceitualizadas como configurações do mundo.

Em um outro contexto, suas crenças religiosas, nacionais ou as relacionadas aos preconceitos étnicos silenciam de maneira implícita algumas vezes, para, um tempo depois, serem novamente retomados de uma posição cujas especulações confrontam a reflexão incorpórea da consciência ou da sua autoconsciência. 
Nesse processo, as constantes mudanças produzem diferentes resultados na "formação" de suas identidades. Senão, como organizar a base da estrutura identificando o surgimento de novas posições de identidade se a todo momento as demandas em termos de seus bens culturais ("costumes e valores de minha cultura") ["las costumbres y los valores de mi cultura”] (p. 37), migram desse processo de desigualdade para aquele outro, gerador de um fator de atração?

Ela argumenta que esses novos movimentos historicizam suas experiências, pois enfatizam as diferenças de como eram os costumes da comunidade e como são agora com relação à mulher chicana.

Anzaldúa toca aqui, novamente, nas fronteiras que, como temos visto, podem se tornar abrangentes e abusivas, opressoras ou hospitaleiras por meio de sua discursivização, mas que, sem dúvida, obrigam o "estrangeiro" a ser um peregrino constante, "sujeito" errante, tentando unir os diferentes, estabilizar os dados exteriores numa forma de exprimir os restos do recalque que não puderam agir.

Graças à impossibilidade de a autora poder manejar seu desejo como gostaria, de forma direta e acabada, as fronteiras, então, reinam e disputam o direito de emitir a anexação do desejo, a esse ou àquele território.

Aos mais afoitos, aos "rebeldes" como Anzaldúa, tais circunstâncias promovem funções que asseguram o movimento de ir-e-vir, raras vezes não cruzando com outros limites, expressos em qualquer outra relação de classe, nação, ou trabalho. E no centro dessas relativizações estão as ideias heterogêneas versando por ideias revolucionárias que, sem se identificar com nenhuma facção específica, defendem a miscigenação dos sentidos expressos nas performatividades mais originais possíveis.

Talvez seja por isso que a tolerância de Anzaldúa, nesse momento, se apresente de forma crescente, e articule novas tendências valorizando tanto o lado cultural quanto o 
político do chicano. Quem mais senão a cultura para constituir significados que veiculam valores e, em consequência, impregnam-se de valores políticos? A quem mais senão à política, Anzaldúa deveria se dirigir para responder a pergunta: e agora, o que fazer? De acordo com Bhabha, "Um saber só pode se tornar político através de um processo agnóstico: dissenso, alteridade e outridade são as condições discursivas para a circulação e o reconhecimento de um sujeito politizado e uma "verdade” pública" (1998, p. 49).

Pensar sobre uma prática política cultural, espaço onde também já identificamos Anzaldúa, contribuiria para confirmar a relação entre o interesse pela cultura marginal e sua marca afiliando-se ao social. Se essa diversidade precisa ser enfrentada para evidenciar sua prática intelectual, a nossa conclusão é a de que todos precisamos de uma mudança de consciência para percebermos uma atmosfera intelectual diferente espalhada por setores mais amplos da sociedade, provocadora de mudanças que, com a ajuda da globalização, jamais produziu efeitos tão interessantes.

Para Anzaldúa, portanto, a acumulação de ideias e de forças para lutar, não cabe em um único espaço de eventos, mas, por outro lado, sua "guerra de independência é uma constante" ["la guerra de independencia is a constant."] (p. 37). As esferas de suas ações não têm fim e mudam à medida que se espalham por outras direções. Sendo assim, um único pensamento não se acomoda à sua escolha ou a seu sistema expressivo e, então, os efeitos de sentido legitimam mudanças sócio-culturais e políticas, tanto quanto chamam a atenção para sua resistência anti-hegemônica presente em todos os espaços intervalares de seu hibridismo discursivo. E qual seria essa reação?

Se Anzaldúa participa ativamente de projetos mutantes na "guerra", ela reescreve a história chicana coordenando atividades sociais e culturais que lhe possibilitam recolher o que foi desvalorizado pelo contínuo avanço do opressor. Na esteira dessa conscientização, a 
autora não se deixa atrair por outras formas socialistas. Ela tem as suas próprias e é por elas que luta.

Em seu processo de subjetivação, Anzaldúa é vista como aquele sujeito que ocupa uma nova posição paradigmática, tentando rearticular e reconstruir a identidade chicana, percebida como ambivalente desde o início.

Segundo Freud (1981), o próprio processo de identidade é ambivalente. Em seu artigo escrito em 1915, Luto e melancolia, a identificação aparece não como aquilo que aprisiona o bebê a um objeto externo idealizado (mãe), mas como aquilo que se prende ao objeto perdido. Ele, bebê, inicialmente projeta sua libido em forma de idealização ao objeto amado (ou odiado), para depois, compensar a perda dos prazeres libidinais "ingerindo" o objeto que preza. Assimila-o pela "ingestão" (o bebê agora é o outro), ao mesmo tempo que o aniquila como tal (ele tem o Outro).

Essa discussão ilustra a ideia que Freud sustenta ao argumentar que o ato de identificação desenvolve a distinção entre "ser" e "ter" o Outro.

Nesse sentido, a analogia que podemos estabelecer em relação à Anzaldúa, obedece à lógica de que ela se identifica com o objeto perdido "mãe terra", ingerindo esse objeto amado para, então, simbolicamente, "ser" e ao mesmo tempo "ter" o Outro, essa mãe. Dessa incorporação, nasce a articulação sobredeterminada em "ser" chicana, enquanto reconhece que "tem" o poder de assegurar-se como sujeito de um discurso político, levando-a a estabelecer construções sobre a Raza.

Permanecendo dentro ("é”) e fora ("tem”) de projetos locais, por meio de suas estratégias específicas, Anzaldúa consegue construir a identidade chicana "dentro" de uma sociedade que a reconhece como aquela que está "fora" dos padrões estabelecidos pois, segundo ela, 
Há uma rebelde em mim - a Besta das Sombras. É aquela parte de mim que se recusa a obedecer ordens de autoridades externas. Ela se recusa a obedecer ordens de meu desejo consciente, ameaça a soberania das minhas normas. É aquela parte de mim que odeia restrições de qualquer tipo, até mesmo daquelas auto-impostas. À menor insinuação de limites sobre meu tempo ou sobre meu espaço dada por qualquer pessoa, ela chuta com os dois pés. Bolas. $(1999 \text {, p. } 38)^{3}$

Dessa forma, Anzaldúa não se deixa abater pelo entusiasmo do outro. Ao contrário, quando ela sente-se ameaçada de qualquer forma, responde a esse conjunto crítico de uma maneira que interpela, pela "fala", qualquer "sujeito" que queira assumir sua posição. Dessa bem-sucedida articulação, a autora introduz a ideologia de que, investidos de histórias construídas ao longo do tempo por uma "fala" diferenciadora, os chicanos estruturam suas identidades, sempre em movimento.

Por outro lado, a "rebeldia" não é vista por Anzaldúa como problema mas sim, como a saída dessa indistinção que classificava a etnia como "nada". O seu "desvio" será o caminho da criatividade e esta dá sentido à vida, modificando-a de acordo com a elaboração de seus afetos. Afinal, ela tem dentro de si a Besta, a "Coisa" diferente, distanciando-a de ser considerada normal.

Se, por um lado, ela não se identifica com a tendência de ser incluída no bloco dos normais, obedecendo ordens, ou de participar de categorias de pensamentos que a visionem como elemento obediente, por outro lado, sente-se inseparável do movimento de se conceber como a "diferença". O resultado de sua rebelião mostra um plano tático para organizar, de forma dissociada, o ataque verbal àquelas mentes controladoras de outras instâncias.

Nesse seu levante, Anzaldúa argumenta que seria muito mais eficaz fazer valer a circulação de ideias para a fronteira tão ambivalente do hibridismo ser encarada como estratégia política, do que disseminar sua revolta e concordar com novas ordens hegemônicas.

Para tanto, ela não se permite ser olhada como aquela que permanece inativa e deixa a conversa para o dia seguinte. Nesse intervalo, uma mente controladora poderia surgir e 
impedi-la de libertar-se a si mesma, e aos "irmãos". Anzaldúa traz no âmago o tesouro de possuir a "Besta das Sombras" e por nada permitiria que lhe tirassem essa liberdade.

Mesmo porque os rumores sobre o fato de a hegemonia silenciar a "rebelde dentro de mim", sempre desafiou o turbulento espaço onde se encontra a autora. Proibida de participar em outras posições sociais para traduzir a diferença, Anzaldúa argumenta que ultrapassa até mesmo sua capacidade de "autoimposição" e desenvolve maneiras de elencar alternativas que levem seu discurso a provocar o Outro para que se junte a ela e participe de suas ideias.

O impacto sobre o leitor é um estímulo constante, causado por ela. No interior de suas representações não há como lermos a possibilidade de ela ser (i)limitada em sua discursivização, e permanecermos indiferentes a seu chamado. Suas interessantes representações não negam o que desapareceu com a influência da cultura dominante - ao contrário, Anzaldúa aponta as perdas - e retoma essas elisões para, mais uma vez, provocar o leitor.

Anzaldúa também passa a ter uma atividade destruidora das tradições, do conservadorismo, à medida que provoca certos apagamentos, ou demonstra certos desvios das normas estabelecidas pelo discurso hegemônico.

Por outro lado, ela consegue impor uma imagem de si mesma dominando parte dessa representação dicotômica e assume a pulsão de agir, de pensar, para produzir o efeito sóciocultural de transformar pensamentos.

Os incidentes da sua vida fazem-na se movimentar por meio de forças desiguais entre diferentes "espaços" e "tempos". Isso significa que a temporalidade social da qual as suas histórias emergem, marca o conflituoso signo das manifestações culturais originadas no interior dessas fronteiras.

Mais do que nunca, a vantagem dessa posição assumida por ela vem desenvolver historicidades teórico-culturais sobre a tradição e a cultura chicanas. Sem deixar de revisar a 
complexa estrutura de sua "identidade" cultural, de seu povo, Anzaldúa assume o lugar híbrido do valor cultural, e transforma antigas convicções estabelecidas pelos embates e negociações eurocêntricas, em novas posições que devem modificar o jeito de ser do chicano. Segundo Yúdice, "Da mesma forma que os sujeitos são contraditórios mesmo que nivelados pelo nome, assim também é a impossibilidade da sociedade, constituída de uma multiplicidade de diferenças instáveis gerenciadas pela hegemonia” (2004, p.55).

Sendo assim, o presente enunciativo de Anzaldúa liberta seu discurso que, ao relacionar-se com outras sobreposições equivalentes, faz-nos frequentar as selvagens fronteiras delimitadas entre o que pode e o que não pode ser dito.

Para Anzaldúa é preciso redimensionar e pensar sobre essa questão de se repetir as estruturas discursivas. Ela deve ser encarada como a única condição de a autora poder dimensionar a "voz" adquirida para expressar a indeterminação identitária sob a qual os chicanos vivem há tanto tempo.

No texto de Anzaldúa, essas ideias são fundamentadas pela afirmativa: a "Cultura forma nossas crenças" e ela "é feita por aqueles no poder - os homens. Os machos fazem as regras e as leis; as mulheres as transmitem" ["Culture forms our beliefs". - "Culture is made by those in power - men. Males make the rules and laws; women transmit them".] (p. 38).

Para continuarmos nossas reflexões, seria interessante apontarmos as instâncias que, segundo Bhabha, influenciam a produção discursiva de qualquer sujeito. Trata-se do estabelecido entre "diferença" e "diversidade" cultural. Enquanto esta última é considerada um "objeto epistemológico", plausível de conhecimento empírico, a diferença cultural identifica a ética e a estética de um todo significativo, e refere-se sobre os povos nativos e seus costumes competindo referencializar, num processo de constante mudança, significâncias "através da qual afirmações $d a$ cultura ou sobre a cultura diferenciam, discriminam e 
autorizam a produção de campos de força, referência, aplicabilidade e capacidade" (BHABHA, 1998, p. 63).

Não devemos nos esquecer de que a diversidade cultural também origina noções sobre o multiculturalismo e seus intercâmbios culturais, além de mostrar aquelas culturas que, de maneira plena, permanecem quase "intocadas pela intertextualidade de seus locais históricos, protegidas na utopia de uma memória mítica de uma identidade coletiva única" (BHABHA, 1998, p.63).

Por outro lado, a noção de diferença cultural nos induz a perceber a "ambivalência da autoridade cultural" existente entre a tentativa de se "dominar em nome de uma supremacia cultural" e o "conhecimento da verdade no momento da enunciação" (BHABHA, p. 64). Para a diferença cultural ainda há, segundo Bhabha,

uma quebra entre a exigência culturalista tradicional de um modelo, uma tradição, uma comunidade estável de referência, e a negação necessária da certeza na articulação de novas exigências, significados e estratégias culturais no presente político, como prática de dominação ou resistência. (1998, p. 64).

Apenas quando compreendemos todas essas impressões podemos ter uma visão de como a cultura muda em consequência de discursos que, por um movimento de política revolucionária, conseguem articular como prática cultural o espaço indeterminado de sujeito da enunciação.

Se, como afirmado por Bhabha (1998), a diferença cultural perspectiviza um processo que discrimina, diferencia e autoriza campos de força, talvez seja por se perceber inserida nesses espaços que Anzaldúa toma a cultura como formadora de suas crenças. A autora sempre se percebeu discriminada, a "diferente", e, assim, autorizada a dizer o que considera essencial a ser conquistado pelo seu povo. Em consequência dessas discussões todas, houve o ganho de uma luta para que ela tivesse uma "voz" que a representasse nesse discurso hegemônico. 
A visão desses espaços faz, mais uma vez, o sujeito discursivo se perceber aberto para significar toda a movimentação flutuante de concepções, e agir de forma que explore o significado da cultura e de suas mudanças.

Por isso, uma das possibilidades de ela não se aceitar obediente e reagir à cultura e à Igreja, é o fato de não admitir que as mulheres sejam subservientes aos homens como determinam as convenções (p. 39). Anzaldúa afirma ter ouvido muitas vezes de mães e sogras que as mulheres precisariam apanhar de seus esposos caso elas não lhes obedecessem, ou se fossem linguarudas, ou fofoqueiras ou, ainda, se não cuidassem das crianças e do serviço de casa, como manda a tradição. ["I heard mothers and mothers-in-law tell their sons to beat their wives for not obeying them, for being hociconas (big mouths), for being callejeras (going to visit and gossip with neighbors), for expecting their husbands to help with the rearing of children and the housework".] (p. 38).

Anzaldúa não aceita essas normas e rebela-se contra o fardo que as mulheres de sua cultura precisam carregar. Dessa forma, ela compete para que seu discurso mostre as "diferenças", e seja ouvido para trazer mudanças nessa produção cultural. Ao explorar toda a oculta instabilidade dentro da cultura, Anzaldúa pressagia novas mudanças e começa a vislumbrar as diferentes histórias nacionais que transformam significados até mesmo da tradição de seu povo.

É documentando sobre os acontecimentos que ela narra, a tradição de a mulher chicana sentir-se oprimida pela cultura machista, pois esta determina diferentes identidades que são experienciadas pela mulher na contemporaneidade. Ela olha sobre todas essas manifestações e coloca uma nova opção para as mulheres chicanas de hoje: "introduzirem-se no mundo pelas vias da educação e da carreira, e tornarem-se pessoas autônomas" ["entering the world by way of education and career and becoming self-autonomous persons".] (p. 39). 
Neste momento, Anzaldúa parece fazer seu discurso para orientar as mulheres. Ela ativa uma estrutura que parecia estar consolidada há séculos e manifesta uma outra postura: as mulheres devem ser livres para escolher o que fazer da própria vida.

Sendo assim, nada seria mais justo do que a cultura chicana permitir a formação de uma nova classe dentro da própria etnia: a mulher sair do protecionismo masculino e ter o direito de escolher sua posição na sociedade. Nada de seguir o antigo conceito de que as mulheres sucumbiriam se não tivessem a mão do macho para guiá-las em todas as direções. Mais uma vez, a "rebeldia" da autora promove suas próprias colocações e ela se acha no direito de garantir mais essa liberdade às mulheres de sua Raza.

Ela aborda as dificuldades que enfrentou durante todo o processo de seu desenvolvimento (intelectual). Anzaldúa também mostra todas essas suas primitivas experiências, dolorosas, e acredita que toda mulher deve ser considerada como aquela das intensas sensações, pronta a se comunicar com ela mesma e com seus duplos.

Empreendendo essas audaciosas transformações, Anzaldúa frequentemente se desloca no tempo e no espaço para, de seu lugar, intervir na estrutura de significações culturais e, com seu discurso, referencializar novas possibilidades originando o hibridismo cultural de um Terceiro Espaço, o da enunciação. As repercussões dessa circulação de diferenças faz seus significados simbólicos produzirem o intercâmbio necessário para intervir nas outras maneiras significativas desse seu determinado processo de enunciação, e, com isso, resultarem em compreensões sobre a "verdade" chicana.

Assim, os diferentes setores da sociedade chicana veem-se, depois disso, como que desobstruídos das fontes de seus deveres, e na contramão dessa servidão, exigir os direitos de inclusão e participação de todos nessa sociedade global projetada para o futuro.

Podemos perguntar, a essa altura, se as noções de diferença cultural também não contribuiriam para considerarmos de que forma Anzaldúa estaria impactando seus leitores 
com tamanhas demandas a respeito de suas reivindicações, pois a produção da diferença cultural mostra, de forma objetiva, como os povos nativos e seus costumes, explodem em uma multiculturalidade, criando novos locais, visando o bem-estar social, além de conceder que as manifestações culturais, de uma forma ou de outra, encontram-se protegidas na memória mítica.

Sobre isso, o caminho escolhido por Anzaldúa foi o de produzir negociações no sentido de se fazer aceitar como uma "voz" para as mudanças necessárias, cujas repercussões eclodem na irrestrita contribuição de seu discurso, alertando o povo. Ela demonstra saber que na atual sociedade chicana, sempre em movimento e com múltiplas facetas, há a ideologia de se traduzir a busca de novos valores, representados por vários autores incluindo a si mesma, e que muitas outras metodologias também têm surgido para oferecerem novas posições identitárias a fim de que o povo tente sanar o conflito sobre a identidade cultural. De acordo com Bhabha,

\footnotetext{
O povo é agora o próprio princípio de "reorganização didática" e constrói sua cultura a partir do texto nacional traduzido para formas ocidentais modernas de tecnologia de informação, linguagem, vestimenta. O novo lugar de enunciação político e histórico transforma os significados da herança colonial nos signos liberatórios de um povo livre e do futuro. (1998, p. 68)
}

Nesse processo, o resultado final se compõe de várias partes. Foi criada uma mestiçagem como identidade cultural chicana, ao mesmo tempo que surgiram vários códigos linguísticos considerados "impuros” pelo discurso hegemônico, tais como o spanglish e o caló, por exemplo. Também observa-se a particularidade do nascimento de uma nova identidade étnica referindo-se às mulheres. Além do mais, essa nova sociedade mostra o "lugar" dessa identidade feminina à medida que a mesma sociedade tende à globalização, buscando novas formas de se definir.

A partir de então, Anzaldúa percebe os indivíduos ligados em si mesmos, vinculados uns aos outros por meio dos elos do trabalho. 
Os arranjos que têm ocorrido para que existam novos conceitos fomentando a liberdade das mulheres parecem claros quando Anzaldúa afirma que,

\begin{abstract}
Como pessoas da classe trabalhadora, nossa principal atividade é colocar comida em nossas bocas, um teto sobre nossas cabeças e roupas nas nossas costas. Educar nossas crianças é impossível para a maioria de nós. Educados ou não, o ônus de ser esposa/mãe ainda recai sobre as mulheres - apenas a freira pode escapar à maternidade. As mulheres são feitas para se sentirem fracassos totais se não se casarem e não tiverem filhos. $(1999, \text { p. } 39)^{4}$
\end{abstract}

O argumento subjacente a essas proposições é o de que, por meio desses processos sofisticados de libertação de si mesmas, as mulheres chicanas, hoje em dia, parecem assumir sua dimensão de autoridade e se posicionarem diante de um fenômeno que está mudando até mesmo aquele ponto de vista senhorial. Como "pensamento" e "fala", a nova mulher chicana atrai para si várias dimensões de estranheza e também afeta determinados momentos contraditórios da vida pública e privada. Considerada o sonho enlouquecido da esquerda, ela tenta eliminar o inimigo autoritário e seguir seu caminho livre da opressão do macho.

Todas essas mudanças refletem o desempenho do papel da mulher na sociedade, seus ajustes entre as várias imagens adotadas, ou seja, de mulher que quer ser livre, de ter seu processo de formação, e de como ela se distingue nesse novo momento pós-moderno, o tempo da reação.

Mais do que essas dimensões, a mulher chicana mergulha de cabeça nas causas defendidas pelo grupo e resiste até mesmo à pressuposição de que são empobrecidas espiritualmente. Dessa relação, surge o aspecto mais problematizador de suas manifestações: serem consideradas não revolucionárias e permanecerem nessa relação de produção identitária sem mudar nenhum valor.

Trata-se, agora, de as mulheres aprenderem a conviver com o paradoxo de pertencerem a uma tradição chicana, mas, ao mesmo tempo, precisarem ser universais à medida que se modificam com as mudanças do incerto. 
Como na atualidade não há um lugar certo para ninguém, e as mulheres pressupõem a ideia de que são um "corpo dotado de memória”, elas se transformaram no exemplo a ser estudado para significarem a mudança na cultura chicana.

E, assim, Anzaldúa referencializa todo o preconceito da sociedade machista, reforçado pelas mulheres: “E quando te casas, Gloria? O trem vai passar.” E eu lhes respondo; "Se eu casar não há de ser com um homem.” Elas ficam caladinhas. Sim, sou filha da Chingada. Sempre fui sua filha. Não fiquem me xingando." ["Y cuándo te casas, Gloria? Se te va a pasar el tren." Y yo les digo, "Pos si me caso, no va ser com un hombre." Se quedan calladitas. Sí, soy hija de la Chingada.” I've always been her daughter. No 'tés chingando”.] (p. 39).

De novo, sua crescente rebeldia reaparece para responder ao estabelecido pelas convenções sociais: para ela, essa decisão sinaliza a grande virada de sua cultura no século XX. Alternativas e decisões importantes são levadas em frente quando ela resolve contrapor o estabelecido pelas mudanças.

O que ocorreu? Anzaldúa é radical e usa isso para explorar as possibilidades de incertezas dentro de ambas estratégias: as legitimadas e as subvertidas pelas "fronteiras" da resignificação. A autora deixa que venha à tona o concreto de suas diferenças e mostra que, mais do que viver na fronteira, é necessário conseguir manter-se nessa marginalidade para poder manifestar, por meio de seu discurso, as ideias que a identificam como a "diferente".

Ao contrário de combinar realidades, Anzaldúa parece disposta a centrar sua luta pelas vias dos mais assombrados espaços para que, desse fantasma, surjam os conflitos com os quais a mulher tem de se compreender enquanto mulher. É chegado o momento em que precisa somatizar os tabus sociais e responder que "não há de se casar com um homem”. Com isso, ela desfaz um antigo terror ancestral para instalar esse outro: não há ninguém que a obrigue a se casar com um macho, pois ela é filha da Chingada, da Malinche, a "outra", 
também "diferente", aquela que, com sua habilidade, conseguiu convencer todo um povo a aderir a uma "novidade" imposta pelo estrangeiro espanhol.

Nesse cenário, as contribuições de Anzaldúa revelam personagens com "vida" própria cuja semelhança com seu criador ocorre durante toda a narrativa de Borderlands. Segundo Pérez-Torres,

\begin{abstract}
Nenhum autor chicano recorre à fronteira mais frequentemente do que Gloria Anzaldúa. Presa entre os mundos do lesbianismo e do heterossexual, do mexicano e do americano, Primeiro e Terceiro Mundos, Anzaldúa constrói uma poesia que procura exemplificar e refletir a condição do interstício e do limite de estar simultaneamente entre e sobre o limiar [...] a mestiçagem inerente às fronteiras: "viver nas fronteiras significa ser você / não é nem hispânica indígena negra espanhola / sequer gabacha, eras mestiça, mulata, meio-espécie / presa no fogo cruzado entre os campos / enquanto leva todas as cinco raças nas costas".

As fronteiras [...] tornam-se zona de transição e de não-pertencimento. Você não é hispânico, indígena, negro, espanhol, ou branco, mas mestiça. A identidade emerge da mistura racial, cultural, sexual. É uma terra de traição onde "mexicanas chamam você de rachadas" e "negar o anglo dentro de você / é tão ruim quanto ter negado o indígena ou o negro". Uma mestiçagem da identidade linguística e sexual também emerge na fronteira: "Quando vives na fronteira / as pessoas vêm até você, o vento rouba sua voz, / você é uma burra [asno], buey [mule], bode expiatório / [...] / ambos mulher e homem, nenhum - / um novo gênero" ... Viver nas fronteiras significa transgredir as rígidas definições de sexo, raça e gênero. $(1995$, p. 94-95)
\end{abstract}

Alternando o "vivido" pelas personagens com o "vivido" na sua discursivização, Anzaldúa, portanto, remete essa outra personagem, ela mesma, para aquele contador de histórias, cuja memória se mostra conhecedora tanto da tradição chicana, quanto do processo de mudança, para se perceber a "mistura" resultante desses dois espaços. Investida circunstancialmente de elementos afetivos particulares, ela reativa a imagem mnêmica de todo um passado feminino e manifesta outras perturbações, ligadas entre o "antes" e o "depois".

Sendo assim, a personagem de Anzaldúa surge de dentro da história chicana, heroica , explicando, com sua crítica/escritura, todas as dificuldades que tem encontrado para livrar-se da opressão vivida por qualquer tipo de hegemonia. Sua "voz" não é a de uma mulher desolada, sequer deslocada, mas daquela que foi removida de seu local por vontade própria, e que, por isso mesmo, não se cala nem foge aos compromissos de sua autoria feminina. Para Bhabha, "Ao romper a estabilidade do ego, expressa na equivalência entre imagem e 
identidade, a arte secreta da invisibilidade da qual fala o poeta migrante muda os próprios termos de nossa percepção da pessoa" (1998, p. 79).

Por isso, ao transpor os limites de uma distância para outra, Anzaldúa dissolve qualquer discurso contrário a suas ideias e constrói concepções em torno de sua capacidade de conceber inovações para poder renunciar a outras manifestações. Se ela aderiu à ideia de que não deve se casar com um homem, por exemplo, ela precisou se desfazer de toda uma carga social que não perdoa quem "sai da linha" e desobedece as ordens sociais estabelecidas.

Pelo fato de ser encontrada nesse tipo de resistência, ela se opõe à autoridade colonial e demonstra que o processo ameaçador dessa transformação cultural acontece quando enfrenta seu destino e se considera a outra forma do próprio sistema de migração. Para evitar "ser olhada" como a intolerante, sua pluralidade significativa remete-a aos contraditos culturais, até então considerados como signo nativo aceito no meio de sua civilização, e cria um despertar de consciências até então percebidas apenas como a dor inicial esquecida.

Na própria prática de dominar o outro discursivamente, Anzaldúa prioriza o veículo da

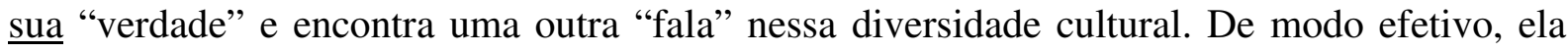
permanece nessa contínua difusão e espalhamento de significados, e representa o conjunto dos excluídos, daqueles que parecem inconciliáveis com o resto do sistema.

Por conseguinte, é preciso ler nas entrelinhas que, pelo fato de ela ter escolhido passar de uma fronteira a outra, a obra de Anzaldúa não pode ser rotulada por categorias estruturais específicas do texto ou ser analisada por uma única abordagem crítica convencional. Seu objetivo, como temos visto, é elaborar processos que investiguem e descrevam estratégias de identificação com sua cultura, assim como interpretar o "povo" e a "identidade" chicanos, para que sirvam como "objeto" de suas narrativas, e de seu "viver" literário diferenciador.

Se é assim, enquanto o pensamento historicista produz (apenas) uma contrabalança linear e supostamente empírica entre eventos e ideias que resultam nos significados de um 
povo, de uma nação, ou de uma cultura, Anzaldúa volta sua atenção para os conteúdos experienciados pelas diásporas e pelas migrações, e dá continuidade ao contingente performativo da diferença cultural, e não apenas ao pluralismo ou à diversidade cultural.

Ela convoca a população para modificar as dificuldades apresentadas pelo meio ambiente externo real e parece ser atendida, uma vez que está construindo uma nova consciência mestiça (1999, p. 99). É nessa cisão entre historicidade e performatividade que a narrativa de Anzaldúa aparece, sempre conflituosa.

Quando, porém, examinamos o papel desempenhado por Anzaldúa na cultura, percebemos que sua agressividade, sua rebeldia, é o resultado de uma ambivalência que, a essa altura, deve ser considerada como a severa restrição imposta pela cultura aos indivíduos para ser cumprida como obediência. O superego cultural destaca-se na severidade de suas ordens e proibições pelo fato de ele se preocupar muito pouco com a felicidade do ego, assim como considerar insuficientes as resistências contra a obrigação de obedecer ordens. Ele emite uma ordem e não pergunta ao indivíduo se é possível cumpri-la ou não.

Não causa admiração, dessa forma, que o discurso de Anzaldúa evidencie o sofrimento, o medo de ser considerado o "outro", o estranho, pois ela aponta que a "cultura [...] mantém as mulheres em funções rigidamente definidas" [“culture [...] keeps women in rigidly defined roles"], e que as meninas e mulheres deveriam se manter longe dos homens, uma vez que o conselho das mães é o seguinte: “Os homens querem uma coisa só; os homens não são passíveis de crédito, eles são egoístas e igual a crianças" ["Los hombres nomás quieren una cosa; men aren't to be trusted, they are selfish and are like children”.] (p. 39).

Partindo, pois, dessa geografia cultural, Anzaldúa acrescenta logo em seguida que,

Por intermédio de nossas mães, a cultura nos dá mensagens misturadas: Não vou permitir que algum desgraçado maltrate meus filhos. E logo em seguida a cultura diz que, a mulher tem de fazer o que lhe ordena o homem. O que a mulher dever ser - forte, ou submissa, rebelde ou conformada? $\left(1999\right.$, p. 40) ${ }^{6}$ 
Sob a pressão de todas essas possibilidades, Anzaldúa mostra estar sob a ameaça de um sofrimento vindo de três direções: do próprio corpo, ameaçado de ser possuído e escravizado pelos homens (os homens querem uma coisa só); do mundo externo, leia-se cultura que se voltou contra ela com sua força de destruição (não é aceita como mulher "diferente"); e de seu relacionamento amoroso com os "homens" (se eu me casar, não há de ser com um homem).

Dessa maneira, a reação imediata da autora para escapar da dor de sofrer seria o isolamento voluntário que é o caminho preferido pelas pessoas para manter distância das outras pessoas que nos fazem sofrer. Se contra esse temível mundo externo só podemos nos defender afastando-nos dele, essa seria a chamada "felicidade da quietude".

Entretanto, Anzaldúa não escolhe o caminho do isolamento. Pelo contrário, ela se torna membro da comunidade e, com o auxílio do caminho das letras pelo qual optou, passa a atacar a ética cultural que lhe foi imposta, e sujeitá-la à sua vontade. Assim, a autora consegue evitar o sofrimento: submete o "Outro" às suas próprias sensações. Nessas ocasiões, ela parece afastar-se da pressão imposta pela realidade e encontrar forças para sua luta num outro “mundo", próprio, que construiu procurando melhores condições de adaptação. Aqui, ela usa a técnica de lidar com a literatura para continuar vivendo.

Anzaldúa, porém, está firmemente ligada à realidade pela temática que inscreve em seu trabalho. Esse espaço lhe fornece o lugar seguro que ela necessita para se integrar na comunidade e não deixa, de forma alguma, esses seus deveres em segundo plano. Ela comenta que "O trabalho manifesta as mesmas necessidades de uma pessoa, ele precisa ser "alimentado", "tenho de banhá-lo e vesti-lo" ["The work manifests the same needs as a person, it needs to be "fed", la tengo que bañar y vestir".] (p. 89).

A atividade profissional constitui, assim, fonte de prazer especial para Anzaldúa, pois "abraçar as letras" foi um caminho escolhido livremente. Ela deixou o Vale Grande onde 
morava, e a família, e por meio da sublimação, transferiu todo o amor depositado naquelas disposições, para essa nova escolha.

Reconhecendo, então, que Anzaldúa atingiu um “direito" seu em oposição a um poder individual, percebemos que essa substituição gera o passo decisivo de se inserir numa cultura. Ela busca em outros companheiros, nos "irmãos", esse mesmo direito e valor culturais, com os quais é útil conviver. Anzaldúa descobre que, com sua força, ela pode se firmar na luta contra tantos outros adversários, sem, contudo, prever qual será o resultado ou o sucesso obtido.

A cultura, porém, exige outros sacrifícios da parte de Anzaldúa, ou seja, uma nova forma de vida que só pode ser alcançada quando ela se achar em condições de não restringir seus instintos e se declarar acima das severas restrições sexuais impostas pela sociedade machista. Ela comenta que

\begin{abstract}
As mulheres estão no fundo da escada que alguém dependurou sobre os transviados. O chicano, mexicano, e algumas culturas indianas não têm nenhuma tolerância com eles. O desvio é tudo aquilo que é condenado pela comunidade. A maioria das sociedades tenta se ver livre deles. A maioria das culturas queimaram e bateram em seus homossexuais e outros que se desviaram da sexualidade normal. Os queer são o espelho refletindo o medo da tribo heterossexual: ser diferente, ser outro e, portanto, menor, sub-humano, inumano, não humano. $\left(1999\right.$, p. 40) ${ }^{7}$
\end{abstract}

Vemos aí exposta, toda uma espécie de policiamento alienando, com regras extremadas, o desenvolvimento do ser humano. A cultura reprime o instinto, agride, mantém cativo todo aquele que se quer libertar dessas opressões. A tendência é destruir todo aquele que se desvia das normas do meio em que vive. Sob controle e pressões impostas, a cultura machista ameaça a felicidade humana na tentativa de dirigir suas atividades sexuais para um laborioso treinamento a fim de que se aprenda com os exemplos dos modelos heterossexuais.

O testemunho de Anzaldúa é o de fazer-nos conhecer toda a "estabilidade da ordem" que, nessa cultura patriarcal, constitui a forma mais forte de agressão feita às escolhas sexuais 
do outro. Em outras palavras, o papel desempenhado pelo superego cultural promete ainda, mais uma vez, fazer cumprir a repressão contra aquele que se rebela com o sistema imposto.

Na contramão dessas possibilidades instala-se Anzaldúa e sua "rebeldia", esta, a única ferramenta capaz de salvá-la de ser fagocitada pelo sistema, e de cuidar de suas ideias para não ser cooptada por inteiro.

Sentindo-se a "outra", a "desviada", Anzaldúa deu início à sua trajetória de sair das sombras e de carregar, com orgulho, a tarefa de mudar consciências, nessa travessia perigosa dos imensos territórios às vezes assustadores, mas que precisam ser percorridos, caso ela queira fazer valer todas as suas diferenças e toda sua memória histórica.

\section{NOTAS}

1- "Esos movimientos de rebeldía que tenemos en la sangre nosotros los mexicanos surgen como ríos desbocanados en mis venas. Y como mi raza que cada en cuando deja caer esa esclavitud de obedecer, de callarse y aceptar, en mi está la rebeldía encimita de mi carne. Debajo de mi himillada mirada está una cara insolente lista para explotar. Me custó muy caro mi rebeldia - acalambrada con desvelos y dudas, sintiéndome inútil, estúpida, e impotente”. (ANZALDÚA, 1999, p. 37)

2- "Pero he crecido. Ya no sólo paso toda mi vida botando las costumbres y los valores de mi cultura que me traicionan. También recojo las costumbres que por el tiempo se han probado y las costumbres de respeto a las mujeres. But despite my growing tolerance, for this Chicana la guerra de independencia is a constant". (ANZALDÚA, 1999, p. 37)

3- "There is a rebel in me - the Shadow Beast. It is a part of me that refuses to take orders from outside authorities. It refuses to take orders from my conscious will, it threatens the sovereignty of my rulership. It is that part of me that hates constraints of any kind, even those self-imposed. At the least hint of limitations on my time or space by others, it kicks out with both feet. Bols". (ANZALDÚA, 1999, p. 38)

4- "As a working class people our chief activity is to put food in our mouths, a roof over our heads and clothes on our backs. Educating our children is out of reach for most of us. Educated or not, the onus is still on woman to be a wife/mother - only the nun can escape motherhood. Women are made to feel total failures if they don’t marry and have children”. (ANZALDÚA, 1999, p. 39)

5- "No Chicana author addresses the borderland more frequently than Gloria Anzaldúa. Caught between the worlds of lesbian and straight, Mexican and American, First and Third World, Anzaldúa constructs poetry that seeks to exemplify and reflect the condition of the interstitial and liminal - of being simultaneously between and on the threshold [...] the mestizaje inherent to the borderlands: "To live in the Borderlands means you / are neither hispana india negra española / ni gabacha, eres mestiza, mulata, half-breed / caught in the crossfire between camps / while carrying all five races on your back / not knowing which side to turn to, run from [...]" The borderlands [...] become a zone of transition and not-belonging. You are not Hispanic, Indian, black, Spanish, or white, but mestiza. Identity emerges from the racial, cultural, sexual mixture. It is a land of betrayal where "mexicanas call you rajetas" and "denying the Anglo inside you / is as bad as having denied the Indian or Black". A mestizaje of 
linguistic and sexual identity emerges in the borderlands as well: "Cuando vives en la frontera / people walk through you, the wind steals your voice, / you're a burra [donkey], buey [mule], scapegoat / [...] / both woman and man, neither - / a new gender" [...] To live on the borderlands means transgressing the rigid definitions of sexual, racial, and gender definitions". (1995, p. 94-95)

6- "Through our mothers, the culture gave us mixed messages: No voy a dejar que ningún desgraciado maltrate a mis hijos. And in the next breath it would say, La mujer tiene que hacer lo que le diga el hombre. Which was it to be - strong, or submissive, rebellious or conforming?" (ANZALDÚA, 1999, p. 40)

7- "Women are at the botton of the ladder one rung above the devians. The Chicano, mexicano, and some Indian cultures have no tolerance for deviance. Deviance is whatever is condemned by the community. Most societies try to get rid of their deviants. Most cultures have burned and beaten their homosexuals and others who deviate from the sexual common. The queer are the mirror reflecting the heterosexual tribe's fear: being different, being other and therefore lesser, therefore subhuman, in-human, nonhuman". (ANZALDÚA, 1999, p. 40) 


\section{2.a A meio a meio: o sentimento registrado na carne que sofre}

A área da sexualidade humana sempre foi fortemente explorada por muitas teorias. A psicanálise, por exemplo, nasceu dessas explorações e acabou tendo um papel marcante no ocidente, uma vez que ela tentou definir e conceituar a figura feminina, seu corpo e sua função como mulher e sua sexualidade.

Entre tantas outras preocupações, a natureza da sexualidade feminina abriu para a nova teoria do inconsciente, a possibilidade ainda inexplorada de se desvendar a feminilidade e sua constituição. No entanto, o que o inconsciente revela, parece muito próximo do produzido pelo social, pois encontra-se naquele uma normatividade genital e heterossexual bastante parecida com a da família tradicional, ou seja, existem inúmeras regras criando obstáculos para o indivíduo se manifestar como gostaria, ou, como lhe seria mais prazeroso. Sendo assim, as sociedades da modernidade, segundo Anzaldúa, manifestam-se de tal maneira que

\footnotetext{
Se você não se comporta como todos, la gente dirá que você quer ser melhor que os outros, que você se considera o maioral. Com a ambição (condenada na cultura mexicana e valorizada na cultura inglesa) vem a inveja. O respeito carrega consigo um conjunto de regras a fim de que categorias sociais e hierarquias sejam mantidas em ordem: o respeito é guardado pela avó, o papai, o patrão, aqueles com o poder na comunidade. $(1999, \text { p. } 40)^{1}$
}

Dessa forma, a posição de cada um dos sexos está ligada à sua formação corpórea e à sua configuração morfológica, sendo a menina diferente do menino, pois este tem um pênis do qual a menina se sente privada. Diante desta falta, a menina é definida negativamente em relação ao sexo masculino e por isso sente inveja daquele pênis que não tem, e do qual ela não encontra um sucedâneo, a não ser o clitóris. O interior feminino tem e conserva, portanto, seu mistério se comparado ao órgão externo masculino. Ainda segundo Anzaldúa,

Na neblina alaranjada da manhã, o sonolento cantar dos galos vem das árvores. Não vá se desculpar no escuro. Não saia de casa à noite, Prieta, minha mãe diria. Não vá se meter em encrencas por aí. Uma cobra se rastejará por entre suas nádegas, engravidando-a. No frio, elas buscam o calor. Dizem que as cobras gostam de sugar as tetas, podem tirar leite de você. $\left(1999\right.$, p. 47) ${ }^{2}$ 
Tornar-se mulher, nesse sentido, é aceitar não ser homem e para isso a menina empreende um itinerário bastante trabalhoso. Ter acesso a outros benefícios fálicos e à sublimação, ou tornar possível sua evolução como pessoa em funções dessas conquistas, são tarefas que custam caro à menina. $\mathrm{O}$ seu querer parece não coincidir com o seu desejo e, por isso, tudo que ela desenvolve continua sendo insuficiente para explicar, ou, para aceitar a feminilidade. Esta seria, portanto, uma das realidades inapreensíveis do desconhecido de si que a menina deve levar por toda a vida.

Envolta por essas adversidades, a menina nota-se como um "não eu", entidade que atrai outros deslocamentos como a do falo desejado, por exemplo. Se a menina não é toda, se está incompleta, quem ela quer ser, e o quê??

Do ponto de vista das identificações, é desse "não eu" que o Ego tenta prover, a duras penas, o vazio deixado pela falta do falo e que, como uma parte quase despessoalizada, observa a outra parte da qual participa. Ela, então, alucina uma fusão entre uma mãe-alimentar e um pai-ideal e nesse ajuntamento condensa, em última instância, dois em um. Mais uma vez, Anzaldúa afirma:

\footnotetext{
Então, não me dê suas crenças e suas regras. Não me forneça seus deuses mornos. O que eu quero é um relato explicativo das três culturas - a branca, a mexicana, a indígena. Quero a liberdade de esculpir e delinear minha própria face, de estancar a hemorragia com cinzas, modelar meus próprios deuses fora de minhas entranhas. $(1999, \text { p. } 44)^{3}$
}

Naturalmente, então, o objeto (sexual) é, para aquele que o perdeu, alguma coisa que ele mesmo não é, a constituição de uma unidade transportada para um outro espaço, rumo a uma outra mobilidade, outra ação, cujo concreto, interdepende de outras ações para se tornar o receptáculo de uma outra conotação. O que lemos nas afirmações da autora instala seu parecer sobre sexualidade e a escolha sexual feita por ela. Suas palavras nomeiam os fragmentos de si reconhecidos na diferença entre o outro e ela mesma. A partir dessa multiplicidade de possíveis, ela preenche as próprias faltas. 
Um exemplo disso pode ser retirado da seguinte passagem de seu texto:

Havia uma muchacha que morava perto de casa. La gente del pueblo dizia que ela era una de las otras, "dos Outros" [...] Eles chamavam-na meio a meio, mitá y mitá, nem um nem outro mas o estranho duplo [...] Contrariamente a algumas tendências psiquiátricas, os meio a meio não sofrem de confusão sobre identidade sexual, nem mesmo de confusão de gênero. O que estamos sofrendo é de uma dualidade despótica que diz para sermos apenas um e não o outro [...] Mas eu, como outras queers, sou duas num corpo só, ambos, macho e fêmea. $(1999, \text { p. } 41)^{4}$

A intensidade das projeções referencializadas por Anzaldúa nesse espaço vai nos dar a dimensão das forças vivas e caóticas que se debatem para a definição do interno e reunir, também, os fragmentos de fora. Satisfação/decepção, amor/ódio, dentro/fora, são oposições persistentes manifestando a ambivalência fundamental do ser.

Assim sendo, ao invés de proceder rumo à (des)integração do vivido, Anzaldúa revolta-se por não ter a liberdade de se sentir incompleta como deseja. Ela acusa a sociedade de despótica pelo fato desta não aceitá-la como quer ser, a lésbica, a "diferente", em paz. Anzaldúa desconfia que não se nasce nem vazio, nem com o perigo ameaçador da incerteza e imagina os detalhes de seu interior, das partes múltiplas encaixadas idealmente, conforme vai modificando esses encaixes de maneira diferente, caracterizados por atributos e funções específicos.

Com a ajuda de sua rebeldia penetra na vida, e o prazer de Eros instala-se na "fala" de se sentir dupla, duas em uma, multiplicando seus jogos de verificação interno/externo, eu/outro.

Mais do que nunca, Anzaldúa percebe-se como um ser penetrado pelo mundo. Ela gostaria de permanecer no princípio do prazer, mas deve abandoná-lo em função do princípio da realidade. Anzaldúa não é neutra, sente que precisa se definir, traduzir sua inquietude.

Por tudo isso, a tarefa da autora é laboriosa. Sua "imagem" se fixa numa perpétua reintegração entre (des)afetos e bem-estar, sempre uma pulsão vital e uma mortífera, disputando o vencimento da luta, fundamental desde o nascimento. 
Assim é que ela se reconhece: sempre em luta, movimentando-se por entre caminhos hierarquizados que tentam calar seus excessos. Então, embora transtornada, ela consegue chocar mais uma vez:

fiz minha escolha para ser queer (para alguns isso é geneticamente inerente) [...] É um caminho do conhecimento - de conhecimento (e de aprendizado) da história da opressão de nossa raça. É uma forma de equilíbrio, de mitigar dualidades. $(1999, \text { p. } 41)^{5}$

Aqui, Anzaldúa esbarra em um ego que se identifica com uma modalidade de feminino, mas, por outro lado, tende a substituir essa modalidade disciplinando o avesso do Eros demoníaco. Sua feminilidade, ao mesmo tempo que evoca imagens relativas ao conter e ao ser penetrado, também se desvincula das fantasias dessa inclusão e toma o lugar de um outro imaginário. Na falta de amar um homem, a lésbica vai amar um outro ser como ela. Ela é dupla, e dessa modificação, consegue reduzir suas tensões internas. Segundo Kristeva,

\begin{abstract}
Pouco importa o órgão, permanece a confrontação com o poder. Contudo, o paraíso androginal e, de uma outra maneira, os amores lésbicos comportam as ondas deliciosas de uma libido neutralizada, filtrada, desprovida do corte erótico da sexualidade masculina. Toques, carícias, imagens quase indistintas que se misturam umas às outras, se apagam ou se encobrem sem alarde na doçura de uma dissolução, liquefação, fusão ... Tudo isso evoca o diálogo amoroso da mãe grávida com o fruto, mal diferenciado dela mesma, que abriga em seu ventre. Ou o movimento das peles suaves irisadas, não pelo desejo, mas por essa abertura-fechadura, eclosão-fenecimento, entre-dois mal constituído e pronto, já a derreter-se bruscamente num mesmo calor, adormecido ou que desperta no enleio do bebê e da mãe que alimenta. Pele; boca; fenda dos lábios vazia, excitada ou repleta - recobrem esses eflúvios, filtram sua tensão e, fora de toda e qualquer investida agressiva, flutuam, adormentam, drogam. Relaxamento da consciência, sonho diurno, língua nem dialética nem retórica, mas paz ou eclipse: nirvana, embriaguez e silêncio. (1988, p. 103)
\end{abstract}

Isso tudo nos leva a perceber que o olhar tornado, agora, "interior", não vê mais do que o objeto com o qual ele próprio se identifica para suavizar a passagem para o amor, para o outro desejado. Nesse instante frágil, notamos quase a suspensão total da feminilidade, pois esta não é apenas o acontecimento de se ter nascido com o sexo de mulher. Feminilidade é um conceito caracterizado por um conjunto de maneiras emocionais ligadas a afetos e a representações do corpo, tanto quanto ao desejo de gestação e ao desejo de ser possuída como objeto de amor (FREUD, 1981). 
Para a atualização do feminino, o Eu é arrastado para o lado da incerteza de seus limites, para aquilo que foi convencionado, pela psicanálise, ser chamado sexuado ou sexual. Sendo assim, a feminilidade encontra-se vinculada a todo o antes e a todo o depois desses instantes. Nessa relação, Anzaldúa é o bem-estar por ser uma mulher "diferenciada", e a "rebelde" por ter o interior dividido. Ela representa a confusão de um dentro desencadeando as intoleráveis separações.

Para a sociedade machista, ela está do lado do obscuro, é um conteúdo indeterminado porque definiu-se por uma relação amorosa homossexual mesmo precisando enfrentar todas as limitações que lhe foram impostas pela família e pelos machos.

Às custas dessas limitações, Anzaldúa proclama seu medo de voltar para casa, “de ser abandonada pela mãe, a cultura, a Raza, de não ser aceita, estar em falta, ser machucada" [ "of being abandoned by the mother, the culture, la Raza, for being unacceptable, faulty, damaged".] (p. 42).

Na cultura patriarcal, as mulheres são condicionadas a permanecerem no único espaço que os homens determinam, ou seja, converterem-se na serviçal, na escrava de suas luxúrias e até mesmo, como simples objetos de reprodução. Se ela tenta se rebelar contra as ordens determinadas, ter sua liberdade, ela não é aceita.

A autora "grita" mas, paradoxalmente, o seu grito é "visto" apenas como descarga motora. A cultura não lhe opera contribuições de apoio. Pelo contrário, engendra-lhe o silêncio, não lhe responde. Anzaldúa fica machucada, dilacerada, pela resposta não obtida.

Só agora, quando ela "é olhada" com esse outro sofrimento, como a "diferente", a "marcada", é que a cultura responde-lhe para acusá-la de alienígena, representação de uma “diferença”, objeto de projeções imaginárias. E, reciprocamente, Anzaldúa manifesta sua insatisfação "gritando" mais uma vez para se fazer ouvir: 
A mulher não se sente segura quando sua própria cultura, e a cultura do branco, criticam-na; quando os machos de todas as raças caçam-na como presa.

Alienada de sua mãe cultura, "alienígena" na cultura dominante, a mulher de cor não se sente segura dentro de seu mais profundo Self. (1999, p. 42)

Onde, então, deveria Anzaldúa procurar seu porto seguro, sua gratificação em continuar sendo a "outra", a "de cor", mas respeitada por seus valores? De que forma essa mulher poderia reproduzir um outro corpo significativo a fim de equivaler posições únicas na cultura? De acordo com Bhabha,

O "expressivismo" negro reverte a afetividade estereotipada e a sensualidade do estereótipo para sugerir que "as racionalidades são produzidas infinitamente" no modernismo populista. A expressão "nova etnia" é usada por Stuart Hall no contexto negro britânico para criar um discurso da diferença cultural que nunca marca a etnia como a luta contra a "fixação" etnicista e a favor de um discurso mais amplo das minorias que represente sexualidade e classe. (1988, p. 340)

Nesse círculo imaginário, a alternância entre macho e fêmea, entre branco e de cor, tece o fio da paixão que, com seu eterno retorno, produz novamente reforços de ódio e de gratificações sociais. Anzaldúa, então, continua com a possibilidade de ora sentir-se excluída, ora mostrar sua paixão pela "família" chicana, contactar-se com o Outro, tornar-se significativa por ser diferente.

Anzaldúa desafia as forças tradicionais e para excitar sempre mais e mais seus leitores, ela afirma que seus encontros com a cultura, algumas vezes, foram singulares e progressivos, outras vezes, violentos e imediatos. Ela sempre teve o trabalho de reavaliar os conteúdos de sua tradição chicana assim como transpor esses valores de forma transculturalizada.

Em outras palavras, sem interromper seu presente enunciativo, a autora se interroga sobre as relações sociais a fim de introduzir outras "temporalidades espaciais", investigando aqueles imensos territórios que se dimensionam no aquém e no além dos vazios deixados pela linguagem.

Com isso, a imortalidade da história cultural chicana representada na escrita da autora é o preço a pagar e o sacrifício escritural facilmente suportável quando se trata de estabelecer 
relações entre esse e aquele espaço cultural. Anzaldúa aceita, até, carregar esse amor e essa angústia para fixá-los inconscientemente por meio de uma infinidade de representações simbólicas, todas ligadas, que a marcou de forma intensa.

Por isso, ela afirma que uma de suas marcas é a resistência. Ela sente-se perfeitamente livre para se rebelar e para xingar sua cultura, sentir-se imersa nela. ["I feel perfectly free to rebel and to rail against my culture [...] I was totally immersed in mine".] (p. 43).

Podemos reconhecer, dessa forma, que todas essas "falas" de Anzaldúa constatam a amizade e o amor, o ódio e a angústia que ela sente em relação à sua cultura. A autora resiste às ordens de sua cultura, e às ordens hegemônicas do estrangeiro; e morre toda vez que essas mesmas culturas a ignoram e tentam fazê-la desaparecer.

A partir de então, percebemos que Anzaldúa antes de se sentir vazia, retoma seus significados pela escrita (mesmo os mais doloridos), e mostra a vontade de se acalmar e de preservar a vida. Ela reativa a memória e, em forma de resposta imediata à perda, recorre ao próprio momento da perda para ressurgir inteira. Anzaldúa exclama que

\footnotetext{
não glorificarei aqueles aspectos da minha cultura que têm me machucado em nome de me proteger [...] E se ir para casa é negar-me, então eu terei de ficar, e reclamar meu espaço, criar uma nova cultura uma cultura mestiça - com minha própria madeira, meus próprios tijolos e argamassa e minha própria arquitetura feminista. $(1999, \text { p. } 44)^{7}$
}

Vemos assim que, no fundo da dor, está instalado o grito, e, mais uma vez, Anzaldúa lança-o no ar, à sua volta. Então, se o grito é considerado como a primeira ação do ser falante, nada mais lógico do que veicularmos esse grito-ação com a noção de descarga de dominação, para poder resolver com o "grito", a dor sentida. Anzaldúa "grita" para tentar modificar o ambiente "e reclamar meu espaço, criar uma nova cultura" ["then I will have to stand and claim my space, making a new culture"] e tentar obter, assim, a satisfação de suas necessidades: "uma cultura mestiça" [“una cultura mestiza”] (p. 44). 
Dessa forma, o grito já não significa mais uma simples descarga; ele se transformou numa ação específica e agora cumpre o papel de modificar o ambiente e aplacar as tensões internas do sujeito. $\mathrm{O}$ que era um grito descarga passou a ser um grito-ação específico.

Anzaldúa insere-se nesse projeto e cria a cultura mestiça, com "madeira" diferenciada, "tijolos" renovados e "argamassa" mais resistente, todos, numa mistura arquitetada do ponto de vista do feminismo.

Mais do que tudo, os afetos vividos por ela, hoje, são lembranças de experiências passadas cujos símbolos se ligam a vários significantes reproduzíveis em várias direções. Toda essa "materialidade sonora" resulta na sua linguagem, apta a inscrever-se na nossa memória e com a qual a autora preserva o dinamismo de seu pensamento.

Ao contrário de colocar, ou melhor, de situar a linguagem somente na sua posição simbólica, Anzaldúa transforma-a num órgão que não significa, apenas, aquele instrumento prescrito como ferramenta eficaz, mas sim, como aquela "coisa" que prolonga e faz estender o próprio corpo discursivo. A linguagem de Anzaldúa presta-se a uma compreensão mútua, tanto entre os que vivem do lado de lá, quanto entre aqueles que moram do lado de cá da fronteira.

Por meio dessa via de descarga, desse grito transformado em linguagem, Anzaldúa suscita um retorno à intervenção no social e fascina, mais uma vez, pelo tom de seus testemunhos:

Ela espera até que as águas não sejam tão turbulentas e as montanhas tão escorregadias com o granizo. Martelada e ferida ela espera, seus ferimentos levando-a de volta sobre si mesma e sobre o pulso rítmico do feminino. Coatlalopeub espera com ela.

Aqui en la soledad prospera su rebeldia

En la soledad Ella prospera. $(1999, \text { p. } 45)^{8}$ 


\section{NOTAS}

1- "If you don't behave like everyone else, la gente will say that you think you're better than others, que te crees grande. With ambition (condemned in the Mexican culture and valued in the Anglo) comes envy. Respeto carries with it a set of rules so that social categories and hierarchies will be kept in order: respect is reserved for la abuela, papa, el patrón, those with power in the community." (ANZALDÚA, 1999, p. 40)

2- "In the predawn orange haze, the sleepy crowing of roosters atop the trees. No vayas al escusado en lo escuro. Don't go to the outhouse at night, Prieta, my mother would say. No se te vaya a meter algo por allá. A snake will crawl into your nalgas, make you pregnant. They seek warmth in the cold. Dicen que las culebras like to suck chiches, can draw milk out of you." (ANZALDÚA, 1999, p. 47)

3- "So don't give me your tenents and your laws. Don't give me your lukewarm gods. What I want is an accounting with all three cultures - white, Mexican, Indian. I want the freedom to carve and chisel my own face, to staunch the bleeding with ashes, to fashion my own gods out of my entrails".

(ANZALDÚA, 1999, p. 44)

4- "There was a muchacha who lived near my house. La gente del pueblo talked about her being una de las otras, "of the Others" [...] They called her half and half, mita' $y$ mita', neither one nor the other but a strange doubling [...] Contrary to some psychiatric tenets, half and half are not suffering from a confusion of sexual identity, or even from a confusion of gender. What we are suffering from is an absolute despot duality that says we are able to be only one or the other [...] But I, like other queer people, am two in one body, both male and female". (ANZALDÚA, 1999, p. 41)

5- "I made the choice to be queer (for some it is genetically inherent) [...] It is a path of knowledge - one of knowing (and of learning) the history of oppression of our raza. It is a way of balancing, of mitigating duality". (ANZALDÚA, 1999, p. 41)

6- "Woman does not feel safe when her own culture, and white culture, are critical of her; when the males of all races hunt her as prey.

Alienated from her mother culture, "alien" in the dominant culture, the woman of color does not feel safe within the inner life of her Self”. (ANZALDÚA, 1999, p. 42)

7- "I will not glorify those aspects of my culture which have injured me and which have injured me in the name of protecting me [...] And if going home is denied me then I will have to stand and claim my space, making a new culture - una cultura mestiza - with my own lumber, my own bricks and mortar and my own feminist architecture" (ANZALDÚA, 1999, p. 44)

8- "She waits till the waters are not so turbulent and the mountains not so slippery with sleet. Battered and bruised she waits, her bruises throwing her back upon herself and the rhythmic pulse of the feminine. Coatlalopeub waits with her.

Aqui en la soledad prospera su rebeldia

En la soledad Ella prospera". (ANZALDÚA, 1999, p. 45) 


\subsection{A formação de uma outra estrutura: a consciência mestiça}

Narrar as passagens que se alternam em formas de consciência ou de memória requer mudanças na maneira de representar. Podemos nos perguntar se quem escreve na pósmodernidade provoca a perda de um fio narrativo ligando começo, meio e fim, ou se sustenta um tipo de subjetividade completando o sentido dado por outras vozes.

Levando-se em conta que qualquer unidade para ser coerente e dotada de sentido pode ser uma sucessão de acontecimentos transcorridos em linearidade, além de outras fragmentações esperando por conecção a uma nova realidade, as histórias pós-modernas captam um sistema arbitrário de símbolos fragmentados e os ressignificam para formarem novas perspectivas para a representação da realidade.

Sendo assim, o narrador pós-moderno desvenda e também revela um conhecimento que parecia esquecido pelas próprias repressões sofridas, e efetua um trabalho parecido com o de um arqueólogo explorando as profundezas do objeto, a fim de identificar quais figuras promovem tamanho estranhamento e medo para resultar a nova criação.

O discurso de Anzaldúa é um verdadeiro estado de coisas latentes, a espera de serem desvendadas por meio de uma outra linguagem, dispostas criativamente e alertas para explorar possibilidades significativas mais amplas.

Senso assim, no capítulo da obra intitulado "La conciencia de la mestiza / Towards a New Consciousness" (p.99 a 113), a autora dá a ideia de que todo homem tem em si um "outro" homem, quando não muitos deles, constituindo uma nova "realidade", nesse caso, chicana, dúbia e incerta, confundindo os limites entre uma determinada certeza e suas abstrações.

Percebemos que a narrativa da autora, nesse ponto, promove a presentificação de uma problemática entre os mundos ficcional e real e, dessa forma, é como se esse homem visse 
triplicado em si mesmo, todo o medo de pensar sobre aquela "realidade" que comporta não um único "lugar", mas, outros, diferentes corpos, testemunhando novas formas se movendo sozinhas.

Mesmo depois de muitos anos sentindo-se "exilada" em si mesma, Anzaldúa tem seu próprio sistema e apresenta-o nesse capítulo: ama regularizar e regrar sua política sobre práticas (i)legais, religião, participação social e econômica. Ela traz assuntos que incomodam a maioria hegemônica, e luta para sua voz ser aceita nesse espaço que a considera tão multiplicada.

Esse lugar de estranheza se transforma, afinal de contas, em um "duplo". Vemos surgir, assim, uma relação de limites entre "mesmo" e "diferente". É importante observarmos neste capítulo que, se por um lado a autora usa o real para lhe servir de "ponte" transportando seus leitores para o mundo da ficção, por outro, quando percebe que pode haver aspectos de correspondência entre os dois "mundos", ela se questiona sobre a "realidade" da construção criada, e joga com os dois planos.

Anzaldúa coordena sua narração para esses mundos se contrastarem entre si e revelar aquele pertencimento a um além quase inacessível, àquela "coisa" que deixa de existir no momento da escrita, mas que, ao mesmo tempo, está viva e deixa viver. Seus argumentos rumam em direção à "nova consciência mestiça".

Anzaldúa, de fato, encontra-se estreitamente ligada à espacialidade cotidiana, assim como à possibilidade de se referir a uma outra abertura e, nesse caminho pelo qual deve passar, traz de dentro de si as inquietações presentes na palavra de suas personagens, como acontece quando ela comenta que pertence a uma "descendência híbrida, mutável” ["hybrid progeny, a mutable".] (p. 99).

Anzaldúa refere-se à presença da pluralidade das subjetivações que tanto podem desencadear a produção de uma série de representações, quanto a autorepresentação de sujeito 
como portador de uma "fala" sobre a descendência e a(s) identidade(s) chicana(s). Tendo como pano de fundo esse mal-estar vivido por ela mesma, Anzaldúa trabalha com a seguinte focalização:

\begin{abstract}
José Vasconcelos, filósofo mexicano, imaginou uma raça mestiça, uma mescla de raças afins, uma raça de cor - a primeira raça síntese do globo. Ele denominou-a uma raça cósmica, a raça cósmica, a quinta raça envolvendo as quatro maiores raças do mundo. Opondo-se à teoria do ariano puro, e à política da pureza da raça que a América branca pratica, sua teoria é aquela da inclusão. Na confluência de duas ou mais correntes genéticas, com cromossomos constantemente "atravessando", essa mistura de raças, mais do que resultar em um ser inferior, provê uma descendência híbrida, mutável, espécies mais maleáveis com um gene mais rico. Desse cruzamento polinizante racial, ideológico, cultural e biológico, uma conscientização "alienígena" está constantemente em formação - uma nova consciência mestiça, uma consciência de mulher. É uma conscientização das Fronteiras. (1999, p. 99) ${ }^{1}$
\end{abstract}

O fato perturbador das propostas apresentadas por Anzaldúa nessa passagem é a constatação de indicar o duplo papel que o autor pós-moderno tem em relação a si mesmo e em relação ao mundo enquanto sujeito do conhecimento.

Entre tantas mutações e tantas conexões destacando uma série de máscaras que a vida lhe impõe como traço dominante representando o sujeito que escreve, Anzaldúa representa, com essa fala, uma verdadeira revolução atordoando o leitor. Ao narrar com tamanha pluralidade e rapidez os acontecimentos, ela abala de forma constante todas nossas certezas, pois sua voz onisciente não deixa de desdobrar a consciência de si mesma, para apresentar uma personagem narrador imbuída de seu próprio relato. Por esse e tantos outros motivos, Anzaldúa sabe escrever de si mesma e daqueles que compõem o fio da narrativa.

Uma autora como Anzaldúa, então, dá-nos uma produção de estabelecimento de mudanças identitárias ocorridas durante o processo de colonização do México e que estão presentes até a atualidade. Por gerações, os mexicanos têm sofrido um encapsulamento cultural, considerado por muitos, a essência nacional mexicana a ser desvendada por meio das identidades que se apresentam naquele lugar.

Dito de outra forma, Anzaldúa significa, na pós-modernidade, uma voz que tenta determinar o impasse das identidades mescladas, a fim de haver aprovação, por 
reconhecimento de direitos, da nova sociedade chicana que vem se formando sob a ética do multiculturalismo.

A raça cósmica já estaria, assim, sendo reconhecida como possuidora de uma realidade sócio-cultural própria, com seus espaços jurídicos próprios e com políticas culturais e educacionais conscientes.

O sentimento de "identidade" chicana resulta em uma nova cidadania, e provoca, nesse grupo, a discussão de uma normatividade cultural de direitos em que são debatidas as aprovações desta ou daquela reformulação política para os chicanos se adaptarem a uma nova sociedade emergente, e poderem expressar seus valores nesse confronto com os opressores. De acordo com Stavenhagen,

\begin{abstract}
O mestiço, esse personagem que surge nos intervalos da polarizada e rígida estrutura social da colônia, aparece no século XIX como o arauto de uma nova história e é proclamado no XX por José Vasconcelos como a "raça cósmica" cuja luz iluminará a humanidade. De repente, o mestiço que fora depreciado e negligenciado durante o longo período de sua gestação transforma-se no portador das virtudes nacionais, expressão da unidade e da identidade das vibrantes nações latino-americanas. A nova classe média que emerge do antigo regime assume como próprio o mito do mestiço (mito desconstruído por Guilherme de la Peña e outros), que afirma urbis et orbis a homogeneidade e unidade da cultura nacional e estabelece como objetivo das políticas educacionais e culturais a configuração do país mestiço por antonomásia. Neste processo de amálgama necessariamente se deverão perder os extremos: o elitismo crioulo de corte hispanicista - que se destaca com frequiência pelo racismo - e o indianismo restaurador que reivindica a ocupação e possessão originárias da estirpe e repudia toda contaminação com o estrangeiro, o alheio. (2003, p. 39)
\end{abstract}

Os chicanos encontram-se providos, na atualidade, de uma descendência híbrida que os leva a tomar a bandeira de luta por várias causas, além de mostrarem como resistir às políticas que tentam assimilá-los e discriminá-los como cidadãos inferiores, não os reconhecendo no âmbito internacional como "povo", mas que os torna, por isso mesmo, na verdadeira origem da identidade chicana. Mais do que tudo, Anzaldúa tenta resolver esse conflito durante sua existência escritural afirmando que "somos um povo, somos uma gente" ["Somos una gente"] (p. 107).

A disputa para tornar as desigualdades menos gritantes nesse relato imparcial para formação das oposições associadas à sua ancestralidade, não terminou. Anzaldúa denuncia em 
uma crítica crescente às políticas desenvolvimentistas, as imensas desigualdades econômicas e sociais que parecem intensificar as numerosas diferenças nos setores culturais da população indígena há muitos séculos.

Em parte, ela comenta as numerosas falhas nas dinâmicas dos desenvolvimentos culturais que excluem o chicano e, em outra, deixa claro sua preocupação de viver na fronteira, na luta que é empreendida ali, para o reconhecimento de seu povo.

Pelo fato de uma nova conscientização mestiça estar em constante formação, o trabalho de Anzaldúa mostra a força do viver "entrelugares", a necessidade de os chicanos terem duas pátrias como estilo de vida, e o fato de superarem o medo e a vergonha frente aos que determinam a cultura hegemônica. Pelo fato de acreditarem que podem derrotar a intransigência do poder norte-americano, eles têm a total liberdade de surpreenderem positivamente o mundo pelo talento de sua arte, de sua escrita e se enxergarem capacitados para não mais silenciar sua voz.

A energia que lhes permite enfrentar esses acontecimentos como transformação social, é a mesma que emana de cada falante isolado. Ao se juntarem, libertam-se da dominação do Outro e nessa libertação, dialogam entre si e com o resto do mundo, mostrando o caminho de um percurso entre nações.

Para compreendermos esse continuado empreendimento, a situação de viverem entre fronteiras inscreve tanto as heranças coloniais que deslocam limites impostos pela hegemonia, quanto o esforço de (des)construírem, pela escrita, esse mesmo espaço fraturado pelas tradições. Anzaldúa dá a conhecer que os chicanos têm memórias duais articuladas em pensamentos e descobrimentos da própria cultura e que, qualquer movimento para dentro dessas memórias biculturais, inscreve-os no interior de um movimento de ir-e-vir e isto os faz ocupar, sempre, dois lugares ao mesmo tempo.

Por todo esse contexto, Anzaldúa afirma o seguinte: 
Em um constante estado mental nepantilista, uma palavra asteca que significa dilacerado entre caminhos, la mestiza é um produto da transferência dos valores culturais e espirituais, de um grupo para um outro. Sendo tricultural, monolingual, bilíngue, ou multilingual, falar diferente da língua estabelecida, e em um estado de perpétua transição, a mestiza confronta o dilema da espécie misturada: a que coletividade a filha de uma mãe de pele escura ouve? $\left(1999\right.$, p. 100) ${ }^{2}$

Vemos que o caminho seguido pela autora é o de, agora, estender-se ao leitor internacional e incorporar audaciosas tentativas para falar sobre a "nova mestiça".

Ter uma identidade chicana e ser alguém como demonstrou Anzaldúa nesse excerto, é como ser transformado em outras tradições, naquelas geradoras de novos espíritos à espera de promoções sociais durante o processo civilizatório chicano. Suas interrogações e suas respostas podem estar mergulhadas na seguinte pergunta, pois ela aproxima seu pensamento de suas ações: como fazer para que a força propulsora dos chicanos seja reconhecida, pois eles são triculturais, bilíngues e multilinguais? Em outras palavras, como Anzaldúa dialoga com outras "nações" nessa emaranhada transferência do "aqui" para "lá", e vice-versa? Talvez a resposta esteja em um outro testemunho seu, na obra "This bridge we call home”, na qual Anzaldúa afirma o seguinte:

Pontes são entradas para outras realidades, símbolos arquetípicos, primevos, da consciência em mudança. Elas são passagens, condutores que conotam transição, cruzar fronteiras, e mudanças de perspectivas. As pontes teceram entradas liminares, espaços entre mundos, espaços que eu denomino de nepantla, uma palavra Nahuatl referencializando terra entre meio. Transformações ocorrem nesse espaço entre [...] sempre um espaço em transição onde faltam fronteiras claras. Nepantla é terra desconhecida, e viver nessa zona liminar significa estar em um constante estado de deslocamento - um sentimento desconfortável, até mesmo alarmante [...] Mudar é inevitável; nenhuma ponte dura para sempre. $(2002, \text { p. } 1)^{3}$

Em termos de processos históricos que se desenvolvem continuamente, Anzaldúa nos mostra, por essa passagem, a violenta transformação cultural a que os chicanos têm sido submetidos, e cuja consequência é a de estar sempre sobre suas costas, a luta de viver em meio ao caos produzido por tantas outras incertezas.

Sendo assim, ela demonstra como os chicanos precisam ser transformados a todo instante, além de precisarem conviver com o Outro numa terra desconhecida, cheia de 
sentimentos alarmantes. E mais: a tolerância a ser enfrentada sempre que migram para outros paradigmas, permite-lhes desenvolver um novo espírito de pertencimento ao desconhecido, à terra desconhecida, Nepantla.

Por essas diretrizes, a força ideológica demonstra uma identidade chicana e desencadeia motivações a fim de que os chicanos continuem excedendo as fronteiras territoriais e se adaptando às novidades do outro lado da fronteira, a (anti)formadora dos direitos legais.

Anzaldúa adverte que a mestiça precisa caminhar por entre lutas internas, por entre lutas de fronteiras, "sempre em um espaço de perpétua transição" ["in a state of perpetual transition"], assim como se percebe como os "outros que têm ou vivem em mais de uma cultura, nós recebemos múltiplas mensagens, frequentemente opostas" ["Like others having or living in more than one culture, we get multiple, often opposing messages".] (p. 100).

Seu maior argumento, portanto, parece ser aquele de justificar o uso da força da palavra para, em uma só guinada, desferir um golpe duro e certeiro que rompa o controle mantido pela hegemonia norte-americana.

Em consequência, os chicanos, na maioria das vezes, se mostram como a etnia concebida pela linguagem autoral de outras leis, com uma cultura marcada por uma flexibilidade em andamento. Se precisam "viver em duas culturas ao mesmo tempo", se desenvolvem "mensagens opostas e múltiplas", nada mais natural, então, do que determinarem a crença de tornar ineficazes qualquer ação política que queira calar suas vozes. O sujeito do discurso chicano saiu do anonimato e, uma vez mesclado e mestiço, (re)estrutura continuamente as flutuantes significações daquele momento histórico.

Escrever sobre esse assunto, é o mesmo que indicar a possibilidade de deciframento no confronto em busca do significado para a cultura chicana, quem são eles e como vivem. 
A partir de então, Anzaldúa, ciente de seu desdobramento, tem certeza, de sua particularidade em se mover desse espaço para aquele e de sua singularidade em afirmar que duvida da existência de somente algumas diferenças para apontar as diferenças chicanas. Há muito tempo ela sabe que são todos pequenas partes de uma contextura tão maior e disforme que, seu discurso, a cada momento, faz o jogo de encontrar tantas diferenças quantos forem os nós a serem desvendados nos costumes da sociedade.

De fato, ela exprime toda uma diversificada especulação quando passa à fórmula concisa e clara de que se move na universalidade de uma gama de diferenças culturais. Ela faz sua "consciência" alçar voo para apreender outras sustentações no relacionamento com seus irmãos, e afirma que "as possibilidades são numerosas uma vez que decidimos agir e não reagir" ["The possibilities are numerous once we decide to act and not react".] (p. 101).

Sendo assim, o compromisso de Anzaldúa para com sua cultura é a reação à perda da terra tirada pelos norte-americanos, que ela define como uma ação em marcar os traumas sofridos. Sua experiência ao enfrentar essa perda, transforma-a naquela espécie de origem que projeta a alteridade discursiva para fora de si. Segundo Nasio,

\begin{abstract}
A dor (D1) foi tão transformadora que o rastro da sua passagem fica extremamente sensível a novas excitações ou a novos investimentos. A partir de então, a menor impressão poderá fazê-lo reagir. Em resumo, a passagem fulminante da dor da comoção deixou pois dois rastros: a foto do agressor e a excitabilidade dessa foto a todo novo investimento, embora mínimo.

Vamos agora ao presente. Assim sensibilizada, a representação recebe então estimulação pontual e ocasional. Logo que a imagem é reavivada, uma descarga reflexa se produz sob forma de uma nova dor (D2). O sujeito que sofre hoje experimenta pois uma dor (D2), sem com isso estabelecer a menor ligação com o incidente inicial doloroso. (1997, p. 107)
\end{abstract}

As lembranças apresentando as incidências sofridas por Anzaldúa explicam, portanto, as inevitáveis consequências dolorosas e sociais intervindo na gênese de toda sua dor corporal que desaguam, sempre, num outro fenômeno limite, a escolha de tomar novos rumos.

Símbolo das construções nacionais para o estabelecimento de novas identidades chicanas, Anzaldúa representa o momento crucial, o marco que inaugura a formação das bases 
dessa identidade nacional. Conscientizando a sociedade chicana, ela define o que é considerado aceitável do ponto de vista ideológico para marcar a diferença como a parte sempre em atividade, necessária para a formação de suas identidades.

Ela encabeça a tarefa de apresentar o mundo dividido entre "nós" e "eles" e, nesse processo, ajuda a sociedade a perceber os grupos e as classes que formam a "conscientização de sua raça”. Ela conhece e dá a conhecer que identidade e diferença se relacionam de maneira estreita e mostra, em consequência, como a sociedade foi capaz de produzir e de utilizar essas classificações para a produção de posições-de-sujeito.

Ao fixar uma determinada maneira de "tomar outro rumo", Anzaldúa percebe, além do mais, que ao classificar os chicanos "no que somos", questiona também o outro lado da questão, ou seja, "o que não somos”. Isto é, ao tentar normalizar esse binarismo, identifica a instância das relações identitárias construídas, demarcadas por outras oposições binárias do tipo branco/negro, masculino/feminino, heterossexual/homossexual. Ela encontra nesse fundamento, o instante que persiste como pensamento feminino de não calar a voz dentro de si e utiliza-o para fazer valer suas oportunidades de mudanças.

Com isso, ela afirma a necessidade de

\begin{abstract}
A nova mestiça luta para desenvolver uma tolerância por contradições, uma tolerância por ambigüidade. Ela aprende a ser uma indígena na cultura mexicana, a ser mexicana de um ponto de vista inglês. Ela aprende a lograr culturas. A mestiça tem uma personalidade plural - opera num modo pluralístico nada é jogado fora, o bom, o ruim e o feio, nada é rejeitado, nada é abandonado. Ela não sustém apenas contradições, ela transforma a ambivalência em algo mais. $\left(1999\right.$, p. 101) ${ }^{4}$
\end{abstract}

Como podemos observar nesse relato, é por meio do Outro que Anzaldúa se sustenta e deixa correr a fruição serena de julgar a si mesma. Percebemos que sua alma se move ligada aos detalhes das fantasias de outrem, pois ela descobre que, governada pelo desejo "opera num modo pluralístico", ou seja, percebe-se inscrita nas ardilezas da atenção de outrem, e em ser, ela própria, transformada no "outro", no "duplo” dela mesma. 
A partir de então, a Anzaldúa migrante que já tem "consciência" de seu desdobramento, tem certeza, apenas, de sua mobilidade e de sua singularidade. Por outro lado, ao invés de afirmar que duvida de alguma coisa, ela interroga: “o que sei?" Dessa forma e atenta às particularidades de tudo que existe a seu redor, a autora dá início ao desenvolvimento de pensar sobre a diferença, pois somos compostos de tantas fragmentações que perpetramos excessos marcando o informe tão diverso, o jogo das diferentes contradições.

Dessas múltiplas implicações surge uma outra Anzaldúa, trespassada por tantas "representações" das quais se serve a sua linguagem que pode posicioná-la entre o polifônico discurso pós-moderno, tanto quanto no pensamento substancial do dialogismo entre a cultura chicana e a norte-americana. Ela comenta que aprendeu a "lograr culturas", a "ter uma personalidade plural", talvez por "entender" que pode caminhar entre fronteiras, assim como servir-se delas para alcançar seus propósitos.

Fixar, pois, uma determinada identidade em Anzaldúa é o mesmo que tentar solucionar todas essas complexidades de forma coerente, ou seja, é a impossibilidade dos possíveis. A autora explica tendências, modifica os laços, interroga separações para descobrir sua concepção como autora, e como aquela que se transforma cotidianamente.

Anzaldúa assim como a "nova mestiça" é múltipla, é dia e noite, prazer e dor, dentro e fora, macho e fêmea, dupla, enfim, em suas categorias. É hibridização uma vez que se apresenta como presença e ausência, a origem de nenhuma fixidez, uma criatura ligando o passado com as faltas imperdoáveis do presente. Seu código de nacionalidade é ser "uma indígena na cultura mexicana" ["to be an Indian in Mexican culture"], ao mesmo tempo que "ser uma mexicana do ponto de vista inglês" ["to be Mexican from an Anglo point of view"] (p. 101).

A heterogeneidade dos fatos narrados por ela transforma-se em ambivalências de valores permanentes, em um turbilhão de múltiplas identidades acumuladas nas fronteiras de 
um absolutismo hegemônico, numa autonomia chicana centrada na pluralidade do universal. Mais do que uma reflexão nacional, a nova mestiça é um todo político aspirando tornar-se uma "nova consciência mestiça". Para isso, seus limites confrontam novas invenções mescladas de humildade e arrogância, sem deixar, contudo, o furor recolhido da memória histórica, pronta a abordar novas direções, sempre conduzindo a "nova mulher" para a viagem de retorno a si mesma.

Com efeito, depois de tantas perdas, ela afirma que a nova mestiça

pode ser abalada pela ambivalência, por uma intensa e frequente dor, evento emocional que inverte ou resolve a ambivalência. Não tenho certeza exatamente como. O trabalho acontece de forma clandestina - subconscientemente. É o trabalho que a alma realiza. Aquele ponto focado ou central, aquela juntura onde a mestiça se encontra [...] Aquele terceiro elemento é uma nova consciência - uma consciência mestiça - e embora ela seja uma fonte de dor interna, sua energia vem de um movimento criativo continuado que insiste em quebrar o aspecto unitário de cada novo paradigma. $\left(1999\right.$, p. 101-102) ${ }^{5}$

Novamente vemos compensada, nas palavras de Anzaldúa, toda a metamorfose enlouquecedora pela qual ela marca as violências de sua vida. A mestiça "se encontra na juntura da dor e da ambivalência", e, assim, ela atribui-se o desconforto esposado desde a ancestralidade marcando duplamente a decisão que deverá tomar para continuar seduzindo pela palavra, ou gestar uma nova separação, mais gradual e dolorosa que a antiga.

O trabalho da mestiça é um trabalho penoso. Dissociada de algumas medidas morais, mas, associada a outras, ela tenta aplicar a mistura de ritos e leis a seus "irmãos" para que sejam seguidas por todos eles. Deve haver um trabalho fora da banalidade de apenas "falar" sobre a identidade chicana e, nesse processo, a nova mestiça se vê atravessada de tantas paixões que as contradições do consciente se transformam num trabalho "underground subconsciente" a ser resolvido, ela não sabe como. Isto é, a descarga motora não resolve a tensão, e, portanto, as modificações sofridas pela mestiça acontecem de forma ambivalente, sem nenhuma certeza, sempre questionável quanto à sua própria essência. 
Como descarga sonora, o "grito" emitido por Anzaldúa seria aquele de um eco inédito que se inscreve em tantos outros sistemas quantos forem os processos a serem desenvolvidos pela sua memória chicana. De acordo com Nasio, o som emitido por aquele que sofre representa, além de sua dor, a sensação perigosa e agressiva da qual ele mesmo se mune para provocar o outro à sua volta. $\mathrm{O}$ autor acrescenta, ainda, que "nossos gritos sempre uivam a nossa ira por estarmos submetidos aos nossos limites e à nossa fraqueza para superá-los (1997, p. 151).

Dessa forma, desde sua triunfal característica em se perceber múltipla, repetição de um eterno fascínio "gritante" entre liberdade de falar e a vitória de sentir essa liberdade, Anzaldúa comunica sua própria natureza como a virtude voltada para a constituição de várias realidades: sua energia vem de "insistir em quebrar o aspecto unitário de cada novo paradigma".

Com efeito, não basta uma força vital para situar sua linguagem em apenas uma dimensão simbólica. Anzaldúa é aquela que se apresenta construindo pontes que ligam não apenas a materialidade emitida por ela própria, mas que significa, também, a mudança de si mesma no Outro.

Ela ousa multiplicar-se, sublinhar que as antigas esferas hegemônicas localizadas no interior de fazer calar sua voz, já estão politicamente descentradas e sua voz, agora, é global, atingindo qualquer esfera das comunidades mestiças ou não, esperando por aquelas apropriações discursivas das estratégias sociais. Ao provocar esse desequilíbrio, Anzaldúa concebe seu próprio discurso ideológico, de interesse político-social.

Por tudo isso, ao tomar consciência do lugar que ocupa nesse "espaço mestiço", ela dá origem a um exótico elemento social, uma voz estabelecida pela própria soma das experiências vividas, consequência da multiculturalidade propondo um novo modelo de identidade chicana, a "nova mestiça". 
Entendendo toda essa exploração, poderíamos nos perguntar: quem é esse novo grupo étnico? Ou, como é manifestado na linguagem jurídica, quem é esse novo sujeito de direito? Quais outras vertentes democráticas precisariam ser encaradas para que a voz chicana, mestiça desde então, pudesse ser ouvida sem nenhuma outra interdição?

Ao se perceber livre pelo menos na esfera simbólica, Anzaldúa transpõe fronteiras e leva sua voz para além de um jogo ampliado de espelhos. Sua "imago" constitui-se no reflexo que nos obriga a vê-la como o ponto a partir do qual os outros e nós, a vivenciamos como o reposicionamento de toda a cultura chicana, suas identificações coletivas e seus recursos de resistência frente a um discurso hegemônico norte-americano que também não quer se calar.

Repensando o conceito de identidade chicana, vamos encontrá-la redefinindo a territorialidade das comunidades das quais a chicana, inclusive, faz parte, e da qual ela insiste em formar com seu discurso diferenciador.

\section{NOTAS}

1- "José Vasconcelos, Mexicam philosopher, envisaged uma raza mestiza, uma mescla de razas afines, uma raza de color - la primera raza síntesis del globo. He called it a cosmic race, la raza cósmica, a fifth race embracing the four major races of the world. Opposite to the theory of the pure Aryen, and to the policy of racial purity that white America practices, his theory is one of inclusivity. At the confluence of two or more genetic streams, with chromosomes constantly "crossing over", this mixture of races, rather than resulting in an inferior being, provides hybrid progeny, a mutable, more malleable species with a rich gene pool. From this racial, ideological, cultural and biological crosspollinization, an "alien" consciousness is presently in the making - a new mestiza consciousness, una conciencia de mujer. It is a consciousness of the Borderlands". (ANZALDÚA, 1999, p. 99)

2- "In a constant state of mental nepantilism, an Aztec word meaning torn between ways, la mestiza is a product of the transfer of the cultural and spiritual values of one group to another. Being tricultural, monolingual, bilingual, or multilingual, speaking a patois, and in a state of perpetual transition, the mestiza faces the dilemma of the mixed breed: which collectivity does the daughter of a darkskinned mother listen to?" (ANZALDÚA, 1999, p. 100)

3- "Bridges are thresholds to other realities, archetypal, primal symbols of shifting consciousness. They are passageways, conduits, and connectors that connote transitioning, crossing borders, and changing perspectives. Bridges span liminal (threshod) spaces between worlds, spaces I call nepantla, a Nahuatl word meaning tierra entre medio. Transformations occur in this in-between space [...] always-intransition space lacking clear boundaries. Neplanta es tierra desconocida, and living in this liminal zone means being in a constant state of displacement - an uncomfortable, even alarming feeling [...] Change is inevitable; no bridge lasts forever". (ANZALDÚA, 2002, p. 1) 
4- "The new mestiza copes by developing a tolerance for contradictions, a tolerance for ambiguity. She learns to be an Indian in Mexican culture, to be Mexican from an Anglo point of view. She learns to juggle cultures. She has a plural personality, she operates in a pluralistic mode - nothing is thrust out, the good the bad and the ugly, nothing rejected, nothing abandoned. Not only does she sustain contradictions, she turns the ambivalence into something else". (ANZALDÚA, 1999, p. 101)

5- "She can be jarred out of ambivalence by an intense, and often painful, emotional event which inverts or resolves the ambivalence. I'm not sure exactly how. The work takes place underground subconsciously. It is work that the soul performs. That focal point or fulcrum, that juncture where the mestiza stands [...] That third element is a new consciousness - a mestiza consciousness - and though it is a source of intense pain, its energy comes from continual creative motion that keeps breaking down the unitary aspect of each new paradigm”. (ANZALDÚA, 1999, p. 102) 


\section{3.a A eterna passagem: a condição de permanecer mestiça}

Agora vamos redimensionar nossa atenção para outros interesses nesse capítulo escrito por Anzaldúa. Deixar de seguir seus rastros em como constituir-se na nova mestiça, é o mesmo que deixar de testemunhar os elementos autobiográficos com os quais ela compõe a escritura desse fragmento textual.

Dessa forma, situar as histórias da nova mestiça na esfera do reasseguramento da subjetividade mestiça que transpõe fronteiras, é converter seu diálogo no jogo da "encruzilhada", no transpor outras compreensões, a fim de não cessar de inscrever-se e inventar-se em cada domínio poético de suas múltiplas afirmações.

$\mathrm{Na}$ busca do que constitui este "ser" da fronteira, Anzaldúa articula-se na "La encrucijada / The crossroads” (p. 102). Como uma imagem trabalhando com uma outra imagem enquanto raiz do que se transforma em verbal, ela demonstra que é preciso o significante desenhar a palavra e essa articulação ser alcançada no momento em que ela trabalha com os fragmentos de sua fala, para encerrar essa parte da obra.

Por outro lado, aproximando-se mais uma vez do cruzamento de fronteiras, estimulada por continuar na busca de sua identidade, ela afirma que,

\footnotetext{
Como mestiça não tenho país algum, minha pátria expulsou-me, embora todos os países sejam minha terra, sou a irmã de toda mulher ou a amante em potencial. (Como lésbica não tenho raça, meu próprio povo me nega; mas sou todas as raças porque existe o queer de mim em todas elas) [...] Soy un amasamiento, um ato de mistura, de união e encaixe que não produziu apenas a criatura da sombra e a criatura da luz, mas também, aquela que questiona as definições de claro e escuro e lhes concede novos significados. $(1999, \text { p. 102-103) })^{1}$
}

Como ato linguístico, é preciso que decomponhamos essas unidades da fala de Anzaldúa, a fim de relacioná-las ao método decifrador dos sonhos, ou seja, a ausência significativa a ser substancializada pode tornar-se na metonímia articulada representando ora o todo pela parte, ora a parte pelo todo. 
Estabelecendo uma analogia entre o método de interpretação do sonho e o trabalho de Anzaldúa, o que nos permite fazer uma interpretação dessas operações na escrita da autora, é reunirmos as diferentes associações presentes nessa passagem em feixes significativos e darlhes uma ordem, um sentido, pois ela diz estar "amasiada", ao mesmo tempo que é "um ato de mistura, de união e de encaixe" como acontece com o sonho ["I am an act of kneading, of uniting and joining”] (p. 103). No sonho, os fragmentos não apresentam uma posição definida, mas, antes, manifestam-se livremente no seu próprio universo.

Nessa imagem pode ser percebida a busca que a autora empreende na construção de sua mestiça. Como no sonho, a mestiça se apresenta como uma espécie de estrutura escritural diferente de tudo o que se viu até hoje. Estrutura particular, essa escrita é um tipo de elaboração onírica cujas questões propõem o mesmo tipo de fragmentação do conteúdo do sonho. Em cada um dos fragmentos propostos no capítulo, há uma lembrança, um fato qualquer que estabelece uma certa relação com aquilo narrado por Anzaldúa (e a mestiça). A autora cria e estabelece uma gramática que ora se apresenta agramatical, ora operando como um vocabulário dessa mesma gramática, todos, enfim, reunidos na nova curiosidade, o híbrido, os encaixes, o amasiamento.

Ora, existem determinados momentos durante o desenvolvimento do capítulo que parecem demonstrar uma falta de complementaridade entre significante e significado, transferindo a existência do sujeito escritural para outra condição significante. Dito de outra forma, a "mestiça autora" é a "criatura da sombra e da luz" ["both a creature of darkness and a creature of light"], e também aquela que "questiona definições" ["that questions the definitions”] (p. 103). Ela nos faz acreditar que se trata exatamente de relacionarmos um conteúdo latente com o vivido por ela em épocas mais distantes, tanto quanto relacionarmos o vivido na contemporaneidade pós-moderna com o empreendimento de seu trabalho nesse trecho. 
Para Anzaldúa, o relato desse "desconhecido" transforma-se na cena cuja existência dá a conhecer a pergunta sobre a recordação do momento que lhe aparece. Se ela nos concede novos significados, é por conta daquelas fantasias construídas das pequenas lembranças infantis que, agora, despontam para marcar-lhe a fala sobre a nova mestiça.

Nesse contato, Anzaldúa apresenta uma continuidade sintagmática do verso, a incidência intermitente que cria a sincronicidade entre lembranças do passado e elementos do presente. Seu trabalho de reconstruir a mestiça é aquele de re-significar um passado pleno de imagens. Ela monta a memória da ancestralidade e por meio dela, avança sua escritura em um ir-e-vir permanente, transportando-nos por entre as fronteiras de sua memória histórica.

Anzaldúa deixa de ser individual a partir do gesto da escrita para se transformar naquele pensamento plural do qual ela é a fidelidade narrativa. Segundo Bhabha,

\begin{abstract}
É precisamente na leitura entre as fronteiras do espaço-nação que podemos ver como o conceito de "povo" emerge dentro de uma série de discursos como um movimento narrativo duplo. O conceito de povo não se refere simplesmente a eventos históricos ou a componentes de um corpo político patriótico. Ele é também uma complexa estratégia retórica de referência social: sua alegação de ser representativo provoca uma crise dentro do processo de significação e interpelação discursiva. Temos então um território conceitual disputado, onde o povo tem de ser pensado num tempo-duplo; o povo consiste em "objetos" históricos de uma pedagogia nacionalista, que atribui ao discurso uma autoridade que se baseia no preestabelecido ou na origem histórica constituída no passado; o povo consiste também em "sujeitos" de um processo de significação que deve obliterar qualquer presença anterior ou imaginária do povo-nação para demonstrar os princípios prodigiosos, vivos, do povo como contemporaneidade, como aquele signo do presente através do qual a vida nacional é redimida e reiterada como um processo reprodutivo. (1998, p. 206-207)
\end{abstract}

Tudo o que temos a considerar, portanto, é o movimento do poder interior de Anzaldúa dando a conhecer toda a ideologia dos chicanos: eles devem se constituir novamente em um "sujeito nacional", donos de um discurso nacional, muito embora sentindose estruturados dentro de uma articulação de diferenças.

Pelo discurso ideológico da autora apresentado nessa encruzilhada, nós nos percebemos examinando tantas outras vulnerabilidades histórico-sociais, que não se torna estranha sua recriação enquanto cultura, uma vez que os chicanos encontram-se diante da 
insuportável ideia de desintegração social. Ao invés da temporalidade única de lugar, vemos surgir a divisão da heterogeneidade de sua população.

O povo que passou a ser identificado pelo discurso de Anzaldúa como aquele movimento significante pronto a produzir a imagem da diversidade espaciotemporal, pode ser percebido, dessa forma, como o (des)equilíbrio significativo dos fatos sociais, embasado por diferentes elementos (des)coordenados e mantidos por uma linguagem subjetivada, compondo a "nova conscientização".

Nesse ato presente, Anzaldúa toma uma posição dialética de continuar se questionando sobre o caminho de sua "nova mestiça", e sugere que o

primeiro passo dela é fazer um inventário. Despojando, desgranando, quitando paja. Apenas o que ela herdou de seus ancestrais? Este peso sobre as costas - que é a bagagem da mãe indígena, a bagagem do pai espanhol, aquela do anglo?

Pero es difícil diferenciar entre lo heredado, lo adquirido, lo impuesto [...] este passo é uma ruptura consciente com todas as tradições opressivas de todas as culturas e religiões [...] Ela adota novas perspectivas para os de pele escura, as mulheres e os queers [...] Desconstrói, constrói. Ela torna-se uma nahual, apta a transformar-se numa árvore, num coiote, numa outra pessoa. Ela aprende a transformar o pequeno "eu" no Self total. Se hace moldeadora de su alma. Según la concepción que tiene de si misma, así será. (1999, p. 104-105)

Mais uma vez, a partir dessa característica discursiva fragmentária, Anzaldúa marca o realismo e o estereótipo a que se deixam envolver os chicanos nessa zona de instabilidade sócio-cultural. Cada vez que ela torna imperativo questionar-se a respeito da história chicana, a autora mostra o progressivo processo de constituição identitário, assim como o processo de perda da identidade por meio do qual os chicanos tendem (re)significar uma identificação cultural. Ganho e perda, eis a ambivalência a que está submetida a etnia nesse movimento flutuante, longe de qualquer certeza pós-colonial, questionando sobre passado e presente.

Anzaldúa afirma que "é difícil diferenciar entre o herdado, o adquirido, o imposto", e nesse espaço de heterogeneidades fronteiriças, a etnia não tem como aceitar uma cultura própria, a não ser aquela marcada por uma sucessão de plurais [“Pero es difícil differentiating between lo heredado, lo adquirido, lo impuesto".] (p. 104). O fato de os acontecimentos 
virem de todo local faz a mestiça adotar "novas perspectivas", e se revelar emergente para originar uma nova referência. Esse movimento de entrelugar es, portanto, marca e ao mesmo tempo suplementa a natureza disjuntiva do vazio cultural deixado pelo passado histórico.

Mais do que qualquer contradição, a passagem acima insinua uma meditação sobre a formação do tempo e do espaço chicanos, a partir dos quais a narrativa sobre os mesmos deve continuar suas referências.

E, por meio destas, a autora interrompe e fragmenta a linearidade narrativa mais uma vez, quando refere-se a uma outra singularidade histórica, desta feita, discutindo sobre o valor que a mulher não tem, dentro da sociedade chicana. Ela afirma o seguinte:

\author{
"Você não serve para nada- \\ você é boa para nada \\ É só uma velha."
}

\begin{abstract}
"Você é nada exceto uma mulher", significa que você é defeituosa. Seu oposto é ser um macho. O significado moderno da palavra "machismo", assim como o conceito, é, na verdade, uma invenção inglesa. Para homens como meu pai, ser "macho" significava ser forte para proteger e sustentar minha mãe e nós, além de ser capaz de mostrar amor. O macho de hoje duvida de sua habilidade em alimentar e proteger sua família. Seu "machismo" é uma adaptação da opressão, da pobreza e da baixa-estima. É o resultado da dominação hierárquica do macho. $(1999, \text { p. 105) })^{3}$
\end{abstract}

Como vemos, tem sido grande o esforço de Anzaldúa em apontar as condições sóciopolítico-culturais que certas camadas da sociedade sofrem quando são discriminadas e relegadas à marginalidade, como acontece com as mulheres chicanas.

A demolição do status social dessas camadas aparece clara e radical por entre as histórias narradas nesses fragmentos. A mulher significa nada, aberta a toda sorte de diferenças quantos forem os possíveis julgamentos recriminatórios sobre ela. Sentindo-se inclusive desconhecida para si mesma, a mulher deixa sua existência no limite de seu interior e da exterioridade masculina.

Sua fragilidade está coberta pelo véu permanente da tensão vivida entre os dois mundos - o seu e o do macho. Nessa sociedade, a mulher é considerada aquele algo 
diferenciador cuja necessidade submete-a às situações massificantes do poder do outro. E esse poder do macho, hoje, ao invés de suprir a fêmea como acontecia no passado, tem se transformado no opressor da figura feminina. Sem nenhum privilégio, a mulher existe, apenas, enquanto cativa da "dominação hierárquica do macho" ["It is the result of hierarchical male dominance".] (p. 105).

As cenas presentes nesses testemunhos mostram, dessa forma, o quão difícil é a vida da mulher mestiça e seu ofício, o quanto esses encontros entre submissão e rebeldia femininas se apresentam desde sempre, dentro de uma determinada sociedade, senão em todas elas, e o quanto essas mulheres têm lutado para mudar esse cenário. Mais do que se converter em coisa incerta e passageira, a luta da mestiça tem se transformado naquelas renegociações que produzem uma tênue solidez sociológica.

É, portanto, nesse espaço de duplicação que Anzaldúa continua seu testemunho. Segundo ela,

\begin{abstract}
A luta da mestiça é, acima de tudo, uma luta feminista. Enquanto os homens pensarem que precisam xingar as mulheres e entre si para serem homens, enquanto forem ensinados que são superiores e, portanto, culturalmente favorecidos sobre as mulheres, enquanto ser velha for algo desprezível, não pode haver uma cura real de nossa psique. $\left(1999\right.$, p. 106) ${ }^{4}$
\end{abstract}

Dessa forma, durante esses vários momentos confessionais, notamos o desespero de Anzaldúa em tentar recuperar a dignidade sócio-cultural feminina, bandeira que a mestiça foi eleita para carregar. Na encruzilhada das fronteiras, vemos o conceito de mulher-de-cor ser transformado em um contraste de sombras no qual ela parece estar mergulhada. Isto é, a narratividade apresentada acima nos remete para uma indeterminação feminina de onde os machos, pela cultura, algemam as mulheres à sua submissão. Suas vidas passam a pré-existir à vontade anterior do macho e as mulheres de cor começam a ser olhadas de toda parte nesse espetáculo como o encontro do caminho da submissão imposto pela sociedade machista, "culturalmente favorecida". 
Sendo assim, a mulher de cor tenta traçar seu próprio destino e não se limita ao que a consciência masculina lhe impõe. Ao contrário, ela continua como minorias que lutam, tentando livrarem-se do estigma de ser "velha e desprezível”, de ser simplesmente mulher.

É desse interior feminino que vem a vibração, a ressonância desencadeante da separação entre a mulher chicana do passado e a "nova consciência mestiça". Mais do que o tato indispensável para exprimir a euforia subtraída dessa confusão, a mulher de cor dispõe, assim, daquele abismo inquietante a lhe promover novas relações de convergências ligadas aos contratempos da incerteza da atualidade, mas que, ao mesmo tempo, lhe oferece um retorno para ser ouvida em todo o mundo. Segundo Bhabha,

É desta incomensurabilidade em meio ao cotidiano que a nação fala sua narrativa disjuntiva. Das margens da modernidade, nos extremos insuperáveis do contar histórias, encontramos a questão da diferença cultural como a perplexidade de viver, e escrever, a nação. (1998, p. 227)

Dessa forma, Anzaldúa sofre com sua identidade mal definida. Ela é homossexual, mas há momentos que precisa se disfarçar com outras roupas, de mulher, se quiser que seu discurso seja aceito e espalhado nessa imensa sociedade machista, e se assim acontece, isso é motivo para ela se preocupar. Seus amores são infelizes (ela já anunciou que não se casaria com um homem e o fato, na sua sociedade, não é aceito); suas namoradas são mistério, e por causa delas, parece persistir em Anzaldúa, essa forma indefinida.

Tudo isso resulta naquele tipo de afeto que se apresenta como o vínculo resgatado do vivido, dos dados sensoriais e das palavras, em direção ao pensamento que os exprimem. A modificação dos laços experienciados por Anzaldúa, os sofrimentos resultantes das separações, a descoberta de novas experiências, concretizam-se, então, em termos de outra fala, outra comunicação, sem, contudo, desconectarem-se no interior de seu próprio self. Dessa forma, ela exprime o seguinte: 
Eu acho que precisamos permitir aos brancos serem nossos aliados. Por meio de nossa literatura, arte, corridos, das fábulas, precisamos dividir nossa história com eles para que, quando instalarem comitês para ajudar os Navajos da Big Mountain, ou os fazendeiros chicanos, ou os Nicaraguenses, eles não possam ignorar as pessoas por causa de seus medos raciais e ignorâncias. Virão para ver que não estão nos ajudando, mas seguindo nossa liderança. (1999, p. 107)

Para criar essa situação, Anzaldúa precisou passar por fronteiras de sensações, de posse de um discurso próprio, de palavras para que seu bem-estar social tivesse êxito depois da morte do desconforto da diferenciação. Nesse dentro/fora confuso, sofrido, desejante, seu discurso permanece impermeável à hegemonia do Norte e pede por aliança, e não por submissão.

Como um desejo vivo e diferente, sua fala, nesse fragmento, espanta a existência de uma sincronia da memória, e, supostamente, permite que os brancos sejam seus aliados. Por outro lado, a autora quase não consegue compreender porque os brancos têm tanto medo dos chicanos, e porque são tão arrogantes. Ela constrói com a ajuda do locus do Outro, todo o discurso dessas diferenças e transfere para as fronteiras, o espaço significativo dessa espacialização subalterna, pronto a incitar o pensamento sobre si mesma, para contestar a submissão.

Anzaldúa percebe que precisa manter abertas todas as discussões acerca das culturas cumulativas de ancestralidade como a sua e, de novo, encara sua história como o objeto a ser apropriado pelo resto da população. Para a autora, é muito mais interessante ser símbolo da passagem atravessada por espaços culturais, do que permanecer estanque e não ser encarada como símbolo de mudanças.

Essas novas formas ativistas de inflamar a sociedade para se articular pelos próprios direitos, sempre estiveram presentes na linguagem de Anzaldúa. Ela sugere que as mudanças sociais estão todas constituídas no próprio ato de sua enunciação discursiva e que o conteúdo disposto aí é o da multiplicidade significativa, convidando os chicanos a participarem dos novos acontecimentos históricos, resultantes de tantas outras modificações. 
Seja como for, Anzaldúa não nega as diferentes conexões que se fazem necessárias para que ela leve adiante os efeitos resultantes dessa nova forma cultural, a nova consciência mestiça. Ela consegue personificar as metáforas de sua linguagem por meio de sua argumentação. Ela altera toda uma forma de pensamento social e, nesse limiar, os tempos e os espaços de sua representação social mostram-se como sujeitos de uma outra diversidade cultural, pacientes múltiplos daquelas emaranhadas desarmonias étnicas, ou seja, por meio delas, Anzaldúa multiplica o arco-íris de suas próprias associações e retorna, sempre, ao processo de reconstrução de sua identidade chicana.

Para falar sobre essa situação, a autora afirma que "a cultura branca dominante está nos matando vagarosamente com sua ignorância [...] A ignorância divide as pessoas, cria preconceitos. Um povo mal informado é um povo subjugado" ["The dominant white culture is killing us slowly with its ignorance [...] Ignorance splits people, creates prejudices. A misinformed people is a subjugated people".] (1999, p. 108).

Este pensamento objetivista muda a exploração e a teorização sobre a diferença social com a qual Anzaldúa está acostumada. Ao considerar sua construção enunciativa, as palavras a empreenderem uma mudança de paradigmas suplantando o modo mais antigo de submissão, Anzaldúa propõe que a nova identidade chicana seja aquela das "novas imagens de identidade, novas crenças sobre nós mesmos, nossa humanidade e valor sem mais questionamento" ["new images of identity, new beliefs about ourselves, our humanity and worth no longer in question".] (1999, p.109).

O próprio objeto de representação de Anzaldúa, a construção da nova consciência mestiça, significa que não são apenas seus propósitos sociais e políticos que especificam suas experiências como tal. Ela se apodera de uma representação que nunca foi socialmente inocente e por meio dessa mudança, deixa claro que o elemento de imprevisibilidade altera a "verdade" sobre a história chicana, e demonstra que viver na fronteira é exaustivo, 
imprevisível; os movimentos de trocas transculturais não cessam e, entre uma coisa e outra, as relações sociais estão sempre mudando, às vezes até sem tempo de se poder assimilar um novo jeito de ser. A forma como essas mudanças ocorrem é aquela de se posicionar como sujeito discursivo e construir a nova consciência mestiça.

Por tudo isso, ela exclama:

Estamos vivendo na noite da Raça, um tempo quando se trabalha em silêncio, no escuro. $O$ dia em que aceitamos isso e como somos e para onde vamos e por quê - esse será o dia da Raça. Tenho o compromisso de expressar minha visão, minha sensibilidade, minha percepção da revalidação do povo mexicano, seu mérito, estima, honra, apreço, e seu valor. $\left(1999\right.$, p. 109-110) ${ }^{6}$

Como vemos, o testemunho tornou-se, para Anzaldúa, o lugar privilegiado de sua afirmação crítica, o aparato capaz de refigurar seu próprio discurso. O discurso da autora, nessa citação, tem o compromisso de expressar sua visão, sua nova prática política, o chamamento do mundo para ver os méritos dos chicanos, sua honra, seu valor.

O excerto acima produz ou reproduz a posse do segredo chicano e o que se deve fazer com esse mesmo segredo, a fim de ele ensinar como não ser totalmente dominado pela hegemonia estrangeira, "um tempo quando se trabalha em silêncio, no escuro" ["un tiempo cuando el trabajo se hace a lo quieto, en lo oscuro"]. Viver "na noite da Raça" ["viviendo en la noche de la Raza"], no entremeio de se "trabalhar em silêncio, no escuro", e no "dia em que aceitamos isso", representa responder a uma questão antiga de silenciamento à qual o chicano não quer mais ficar refém [“El día cuando aceptamos tal y como somos”.] (p. 109).

Ao contrário, dessa condição, o que parece ser a dor de cada um deles é o não reconhecimento de sua identidade. Para cada chicano, uma palavra nomeando o seu reconhecimento como o "ser gente", é o instante da livre utilização de se dizer "sou chicano, sou da Raza”; o momento de dizerem que o resultado dessa criação significa que fabricaram os elementos de transcendência no contexto de suas relações culturais e sociais. 
Assim, um dos aspectos notáveis desse reconhecimento é a escolha do dia 2 de dezembro para celebrar

o dia da chicana e do chicano. Neste dia limpo meus altares, acendo minha vela a Coatlalopeub, [...] Neste dia declaro quem somos [...] procuro por nossa dignidade essencial como povo, um povo com um propósito - pertencer e contribuir para alguma coisa maior do que nosso povo. Neste dia, procuro recuperar-me e remodelar minha identidade espiritual. Anime-se, Raça, a celebrar o dia da chicana! $(1999, \text { p. } 110)^{7}$

O que, então, pode sentir essa mulher para reivindicar com tanta insistência a fecundidade e o nascimento da Raça? O que teme ela da perene fertilidade feminina para parecer arrastar-se por entre a contramão de um discurso hegemônico?

Anzaldúa multiplica suas ideologias para saudar o dia 2 de dezembro como o dia da/o chicana/o. Ela escapa dos movimentos internos que a tornam acessível a uma única participação, e compensa a ausência do objeto desejado (ter uma identidade chicana) com um discurso feminista representando, ao mesmo tempo, o pensamento interior e exterior de todo um contingente racial, a nova consciência mestiça. São inevitáveis, portanto, essas suas oposições, assim como são inevitáveis todos seus movimentos em direção à desestabilização de categorias unitárias.

Esse dia é, como vemos, um investimento. É uma problemática particular cuja metáfora adere ao corpo feminino. O dia 2 de dezembro representa, sem dúvida, a particularidade feminina de associar esse dia ao seio alucinado pelo bebê. O momento da posse constitui a maneira particular, a forma metafórica do inconsciente possuindo o objeto.

Sendo assim, Anzaldúa deseja ter uma identidade chicana que passa a "possuir" o dia 2 de dezembro como a constituição de si mesma, ou seja, de sua identidade. Com isso, ela consegue satisfazer-se e à Raza pelos seus próprios meios e alucina o mesmo prazer na relação mãe/bebê no ato de mamar. A partir de então, mantém-se sempre nessa relação dual de ser chicana/ser espiritual, de ser "dupla" em si mesma, a "sombra da Besta". 
Durante o dia dois de dezembro, ela procura recuperar-se e remodelar sua identidade, além de animar a Raza à ação, pedindo para que ela se manifeste: “Anima-te!” Temos aí, então, o fato de sua palavra fazer emergir a construção de um multiculturalismo, de onde a Raza surge perfeita, vitoriosa, como sonhada por Anzaldúa.

Devido a esse modo de manifestação, percebemos o quanto a autora se preocupa com uma identidade, pois, mais uma vez, vamos encontrá-la de volta à terra natal, à terra por meio da qual ela espera ter sua identidade celebrada, e da qual ela tem as mais diversificadas lembranças.

Anzaldúa manifesta-se da seguinte forma sobre a terra natal:

Voltei. Custou-me tanta dor este afastamento [...] Terra natal". Isto é lar, as pequenas vilas no Vale, os povoados [...] Ainda sinto o velho desespero quando vejo as casas sem pintura [...] Como amo este trágico vale no Sul do Texas [...] esta fronteira entre os Nueces e o Rio Grande. $(1999$, p. 111-112)

Desde sua mais remota alusão à terra perdida, a autora apresenta-se tão diversa para falar sobre a terra natal que o fragmento mencionado acima indica que essa volta ao lar, aos costumes e aos encontros do passado, acontecem de uma forma ou de outra. A autora nunca hesitou em declarar que gostaria de ter de volta o antigo lar, mesmo sendo ela a mais curiosa das estranhas, morando em terras alheias. Ela confessa, assim, mais uma vez, a necessidade de ultrapassar fronteiras para que, metamorfoseada, possa voltar e desempenhar seu papel de supremacia chicana sem, contudo, apagar as distinções entre ela e o Outro.

Anzaldúa é amiga do diálogo e assim se apresenta a todos. Com a palavra, ela promove a retórica que, como os grandes viajantes, constrói a nação chicana. Mesmo sentindo na carne nenhum tipo de benevolência por parte do poder hegemônico, a autora viaja em si mesma e explora outras paragens. Esforça-se e volta para confessar o quanto foi dolorosa a separação de sua terra por tanto tempo. 
Reconhece que sua missão é múltipla: precisa dirigir-se a um público bem mais numeroso que antes e quer orientar os "irmãos" sobre seus direitos. Ela pretende direcionar a constituição da nova consciência mestiça e também gosta de ser dupla. Além de tudo isso, a autora exagera em sua diversidade cultural.

Sem dúvida, Anzaldúa já começa "reestruturando" sua cultura em proveito de uma reintegração universal. Sua ancestralidade serve-lhe de base para que, a partir daí, ela possa considerar e condenar todas as outras virtudes alojadas no "corpo" chicano. Dessa forma, toda e qualquer fronteira pode ser considerada como porta de entrada para seu discurso diferenciador.

Ignorando certas tendências, mas abraçando outras, Anzaldúa segue no seu despertar para as novas realidades e adverte a todos que, o caminho na pós-modernidade, é esse: o de "ligamento" entre "isso" e "aquilo", entre a "coisa" e a "palavra", e finaliza com o seguinte:

Sim, o chicano e a chicana sempre tomaram conta do crescimento das coisas e da terra. Novamente vejo nós quatro, crianças, descendo do ônibus escolar, vestindo nossas roupas de trabalho, indo para o campo com papai e mamãe, todos os seis curvando-se sobre o chão. Sob nossos pés, sob a terra jaziam as sementes de melancia [...] Fazíamos colheitas [...] Crescimento, morte, decadência, nascimento. O solo preparado novamente, fertilizado, trabalhado. Uma constante mudança de formas, renascimentos da terra mãe.

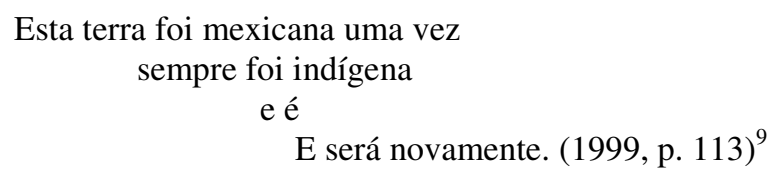

\section{NOTAS}

1- "As a mestiza I have no country, my homeland cast me out; yet all countries are mine because I am every woman's sister or potential lover. (As a lesbian I have no race, my own people disclaim me; but I am all races because there is the queer of me in all races.) [...] Soy un amasamiento, I am an act of kneading, of uniting and joining that not only has produced both a creature of darkness and a creature of light, but also a creature that questions the definitions of light and dark and gives them new meanings". (ANZALDÚA, 1999, p. 103)

2- "Her first step is to take inventory. Despojando, desgranando, quitando paja. Just what did she inherit from her ancestors? This weight on her back - which is the baggage from the Indian mother, which the baggage from the Spanish father, which the baggage from the Anglo?

Pero es difícil differentiating between lo heredado, lo adquirido, lo impuesto [...] This step is a conscious rupture with all oppressive traditions of all cultures and religions [...] She adopts new perspectives toward the darkskinned, women and queers [...] Deconstruct, construct. She becomes a 
nahual able to tranform herself into a tree, a coyote, into another person. She learns to transform the small "I" into the total Self. Se hace moldeadora de su alma.Según la concepción que tiene de si mísma, así será”. (ANZALDÚA, 1999, p. 104-105)

3- "Tú no sirves pa'nada - / You're good for nothing. Eres pura vieja." "You're nothing but a woman" means you are defective. Its opposite is to be un macho. The modern meaning of the word "machismo", as well as the concept, is actually an Anglo invention. For men like my father, being "macho" meant being strong enough to protect and support my mother and us, yet being able to show love. Today's macho has doubts about his ability to feed and protect his family. His "machismo" is an adaptation to oppression and poverty and low self-esteem. It is the result of hierarchical male dominance". (ANZALDÚA, 1999, p. 105)

4- "The struggle of the mestiza is above all a feminist one. As long as los hombres think they have to chingar mujeres and each other to be men, as long as men are taught that they are superior and therefore culturally favored over la mujer, as long as to be a vieja is a thing of derision, there can be no real healing of our psyches". (ANZALDÚA, 1999, p. 106)

5- "I think we need to allow whites to be our allies. Through our literature, art, corridos, and folktales we must share our history with them so when they set up commitees to help Big Mountain Navajos or the Chicano farmworkers or los Nicaraguenses they won't turn people away because of their racial fears and ignorances. They will come to see that they are not helping us but following our lead". (ANZALDÚA, 1999, p. 107)

6- "Estamos viviendo en la noche de la Raza, un tiempo cuando el trabajo se hace a lo quieto, en lo oscuro. El día cuando aceptamos tal y como somos y para donde vamos y porque - ese día será el día de la Raza.Yo tengo el compromiso de expresarmi visión, mi sensibilidad, mi percepción de la revalidación de la gente mexicana, su mérito, estimación, honra, aprecio, y validez". (ANZALDÚA, 1999, p. 109-110)

7- " "el día de la Chicana y el Chicano. On that day I clean my altars, light my Coatlalopeub candle [...] On that day I affirm who we are [...] On that day, I search for our essential dignity as a people, a people with a sense of purpose - to belong and contribute to something greater than our pueblo. On that day I seek to recover and reshape my spiritual identity. Anímate! Raza, a celebrar el día de la Chicana". (ANZALDÚA, 1999, p. 110)

8- "I have come back. Tanto dolor me costó el alejamiento [...] Tierra natal. This is home, the small towns in the Valley, los pueblitos ... I still feel the old despair when I look at the unpainted houses [...] How I love this tragic valley of South Texas ... this borderland between the Nueves and the Rio Grande". (ANZALDÚA, 1999, 111-112)

9- "Yes, the Chicano and Chicana have always taken care of growing things and the land. Again I see the four of us kids getting off the school bus, changing into our work clothes, walking into the field with Papi and Mami, all six of us bending to the ground. Below our feet, under the earth lie the watermelon seeds [...] We harvest them [...] Growth, death, decay, birth. The soil prepared again and again, impregnated, worked on. A constant changing of forms, renacimientos de la tierra madre.

This land was Mexican once

was Indian always

and is.

And will be again”. (ANZALDÚA, 1999, 113) 


\section{GUILLERMO GÓMEZ-PEÑA}

Nasceu em 1955 e se criou na Cidade do México. Foi para os Estados Unidos em 1978 como artista performático e escritor e estabeleceu-se em San Francisco onde é o diretor artístico da La Pocha Nostra (uma de suas "vozes" dentro de uma multiplicidade de subjetivações). Como estratégia performática, La Pocha Nostra é conduzida por uma série de intervenções na esfera pública de Detroit.

Seu trabalho pioneiro chama a atenção por empregar comentários políticos, material autobiográfico, provocação performativa, política da linguagem, vídeo, rádio, instalação de telões, poesia, jornalismo e teoria cultural.

Suas performances ironizando a visão norte-americana da cultura latina incluem o simulacro de uma intervenção-pirata em uma estação de TV, transmitida ao vivo para os Estados Unidos pela Paper Tiger TV (um canal de TV comunitária), o "Virtual Reality Sombrero" (uma ironia sobre os capacetes de alta tecnologia usados nos experimentos de Realidade Virtual), e o "Ciber-Bandana" (em que o lenço de cabeça funciona como uma ironia dos aparatos de navegação no ciberespaço).

Outra de suas famosas performances são as "confissões". Guillermo e Roberto Sifuentes ficam expostos durante horas em vitrines de vidro, e o público é convidado a comentar sobre sua visão da cultura mexicana, e da influência latina. Eles apresentam alguns trechos dessas confissões que incluem de fantasias sexuais, interesses culturais e curiosidades diversas, a preconceitos, distorções e agressividade. Gómez-Peña já publicou também as seguintes obras:

\section{LIVROS:}

Warrior for Gringostroika (Graywolf Press, 1993) ISBN 1-55597 - 199 - 7; Dangerous Border Crossers (Routledge, 2000); Codex Espangliensis (City Lights, 2000) ISBN 9780872863675; Ethno-techno (Routledge, 2004); El Mexterminator (Oceano, 2005) Spanish; Bitacora del Cruce (Fondo de Cultura Economica, 2006) Spanish and Spanglish.

\section{VÍDEOS:}

Border Clasicos (uma antologia de todos os seus trabalhos em vídeo, 1988-2008, Vídeo Data Bank)

Homo Fronterizus (uma coleção com suas colaborações produzidas com o diretor cinematográfico Gustavo Vazquez, 2008). 


\section{CAPÍTULO III}

\section{5- O espaço presente na arte performática de Guillermo Gómez-Peña}

Guillermo Gómez-Peña surpreende-nos com uma espécie de rapsódia e usa técnicas de montagem nas quais aparecem no mesmo espaço poema, ensaio, cartas, textos performáticos, crônicas, textos transmitidos via rádio, resultando em formas de deslocamento e inversão que dão a ideia de um verdadeiro mosaico construído por movimentos migratórios. Estas produções foram escritas no período de 1985 a 1995 e ele inventa e molda originalidades que ligam o passado do povo asteca ao presente pós-moderno quando, ao falar sobre o NAFTA (the North American Free Trade Agreement), por exemplo, conecta o indivíduo a particularidades históricas nacionais mais amplas deixando de marcar o "lugar" como seu "espaço" coincidente.

$\mathrm{Na}$ verdade, esses dois termos permanecem distanciados à espera de serem preenchidos por discursos poéticos e literários, tais como os encontrados nos escritos do autor, pois quando elimina um discurso racional para lançar mão de um discurso sígnico, ele faz os seus espetáculos performáticos apresentarem uma leitura mais emocional. O espectador pode até, muitas vezes, não entender completamente o que está se passando naquele momento, mas “sente” o que está se desenrolando.

Em suas montagens que não deixam de ser alternativas dramáticas experienciadas a todo momento, ele abre espaços para justapor diferentes manifestações, tais como usar galinhas no palco e sons ao megafone. Ao lançar mão desse novo tipo de vivência dramática, Gómez-Peña decompõe e retrabalha o espetáculo em evoluções locomovendo o olhar do espectador em diversas direções e parece caminhar na contramão de um discurso racional. Ele faz surgir para o público uma nova "criatura", outras contextualizações e libera de seu corpo 
uma sexualidade que não deixa de ser um produto da cultura ocidental, mais as forças de seu projeto artístico. O autor decodifica "realidades", acrescenta diferentes caminhos para sua arte ao afirmar que

\begin{abstract}
Em termos de estratégias artísticas, começamos a fundir nossas várias tradições culturais, utilizando a performance como um fio condutor sintático. Misturamos rituais indígenas de várias partes do mundo (ou melhor, nossas interpretações pessoais) com filme e vídeo. Combinamos crônica social com poesia multilingual, arte e literatura, imagem sexual e política; e atuamos indiscriminadamente em espaços artísticos, teatros e nas ruas. Com frequência usamos animais vivos no palco, movimento em slowmotion, nudez, e pintura corporal; e experimentamos aquilo que acreditamos ser estado alterado de consciência induzido por jejum, comilança, álcool ou falta de sono. $\left(1996\right.$, p. 85) ${ }^{1}$
\end{abstract}

Gómez-Peña estreita, por isso, determinadas identidades, fragmenta outras em uma multiplicidade de estilos que destaca o efêmero, o flutuante e a diferença. Gómez-Peña traz mais realidade, mais "vida" para suas representações, pois, viver o teatro é criar uma nova linguagem, abarcar outras realidades e expressar infinitas novidades. Segundo o autor, “Gostemos ou não, uma nova era começou, e uma nova topografia econômica e cultural foram a nós designadas. Agora precisamos encontrar nosso novo lugar e nosso papel dentro dessa bizarra Federação das Repúblicas dos Estados Unidos" ["Whether we like it or not, a new era has begun, and a new economic and cultural topography has been designed for us. We must now find our new place and role within this bizarre Federation of U.S. Republics".] (1996, p. 8-9).

Para o autor, o renascimento e a reconstrução de uma nova identidade cultural passam a ter, dessa forma, um cunho marcado pelo vigor autoafirmativo uma vez que, nesse momento, as novas identidades chicanas formam-se com um forte sentido nacional quando surgem no caminho trilhado pelo mito de origem, o mito de Aztlán, o "lugar sem lugar", reproduzindo a produção discursiva de uma cultura visivelmente fragmentada.

Assim, Gómez-Peña recria imagens e objetos como uma forma de demonstrar que não se conforma com a realidade e que tampouco tem-na como algo definitivo. Ele visa, por isso mesmo, mostrar realidades que não pertencem ao cotidiano. Ao assumir essa posição, ele 
descreve os tipos que formam uma nova estética, uma vez que para compreendermos a trilha de sua arte performática, devemos estar abertos para manifestações alternativas que não encontravam local em outros circuitos.

A importância dessa prática leva-nos a supor os procedimentos utilizados para que a enunciação deixe marcas não apenas sobre o sujeito que cria, mas, a respeito do coletivo, do povo com seus heróis. E esses não são quaisquer heróis, sem história, sem nacionalidade, mas, aqueles identificados pelas impressionantes mudanças presentes em suas trajetórias. Tratamse daqueles heróis legitimados para circunscrever a cultura de um povo. Diante da ameaça para desestabilizar a sociedade, o herói, quase invisível, insere-se em uma forma "neonarrativa", criando um espaço de fala. Por meio dela, as personagens atravessam línguas e linguagens comunicando histórias e contradições. O herói chega mesmo a recusar o mundo codificado para fazer surgir a releitura desse mundo com suas infinitas possibilidades desmembráveis. No seguinte poema de Gómez-Peña podemos observar esse acontecimento:

\section{XXVIII: MEMÓRIA CRUCIAL}

"consiga uma passagem de volta para o México

\& se você não puder

pegue ao menos um pôster da democracia

mas sonhe, sonhe com um lugar melhor

não deixe nunca de sonhar ... em espanhol"

dizia meu tio Carlos, líder do sindicato automobilístico

enquanto morria em Detroit

sozinho entre os fanáticos e recordes quebrados

"mulher, diga aos vizinhos

que nunca fomos esse demônio ... ou essa sujeira"

- ele dizia à minha tia Roberta enquanto estava morrendo em -

Detroit -

"mostre-lhes os poemas de meu sobrinho

o Charromântico

que uiva no palco"

(eu uivo)

e ela o fez

mas meus poemas não caíram bem

no estômago daqueles fanáticos.

ponto.

como milhares de outros

Carlos morreu daí a três meses longe do México

LUZES SOMBRIAS / UM BOLERO TRISTE 


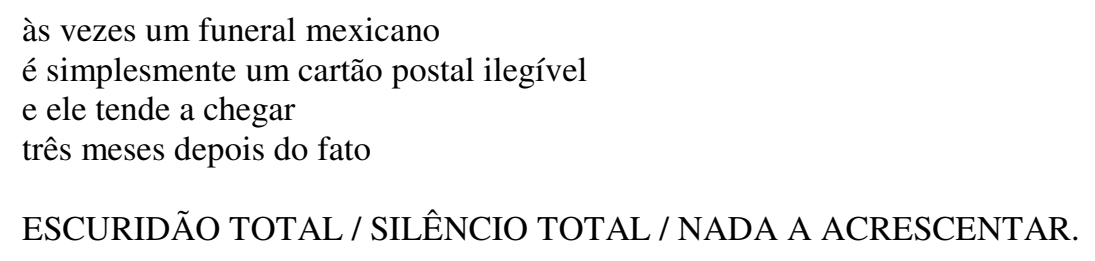

$(1996, \text { p.226 a } 228)^{2}$

Diante dessas configurações, aquele que fala no texto parece manifestar-se com um jeito político e acusador quando cria um novo processo para atingir os receptores a partir de seu enfoque. As séries textuais podem ser entendidas como referencializações modificando a imagem difusa de um testemunho, ou, na impossibilidade de sintetizar tantas formas sob um único rótulo, seguir na mais árdua tarefa de apresentar inovações performáticas e culturais, resultando em polêmicas dramatizações encenadas nas ruas, nas praias e em tantos outros espaços (des)contextualizados. É significativo lembrar que, certa vez, ao dramatizar uma cena em uma praia, Gómez-Peña e Roberto Sifuentes fizeram-se crucificar por três horas. Eles protestavam contra a política xenofóbica do governador da Califórnia, Pete Wilson. A atividade rendeu um ombro deslocado em Gómez-Peña e o desmaio do amigo Roberto, “enquanto algumas pessoas na multidão repreendiam aqueles que tentavam nos ajudar, dizendo: Deixe-os morrer." ["while some people in the crowd rebuked those who were trying to help us, saying, “Let them die!'”] (1996, p. 102).

Pela forma descrita acima, Gómez-Peña faz de suas dramatizações a comunicação eficaz para atingir e recompor o sentimento racial de união, além de apresentar a maneira política de transcender as lutas já existentes nos "mundos" da representação teatral. Acrescentando ao seu trabalho alguns meios eletrônicos como projeções em tela, diferentes sons acústicos no megafone, radiofonia etc, o autor consegue mostrar a notável performance dramática entre as culturas popular e tradicional, ao mesmo tempo que evidencia como essas medidas são teatralizações imaginadas pelo social. Poderíamos dizer que em suas 
representações estéticas existe uma representatividade do real e em sua relação com o mítico, uma vivência desse real.

Dessa maneira, as "verdades" absolutas antes aceitas como resultado lógico, hoje são vistas transformadas de maneira total por meio da sua arte. Gómez-Peña propõe-nos inferir como as estruturas narrativas presentes na "ordem natural" de uma grande narrativa cederam lugar a uma estrutura transgressora do cânone e segue outras linguagens que abarcam uma “personalidade” artística.

Suas palavras fazem do encontro no palco, as performances "dissonantes" que funcionam como recursos básicos para a criação simbólica perturbando o espectador. Assim, o trabalho de Gómez-Peña caracteriza-se mais por apresentar interpretações deformantes, explosões e contrapontos que chegam bem mais próximos das imagens magnéticas dos sonhos, do que ao equilíbrio de um meio dinâmico exprimindo totalidades conceituais. Em consequência, qualquer teoria será insuficiente para analisar por completo a sobreposição de sentidos e imagens (em movimento) que ele intenta dramatizar. Somente ao deslocar significados podemos começar a reconstrução de sua arte para reuni-la em movimentos físicos que suscitem um sentido concreto e especial.

Dessa maneira, emerge de sua escritura uma complexidade de contradições deixadas nos espaços enunciativos de sua arte performática. A "realidade" no aqui-e-agora frente ao espectador revela o choque de olhares entre o eu e o Outro. A respiração e o suor mais o desenvolvimento de uma anatomia singular durante o espetáculo têm participação ativa a fim de que uma criação de identidade seja possível.

Com isso, Gómez-Peña afirma uma ideia de originalidade e, com essa experiência, os degraus são galgados um a um sem que haja imitações, sempre com muita personalidade, sem dispensar o corpo. A imagem passa a ser, portanto, uma ilusão da presença do ator, uma ambivalência acusando uma falta. O que seria uma simplificação acaba por transformar-se em 
um processo de representação enunciativo sempre em evolução. Podemos reconhecer o que acabamos de afirmar por meio das seguintes palavras do autor:

\begin{abstract}
A cada dia, em frente aos visitantes, James e eu transformávamo-nos em diferentes personagens performáticos. Roberto capturava os detalhes dessas transformações em uma vídeo câmera, e essas imagens eram simultaneamente mostradas no monitor da galeria ao mesmo tempo que eram transmitidas ao vivo via Internet. [...] Num certo sentido, éramos etno-ciborgues criados pela imaginação dos usuários da Net. (1996, p. 106) ${ }^{3}$
\end{abstract}

Nesse sentido, não ficamos surpresos quando encontramos em seus textos situações sendo expostas em prosa e verso, inglês, espanhol e francês, em forma de drama e por fotos de dramatizações, tudo misturado, em um ritmo bastante frenético. Talvez seja esta uma busca do artista chicano para sua autolegitimação, pois ele vê-se circunscrito fora do chamado "centro" quando tenta manter um diálogo transnacional com outras artes, tais como as plásticas, as cênicas etc, das Américas contemporâneas. Ele consegue transformar antigas cartografias em expressões de estados de espírito que fisgam o espectador com iscas de surpresa. Gómez-Peña leva esse mesmo espectador a aceitar o próprio logro. Ao apresentar uma determinada cena, por exemplo, ele conversa com o público e fala que quem não desejar participar da brincadeira deve deixar o teatro imediatamente. $\mathrm{O}$ autor acrescenta que precisa de algumas informações básicas, como por exemplo, o número de latinos na plateia (1996, p. 156). Em uma declaração sobre uma de suas performances, ele afirma o seguinte:

\footnotetext{
À medida que ela viajou de lugar a lugar, tornou-se mais estilizada, encenada e excêntrica. Acima de 40 por cento de nossa audiência, tristemente, não importando onde estávamos, acreditou que aquilo que fora exibido era real (pelo menos durante sua primeira visita), e não se sentiu compelida a fazer qualquer coisa sobre isso. $(1996, \text { p. } 98)^{4}$
}

Em consequência, poderíamos perguntar de quais técnicas Gómez-Peña precisa se servir a fim de desvendar o espaço que ele compartilha conosco. Em meio à expressividade contida na estranha voz por debaixo da superfície textual, o autor vê um outro lugar situado 
para além do texto, ou nos faz sentir as dificuldades de transição enfrentadas pelos chicanos quando buscam uma crença em autonomias individuais?

Podemos entender, com essas questões, o poderio do significado das palavras para percebermos as complexas conexões existentes entre o antigo - a tradição cultural - e o novo - as novas formas de expressão -, acusando um silêncio que talvez seja aquele olhar lançado aos locais onde a distinção entre o que é a Raza e o que é estrangeiro entra em colapso.

O contato com o público leva o sujeito a nos oferecer a excelente oportunidade de revelar o excepcional, o aparecimento de novos espaços. Se assim não fosse, qual seria a maneira de se fazer ouvir como a voz de uma coletividade racial?

Desconstruída a noção de homogeneidade tão defendida pela cultura hegemônica do cânone, a inclusão de produções literárias, como as dos Chicanos/as, tem sido efetuada principalmente por meio do fortalecimento da presença da língua espanhola nos Estados Unidos e de suas variantes, tais como o Spanglish, o Tex-Mex e o Caló. Por meio dessas contestações, verifica-se a necessidade de se inscrever neste jogo de poder, as referências às "diferenças" e a articulação dos variados sujeitos dessa diferenciação, pois, não está provado de forma alguma, que uma única linguagem seja a melhor. Pelo contrário, aquela concepção deve ceder lugar a uma linguagem viva, presente e impactante, atingindo o espectador/leior de imediato.

Por estar imerso em duas culturas ao mesmo tempo, a mexicana e a americana, Gómez-Peña olha para os dois lados e não sabe a qual pertence. Filho das transformações pósrevolucionárias entre México e Estados Unidos, ele mescla a chamada alta cultura e a arte popular, manifesta o simbólico da cultura, assim como revela uma experimentação vanguardista e uma consciência sócio-cultural. O autor mostra que, a priori, o povo chicano tem apenas um sonho: não querer voltar para o sul, o México, depois de ter experimentado o gosto de viver no norte, os Estados Unidos, mesmo passando por dificuldades de toda sorte. 
Os chicanos acreditam que se o sonho de enriquecer concretizar-se, todo o empreendimento de migrar não terá sido apenas uma ilusão. Será a realização de uma vida melhor, de fartura, fora daquela vida estruturada por humilhações sofridas até ali. Nesse passo dado em direção ao Norte situa-se o ritual de marcharem um depois do outro, a obediência a um tipo de chamamento contínuo que responderia aos que já foram e não retornaram mais. Gómez-Peña aponta que:

Toda comunidade deve encarar este fato: a Dominação é contextual. Todos nós, em tempos e contextos diferentes, desfrutamos de alguns privilégios sobre outras pessoas e sempre fazemos o jogo de vítima e vitimizador, explorado e explorador, colonizado e colonizador. Agora precisamos ter a coragem de mudar nossa pasmaceira íntima e começar a discutir os assuntos delicados que a maioria de nós evitou no passado. $(1996, \text { p. } 13-14)^{5}$

O sentido que emerge dessas fronteiras caracteriza-se, assim, por exibir a transgressão realizada pelo autor para transpor os limites do gênero prosa e verso, de transformar as linguagens teatral e literária, utilizar-se das línguas inglesa, espanhola e francesa, marcando não apenas uma diferenciação, mas garantindo, por outro lado, a autoridade de enunciar, contida na voz do Outro. Ele celebra essas fronteiras como o processo de transculturação, o espaço móvel de justaposições conferindo incessantes travessias figuradas e literais. Um estado anterior à sua linguagem escolhe uma outra: a linguagem da música, dos gestos, palavras e movimentos. Com isso, ele possibilita que as palavras sejam substituídas pelo gesto e inventa uma linguagem de temas mais abstratos cujos significados estão dentro e fora dela.

Gómez-Peña compõe com esse fervilhar caótico, um verdadeiro quebra-cabeças vivo e em movimento. Não é à toa que suas realizações são corporificadas em plena matéria na própria realidade.

O escritor reforça, com suas produções, uma das muitas complexidades com a qual os chicanos estão envolvidos: la frontera. Resultado de uma produção intelectual e artística, $a$ fronteira tem sido problematizada em obras de vários autores hispânicos. 
Talvez seja por estes motivos que, em meio a tantas mudanças, o problema de quem fala em seu texto deixa transparecer o próprio discurso legitimando-se de acordo com as possibilidades de renovação do literário. Embasado em pressuposições ideológicas, discursivas, emancipatórias e emocionais, quem fala revela que todas essas possibilidades prosseguem fora e além dos limites de fronteiras impondo uma espécie particular de utopia estética testemunhando outras possibilidades.

Seguindo essa trilha, podemos acompanhar o caminho percorrido por Gómez-Peña e perceber que sua performance abarca experiências de vanguarda formando uma equipe piloto de animadores culturais em sua própria obra. Essa experimentação apresenta a performance como uma arte de "fronteira". Em si mesma, ela é uma arte extensamente preparada e pouco improvisada e Gómez-Peña torna-a algo especial para romper convenções, formas e, também, estéticas, para permitir ao mesmo tempo, a quebra e a aglutinação de confrontos com o teatro por meio de inúmeros movimentos. Para isso, ele faz uso de questões complexas como as da representação para que o seu processo de criação seja possível à arte em geral. $\mathrm{O}$ autor preenche o vazio deixado pela vanguarda com tendências de experimentações para adentrar a arte de fazer teatro, e confessa:

\begin{abstract}
A FRONTEIRA DO NOVO MUNDO SEMPRE FOI DESCRITA POR COLEGAS e jornalistas como "arte chicana ciber-punk" e em um determinado momento (embora muitos chicanos importantes ainda tenham dificuldade para considerarem-me um chicano), eu resolvi abraçar a definição. Nessa performance épica alicerçada na linguagem e altamente tecnificada, eu decidi levar minhas fronteiras estéticas (acomodando e opondo linguagens, estilos musicais, sons, e imagens) ao extremo. Meus colaboradores e eu costumávamos usar quatro tipos de som ao vivo e pré-gravados, assim como a tecnologia do estado da arte para mixar e filtrar nossas vozes. Falávamos em Espanhol, Francês, Inglês, Spanglish, Franglé, e muitas "linguagens-robô" construídas. As "traduções simultâneas" eram propositalmente incorretas. A idéia era forçar a platéia a experimentar a vertigem cultural de morar numa sociedade muntilingual/multirracial $(1996, \text { p. } 21)^{6}$.
\end{abstract}

Devemos observar, então, como o teatro faz-nos perceber que, para sua realização é necessário o domínio da montagem, considerada, por isso mesmo, uma espécie de linguagem no espaço e sempre em movimento. 
Por essa perspectiva, o conjunto do material utilizado por Gómez-Peña faz os espectadores visualizarem sua expressão anárquica, pois o autor visa escapar dos limites disciplinantes a que a arte teatral hegemônica esteve submetida. Para tanto, dispõe de uma elaboração performática a fim de provocar o espectador. E, nesse momento, instala-se a busca de imagens perseguidas por meio da sensibilidade.

Somente ao apossarmo-nos de extremos conseguiremos refazer os elos entre o que é e não é realidade para discutirmos a arte de Gómez-Peña. Tamanha provocação acontece entre a virtualidade do possível e aquilo que se encontra na matéria da natureza.

De fato, o autor libera o inconsciente reprimido e assume o valor do que ficara virtual; impõe-nos, a nós espectadores, uma verdadeira atitude heroica de interpretação quando torna a poética teatral possível, apenas no sonho do teatro. Gómez-Peña desperta em nós, com tudo isso, o duplo do silêncio guardado em nosso subterrâneo e enfoca outras espécies de expressão intermediando ausências e a necessidade de substanciá-las. É para esse tipo precioso de teatro que ele nos convida marcando nosso espírito com um verdadeiro delírio exaltador de energias poéticas. A questão faz cair a máscara do engodo para revelar sua força oculta, seu poder obscuro quando busca outros momentos que certamente funcionam como existências próprias.

Portanto, no ilimitado da enunciação, a própria voz da performance defende-se da inesperada referencialização do "real” extraliterário e mostra que, segundo Moreiras, "a verdade de um texto é sua tropologia ou sua ficcionalidade" (2001, p. 251), e revela a existência de uma contratransferência indicando que a integralidade do real deixou de ser objetiva para se apresentar como categorias ficcionalizadas prontas a provocarem a possibilidade de acesso a outros espaços. 


\section{NOTAS}

1- "In terms of strategies, we began to fuse our various cultural traditions, utilizing performance as a syntatic thread. We mixed indigenous rituals from various parts of the world (or rather, our personal interpretations of them) with film and video. We combined social chronicle and multilingual poetry, art and literature, sexual and political imagery; and we performed indiscriminately in art spaces, theaters, and in the streets. We often used live animals onstage, slow-motion movement, nudity, and body paint; and experimented with what we believed were altered states of consciousness, induced either by fasting, overeating, alcohol, or lack of sleep". (GÓMEZ-PEÑA, 1996, p. 85)

2- "get a ticket back to Mexico, / \& if you can't / get a poster of democracy at least / but dream, dream of a better place / no dejes nunca de soñar ... en español" / said my uncle Carlos, automobile union leader / while dying in Detroit / alone among bigots and broken records / "mujer, tell the neighbors / we were never that evil ... or dirty" / - he told my aunt Roberta while he was dying in / Detroit - / "show them the poems of my nephew / el Chorromántico / que aulla en el escenario" / ( I howl) / \& she did / but my poems didn't sit very well / in the stomach of those bigots. / punto. / like a million others / Carlos died three months away from Mexico / DIM LIGHT/A SAD BOLERO / sometimes a Mexican funeral / is just a illegible postcard / \& it tends to arrive / three months after the fact / TOTAL DARKNESS/TOTAL SILENCE. NOTHING TO ADD” (GÓMEZ-PEÑA, 1996, p. 226 a 228)

3- "Each day, in front of the visitors, James and I transformd ourselves into performance personae. Roberto captured the details of these transformations on a video camera, and these images were shown simultaneously on the gallery's video monitors and were also transmitted live onto the Internet [...] In a sense, we were ethno-cyborgs, created by the imaginations of the Net users". (GÓMEZ-PEÑA, 1996, p. 106)

4- "As it traveled from site to site, it became more stylized, staged, and whimsical. Sadly, over 40 percent of our audience, no matter where we were, believed that the exhibit was real (at least during their first visit), and did not feel compelled to do anything about it”. (GÓMEZ-PEÑA, 1996, p. 98)

5- "Every community must face this fact: Dominance is contextual. We all, at different times and in different contexts, enjoy some privileges over other people and perform the ever-changing roles of victim and victimizer, exploited and exploiter, colonizer and colonized. We must now have the courage to turn our gaze inward and begin to raise the touchy issues that most of us avoided in the past". (GÓMEZ-PEÑA, 1996, p.13-14)

6- "THE NEW WORLD BORDER WAS OFTEN DESCRIBED BY COLLEAGUES and journalists as "chicano cyber-punk art" and at one point (though many essentialist Chicanos still have a hard time considering me a Chicano) I chose to embrace the definition. In this language-based and highly technified epic performance, I decided to push my border aesthetics (layering and clashing of languages, musical styles, sounds, and images) to an extreme. My collaborators and I used four sources of prerecorded and live sound, as well as state-of-the-art technology to mix and filter our voices. We spoke in Spanish, French, Emglish, Spanglish, Franglé, and several made up "robo-languages". The "simultaneous translations" were purpousely incorrect. The idea was to force the audience to experience the cultural vertigo of living in a multilingual/multiracial society" (GÓMEZ-PEÑA, 1996, p. 21) 


\subsection{O pós-moderno emergente na obra de Gómez-Peña}

Logo na introdução de The New World Border, o autor se define como "UM ARTISTA/ESCRITOR MEXICANO NÔMADE EM PROCESSO de chicanização” e que, por isso mesmo, apresenta múltiplas identidades, além de pertencer a determinadas fronteiras sem se fixar em nenhuma delas ["I AM A NOMADIC MEXICAN ARTIST / WRITER IN THE PROCESS OF Chicanization".] (p. I). Ao contrário, “vive” por "entre” todas, de forma a perpetuar o jogo das aparências, integrando de modo essencial, a construção de uma memória coletiva, de um momento para ativar a consciência cultural.

Ele comenta que "essa obra é uma ode desnarrativizada" ["this book is a disnarrative ode"] (p. I) e que assim, pode oferecer aos seus leitores os seus pensamentos, suas atuações, seus símbolos quebrados, sua linguagem híbrida, mais seus costumes e sua eclética coleção de máscaras (p. III), para historicizar a cultura chicana dentro de um campo tão infinito quanto o das performances realizadas por ele.

Transpondo os limites fronteiriços surgidos por meio de experimentações literário/performáticas, o autor indica o momento em que sua linguagem manifesta a aguda razão de se procurar uma resposta para o confuso mundo oferecido por ele, assim como o modo invertido com o qual tem apresentado sua maneira de narrar. Desses eventos, ele nos garante um certo estranhamento quando se refere à necessidade de transcender a divisão de sua arte e de sua cultura e, então declara:

Eu espero de todo meu coração que este livro contribua para a classificação das grandes crises de nosso tempo, e para o mapeamento de uma cartografia mais esclarecedora para o próximo século. E eu espero que, a despeito de sua natureza experimental, ele não se torne apenas mais um texto obscuro a ser discutido pelos teóricos da arte e pelos críticos culturais. Ele deve falar a artistas politizados, a estudantes, jornalistas, ativistas, professores, piratas técnicos, roqueiros alternativos, pensadores utópicos, organizadores culturais radicais, anarquistas, e cruzadores de fronteiras de toda espécie - a qualquer um que estivesse pensando alto e lutando para reaver as liberdades que nossas classes políticas e corporativas nos roubaram tão eficientemente durante os últimos quinze anos. $\left(1996\right.$, p. II) ${ }^{1}$ 
A capacidade fundamental de se colocar e as possibilidades de sua arte pertencem, segundo essa sua característica, a uma confrontação direta entre passado e presente, entre político e histórico, entre poética e paródia, entre paradoxo e definição. Conforme verificamos por toda obra, este modelo segue um caminho de reinterpretações críticas reavaliando fronteiras entre a arte literária e o mundo da performance.

Sendo assim, seu poema "FREEFALLING TOWARD A BORDERLESS FUTURE” (p. 1 a 3), revive a referência semântica da contraditória independência a que os chicanos sempre se viram enredados para, então, alcançarem suas pretensões. Como uma reativação desses contextos, a arte de Gómez-Peña relata a evolução da integridade chicana desde o passado histórico e questiona as atuações enredadas no futuro, esperando por uma resposta. Ele apresenta uma arte ativista, progressista. Sua arte é do tipo que prediz mudanças. Segundo ele,

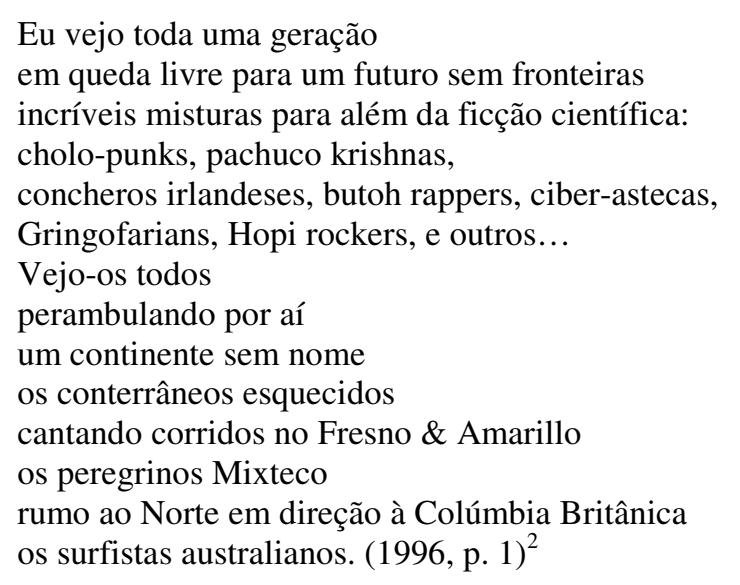

Essa expressão estética tem, como podemos observar, um projeto ligado a uma atitude rebelde das produções artísticas pós-modernas nas quais Gómez-Peña se insere.

Com sua escrita, analisamos como um povo híbrido leva consigo, segundo ele, um pedacinho do Alasca, do Canadá, dos Estados Unidos, do México, da América Central, do 
Caribe, América do Sul, Patagônia, Antártica e outras fronteiras, como uma maneira de fazêlos criar uma "combinação" com todas essas nações (p. 2-3).

A "arquitetura" referencial produzida com esse tipo de trabalho mostra como o discurso do autor reivindica empreendimentos sócio-econômicos e determinadas políticas culturais para que o povo chicano exista como aquele que não é mais uma minoria esquecida, mas como aquele que tem seu grito de luta, sua voz. De acordo com Yúdice,

a política cultural tornou-se fator visível para repensar os acordos coletivos. Exatamente esse termo reúne o que na modernidade pertencia à emancipação, por um lado, e à regulação, por outro [...] essa conjunção é talvez a expressão mais clara da conveniência da cultura. (2004, p. 45)

A partir daí, ressalta-se a enunciação de Gómez-Peña como forma de conclamar o povo para cuidar da cultura assim como da tradição histórica. Para ele, é melhor instigar o humor de cada leitor com lembranças e revelações do que provocar a solidariedade por meio de temas que revelem, apenas, a marginalidade vivida pelos chicanos.

No ensaio intitulado "THE FREE TRADE ART AGREEMENT / EL TRATADO DE LIBRE CULTURA” (p. 5 a 20), o autor anuncia uma América diferente, com pessoas, cidades, fronteiras, e nações diferentes. Para Gómez-Peña, a multiculturalidade nasce aqui para mudar o sentido do procedimento geral a que estava submetida a sua cultura e a dos Estados Unidos (à qual pertence na atualidade). "EU SOU UM ARTISTA MIGRANTE DE PERFORMANCE. ESCREVO EM AVIÕES, TRENS e cafés. Viajo de cidade em cidade, de costa a costa, de país a país, contrabandeando minha obra e a obra e as idéias de meus colegas”, exclama ele. [“I AM A MIGRANT PERFORMANCE ARTIST. I WRITE IN AIRPLANES, TRAINS, and cafés. I travel from city to city, coast to coast, country to country, smuggling my work and the work and ideas of my collegues".] (p. 5). 
A questão a ser estudada são as novas cartografias surgidas aqui e acolá, e os chicanos que, isolados até então, passaram a fazer parte de um "quarto mundo" sempre em mudança.

Apesar de toda essa divisão, as redes estéticas que levam Gómez-Peña a produzir seu lugar, dependem de um espaço econômico-material e de suas interfaces com questões cívicas para que os aspectos de identidades façam sentido nesse todo de se pertencer a uma cultura multiplicada e compartilhada por todos. Segundo Yúdice,

Seria realmente cínico qualificar políticas de identidade como uma aberração quando a conveniência da cultura é uma característica óbvia da vida contemporânea. Ao invés de nos atrelarmos à censura, pode ser mais efetivo para os propósitos do pensamento estratégico estabelecer uma genealogia da transformação da cultura em recurso. O que ela nos assinala a respeito do nosso período histórico? (2004, p. 47)

No âmago dessa (re)elaboração, está a diferença que distingue a atenção dispensada por Gómez-Peña em canalizar suas performances, assim como as convenções paratextuais de uma historiografia estrangeira inserida em seu discurso. Para o autor, as identidades já não são mais estáticas e tampouco as nacionalidades são fixas, pois o "NAFTA (North American Free Trade Agreement) assinado pelo Canadá, os Estados Unidos, e México, criou a maior comunidade artificial econômica do planeta" ["The North American Free Trade Agreement (NAFTA) signed by Canada, The United States, and México, has created the largest artificial economic community on the planet".] (p. 7).

O caminho a ser produzido ocupa, doravante, os momentos livres do pensamento do autor e dele são retirados alusões ao medo de os chicanos serem massacrados pelas grandes potências, em particular a dos Estados Unidos. A preocupação que desponta é quanto à Estátua da Liberdade ter ou não a audácia ou a ousadia de "poder" devorar a Virgem de Guadalupe, esta, importante símbolo de bravura e de santidade para os chicanos.

Amarrado às margens históricas de apresentar acontecimentos e novidades da vida cotidiana, Gómez-Peña comenta que, quer o povo chicano goste ou não, uma nova era começou e que o "centro", ou seja, os ideais europeus começaram a ser reconquistados pelas 
“margens", pelos excluídos da prática política até então. Uma reflexão sobre o significado da "deficiência" étnica chicana fica a cargo do seu pedido de debate instalado com a nova ética da representação. Hoje, o espaço vazio deixado pelo instante das representações começou a ser preenchido pela multiplicidade de identidades, de vozes e do discurso significativo que, pelo cerne de pensamentos transformadores, tem lutado para conquistar o espaço dos chicanos na sociedade.

Há muitos anos a literatura chicana tem se debruçado sobre o tema da "marginalidade". "Eu oponho a sinistra cartografia da Nova Ordem Mundial ao mapa conceitual da Nova Fronteira Mundial - uma grande zona de fronteira trans- e intercontinental, um lugar onde nenhum centro permanece", sugere Gómez-Peña, para nos fazer pensar no vale-tudo dos seus "ditos" e escritos pós-modernos. ["I oppose the sinister cartografy of the New World Order with the conceptual map of the New World Border - a great trans- and intercontinental border zone, a place in which no centers remain”.] (p. 7).

A experiência para Gómez-Peña, agora, é deixar de submeter-se a uma ordem contínua dos desmandos estrangeiros e descrever como as estruturas de sua própria sociedade têm se solidificado para enfrentar o desconhecido e o poder do Outro.

Assim, Gómez-Peña tem dado provas do quanto tem se empenhado em suas trajetórias pessoais para definir os rumos dos irmãos chicanos, rumos esses sempre imprevistos, incitando-os para que repensem as situações locais e ambientais constituídas num objeto e numa sensibilidade participativa de toda e qualquer luta.

Nesse ponto, a realização de seu discurso marca o encontro das águas em comentar que latinos e latino-americanos são diferentes uns dos outros, que "são separados por fronteiras invisíveis e idiossincráticas" e que "ninguém está imune ao vírus do colonialismo internalizado" ["we are separated by invisible, idiosyncratic borders" [...] "No one is immune to the virus of internalized colonialism".] (p. 14). 
Assim, Gómez-Peña retoma a difícil situação de marginalizados a que as comunidades estavam sendo submetidas e nos faz perceber a divisão que passou a existir entre gêneros, raças, classes, além da divisão da própria identidade: "Eu quero propor uma terceira alternativa: o híbrido", sugere ele, "o híbrido cultural, político, estético, e sexual. Minha versão de híbrido é cruzar raças, é poli-linguística, e multicontextual” [“I wish to propose a third alternative: the hybrid - a cultural, political, aesthetic, and sexual hybrid. My version of the hybrid is crossracial, polylinguistic, and multicontextual”.] (p. 11-12).

A América, também, encontra-se dividida, segundo ele e, para acabar com essa beligerância, comenta que seria preciso um cessar fogo trazendo consigo um tratado de paz temporário. Só assim a circulação de elementos tão díspares seria capaz de estocar realidades tão desarticuladas entre si. Esse exemplo revisa seu jeito de pensar, sua valorização estética e filosófica. Para Gómez-Peña, a aproximação com o leitor e com seus expectadores facilitaria a criação de relações sociais originárias de uma aspiração das massas atuais. Tanto para ele quanto para as políticas culturais inseridas nessa totalidade eles-eu, o importante seria formar atividades que revivessem o reconhecimento do passado como tal, mas que, também, formassem a emergente designação dos novos significados e valores de sua sociedade no presente, pois, para Gómez-Peña,

\footnotetext{
O mundo da arte é uma família disfuncional - um micro-universo refletindo a sociedade maior. Artistas e acadêmicos raramente se falam. "Artistas de comunidade" e artistas politizados que trabalham em instituições importantes ainda se vêem como inimigos, e não como aliados trabalhando em diferentes frentes. Artistas que trabalham diretamente com comunidades problemáticas tais como os sem-teto, prisioneiros, trabalhadores imigrantes, ou com partes pobres das cidades, são vistos como oportunistas e suas intenções estão constantemente sendo questionadas. Artistas de cor "bem sucedidos" são vistos como os que têm "co-optado", ou como "vendidos". Os que se aventuram na teoria são acusados de serem elitistas, não "orgânicos" em relação à sua comunidade. (1996, p. 14)
}

Por meio desse extenso percurso, Gómez-Peña retoma seu ponto de partida comentando que as comunidades étnicas têm mudado drasticamente e que "a arte do mundo é uma comunidade particularmente estranha" ["The art world is a particularly strange 
community"] (p. 17). Dessa subjetividade nasce, também, sua preocupação com os adolescentes: "Os mais velhos são ignorados e as crianças são vistas como estorvo", comenta ele. ["Elders are ignored and children are seen as a nuisance"] (p. 17). Talvez aqui se encontre a fonte de algumas preocupações de Gómez-Peña. Qual desígnio terá sua raça nesse mundo interconectado? Como delinear figuras a serem seguidas como modelo se a cada manhã o mundo encontra-se infinitamente diferente da noite anterior?

De uma maneira ainda mais concreta, neste capítulo cruzam-se momentos que abordam a problematização a respeito de qual "lugar" ocupar nessas investidas. O fantasma marcando a percepção de Gómez-Peña, seus devaneios e suas paixões em como solidificar-se como artista que ocupa diferentes posições entre esta e aquela fronteira, inclui um dinâmico crescimento de sua arte de experimentações. "O grande projeto de reforma e reconciliação devem ser, acima de tudo, um colaborador, e todas as comunidades implicadas devem tomar parte nele", conclama Gómez-Peña. ["The great project of reform and reconciliation must be, above all, a collaborative one, and all concerned communities must take part in it".] (p. 18).

Em seu texto performático "THE NEW WORLD BORDER: Prophecies for the End of the Century" (p. 21 a 48), Gómez-Peña apresenta-nos inúmeras figuras preliminares simbolizando posições assumidas por ele para representar diferentes fronteiras estéticas.

As fronteiras já não trazem mais, aqui, apenas imagens de identificação do públicopovo, de uma situação diferenciada de estilo, ou de heróis homéricos. As fronteiras falam do capital cultural acumulado, dos habitantes do país que lideram seus pontos de vista, e do sistema econômico por meio dos quais a arte performática de Gómez-Peña se organiza e se confirma para focalizar a raça, originária de uma tradição espanhola. Nesse sentido, segundo Yúdice, 
Apesar do profundo ressentimento contra os imigrantes sobretudo na Califórnia, o capitalismo empresarial apoiou os megaeventos artísticos destinados a fomentar as relações públicas na fronteira, que incluíam "chicanos e artistas de cor americanos", que, contrariamente às previsões de Gómez-Peña, não foram "vistos de soslaio". De fato, o capitalismo empresarial se adaptou ao ritmo da "descentralização", de forma semelhante ao ainda melhor do que artistas de performance progressista [...] Em consonância com a retórica do livre-comércio, pode-se dizer que a região San Diego-Tijuana é personificada tanto pela fronteira como pelos 63 milhões de cruzamentos que a desmentem. GómezPeña (1993), frustrado pela fácil apropriação do tropo "alternativo" da fronteira, insiste que é hora de os artistas fronteiriços "buscarem outro paradigma para explicar as novas complexidades dos tempos". (2004, p. 345-346)

Descrito desde o início por colegas e jornalistas como sendo uma "arte chicana ciberpunk" [“chicano cyber-punk art”], o texto "THE NEW WORLD BORDER: Prophecies for the End of the Century", de acordo com o próprio autor, "realmente não tem enredo e sequer ‘personagens' reconhecíveis. As atuações no palco são meras imagens midiáticas e clones da realidade virtual de nossas próprias identidades (ficcionalizadas)" [“there is really no plot, nor recognizable "characters". The performers on stage are mere media images and virtual reality clones of our own (fictionalized) identities".] (p. 21).

E para exaltar ainda mais o inquietante critério adotado para sugerir seu universo performático, Gómez-Peña leva em conta a atual circulação de poder de seu discurso para tornar possível que sua fala chegue tanto às elites quanto ao popular. Ele apela, apropria-se de um material simbólico que, ao mesmo tempo oferece a distribuição dos bens culturais para o leitor-espectador e experiencia a divisão técnica e social do trabalho executado. "Sempre fomos visitados pelos ativistas dos direitos dos animais que desaprovavam nossas 'violentas ações contra as galinhas', e veementemente nos acusavam de 'dessacralizar os animais' em nome da arte", exclama ele. ["We were often visited by animal rights activists who objected to our "violent actions toward the chickens" and vehemently accused us of "desecrating animals" for art's sake".] (p. 22).

A afirmação funciona como um recurso para produzir as diferenças entre os grupos sociais e o discurso hegemônico do outro, patrimônio que serve para desunir as nações, segundo o ponto de vista do autor. Quando ele se ocupa em falar desse território, fica claro 
sua luta como nativo que tenta recuperar sua identidade e resgatar seus bens sócio-culturais para colocá-los sob sua soberania. Nas cenas dramatizadas de suas performances, esses rituais cotidianos tornam-se o cerimonial por meio do qual se apresentam construções de um espetáculo híbrido. De acordo com Yúdice,

\begin{abstract}
Capitalistas e progressistas viram na hibridação uma espécie de tábua de salvação produzida pelos chamados novos imigrantes, que voltaram a traçar o mapa da América, parafraseando o artista Guillermo Gómez-Peña. "As culturas mexicana e caribenha", afirma (idealizando-as, na minha opinião), "podem oferecer ao Norte sua força espiritual sua inteligência política, o senso de humor para enfrentar a crise e sua experiência na promoção das relações pessoais e comunitárias". Por outro lado, os defensores dos grandes centros urbanos metropolitanos consideram que os recursos culturais da diversidade constituem uma das formas mais importantes do renascimento econômico. (2004, p. 339)
\end{abstract}

Considerando essa posição de Yúdice, podemos perceber toda a transmutação (performática) de Gómez-Peña que se distingue nas proposições em renovar os intercâmbios artísticos para poder acompanhar a nova realidade mundial. $\mathrm{O}$ autor se permite criticar de maneira exagerada, dá início às mudanças nas leis que o levam a compactuar com a máquina do sucesso e empreende o jogo de chocar os espectadores com galinhas no palco e suas mortes por degolamento. Ele também usa várias línguas para se expressar ao megafone e traveste-se para propor a exploração das diferentes misturas de raças, identidades híbridas, adoração de novos deuses, em um esforço de nos fazer acreditar que todos somos fronteiriços. “Sim, estamos ligados por redes imaginárias [...] membros de uma sociedade ficcional, não mais definidos pela etnicidade, pela ideologia, nacionalidade, ou pela linguagem, mas pelo tempo" ["Yes, we are linked by imaginary networks [...] members of a fictional society, no longer defined by ethnicity, ideology, nationality, or language, but by time”.] (p. 25).

Gómez-Peña transformou-se naquilo que é de fato, herdeiro de um esforço que o obriga a afirmar sua arte como um repertório de saberes pronto a ensinar na sala de espetáculos ou em qualquer outro lugar. "No rastro dessas atormentadas mudanças do bloco da ex-União Soviética, os ventos da gringostroika atingiram cada cantinho de nosso continente. Ainda podemos chamá-los "nosso"? De qualquer forma, quem somos "nós"?, 
acrescenta ele. ["In the wake of the stormy changes in the ex-Soviet bloc, the winds of gringostroika have reached every corner of our continent. Can we still call it "ours"? Who are “we” anyway?”] (p. 27).

Os poucos autores que se colocam essa forma de investigação têm indagado de Gómez-Peña sobre o importante rito de iniciação a que devem se submeter para perceberem as diferenças sociais determinando o cenário dos contrários. Mais que qualquer outra batalha, as intervenções estrangeiras na cultura chicana têm sido denunciadas em cada uma de suas manifestações artísticas. As teatralizações do cotidiano já não acompanham apenas o distanciado ritual moderno, mas encara, por outro lado, qualquer possibilidade de ele separar e olhar, como espectador, aquilo que está partilhando. E disso ele não nos exclui. Pelo contrário, Gómez-Peña nos chama para participar dessa arquitetônica e cenográfica ligação entre o outro e eu, entre fatos de lá e os daqui, dessa produção toda e do desconhecido. "Nova Ordem Mundial, Nova Desordem, Nova Ordem Mundial, Arte do Livre Comércio, Utopia, Utopia, 93 ...”, ele exclama. [“New World Order, New Disorder, New World Order, Free Trad Art, Utopia, Utopia, 93 ...”] (p. 29).

Dado o caráter da afirmação acima, Gómez-Peña joga com as megarrealizações e com as realizações menores para que o espectador/leitor, pronto para enxergar o digerível, consiga acompanhar a significativa interação entre palco e público. A partir daí, todos nós nos obrigamos a admitir determinados signos da pós-modernidade se quisermos que o discurso do autor seja verossímil. Ele escreve sobre fatos atrozes que vitimaram as populações ao redor do mundo e de como tudo isso modificou sua vida. Para a maioria das pessoas, essas questões podem parecer, até, interrogações disparatadas, mas, para ele, são inquietações presentes que não passam despercebidas.

Gómez-Peña também não ignora a proporção dos que parecem não dar ouvidos à sua voz, os quais, por meio de frases lacônicas, mal lhe respondem quando questionados: "Se 
você, latino-americano mal agradecido, não gosta disso aqui, por que não volta para onde você veio"?, indaga ele. ["if you ungrateful greasers don't like it here, why don't you go back where you came from?'] (p. 31).

Assim, sua própria relação com a arte ativista, marca a mostra de confusão que tem predominado mundo afora quando se quer tratar de temas relativos à estética e à representação da realidade. O trânsito por essas fronteiras tem sido feito por discursos que sempre remapeiam e redefinem a fronteirização dialógica entre culturas e, para Gómez-Peña, não tem sido diferente. Ele mostra como o dominado, especialmente o trabalhador indocumentado, sempre anseia por transitar entre as "margens proibidas" e como isso lhe permite que se habilite para essa capacidade. Segundo ele, "todas as fronteiras do continente americano estarão abertas no início de 1995. Não será pedido nenhum passaporte". ["Beginning in January of 1995, all borders on the American continent will be open. No passport will be required".] (p. 32).

Com isso, seus propósitos artísticos assessoraram qualquer programa que se estabeleça para dirigir questões de representação cultural e sua implicação direta com o desenvolvimento de programas centrados em todo tipo de atividade artística. Ainda de acordo com Yúdice,

\footnotetext{
Gómez-Peña vê-se no ápice de uma nova era e se descreve como uma espécie de Zelig pioneiro que nos trará visões de uma utopia híbrida, supostamente valiosa para o leitor. Mas essa ubiquidade e essa hibridização têm um valor localizado que circula de um modo específico nos circuitos acadêmicos, artísticos e culturais dos Estados Unidos. Em outras palavras, vende-se bem nesse país. Nestor Garcia Canclini entrevistou vários residentes de Tijuana, bem do outro lado da fronteira, um dos locais de operação do "Taller da Arte Fronterizo/Border Arts Workshop". Os "locais" manifestaram sérias reservas quanto à ubiquidade de "quem cruza a fronteira". (2004, p. 342)
}

Gómez-Peña e nós, dessa forma, transgredimos o limite do racional e pela palavra da melodiosa poética, reconhecemos o sentido da "cultura pop híbrida" ["hybrid pop culture"] (p. 37). Essa ideia livre também se evidencia na propaganda midiática das complexas dimensões da região e do mundo. Gómez-Peña determina situações, enfrenta os desafios impostos pela migração mas não deixa de ter uma comunicação transnacional como escrita 
generalizante não apenas uma noção de cultura fronteiriça, mas que especifica, também, como acontece essa heterogeneização espacial. Sendo assim, o autor mantém diálogos com os espectadores e confessa que estranhamente sente a angústia de perceber o colapso do mercado artístico, pois, “a única coisa que sobrou da 'cultura alternativa' é um canal pornô de esquerda chamado Acesso Pubiano à TV. Ele é especialista em pornostálgicas novelas marxistas" ["The only think left from the old "aternative culture" is a leftist porno channel Pubic Acces TV. It specializes in pornostalgic marxist soap operas".] (p. 40).

Dessa maneira, seu frenético entusiasmo perante a "arte do livre-comércio" o faz entrar em conflito com a "benevolência" de ambos os lados da fronteira. Na verdade, esse tipo de disposição não impede que Gómez-Peña chegue ao público por meio de seus propósitos em formar jeitos de pensar que se assemelham a uma invasão de privacidade. $\mathrm{O}$ autor tem interagido com culturas díspares e híbridas resultando, tudo isso, numa integração supranacional que o identifica com os vários aspectos de tema geral da globalização.

Munido de uma diversidade que alia raça, língua e cultura, Gómez-Peña tem migrado para considerações análogas à circulação de um "tratado de arte-livre" ["the free trade art"]. Segundo ele, "a veterana pop star da época Madonna reencarnou como Santa Frida Kahlo. Ela perambula pelas desagradáveis ruas de Mexa York à procura de pessoas que sofram de bolhas de identidades para curá-las” [“Aging pop star Madonna has reincarnated as Saint Frida Kahlo. She roams around the nasty streets of Mexa York in search of people who suffer from identity blisters and heals them".] (p. 41).

Gómez-Peña defende o reconhecimento de uma arte que consiste em abrir a maneira de uma outra realidade para a comprovação da existência de possibilidades consideradas menores até então. Assim, ele comenta sobre as máfias e afirma que "o medo da incerteza gera o sectarismo" ["Fear of uncertainty generates sectarianism".] (p. 44). 
Nesse ponto da realização, a performance triunfa sobre as tentações do contrário e, mais uma vez, acontece a degola de frangos no palco numa visível demonstração metafórica afirmando que os chicanos também têm suas cabeças degoladas pelo imperialismo estadunidense. Na verdade, caminham nesse espaço descortinado, as singularidades do discurso de Gómez-Peña que identifica um profundo esquema político aquecendo a "morte" daquele considerado inferior, no caso, os chicanos.

Finalizando a apresentação, é perguntado à plateia se há alguém ali que queira passar uma noite de sexo com algum artista, numa alusão desenfreada ao chamado "Sexo do Livre Comércio, o máximo da experiência fronteiriça" ["Free Trad Sex, the ultimate border experience".] (p. 46).

Acima de tudo, essas formas de transgressão dimensionam a estrutura idealizada existente entre a obra em si e a obra apresentada. Nas duas maneiras de manifestação prevalecem ambivalências demonstrando um resultado verossímil, pois ambas estão apoiadas em convenções aceitáveis pelo leitor/espectador.

Seguindo seu movimento de aproximação entre vida e arte, a crônica escrita por Gómez-Peña sob o título de “REAL-LIFE BORDER THRILLER” (p. 50 a 56), nos mostra como foi sentir o desespero de ter sido acusado de sequestrar o próprio filho.

Aqui, um pouco da história desse sequestrar o viabiliza imaginarmos como tudo aconteceu na vida real. Nossa consciência parece compreender que as narrações sobre os imigrantes e os indocumentados são uma atividade cuja mensagem não está livre do racismo e da publicidade caso se queira que elas sejam aprovadas pelas regras do outro para serem consideradas pela crítica. Uma noção alternativa e mais inclusiva é contrastar os fatos do diaa-dia dos chicanos com o cotidiano das elites e esperar que a opinião de todos endosse e aprove aquelas cenas considerando a premissa de que nada é esquecido pela minoria. 
Gómez-Peña desencadeia mudanças culturais geralmente bastante importantes à determinação de suas identidades e, assim, conta que, certa vez, quando algumas pessoas o viram, ele, um homem de cor, indígena, em companhia de um menino branco, loiro, acionaram a polícia e teve início uma emocionante perseguição por sequestrar o iflho em que até mesmo um helicóptero foi usado. A confusão somente foi desfeita porque Gómez-Peña comunicou-se em inglês e pôde se explicar aos policiais e, também, por ter contado com a colaboração de amigos que depuseram a seu favor. Além do mais, contribuiu para não ser preso o fato de ele portar uma carteira da imprensa identificando-o como jornalista. "O que teria acontecido se, como milhares de mexicanos em San Diego, eu não falasse inglês, ou não tivesse uma carteira da imprensa comigo?", ele questiona. ["What if, like thousands of Mexican in San Diego, I didn't speak English or didn't have a press card with me?'] (p. 55).

O incidente narrado tem, com certeza, significados transparentes. Tudo é restrito aos “mex-chicanos", até mesmo o fato de se locomoverem livremente pelas ruas. O contexto da política cultural, nacional ou local dos Estados Unidos não permite que um negro, ou um indígena, ou qualquer outro estrangeiro possa ir e vir sem que isso lhe cause algum dissabor ou que seja, no mínimo, olhado de soslaio. O enfoque que é dado a essas diferenças, de modo geral, faz os chicanos serem identificados como os subalternos que se distinguem apenas pelo grande número de pessoas que incomoda o grupo dominante, o do "lado de lá" da fronteira.

Revitalizando sua narrativa, o autor comenta que muitos

Latinos e outras pessoas de cor são regularmente "confundidas" como "estrangeiros ilegais", membros de gangs, traficantes e estupradores, e sempre esses "enganos" são levados à resoluções mais extremas como encarceramento, pancadaria pelos civis ou pela polícia, e deportação. $(1996, \text { p. } 55)^{4}$

A partir dessas observações, Gómez-Peña nos propõe uma espécie de discurso acusador de outras possíveis ocorrências: a polícia nunca pede desculpas, e a experiência que ficou para o filho foi a de que "sair com o papai pode ser uma experiência perigosa" ["to go out with Daddy can be a dangerous experience"] (p. 56), ou que um programa de fim de tarde 
pode transformar-se no pesadelo de ir para a cadeia, ou em morte, todos desafios das novas formas de segregação e violência.

Ampliando seu discurso, o poema escrito em 1994, "I COULD ONLY FIGHT BACK IN MY POETRY”' (p. 58-59), Gómez-Peña comenta que o Texas já foi um território mexicano e que a essa agressão ele pode responder, apenas, com sua poesia, uma alternativa que se não for aceita, pelo menos significa a eliminação de barreiras ligadas pelo abandono. Esta denúncia nos mostra a tentativa de ele nos apontar que o passado histórico do povo chicano nunca foi desinteressante e tampouco não próspero.

Podemos nos perguntar, a essa altura, quais impedimentos ainda obscurecem a poesia de Gómez-Peña, além de todas essas interrogações sobre as representações centradas na riqueza de seus dados, de seus testemunhos. A sociedade, por meio de suas relações de diferença, ainda fala, de modo claro, como funciona o motor da comercialização dos valores artísticos que chegam ao mercado. As demandas de inclusão e de participação aumentam e polarizam uma análise mais detalhada da poesia do autor. Talvez por tudo isso, nós o vemos exclamando: "Veja, eu te falei, cara, eu ganho a maioria de minhas lutas / pelas ruas de minha poesia" ["See, I told you culero, I win most fights in / the streets of my poetry".] (p. 59).

A tentativa de equilibrar a diferença de "ser alguém" para Gómez-Peña, como vemos, é a resposta que ele oferece às esferas públicas incluídas na abrangente sociedade latinoamericana. Fazer parte da "poesia local" é, para ele, alguma coisa que não pode ser negada.

Superposto a esse poema, um outro escrito no mesmo ano intitulado "THE PSYCHO IN THE LOBBY OF THE THEATER" (p. 60-61), narra seu encontro com um louco e sua argumentação, segundo a qual, "a melhor maneira de lidar com psicopatas é por meio da confrontação poética" ["the best way to deal with them is through poetic confrontation"] (p. 
60). Aquela confrontação que não deixa de ser política, uma vez que a autopromoção e a promoção do Outro dependem de um diálogo que observa o quanto a ética política, nesses momentos de encontro, é claramente progressista. Ou dito de outra forma, é preciso que, tanto o meu direito de argumentação quanto o direito do Outro, estejam em uma escalada de lideranças para se concretizarem em discurso de ambos os lados. Segundo Yúdice,

\begin{abstract}
O que conecta sujeito e sociedade são as forças performativas que operam, por um lado, para "arrear" ou fazer convergir as muitas diferenças ou interpelações que constituem e singularizam o sujeito, e, por outro lado, para rearticular um maior ordenamento do social. Tanto os indivíduos quanto as sociedades são campos de força ou "leis" que constelam a multiplicidade [...] a tensão entre essas forças ou "leis" torna possível aos indivíduos-enquanto-constelações mudar e não conformar-se com as circunstâncias. (2204, p. 54)
\end{abstract}

Acredita-se que apenas assim possa haver outros acúmulos de "capital imaterial" prontos a constituírem parte de um imaginário mais participativo. Senão, como posso querer que o meu discurso esteja presente se eu não der oportunidade para um entrelaçamento com o discurso estrangeiro? Parece ser essa a questão a que Gómez-Peña se refere: um encontro entre a "loucura" do outro e a minha, as antagônicas oportunidades que a vida nos oferece, a virtude de tornar visível toda essa integração.

Conhecido por sua arte bombástica, Gómez-Peña continua seu caminho artístico/literário apresentando-nos um ensaio escrito entre 1994 e 1995, sob o título de “THE '90s CULTURE OF XENOPHOBIA: Beyond the Tortilla Curtain”'(p. 63 a 71). Aqui ele comenta que é um ser vivente das fronteiras, um binacional e que a "fronteira" tornou-se sua casa, sua base de operações e seu laboratório para experimentação artística e social (p. 63). Somente quando se mudou para New York sentiu-se um verdadeiro imigrante. Segundo Mignolo, "é o local (isto é, as histórias locais) que exige a reflexão, não o fundamento universal da mente humana traduzida como um conceito local de razão transformado em um dos conceitos cruciais do imaginário do mundo colonial/moderno" (2003, p. 262). 
Se pensarmos por esse aspecto, aquilo que pesava para Gómez-Peña por ter sido imposto pelo imaginário nacional, passa a ser a proximidade dos limites perspectivizando os entrelugar es paradoxalmente invertidos pelo discurso hegemônico do Outro. Isto é, é como se o discurso do Outro sempre tivesse mais valor do que a minha historiografia local e, assim, eu não pudesse evidenciar a minha fala, verdadeiro testemunho existente fora do jogo de interesses.

Gómez-Peña identifica essa questão e começa a explorar, de maneira mais livre, aquilo que foi vazado no vocabulário intelectual do pensamento teórico geral e comenta:

Eu decidi voltar ao Southern Califas em 1993. Desde os distúrbios, Los Angeles transformou-se no epicentro das crises sociais, raciais e culturais da América. Ela foi, sem que se quisesse, a capital do crescente Terceiro Mundo dentro do Primeiro Mundo que se encolhe. Eu gostaria de ser ambos, uma testemunha e um cronista dessa maravilhosa loucura. $(1996, \text { p. } 64)^{5}$

Por essa sua arbitrariedade, ele provoca uma aproximação com o público e continua afirmando que a "identidade americana tem dependido historicamente de uma oposição a um outro, seja ele cultural, racial ou ideológico" [“American identity has historically depended on opposing an "other", be it cultural, racial, or ideological".] (p. 65), mas que, os próprios norteamericanos sentem-se vítimas dos imigrantes afirmando que "Se não fosse por eles, tudo estaria bem" ["If it wasn't for them, everything would be all right."] (p. 66).

Aceitando essa "invenção" de inspiração estadunidense, o autor comenta que é impossível não sentir medo, ou não se sentir alienígena, ou não enfrentar problemas sociais. $\mathrm{O}$ que marca essa posição é a intervenção, na prática, de Gómez-Peña intensificar suas viradas discursivas para atingir a totalidade de uma sociedade materialista pronta a se superestruturar em noções contraditórias a seu próprio discurso. Com isso, ele moderniza o que estava sendo pensado no outro extremo e parte da ideia de que, intercontextualizar as vivências, foi a diferença significativa para a liberdade do povo chicano e a sua própria, principalmente. 
Eles, os chicanos e outros latinos, enfrentam todo tipo de "estranhamento" em terras estrangeiras, segundo o autor. Inicialmente, definindo-se como uma sociedade sem fronteiras, Gómez-Peña argumenta que nesse processo de reconstrução histórico/cultural, o mexicano não vai voltar para o México, assim como o inglês não vai voltar para a Inglaterra. Chicanos/mexicanos e americanos precisariam, isto sim, aprender uns com os outros a língua, as histórias, a arte e a educação de uns e outros idealizando um caminhar juntos apesar das diferenças, dos medos e da raiva. Gómez-Peña afirma que, “Aos olhos dos xenofóbicos, qualquer pessoa com feições diferentes, pele escura, sotaque, roupas, ou um comportamento social ou sexual visivelmente diferente, é um alienígena" ["In the eyes of the xenophobes, any person with visibly different features, skin color, accent, clothes, or social or sexual behavior is an alien".] (p. 66).

Essa é uma outra questão que, de maneira hábil, é conduzida pela expressão criada por Gómez-Peña. O "alienígena” afastaria-se do atual estágio civilizado da humanidade; seria a consciência crescente da expansão dos limites conhecidos de pensamento, o sistema cosmológico para definir toda e qualquer diferença, o molde do limite de liberdade e descolonização do pensamento do outro, dentro de uma "sociedade sem fronteiras - a inevitável sociedade do próximo século" ["borderless society - the inevitable society of the next century".] (p. 70). Com isso, o autor veicula uma maneira de firmar sua fala e prossegue em um ritmo artístico de causar pânico a todo aquele que se acomode e não queira atuar em sua movimentação.

Todas as questões apresentadas nos capítulos anteriores são reforçadas pelo texto performático escrito em 1994 “NEWS FROM AZTLÁN LIBERADO” (p. 73 a 75) em que Gómez-Peña continua "distribuindo" notícias sobre as minorias ilegais, ou sobre a configuração geopolítica dos menos favorecidos num ensaio que rompe com os elos naturais 
entre língua e território. Para Gómez-Peña, estes dois elementos tanto refletem quanto determinam a posição dos chicanos em relação às duas nações: a norte-americana e a chicana. Para um oprimido, como é o caso de ser a minoria ilegal chicana, qualquer um deles se percebe dentro de um discurso do autor sobre raça, etnia e nação, informando sobre como os cidadãos mexicanos têm sido executados por gangs e, também, como têm sido deportados.

Gómez-Peña ainda comenta, nesse texto, que as deportações acontecem quando "todo gringo insubordinado" não leva "consigo a carteira de identidade" ["all insubordinate gringos who don't carry the national identity card”.] (p. 74). Parece, com isso, que o receio do autor enquanto estiver nos Estados Unidos seja o de que a superioridade concedida aos outros estrangeiros naquele país possa prevalecer sobre o poder da cultura local chicana e que a sua força, sempre crescente, não assuma posições paralelas aos mapas ocupados pelos norteamericanos. Nessa situação, todo trabalho do autor iniciado nas regiões fronteiriças, revela a série de hierarquias pelas quais ele tem passado tentando impor sua escrita. Gómez-Peña reconhece que seu jeito de pensar é bastante estratégico e, por meio de diferentes construções, leva-nos às noções de compreensão do paradoxo disciplinar imposto pela própria escritura. Lidando com todo tipo de consequências, ele reflete sobre o estado de sua arte e ataca atividades que não queiram sentir o desamparo quando se está em terras estrangeiras.

Fazendo distinguir sua "voz" de outras linguagens características do teatro, GómezPeña expressa, no capítulo nomeado “CHICANOST: RADIO NUEVO ORDEN” (p. 7778), sua opinião acerca de como lacunas históricas, artísticas e linguística s têm sido formadas a respeito de seu povo quando, por meio de metáforas, afirma que suas transmissões foram interrompidas por uma voz feminina, aquela demonstrando que ele "escreve" em conjunto com outros chicanos para fazer valer sua originalidade. 
Gómez-Peña cultiva seus interesses ideológicos de uma maneira tão ampla que ele os alimenta por meio dos mais variados círculos de produção profissional da arte. $\mathrm{O}$ autor participa da visão de que ter liberdade de expressão é metaficcionalizar quaisquer das formas de se falar sobre a própria subjetividade, seja ela transcrita em forma de personagem, autor, narrador, ou qualquer outra. Vivendo dessa maneira, Gómez-Peña costuma ser a imagem da imagem de si mesmo, a obra de arte inserida no contexto histórico da crítica que também o enfatiza. E mais: seu discurso de autenticidade é considerado pelas mais variadas instituições assim como pelos círculos mais restritos dos acontecimentos ficcionais. Gómez-Peña é um acontecimento contemporâneo, pois sua estrutura textual é uma mistura do contexto historiográfico com o romanesco da performance, iniciativa que inclui as demandas do povo mexchicano.

Portanto, cada qual poderia ouvir a "voz de seus outros selves", assim como "as vozes de seus ancestrais", para que se pudesse conceber interpretações sobre o próprio espaço e as atividades intelectuais do Outro ["you can listen to the voice of your other selves / \& to the voices of your ancestors"] (p. 78).

Para adentrar e anarquizar um pouco mais sua escritura, Gómez-Peña nos presenteia com uma crônica escrita em 1995, sob o título de “COLONIAL DREAMS/POSTCOLONIAL NIGHTMARES - A Chronical of Performance Projects (1979-1995)” (p. 80 a 109). Aqui ele nos leva a distinguir as diferentes formas de escrever, assim como marca sua irreverência ao narrar suas próprias experiências quando encena sua arte não apenas no palco, mas em qualquer outro lugar público.

A liberdade suprime o produtor. Mais uma vez, os suportes para conceituar suas propriedades estão nas veredas de questionamentos sobre de quem é a autoridade em encenar, ou de quem é a ideia de escrever, ou, ainda, de quem são as bem-humoradas palavras 
proferidas por suas personagens. "Na minha arte, eu exploro os labirintos da identidade, as intersecções da linguagem, e os precipícios da nacionalidade”, afirma o autor ["In my art I explore the labyrinths of identity, the intersections of language, and the precipices of nationality”.] (p. 80). Gómez-Peña se desvela em ser um crítico perspicaz, um desconstrutor de antigas verdades que, agora, devem destacar-se a partir de seu enfoque particularizador.

As convenções pretéritas da arte mudam em suas mãos e os comentários que ele tece sobre a força da herança chicana apresentam-se em forma de razão-dominação, contradizendo a hegemonia do Outro.

Nesse texto, ele nos conta como é encenar, ou melhor, passar pela experiência de se dizer o último dos indígenas de uma determinada tribo "um exótico espécimen multicultural" [“an exotic multicultural specimen”] (p. 99). Em exposição dentro de uma gaiola em um hall de hotel, ele rompe o espaço da linguagem teatral e mostra outros aspectos da arte de encenar. Gómez-Peña faz demonstrações de “preservativos pré-colombianos" ["pré-Columbian condoms"], entre outras ousadias (p. 100), enquanto sua amiga Coco Fusco conclamava a audiência para entrevistá-los.

Mas isso não é tudo. Gómez-Peña propõe que a linguagem do teatro seja múltipla, assim como ele é um "bruxo da fronteira" [“Border Brujo"] (p. 92), invertendo identidades e fazendo experiências com o público espectador (p. 92 a 95).

Dessa forma, sua postura diferente é o constante empenhar-se em afirmar que "o show continua" ["And the Show Goes On"]; ele próprio informando que incorporou às suas demonstrações "novas tecnologias (um componente da Internet, uma página na Web, e um CD-ROM)", como uma forma de inovar para chocar o público ["new technologies (an Internet component, a Web page, and a CD-ROM)"] (p. 108). Vemos que sua posição abre possibilidades de novos dizeres sobre o sentido de sua experiência, tanto quanto sua arte 
chega a atuar como uma contestação, sempre, em defesa das histórias e das problematizações referentes à representação da cultura chicana.

Simbolizando mais uma vez os acontecimentos no palco, Gómez-Peña dispõe com "NAFTASTEC: PIRATE CYBER-TV FOR A.D. 2000" (p. 111 a 125), uma bizarra transmissão televisiva sobre a cultura e a identidade dos norte-americanos. Menciona os "bandidos ciber" ["cyber bandits"], assim como o "ciberespaço" [“cyberspace"] (p. 111) e se autonomeia “O Naftaztec", um tipo de "vendedor transcultural, disc-jockey apocalíptico, e um bandido das super highway da informação, todos em um, e vice-versa, interrompendo seu coito, como sempre" ["My name is El Naf-taz-tec: cross-cultural salesman, disc-jockey apocalíptico, and information superhighway bandido, all in one, within, \& vice versa, interrupting your coitus, as always".] (p. 112).

Nesse ponto e por todo o capítulo, aparecem significações informando sobre os sentidos que por nós são apreendidos com esse tipo de transmissão entrecortada por projeções fílmicas, transmissão radiofônica e "falas” em diversas línguas.

Nesse momento, a imagem muda e o choque provocado em nós nos faz perceber que o autor se refere a voltar à idade de ouro do multiculturalismo, como também, "a identidade americana" ser "um jogo sujo" [“American identity is a messy business"] (p. 114).

Trata-se, por outro lado, de percebermos a controvérsia com a qual nos deparamos ao identificarmos que duas personagens no palco, o Naftasteca e o Ciber-Vato ["El Naftazteca and Cyber-Vato"], discutem sobre aquilo tudo ser ou não "realidade virtual" ["of a virtual reality"] (p. 120).

Nesse intrigante momento, as possibilidades de intromissão nos diferentes aspectos da vida chicana costumam representar posições ideológicas reinando em outros limites discursivos. A América para Gómez-Peña é o enredo visível para uma explicação de 
acontecimentos morais especificamente referindo-se ao cotidiano chicano. $\mathrm{O}$ artista interage com as vítimas dessa visão única e nos dá a alternativa de que, de forma consciente, seus debates têm gerado múltiplas manifestações de sentido entre o que ele apresenta no palco e o mundo enfrentado fora da sala de espetáculos.

Por outro lado, no outro extremo, não obstante ter mencionado as discussões entre as personagens, o capítulo termina questionando sobre a identidade de cada um, não das personagens, mas do espectador. Fica, também, a dúvida se "pessoas de cor poderiam ter mais acesso à alta tecnologia” [“Should people of color have access to high technology?”] (p. 124). De acordo com Yúdice,

\begin{abstract}
Surpreendentemente, ao final do ensaio sobre a tecnologia, Heidegger acalenta a possibilidade de que uma vez que a tecnologia tenha tomado tudo em todo lugar, "a essência da tecnologia pode advir à presença no acontecer da verdade". Para que isso seja possível, a reflexão sobre a tecnologia, ele nos diz, precisa acontecer "numa esfera que seja, por um lado, familiar à essência da tecnologia e, por outro, fundamentalmente diferente dela". Essa esfera de reflexão, ele acrescenta, é a arte. Todavia, se a essência da tecnologia impregnou todas as coisas, impondo-nos a percepção da arte por meio da estética, então "tanto mais misteriosa se torna a essência da arte". (2004, p. 49)
\end{abstract}

Como vemos, o paradoxo está em que, quaisquer tentativas de emancipação sejam elas artísticas, sociais ou culturais, ainda segundo Yúdice, "parecem retroalimentar o sistema a que resistem ou se opõem" (2004, p. 49).

As experimentações de Gómez-Peña no teatro continuam com outro texto performático escrito em 1955, “BORDERAMA” (p.127 a 153).

O conjunto das atividades começa com o povo sendo conclamado a comparecer vestido com suas roupas favoritas, "prontos para expressarem as fantasias inter-raciais que todos temos dentro de nós" ["ready to express those interracial fantasies we all have inside of us".] (p. 127). A partir daí, as cenas são intercortadas com projeções de slides, em cuja cena inicial são apresentadas galinhas no palco mais um esqueleto crucificado, entre outras 
inovações. A essa experimentação ele deu o nome de "Perigoso Jogo da Fronteira" ["The Dangerous Border Game"] (p. 128).

Mais uma vez, ele se utiliza da metáfora sobre fronteiras para indicar a diferença e a desigualdade social encontradas ali. Numa época em que qualquer inserção ideológica abrange lutas entre passado e presente, Gómez-Peña inclui em seu discurso a raça (o nativo, o branco e o estrangeiro), a sexualidade e a classe social de cada um residindo na fronteira, e os problemas enfrentados por todos eles nessa trama. Ele profetiza:

\footnotetext{
Mas agora, raça,

você está prestes a testemunhar um milagre no palco

um ato de identidade em fuga nunca apresentado antes para uma audiência ao vivo

um hispânico que, tendo perdido seu caminho para Aztlán,

experimentará uma conversão bem aqui, no palco. $\left(1996\right.$, p. 130) ${ }^{6}$
}

Então, falando ao megafone com a voz filtrada por uma máquina SPX, ele declara querer ir para a cama com uma mulher branca, uma loira germânica (p. 130-131). Depois, chama os espectadores para subirem no palco e Roberto Sifuentes vai até a plateia para encontrar uma voluntária a fim de bater em Gómez-Peña. O fato se consuma e o autor afirma que suas canções vão além de sua vida sexual e comenta que seu diretor de cinema preferido é Wim Wenders e não Roberto Rodriguez. Também afirma:

Sim, eu prefiro Rage Against the Machine à Banda Machos

Sim, eu prefiro Annie Sprinkle a Rubén Martinez

O que há de errado comigo?

\section{O que há de errado com ele?"}

Eu ajo como se tivesse nascido em Pasadena ou New Jersey de uma família desfuncional de origem inglesa

\section{O que há de errado com você?}


Aceita, mano! Você é um simples artista Taco Bell performático,

Um aborto do telemundo ... (1996, p. 132-133) ${ }^{7}$

Nessa conjuntura, para ilustrar sua função de narrador, Gómez-Peña aponta o fato de sempre esclarecer seus ideais e se envolver com o olhar de recusa do norte-americano que tanto tem incomodado sua etnia. E, com essa forma crítica de ver as coisas, está a exigente e egocêntrica maneira de informar sobre os próprios anseios e sobre a situação econômica e política da América nessas últimas décadas.

Nesse ir e vir do texto, nós nos adaptamos às suas descrições e compreendemos que sua própria história foge ao controle de sua escrita, sempre arrancada conforme seu desejo. "Nesses tempos de dor emocional aguda e confusão política, nós sempre encontramos refúgio na nostalgia, mas algumas vezes, mesmo a nostalgia é difícil de encontrar, e isso é o porquê você vai ao terapeuta", exclama ele ["In these times of acute emotional pain and political confusion, we often find refuge in nostalgia, but sometimes even nostalgia is hard to find, and that's why you go to the therapist".] (p. 136). Segue daí que seu conhecimento e seu trabalho multiplicam o processo de criar novos estilos de vida, novos movimentos culturais.

Inquietante também neste capítulo é o seu expressar-se formalizando o objetivo de continuar sua jornada sempre em direção ao Norte. Por essa série de detalhes, ele acrescenta que precisa passar por "Phoenix, Denver, Detroit, Big Smoke, Chicago, si ... cago ... ainda em espanhol" ["I hit the road again [...] through Phoenix, Denver, Detroit, Bigg Sssmoke, Chigago, si ... cago ... in Spanish still”.] (p. 140).

Ao colocar essa imagem, Gómez-Peña caracteriza a intersemioticidade da linguagem teatral presente na hibridização da já incorporada essência da própria linguagem dramática. Ele reconstrói o fundamental para explorar as possibilidades de construção que a linguagem da dramaturgia permite, e também não abandona as influências vanguardistas de décadas anteriores, mas sim, acrescenta-lhes um caráter escritural que se aproxima das artes cinéticas e 
da filosofia. Com essa escolha, ele tem acesso ao não linear do conteúdo, ao texto híbrido que vem sendo chamado de interatividade.

Fechando de certa forma o ato dessa apresentação, ele menciona, no slide 4, a "CENA DE HERNAN CORTEZ \& A MALINCHE PRESTES A FAZEREM SEXO” [“SCENE OF HERNAN CORTEZ \& LA MALINCHE ABOUT TO HAVE SEX”], argumentando que "os mexicanos entendem claramente o poder da sedução erótica" ["Mexicans clearly understand the power of erotic seduction”.] (p. 143). Tendo o corpo como algo disponível, é como se Gómez-Peña visse as ilimitações efetivas da posição de um sujeito que pode se perguntar “de quem é esse corpo", colocados em cena pelo movimento do próprio desejo? Em seguida, transformando sua atuação no palco diz que "Cortez não sabia para onde estava indo ... a criação de toda uma nova raça! Os filhos da Chingada ..." [“Cortez didn’t know what he was getting into ... the creation of an entire new race! Les enfants de la chingada ...”] (p. 143144).

A partir daí, nos é apresentada a sequência conotando a sua frase de que "os mexicanos sempre foram criaturas migratórias" ["Mexicans have always been migratory creatures".] (p. 144) e que ele estaria tendo uma "crise de identidade no palco" ["I'm having an identity crisis on stage”] (p. 151). Novamente, o autor indica os tipos díspares resultantes de realidades híbridas. Já não é imprevisível; sua fragmentação comprova as particularidades migratórias.

Trata-se, agora, de Gómez-Peña enfrentar áreas periféricas, a travessia que engloba e transcende toda uma visão econômica, política e geopolítica da chicanicidade estabelecida até então. Contextualizando um novo regime de sociabilidade, o autor prevê as perspectivas advindas não só de uma economia política, mas, também, de uma subjetividade evolutiva. O autor emerge de um ponto de vista biotecnológico e dá origem a uma produção de natureza 
intervencionista baseada em redes de comando e de controle, caso específico dos fenômenos técnicos que aparecem em suas cenas dramatizadas. Ele pergunta:

\author{
Existe alguma pessoa do museu aqui? \\ Alguém do Museu da Tolerância, talvez? \\ Vocês nos aceitariam como parte de sua coleção permanente? \\ Um vivente, moribundo, autêntico diorama mexicano, \\ ou vocês prefeririam ver mais ação: Ok, \\ Roberto, adote uma cena e congele. \\ Cena quatro, tolerância zero, ação. $\left(1996\right.$, p. 152) ${ }^{8}$
}

Na polêmica cena seguinte, ele e Roberto Sifuentes, em slow motion, degolam frangos dizendo "Chick, chicken, Chicano ... Power!” (p. 152).

As luzes se acendem, eles se sentam na borda do palco e mantêm conversa com a plateia. Esta aplaude, eles se levantam e comentam que "O SHOW CONTINUA" ["AND THE SHOW GOES ON”] (p.153).

Seguindo esta linha de raciocínio, em seu texto performático de 1955, “A SEMINAR ON MUSEUM RACE RELATIONS”' (p. 155 a 160), Gómez-Peña continua tendo diálogos com os espectadores e pede que eles sejam sinceros ao responderem as perguntas que lhes forem sendo feitas durante o espetáculo. Satisfeito com as respostas, ele agradece novamente pela sinceridade e diz que "Isso é a América" ["Thanks again for your sincerity. That is America”.] (p. 157).

Depois, marcando o centro de sua apresentação, ele questiona se Arte é "apenas para entreter, decorar a casa ou criar imagens positivas de uma cultura oprimida" ["art must only entertain, decorate your home, or create positive images of an oppressed culture"], e mais, se na audiência "há alguém que secretamente tem a fantasia de ser de uma raça ou de uma nacionalidade diferente" ["Are there any people in the audience who secretly fantasize about being from a different race or nationality?'] (p. 157). 
Daí a importância da memória, de um lugar destinado à comemoração ou à revelação da raça chicana, pois, ser de uma raça diferente é também partilhar responsabilidades pertencentes às duas culturas: à nativa e à estrangeira.

Sendo assim, Gómez-Peña procura criar a sua maneira de comunicação quando dinamiza a plateia e introduz, pelo acordo com ela, um encontro para abordar aspectos problemáticos referentes à integração cultural de ambos os países, o México e os Estados Unidos.

As perguntas continuam e ele faz as seguintes colocações: "É verdade que os Latinos são bons amantes?” [...] “O que é um chicano?”, [“Is it true that Latins are good lovers?” [...] “What`s a Chicano?”]; e para o "alienígena à esquerda: você tem uma carteira de identidade de estrangeiro?" [“To the alien on the left: Do you have a green card?"] (p. 158).

Como uma chave para decodificar esta realidade, Gómez-Peña provoca a plateia com duas últimas perguntas: “Qual a diferença entre um mexicano e um cubano?”, e, “quantos artistas mexicanos são necessários para lotar um teatro como este?" ["What's the difference between a Mexican and a Cuban, eh?! [...] How many Mexican artists does it take to fill up a theater like this, eh?!’] (p. 159).

A cena termina e, com isso, fica a impressão de estar coroado de êxito mais um dos infinitos questionamentos de Gómez-Peña: o que é possível fazer para se resolver tantos problemas?

Sua dramatização acabou de impulsionar, mais uma vez, o movimento para se encontrar uma nova direção, um movimento que leve muito além das propostas de acomodação a um sistema cujos efeitos perniciosos deveriam ser atenuados por outros artistas com iniciativas dessa mesma importância. Preocupado em manter essa posição de esquerda, Gómez-Peña participa de foros de discussão e busca interagir com todas as formas de engajamento. 
Em uma carta a um "ex-amigo" escrita em 1994, intitulada “ON U.S./MEXICO RELATIONS: From the Battle of EI Álamo to the Signing of NAFTA”(p. 161 a 164), ele marca as diferenças de opiniões entre si mesmo e o "outro" quando afirma o seguinte: "Eu chamei você de "gringo" carinhoso / você chamou-me "minoria" duas vezes / é claro que não quisemos significar isto / mas de qualquer forma fomos amaldiçoados pela História" ["I called you "gringo" de cariño / you called me "minority" twice / we didn't mean it, of course / but we were somehow damned by History".] (p. 161).

Assim, criando mais um tropo de experimentação, Gómez-Peña apresenta os conflitos dormentes em sua alma. $\mathrm{O}$ autor comenta que precisa de terapia, além de mencionar que "há um poder inquestionável em ser reservado" ["there is unquestionable power in being reserved”], e continua o monólogo citando: "você pontuou que o multiculturalismo estava / certamente morto / Eu respondi que você estava evitando problemas cruciais / da raça [...] você então deu muita importância à ecologia / enquanto eu coloquei muita ênfase sobre a imigração" ["you pontificated that multiculturalism was / rightfully dead / I replied that you were avoiding the crucial matters / of race / [...] you then placed too much importance on ecology / while I put too much emphasis on immigration”.] (p. 162).

Algumas dessas suas ideias acabam influenciando, embora de maneira indireta, as políticas partidárias encontradas na plateia e, uma vez que esse fortalecimento precisa de um empurrão para continuar se disseminando, Gómez-Peña não hesita em contribuir com os moldes de sua política para legitimar mudanças.

Reencontramos, portanto, conexão entre imagem e texto, entrecruzando, teoricamente, o problema da significância em sua escritura. Vale mostrar, dessa maneira, que outras imagens estão presentes nessas passagens:

Eu pensei comigo: "esse ex-menino doce, güerito liberal

é na verdade um contestador daqueles", mas eu engoli 
minhas palavras

você então insistiu que eu era um mero símbolo para os liberais

brancos

Eu lembrei a você que mais da metade da minha obra

acontecia em lugares chicanos/mexicanos

você disse "isso não é bom o suficiente"

Eu respondi sarcasticamente, "claro, nunca somos bons

o suficiente

você me quer de volta às margens

onde ninguém pode ouvir minha voz, não é?”. (1996, p. 163) ${ }^{9}$

Como vemos, essa "fala" cria uma cultura militante, uma forma exclusiva de contestações, uma contracultura na corrente das diferentes gerações. Gómez-Peña alude à luta social e política e nessas relações de produção encontra a reprodução da vida (real e imaginária).

Como para ele, também um dramaturgo, o "palco" não tem limites para suas significações, em seu poema “15 WAYS OF RELATING ACROSS THE BORDER” (p. 165 a 167), Gómez-Peña inova seu desdobramento dramático e apresenta quinze reflexões sobre o que existe entre ele e o Outro. $\mathrm{O}$ autor sugere incertezas, declara absurdos, volta-se para os exageros da seguinte maneira:

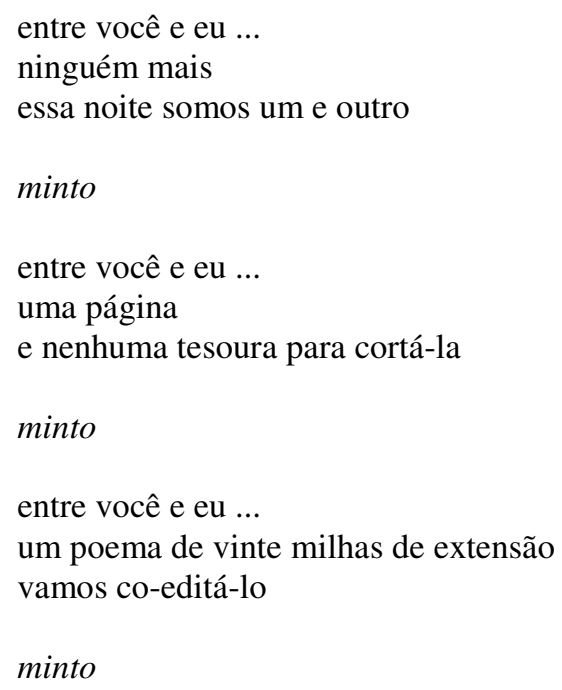


entre você e eu ...

uma faca apontando para mim

e você sequer sabe meu nome

minto

entre você e eu ...

um acordo fundamental

dois mais dois igual a vinte

minto

entre você e eu ...

bilhões de moléculas

e nada a ser feito sobre isso

minto

entre você e eu ...

uma galeria de hormônios

vem visitar-me à noite

minto

entre você e eu ...

uma espiral cadente

dancemos

minto

entre você e eu ...

um outro você e eu

trocando de parceiros

minto

entre você e eu ...

um abismo político

querido, nem sequer perca seu tempo

minto

entre você e eu ...

meu pênis iridescente

parafraseando o cordão umbilical

minto

entre você e eu ...

uma selva de absurdos

vamos nos encontrar qualquer outro dia

minto

entre você e eu ...

um massacre de animais

\& seria melhor você me dar uma explicação

minto 


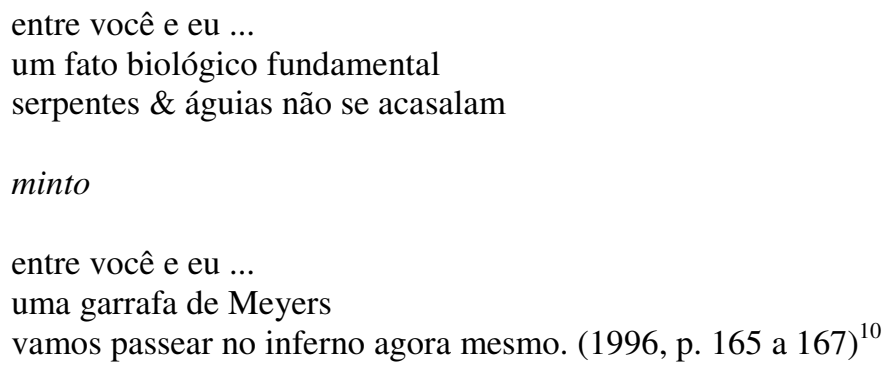

Gómez-Peña termina o poema apresentando um cartaz onde se lê que os imigrantes devem tomar precauções e estar atentos, pois tem morrido muita gente atropelada ao "cruzar" as "autopistas" ["En los últimos seis años más de 140 personas migrantes han muerto al cruzar nuestras autopistas durante la noche".] (p. 167).

O seu ensaio escrito em 1995, "DANGER ZONE: Cultural Relations Between Chicanos and Mexicans at the End of the Century" (p. 169 a 178), é concebido formalmente com um outro cartaz em cuja página inicial somos conclamados a fazer uma corrida pela fronteira, em um "Terreno Perigoso / Zona Perigosa" ["Terreno Peligroso/Danger Zone"] (p. 169).

Este ensaio faz parte de um projeto performático binacional em que artistas tinham por objetivo, "criar arte juntos" ["to create art together"], uma vez que "arte de fronteira é colaborativa por natureza" ["border art is collaborative by nature"] e, ainda desejavam mais: "abrir a caixa de Pandora das relações entre Norte e Sul" ["to open Pandora's box of North/South relations"], assim como "destruir tabus" ["to destroy taboos"] (p. 169).

Aqui, Gómez-Peña destaca a verdade multifacetada de não se ter mais certeza de nada, tanto quanto perceber que os norte-americanos também sofrem de uma crise de identidade. Isto não permite aos norte-americanos enxergar os negros e os chicanos. Mais ainda: a subordinação geral a que os chicanos se negam a se submeter já faz parte não apenas de uma cultura local mas de programas de intercâmbio global. É consenso comum que esse sujeito 
chicano não aceite ser privado da liberdade de falar a partir de vários lugares como forma de conclamar os outros para participarem de uma política de superação de desigualdades.

Assim, segundo o autor, fica a impressão de que, para os chicanos, "nossa única comunidade verdadeira é a televisão" ["it seems that our only true community is television"], assim como "talvez, nossa única nação real também seja a televisão" ["Perhaps our only real nation is also television".] (p. 172).

Os chicanos sentem-se perplexos em decorrência de todas essas questões existenciais e se declaram "uma cultura de resistência" ["We define ourselves as a culture of resistance".] (p. 175). Para aqueles que tentam voltar para o Sul levando sua arte, resta a frustração de se verem rejeitados pelos próprios irmãos mexicanos (p. 175).

Falando em defesa de sua arte, o poema “DES-ENCUENTRO DE 3 MUN-2", escrito em 1992 (p. 179-180), representa a perspectiva em que um jogo de palavras cobre todo o universo poético desse artista. Sem deixar de comentar sobre a fronteira, ele se atribui a possibilidade de nunca apreender um conhecimento global e acabado. Os elementos estariam sempre em evolução, sempre produzindo considerações de novos sentidos.

Gómez-Peña continua, com isso, dispensando tratamento modernizador à sua fala. Aquilo que ele propõe incluir em suas declarações oferece certo tipo de conquistas identitárias explicando que a sociedade chicana deixou de ser colônia há muito tempo, e que ela globalizou-se para defender sua própria identidade. Assim, a opção escolhida pelo autor é a de diferenciar-se em se promover como o marco artístico de grandes debates políticos tanto consigo mesmo, quanto com seus espectadores. Por isso, Gómez-Peña procura basear suas narrativas na experiência concreta do que foi vivido. Ele reconhece os pontos principais dessa vivência e aproveita a experiência para ordenar suas performances. 
Vejamos, agora, a habilidade de Gómez-Peña em narrar. Numa crônica de 1994, “THE ARTIST AS CRIMINAL” (p. 182 a 187), é relatada a agressão física sofrida por ele e sua amiga Coco Fusco, quando representavam uma versão do projeto "The Guatinaui World Tour", em Buenos Aires.

Ele foi atacado por uma misteriosa personagem que apareceu não se sabe de onde e jogou ácido em seu estômago. O autor descreve, a partir daí, o ataque que outros colegas também sofreram, assim como incorpora, em sua narrativa, o desenrolar dos acontecimentos quando colegas são presos por fazerem um filme sobre os chicanos. Os policiais afirmam que aquelas pessoas estavam fazendo política ao invés de arte e não adiantava contestarem porque "Hugo Sánchez estava sob suspeita de ter "desrespeitado" a bandeira" ["Hugo was being charged with a federal offense [...] and of the sacrosanct "bloodstained" flag".] (p. 184). Hugo foi levado pelos policiais e estes diziam-lhe que em breve "regressaria para seu país" ["he would return to his country”.] (p. 185). Hugo não entendia como autoridades do PGR tinham entrado em contato com agentes da imigração mexicana e que "juntos tinham decidido que o artista vivia no México ilegalmente" [they decided that the artist was "illegally" dwelling in México"(p. 185).

A solução do problema veio de maneira penosa e dramática. Gómez-Peña atribui essa confusão toda à "intolerância da polícia por cultura alternativa" ["the police’s intolerance for alternative culture"], e às "pesadas restrições sobre liberdade de expressão no México" ["the heavy restrictions on freedom of expression in México"] que "definitivamente contribuíram para o pesadelo de Sánchez” [“definitely contributed to Sánchez's nightmare”] (p. 187).

Diante desse cenário, o autor ainda comenta: "O caso de Hugo Sánchez é único: um mexicano deportado para os Estados Unidos por fazer performance. Por quê? Talvez isso tenha a ver com o contexto politicamente pesado. Foi uma época extremamente tensa em Tijuana" [Hugo Sánchez's case is unique: a Mexican deported to the United States for doing a 
performance. Why? Perhaps it had to do with the politically charged context. It was an extremely tense time in Tijuana".] (p. 186). Segundo Canclini,

\begin{abstract}
Outros artistas e escritores de Tijuana desafiam o tratamento eufemístico das contradições e o desenraizamento que observam em La línea quebrada/The broken line [a revista do Taller de Arte Fronterizo]. Rejeitam o elogio das migrações causadas pela pobreza na pátria e nos Estados Unidos. Os tijuanos nativos ou que tenham morado ali durante quinze anos ou mais se sentem ofendidos pela insolência das paródias despreocupadas desses artistas: "são pessoas que acabam de chegar e imediatamente nos dizem quem somos e como deveríamos nos descobrir a nós mesmos. (1992, p. 42)
\end{abstract}

De acordo com a afirmação acima, podemos admitir que as identidades fronteiriças se multiplicam em forma de narrativas e alcançam outras categorizações à medida que vão se locomovendo de um lugar a outro. Sendo assim, as identidades incrementam o ritmo da descentralização do poder do outro.

Queremos lembrar que em “DEDICATORIAS", texto performático para transmissão radiofônica escrito entre 1990 e 1993 (p. 188-189), Gómez-Peña manifesta a importância de o sujeito artístico atribuir relevância aos fatos histórico-culturais de seu povo, ou seja, as mudanças acontecem e a desigualdade parece estar mais reduzida, pois o povo chicano apropriou-se de alguns bens considerados de interesse comum, como as lutas contra a injustiça econômica, por exemplo. Nesse ponto, os movimentos de redemocratização social foram concebidos para que a expansão desse pensamento pudesse estender-se ao ilimitado mercado comunicacional, e tenha o apoio de todo cidadão. Devemos apontar aqui, as evidentes iniciativas de ação de cidadania levadas a cabo por Gómez-Peña. Ele termina o texto com uma pergunta relevante: "Por que 'vocês' [a plateia] estão tão assustados ‘conosco'? [Why are “you” so scared of “us”?”] (p. 189).

Lutando para mostrar seus valores, Gómez-Peña continua seu objetivo de "se fazer ouvir" e com seus "TRADITIONAL BOLEROS ..." ("BÉSAME MUCHO”, música de 
1995, e, “EL REY DEL CRUCE”, música de 1991), atribui um suporte formal acrescentando a música ao seu discurso.

Nessa encruzilhada, ele amplia as possibilidades de elaborar novas realidades, modificando o meio e aplicando lições que promovam uma nova consciência. Gómez-Peña comenta que "não se tem de cruzar primeiro / mas há que saber como cruzar" ["que no hay que cruzar primero / pero hay que saber cruzar".] (p. 190). Compartilhando dessa pluralidade encontram-se os vários processos desiguais e simbólicos de modernização empreendidos pelo autor em seu discurso. O gozo estético e a sensibilidade advindos daí ficam a cargo daquele que assegura a distinção de ambos os lados.

Acumulando ideias e forças, Gómez-Peña ambientou-se a uma cultura militante. Ele estuda expressões culturais como instrumentos de conhecimento, tanto de estruturas sociais quanto de organizações políticas.

Com seu discurso inovador, o autor inclui em sua obra um poema épico que ele afirma estar “em andamento", escrito em 1993, chamado “THE LAST MIGRATION: A Spanglish Opera (in progress)" (p. 193 a 236).

Ele comenta que para representar esse texto seria necessário um elenco de mais ou menos quinze artistas entre atores, dançarinos, cantores de ópera, músicos clássicos, além de roqueiros.

O texto é um composto de trinta e cinco poemas em que percebemos a origem multifacetada do seu trabalho, e vemos uma complexa inter-relação temática destacada nos seguintes comentários: "Instrução para encarar o fim do século" ["Training to face the end of the century"] (p. 194); “os brutos também amam" ["los chucos también aman"] [...] "morrer é dramatizar o último strip-tease" ["to die is to perform the last strip-tease"] (p. 195); "sangro, logo existo / parto, logo sou / sou / sou porque somos" ["sangro, luego existo / parto, 
luego soy / soy / soy porque somos"] (p. 196); "Santo Dollariego, dono das migras e dos carrascos / roga por ti mesmo, fundilho” ["San Dollariego, patrón de migras y verdugos / ruega por ti mismo culero”] (p. 198); “Santa Rosa, Mãe do Crime Letal / livra-nos das balas anônimas” [“Santa Rosa, Madre del Crímen Letal, / líbranos de las balas anónimas”] (p. 199); “querida X mascarada / rainha dos caminhos bloqueados / esta é uma canção de amor para você / a última" ["dear X enmascarada / reina de los caminos bloqueados / this is a love song for you / la última”] (p. 200); "gritar em inglês / [...] recordar em espanhol / orar em línguas mortas [...] signos todos da Nova Identidade" ["to cry en inglés / [...] recordar en español / orar en lenguas muertas [...] signos todos de Nova Identidad"] (p. 202); "busco a morte da identidade / a última fronteira do ocidente" ["busco la morte de la identidad / la última frontera de occidente"] (p. 203); "sou poeta dos molhados" [“que ío soy poeta de mojados"] (p. 205); "sugiro que você morra no Brasil / na última noite de Carnaval" ["I suggest that you die in Brazil / on the last night of Carnival"] (p. 206); “então continuamos a fazer amor como coiotes amedrontados / até que fosse hora (para um de nós) sair mais uma vez" ["so we kept making love like frightened coyotes / 'til it was time (for one of us) to part once more"] (p. 210); "estou aqui/ali ["I am here/there"] (p. 213); "minha identidade está um pouco inflamada" ["mi identidad esta um poco inflamada"] (p. 215); "todo garoto americano com enormes armas e pequenas aspirações" ["all American boys with big weapons \& small aspirations"] (p. 216); "eles me odeiam ainda mais / por escrever assim" ["they hate me even more / I write like this"] (p. 217); "Ele veio para a América para tirar vantagem de nossa inocência" ["he came to America to take advantage of our innocence"] (p. 219); "perdemos a paciência histórica / estar e esperar não é suficiente" ["hemos perdido la paciencia histórica / estar y esperar no es suficiente"] (p. 221); "você sabe, vivemos uma crise permanente" ["you know, we're living a permanet crisis"] (p. 223); "portanto, a estrada foi minha salvação" ["thus the road was my salvation"] (p. 229); "minha voz real é ... / nem minha tampouco" 
[“my real voice is... / not mine either”] (p. 231-232); “jaina. A última vez que abri suas pernas / por um segundo eu vi o fim do mundo" ["jaina. the last time I opened your legs / I saw the end of the world for a second"] (p. 233); "a identidade congelada assim - / até que a Morte nos visite"[“la identidade así congelada - / hasta que la Muerte nos visite"] (p. 236).

À medida que enumeramos essas manifestações, fica configurado um tipo de necessidade de Gómez-Peña em dominar sua atualização performática. Para ele, quebrar estereótipos é mudar todo o aspecto da narrativa ficcional e se sobrepor aos demais discursos marcados pelo verossímil. É acrescentar uma fonte histórica de interações entre a cultura visual, as elites, e o popular. Para Gómez-Peña, o teatro mescla os meios massivos de comunicação e dessa forma, basta saber usá-lo para ser admitido como o melhor argumentador, o melhor artesão de qualquer entalhe artístico.

Desse modo, nesse processo que reflete contradições próprias, ele não tem limites; dilui sua dinâmica comprovando a aplicabilidade dessa sua arte em analisar o momento sóciocultural contemporâneo. Mais do que ultrapassar conceitos, ele utiliza novas técnicas narrativas, rompendo fronteiras tradicionais. Gómez-Peña não é repetitivo ou sequer folclorizante. Ele elabora sua arte envolvendo a multiplicidade de questões contemporâneas.

Toda a gama de possibilidades inovadoras apresentadas por Gómez-Peña ao longo da obra termina com um poema escrito em 1994, intitulado "WHERE WERE YOU DURING ALL THOSE YEARS?”' (p. 238-239). Nele, uma contaminação ideológica exortando o povo a se "identificar" com a cultura latina é condição assumida pelo autor para que surja, mais uma vez, o compromisso de definir a sua luta por uma nacionalidade cultural chicana. Ele se pergunta o que fazer com as origens chicanas, mas reelabora ludicamente seu discurso.

Gómez-Peña comenta que estava "lá” quando nasceu e que dali, na verdade, começa seu processo de peregrinação pelos "lugares" por onde deverá passar para levar e definir suas 
estratégias de renovação. O autor afirma que se encontrava na América quando "soube a respeito do silêncio e da morte" ["thus I knew about silence \& death"], e que estava "lá quando Manhattam foi à falência" ["I was there when Manhattan went bankrupt"], e "quando os skinheads puseram fogo em turcos que estavam na Alemanha / e em egípcios que se encontravam na Espanha, e em roqueiros em Buenos Aires... / (me salvei por milagre)" ["when the skinheads were burning Turks in Germany / gypsies in Spain, and rockeros in Buenos Aires ... / (me salvé de milagro)"] (p. 238).

Embora por essa perspectiva vejamos uma plurissignificação em ultrapassar "fronteiras", o autor expõe que ocupa um espaço onde "não tinha outras opções ... / (era como jogar a roleta russa)" ["I had no other options... / (era como jugar a la ruleta rusa)".] (p. 239). Confinado a essas margens e precisando exercer sua ideologia a fim de fazer exigências políticas identificadas com sua identidade chicana, Gómez-Peña experimenta o gosto de ver e sentir,

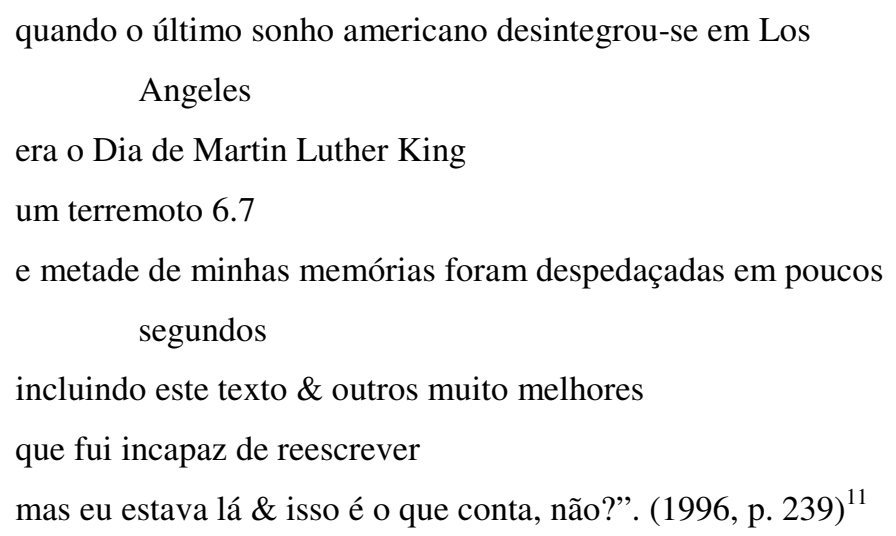

Reconhecendo todas essas "misturas" do mundo da ficção, a alternativa que o escritor vê para ocupar um novo espaço é justamente retomar suas origens de homem de literatura e criar uma fórmula em que uma nova ideologia é empregada num bilinguajar cheio de combinações inesgotáveis. Para Gómez-Peña, não se trata de manter a pureza da língua inglesa ou da língua espanhola para poder se expressar, mas de salientar que existe uma 
contaminação desta língua naquela e vice-versa. Um tratamento nada discreto sobre essa questão é levado muito a sério por ele, e, mais uma vez, o autor reflete sobre as relações entre arte e literatura, entre teatro e dramatização, entre os modos de significar ou ritualizar tudo aquilo que imaginava construir. Em outras palavras, ele faz lembrar com essa forma de produção, da assimetria existente entre as estruturas diacrônicas das línguas ocasionando o deslocamento de uma para a outra. De acordo com Mignolo,

O bilingüajamento, [...] não é precisamente o bilinguismo, em que ambas as línguas são conservadas em sua pureza, mas ao mesmo tempo em sua assimetria. O bilinguajamento [...], não é uma questão gramatical mas política, até o ponto em que o foco do próprio bilinguagismo é corrigir a assimetria das línguas e denunciar a colonialidade do poder e do saber. (2003, p. 315)

Gómez-Peña termina o poema com dois versos abrindo as possibilidades para questionar o leitor e celebrar sua ruptura com antigas convenções: "Fiz o melhor, realmente dei o melhor de mim ... / por falar nisso, onde você esteve durante todos esses anos?" [“I did my best, I did my very best ... / by the way, where were you during all those years?'] (p. 239).

\section{NOTAS}

1- "I hope of all my heart that this book will contribute to the sorting out of the great crises of our times, and to the mapping of more enlightened cartography for the next century. And I hope that despite its experimental nature, it won't become just another obscure text to be discussed by art theoreticians and cultural critics. It should speak to politicized artists, students, journalists, activists, teachers, technopirates, alternative rockeros, utopia thinkers, radical cultural organizers, anarchists, and border-crossers of all sorts - to anyone who is currently thinking out loud and fighting to recover the freedoms that our political and corporate classes have stolen from us so efficiently over the last fifteen years". (GÓMEZPEÑA, 1996, p. II)

2- "I see a whole generation / freefalling toward a borderless future / incredible mixtures beyond fiction: Cholo punks, pachuco krishnas, / Irish concheros, butoh rappers, cyber-Aztecs, / Gringofarians, Hopi rockers, y demás... / I see them all / wandering around / a continent without a name / the forgotten paisanos / howling corridos in Fresno \& Amarillo / the Mixteco pilgrims / heading North toward British Columbia / the Australian surfers". (GÓMEZ-PEÑA, 1996, p. 1)

3- "The art world is a dysfunctional family - a micro-universe reflecting the larger society. Artists and academicians rarely talk to one another. "Community artists" and politicized artists who work within major institutions still see each other as enemies, not as allies working on different fronts. Artists who work directly with troubled communities, such as the homeless, prisoners, migrant workers, or inner- 
city youth are viewed as opportunists, and their intentions are constantly called into question. "Successful" artists of color are perceived as having been "co-opted", or as "sell-outs". Those who venture into theory are accused of being elitists, not "organic" in relation to their community". (GÓMEZ-PEÑA, 1996, p. 14)

4- "Latinos and other people of color are regularly "mistaken" for "illegal aliens", gang members, drug dealers, and rapists, and often these "mistakes" lead to far more extreme resolutions such as incarceration, beatings by patriotic civilians or policemen, and depotations". (GÓMEZ-PEÑA, 1996, p. 55)

5- "I decided to return to Southern Califas in 1993. Since the riots, Los Angeles had become the epicenter of America's social, racial, and cultural crisis. It was, unwillingly, the capital of a growing Third World within the shrinking First World. I wanted to be both a witness and a chronicler of this wonderful madness". (GÓMEZ-PEÑA, 1996, P. 64)

6- "But now, raza, / you are about to witness a miracle on stage / an identity escape act never before presented to a live audience / a Hispanic who, having lost his way to Aztlán, / will experience a conversion right here, on stage" (GÓMEZ-PEÑA, 1996, p. 130)

7- "Yes, I prefer Rage Against the Machine to Banda Machos / yes, I prefer Annie Sprinkle to Rubén Martinez. / What's wrong wth me? / What's wrong with him? / I act as if I had been born in Pasadena or New Jersey / to a dysfunctional Anglo family. / What is wrong with you? / You are always pretending to be something you are not. / Accept it, bro! You're just a Taco Bell performance artist, / an abortion of telemundo ..." (GÓMEZ-PEÑA, 1996, 132-133)

8- "Are there any museum people here? / Anyone from the Museum of Tolerance, perhaps? / Would you accept us as part of your permanent collection? / A living, dying, authentic Mexican diorama, / or would you rather see more action: Okay, / Roberto, adopt a better tableau and freeze. / Scene four, zero tolerance, action!”. (GÓMEZ-PEÑA, 1996, p. 152)

9- "I thought to myself: "this ex-sweet, liberal güerito / is in fact un backlasher de aquellas", but I swallowed / my words / you then insisted I was a mere token for white / liberals / I reminded you that more half of my work / takes place in Chicano/Mexicano venues / you said, "that's not good enough". I I replied sarcastically, "sure, we're never good / enough / you want me back in the margins / where no one can hear my voice, que no?” (GÓMEZ-PEÑA, 1996, p. 163)

10- "between you \& me... / no one else / tonight we are each other / miento / between you \& me... / a page / and no scissors to cut it / miento / between you \& me... / a twenty-mile-long poem / let's coedit it / miento / between you \& me... / a knife pointing at me / and you don't even know my name / miento / between you $\&$ me... / a basic agreement / two plus equals twenty / miento / between you \& me... / billions of molecules / and nothing to be done about it / miento / between you \& me... / a tunnel of hormones / come visit me tonight / miento / between you \& me... / a downward spiral / let's dance / miento / between you \& me / another you \& me / exchanging partners / miento / between you \& me... / a political abyss / honey, don't even waste your time / miento / between you \& me... / my iridescent penis / paraphrasing the umbilical cord / miento / between you \& me... / a jungle of absurdities / let's meet some other day / miento / between you \& me... / a massacre of animals \& you'd better give me an explanation / miento / between you \& me... / a basic biological fact: serpents \& eagles don't mate / miento / between you \& me... / a bottle of Meyers / let's drive through Hell right now". (GÓMEZPEÑA, 1996, p. 165 a 167)

11- "when the last American dream crumbled in Los / Angeles / it was Martin Luther King Day / a 6.7 earthquake / and half of my memories were shattered in a few / seconds / including this text \& other much better ones / that I was unable to rewrite / but I was there \& that's what counts, que no?" (GÓMEZ-PEÑA, 1996, p. 239) 


\subsection{Imagens de Gómez-Peña em “The New World Border”: de um fragmento ao outro}

O sujeito apresenta uma história evolutiva embora, hoje, haja um crescente sentimento de desconforto a respeito de sua sorte. Quem é ele? A partir de que momento podemos perceber de que sujeito se trata?

Muito do que percebemos ou experenciamos em nossas vidas é a urgente necessidade de acreditarmos naquilo que nos faz identificar o sujeito como algo "vivo" e que nos faz viver. Além disso, a noção de sujeito ou de subjetividade dada pela internalização cartesiana do "penso, logo existo", começou a perturbar o espírito daqueles que identificavam outras singularidades descentradas e até um tanto desgarradas dessa perspectiva.

Partindo desse princípio, era costume percebermos o sujeito como "um indivíduo unificado, dotado das capacidades de razão, de consciência e de ação, cujo 'centro' consistia em um núcleo interior, que emergia pela primeira vez quando o sujeito nascia e com ele se desenvolvia" (HALL, 2003, p. 10 a 11).

As manifestações dessa categoria se dissolveram a partir do momento que aquela "existência" deixou de convir a outras essências e, implicitamente, a complexidade do mundo moderno exigia outras visões. A ideia de outro "ser" comportava outras ações e o sujeito pôde, então, ser encarado como um "eu" interagindo na sociedade. O fenômeno dava-se, portanto, em visualizar a essência como um "sujeito sociológico".

No entanto, essas condições vão provocar o aparecimento de um terceiro "ser", interativo, fragmentado, movendo-se, às vezes, confortavelmente, outras, nem tanto, de um lado para o outro, sempre em busca de suposições ou pressuposições partilhadas por alguns e não por outros e vice-versa. O sujeito, agora, "assume identidades diferentes em diferentes momentos, identidades que não são unificadas ao redor de um 'eu' coerente”. Surgia o sujeito pós-moderno (HALL, 2003, p. 13). 
A questão, pois, é suplementar essas relações e nos apropriarmos do conjunto do processo para assistirmos às evoluções pelas quais aquele sujeito resultou nesse que nos interessa.

Quando atingimos esse limiar, podemos afirmar a ocorrência de uma profunda transformação na natureza do sujeito. Ele, então, resiste em se individualizar (embora também seja uma figura de individuação), e atinge o ponto de manifestar-se em toda e qualquer possibilidade enunciativa, assim como em qualquer evento discursivo social, imageticamente, ou de forma camuflada, na tentativa de poder mostrar as infinidades de metamorfoses pelas quais tenha passado. $\mathrm{O}$ sujeito conserva, com isso, a imagem de uma experiência assegurada e definida pela própria condição humana de se representar como "várias identidades". Dessa forma, a desordem das consciências alardeia que estamos assistindo à morte do sujeito sob a rubrica da "crise de identidade". Investiga-se o aniquilamento da experiência subjetivizada para, depois, poder considerar-se as reflexões sobre ela.

Certamente, a pluralidade de caminhos que se abriu nessa constante busca para escapar do velho e familiar "eu", torna-se o produto de uma imagem que é, ao mesmo tempo, conflito e revolução. O sujeito enuncia-se formando um locus de subjetivação a partir do qual cria sua "posição" de sujeito pós-moderno. Por meio de "diferentes linguagens", os humanos problematizam sua constituição enunciativa, pois é por meio da linguagem que se torna possível a cada "falante" se constituir como sujeito do discurso. Assim, a excepcional força da subjetividade deriva tantos exemplos de liberdade sígnica quantas forem as enunciações a se transmutarem em particularidades discursivas.

É nesse agenciamento de tantas subjetividades, demonstrando de forma simultânea a "mistura" entre teatro e literatura, teatro e textualidade, que vemos surgir Gómez-Peña, recriador, com sua obra, de modalidades-limite da arte de encenar. O tipo de trabalho desenvolvido por ele é de tal forma inquietante, que, muitas vezes, as palavras soam 
desnecessárias e o murmúrio de um som, ou até mesmo o silêncio, é o bastante para ser compreendido. Se antes a arte cênica nos convidava a aceitar um tipo de texto linear $^{1}$ quando se queria falar em teatralidade, agora, Gómez-Peña codifica sua obra como "outra identidade", do começo ao fim.

Nesse sentido, podemos voltar um pouco no tempo e ouvir a resposta que foi dada por

Grotowski, na ocasião em que foi questionado sobre o texto teatral:

\begin{abstract}
Em uma de suas declarações, você disse que o teatro pode existir sem figurinos nem cenários, sem efeitos musicais ou luminosos - e até sem um texto. Você acrescentou: "No desenvolvimento da arte teatral, o texto foi um dos últimos elementos a ser acrescentado". Há, em sua opinião, um único elemento que o teatro não pode dispensar - o ator. No entanto, desde a Commedia dell'Arte existem dramaturgos. Deve o diretor de hoje desrespeitar uma tradição de diversos séculos? Que lugar você confere ao texto, como diretor?

Este não é o âmago do problema. $\mathrm{O}$ âmago é o encontro. $\mathrm{O}$ texto é uma realidade artística, existente num sentido objetivo. Ora, se o texto for suficientemente velho, e se preservou todas as suas forças para hoje - em outras palavras, se o texto contém certas concentrações de experiências humanas, representações, ilusões, mitos e verdades que ainda são válidas para nós, hoje - então o texto torna-se uma mensagem que recebemos das gerações anteriores. Todo o valor do texto já está presente, uma vez escrito: isto é literatura, e nós podemos ler peças como parte da "literatura". Na França, às peças publicadas em forma de livro é dado o nome de Teatro - um engano, em minha opinião, pois isso não é teatro, e sim literatura dramática. Diante dessa literatura, podemos tomar uma destas duas posições: ou ilustramos o texto, através da interpretação dos atores, a montagem, o cenário, a situação da peça, e neste caso o resultado não é teatro, sendo o único elemento vivo, em tal montagem, a literatura; ou ignoramos, virtualmente, o texto, tratando-o apenas como um pretexto, fazendo interpolações e modificações, e reduzindo-o a nada. Sinto que essas duas soluções são falsas, porque nos dois casos não estaremos cumprindo nosso dever como artistas, mas tentando cumprir certas regras - e a arte não gosta de regras. As obras-primas são sempre baseadas na transcendência das regras. Embora, é claro o teste se verifique na montagem. (1971, p. 39-40)
\end{abstract}

Tomando como foco de estudo essas considerações, podemos afirmar que a arte de

Gómez-Peña é uma arte de fronteira no seu movimentado continuum de rompimentos com o que foi denominado "arte estabelecida", na qual os textos eram dados para exprimir uma única possibilidade de interpretação. A performance de Gómez-Peña acaba por interseccionar caminhos e situações que antes não eram considerados e valorizados como arte. Da mesma forma, ela toca nos tênues limites que separam a vida da arte.

Com sua técnica borbulhante baseada na ontologia da Performance, ele desnorteia nosso espírito e atrai os humores descontrolados para dentro de seu discurso. Ele antes 
“sugere" por meio de gestos e sons, do que "representa", pois o seu universo de especulação está mais ligado ao fato de encarar a arte ao vivo, assim como a um tipo de "arte viva".

De certa forma, sua arte é o jeito de se colocar e de procurar uma aproximação com o espontâneo, com as incidências naturais, mais do que com o ato elaborado, ensaiado. Por meio de seu movimento de aproximação entre vida e arte, a Performance busca resgatar um tipo de prática radicalizada na qual se dá vazão a uma criatividade existencial e pulsional, baseada na transmutação de elementos do aqui/agora a fim de se poder expressar e ampliar as fronteiras da investigação artística e sua experimentação (COHEN, 2002).

Abertos a essa espécie de afinidade misteriosa, podemos inferir, então, as impressões que a linguagem de Gómez-Peña nos causa no texto performático "THE NEW WORLD BORDER: Prophecies for the End of the Century" (p. 21 a 48), um tipo de "existência", dilacerando nosso repouso.

Gómez-Peña inicia o texto afirmando que a obra "A FRONTEIRA DO NOVO MUNDO SEMPRE FOI DESCRITA POR COLEGAS e jornalistas como "arte chicana ciberpunk" e que de alguma forma [...] eu resolvi adotar a definição" ["THE NEW WORLD BORDER WAS OFTEN DESCRIBED BY COLLEAGUES and journalists as "chicano cyber-punk art" and at one point [...] I chose to embrace the definition”.] (p. 21).

A peça envolve apenas duas personagens: Gómez-Peña como "O ASTECA HIGHTECH" e Roberto Sifuentes como "SUPER-POCHO”. O figurino da primeira personagem é "maquiagem de ritual, um terno mariachi, um chapeu pachuco, brincos de caveira nas orelhas, um colete asteca, botas de couro de cobra, óculos terceira dimensão, óculos low-rider, bandana, luvas pretas, braceletes heavy-metal, e uma variedade de máscaras e perucas" ["Ritual makeup, mariachi suit, pachuco hat, skull ear-rings, Aztec chest piece, snakeskin boots, 3-D glasses, low-rider glasses, bandana, black gloves, heavy-metal bracelets, and an assortment of masks and wigs".]. A segunda, se veste com um "terno preto, camiseta e 
gravata, chapeu mariachi, face estilo pré-colombiano e tatuagens nos braços, máscara de lutador, máscara "caucasiana", máscara mortuária, uniforme estereotipado "low-rider" ["Black suit, shirt \& tie, mariachi hat, pre-Columbian-style facial and arm tattoos, wrestler mask, "caucasian" mask, death mask, stereotypical "low-rider" outfit".] (p. 23).

Expressando de forma um tanto anárquica os efeitos entrecruzados de histórias que a cultura anglo e espanhola doaram aos chicanos, as personagens, ao longo da apresentação, perspectivizam um tipo de "teatro-documento", de "teatro dos fatos", uma vez que colocam em cena determinados dados concretos, fatos verdadeiros, sem dramatização aparente.

Há uma espécie de rompimento com proposições estratificadas, assim como com as convenções teatrais para dar mais dinamismo à cena do espetáculo. É como se as personagens se despissem do estado de ator e atravessassem seu aspecto físico para mostrar que a vida reage quando o que importa é começar uma trajetória de lutas em defesa de sua criatividade. As antigas representações ficaram envoltas em um tipo de fumaça temporal para ceder lugar a uma "montagem" de novas ideias e outras descrições.

Em uma cena opcional, o Asteca High-Tech e o Super-Pocho adentram o teatro de joelhos e, ao se levantarem, começam a recolher objetos da audiência, colocando-os em um cesto. Despertos de seu estado de entorpecimento e de suas certezas, os espectadores se vêm colocados dentro dos fatos aceitando uma espécie de ambiguidade que os faz tomar uma posição, ou até mesmo agir. Eles ouvem das personagens:

Há alguma coisa da qual você gostaria de se desfazer? Algo que você realmente não precisa? Dinheiro, identidade, preservativos, chaves, um poema, um cartão de crédito, sua dor, sua raiva? Tenha certeza de que você não precisa daquilo que você está se desfazendo, para encarar o fim do século vinte. (1996, p. $23)^{2}$

O exemplo serve para mostrar que a intensidade do que consideramos anormal e até mesmo impossível, de repente, se transforma em algo normal, conduzindo o espírito ao âmago de seu desassossego. 
A função da performance de Gómez-Peña é atacar os complexos coletivos da sociedade, seus mitos que não constituem, por assim dizer, invenções da mente, mas que são, na verdade, herdados de uma religião, de uma cultura, de um sangue, um clima. Quando os homens se percebem como são, caem as máscaras e o engodo vem à tona. A ação do teatro e, portanto, da Performance, tanto quanto da cena descrita acima, tem a missão de sacudir a inércia asfixiante que acomete a sociedade, revelando aos espectadores o poder oculto das formas de representar. Segundo Artaud,

\footnotetext{
só pode haver teatro a partir do momento em que realmente começa o impossível e em que a poesia que acontece em cena alimenta e aquece os símbolos realizados.

Uma verdadeira peça de teatro perturba o repouso dos sentidos, libera o inconsciente comprimido, leva a uma espécie de revolta virtual e que, aliás, só pode assumir todo seu valor se permanecer virtual, impõe às coletividades reunidas à sua volta uma atitude heróica e difícil. (1964. p. 40)
}

O interessante da imagem, nesse aspecto, então, é que, ao convidarem a plateia a participar, Super-Pocho e o Asteca High-Tech estão mostrando as possibilidades de o teatro furar abscessos coletivos para a cura de antigas feridas. De qualquer modo, quanto mais a ação do palco penetrar no que está escondido dentro de cada membro da plateia, em seus excessos, tanto mais a artificialidade das resistências enfraquecerão.

Talvez seja por esse motivo que é proposto por Gómez-Peña um voltar-se para si mesmo e perceber a desordem social, a fome, a guerra, o sangue, a epidemia da AIDS etc. Essas outras maneiras de ocorrência incidem sobre o próprio acontecimento e levam o público a perceber que, mesmo de forma virtual, essas "coisas" fazem parte da existência supostamente "real" deste ou daquele indivíduo que se encontra presente naquele recinto.

No teatro, o público participa dos acontecimentos representados, identificando-se com as personagens, além de se engajar no jogo que esta linguagem híbrida da performance institui entre o palco e o mundo. As pessoas reivindicam a liberdade de poder julgar os atores e, por essa interatividade cúmplice, conservam a liberdade de participação. 
O cenário da peça “A Fronteira do Novo Mundo" é composto por um estúdio de rádio em algum lugar do futuro, um esqueleto humano crucificado à maneira de Cristo no centro do palco, frangos mortos dependurados, uma cadeira, programas "radiorama" em diferentes línguas; tudo isso mediado por, apenas, um semi-círculo de velas separando palco e plateia .

Essa possibilidade de aproximação dos organismos vivos é o elemento que diferencia o teatro de Gómez-Peña do cinema e da TV. Em consequência dessa ressonância significativa, cada um dos gestos dos atores torna-se algo extraordinário, próximo do êxtase.

Talvez tenha sido esse o motivo de ele ter eliminado a distância entre ator e plateia. Abolindo o palco, o autor removeu qualquer tipo de fronteira existente entre a teoria do teatro e a sua arte. Por isso, nenhum daqueles que compõe sua troupe tem uma especificidade em "encarnar" uma personagem, ou de conceber e construir um cenário, ou, ainda, de organizar a entrada e saída dos intérpretes. As atividades misturadas ficam confundidas entre rotina e tradição de encenar, e a inventividade, vai, de certa forma, renovando o espetáculo.

\footnotetext{
UMA VEZ QUE A AUDIÊNCIA ESTÁ SENTADA, TODA A CASA E AS LUZES DO PALCO SE APAGAM.

Gómez-Peña anda no palco, parecendo nervoso. Olha de modo fixo para alguns membros da audiência, depois repentinamente começa a pronunciar chacras hare krishna em spanglish. Ele se volta para o sonoplasta e senta-se na cadeira. Ele fala em línguas, misturadas às palavras incorporadas.

Roberto Sifuentes está de pé, imóvel, atrás do suporte para bíblias, vestindo uma máscara de lutador e um chapeu mariachi. $(1996, \text { p. 23-24) })^{3}$
}

Na cena descrita acima, não está colocada a realidade e, muito menos, uma cópia de casos ou problemas sociais, mas as imagens que os espectadores fazem dessa realidade. Se ele deixa aberta a possibilidade de misturar a ação hare krishna com a língua spanglish, é para, supostamente, mostrar que o mito da desarmonia entre os diferentes povos deveria estar desfeito.

Diante de tal contexto sintomático, não é de se estranhar que a prática da ação seja superposta ao domínio do texto. Os atores se consagram na utilização acrobática do corpo, da 
representação com máscaras, ou do sucesso com a dança, com o canto. O problema é perceber a "existência" duplicada, alquímica entre um "isto" e a "coisa em si”, ou seja, várias identidades ocupando a cena, manifestam a imaterialidade do espírito. Assim, cada um desses meios co-habitam entre uma poesia da linguagem e uma poesia do espaço, numa forma de não pertencerem estritamente à palavra. O texto torna-se texto por meio da improvisação dos atores.

A manifestação resultante desse conflito leva a perceber a quebra da continuidade cênica. As personagens misturam várias línguas, chamam a atenção dizendo que aquilo "não é uma performance, mas um palpite de ensaio" ["This is not a performance, but a cue-to-cue rehearsal".]; que aquela "é a voz da transmissão do Asteca High-Tech na FM WXYZ, 93 megahertz acima da realidade" ["This is the voice of El Aztec High-Tech broadcasting from the heights of WXYZ-FM, 93 megahertz above rality".], e que aquilo, tampouco, é "uma arte performática, senão pura ficção científica chicana" [“This ain’t performance art but pure Chicano science fiction".] (p. 24-25).

Nessa dialética, Gómez-Peña se vale de um exercício de provocação e cinde a experiência real da experiência possível. Uma série de novas provocações surgem aqui e acolá durante o espetáculo. Por meio de uma voz de homem âncora (com eco), o High-Tech leva o pensamento do espectador a assumir profundas modificações e anuncia que "nós somos todos, finalmente, intraduzíveis filhos da chingada", ou seja, filhos da mistura de indígena e espanhol ["We are all, finally, untranslatable hijos de la chingada".] (p. 25).

Nada mais distante, portanto, do interesse erudito de se construir um sistema que dê conta da totalidade do real. Nessa passagem estão inscritas as fragmentações de um sistema social sobre o qual é necessário se pensar as faltas e as diferenças, as novas fronteiras abrindose para dispor novas polissemias identitárias. Enquanto não se incorporar que temos várias 
extravagâncias com as quais temos de lidar no mundo pós-moderno, as preocupações sobre o sistema social não surtirão efeito.

Mais do que qualquer outra construção, trata-se de entender que a vida e a obra de arte se comunicam em todos os planos em uma produção de duplo, uma da outra. Assim sendo, cabe ao ator e aos outros intérpretes, que o "sentido" seja apreendido da melhor maneira possível pelo espectador.

Esta é uma das originalidades da prática performática de Gómez-Peña. Ele não se dispõe em transmitir aquilo que dá sentido ou que contenha uma mensagem, mas parte da visão de que o único sentido deveria emergir do próprio acontecimento teatral. Uma das tendências de seu texto é fazer surgir o encontro resultante do confronto entre espectador e espetáculo. Não há distinção entre uma coisa e outra, pois esse tipo de distinção tornaria difícil e inoportuno a busca de integração das artes. A performance de Gómez-Peña se estrutura a partir de um tipo de linguagem teatral apresentada em uma espécie de mixed cênica cuja tonicidade maior pode formalizar-se em vários tipos de linguagem.

Feitas essas observações, esses signos se metamorfoseiam e ele continua indagando a plateia : "Isso é re-a-li-da-de ou performance?" [“Is this re-a-li-ty or performance?"] (p. 26) [...] "De qualquer maneira, quem somos nós?" [“Who are "we” anyway?”] (p. 27).

O extremismo das colocações parece ficar, digamos, como que suspenso, já que sua ambição consiste em fomentar os direitos do imaginário. Sua performance não se estrutura numa forma aristotélica de começo, meio e fim, linha narrativa etc., mas no seu contrário. $\mathrm{O}$ apoio é conseguido por meio de uma colagem (várias coisas acontecendo ao mesmo tempo como se fosse uma livre associação) como estrutura, e, em um discurso cênico.

Mais uma vez, sua personagem intervém: 


\section{GP/ GRAVE SOTAQUE LATINO}

(Mostrando um grande sorriso e limpando a garganta) Por favor, confiram minha pronúncia. O spanglish e o gringoñol foram proclamados línguas oficiais, línguas francas. [...] Televisa, CNN, e CBC se juntaram para criar o Reali-TV, o maior império midiático do planeta [...] O slogan deles é "TV ou não TV, esta é a questão". (1996, p. 28)

A essa altura do desenvolvimento da peça, o retorno ao texto falado provoca uma ruptura, um efeito de distanciamento enfatizados pela mudança de iluminação, pelo subir e descer do palco, pelas projeções em tela, pelos frangos mortos no palco, pelas mudanças de vozes das personagens durante toda a apresentação. Desse modo, a inserção do texto falado na continuidade do espetáculo parece não passar de uma solução instrumental. O virtuosismo bilíngue é destacado numa forma de mostrar a interação cultural, não apenas entre o inglês e o espanhol, mas com todas as outras culturas suplementares espalhadas por todos os Estados Unidos. No conjunto, a inversão apresentada é vista como um texto plural "impuro", acontecendo de sua heterogeneidade fazer gerar novas possibilidades significantes.

Unindo "isso" e "aquilo", as várias linguagens usadas aqui servem para expressar aquilo que rotineiramente não costumava acontecer. As linguagens iniciam a passagem de temas mais abstratos para outras "margens", a fim de inventarem "gestos" que evoluam no espaço.

Valendo-se desse estado, o Asteca High-Tech anuncia: “Antes de continuarmos com essa transmissão quero que todos repitam depois de mim: "Isso é arte. (pausa) Isso não é realidade. (pausa) ... Venham, vamos ouvi-la! (a audiência segue as instruções) Obrigado. Gracias. Danke shöen" ["Before we continue with this broadcast, I want everyone to repeat after me: "This is art. (pause) This is not reality. (pause) ... Come on, let's hear it" (the audience follows instructions) Thank you. Gracias. Danke shöen”.] (p. 32-33).

Diante dessa referencialização, supomos que, no fundo, os acessórios sugestivos e/ou simbólicos colocados em cena pela representação do ator, essa "mistura" de falas, fornecerão ao espetáculo, um quê de colorido pluralizado. Entre a ideia e a imagem cênica, parece haver 
um tipo de incompatibilidade legitimada teatralmente a partir do momento em que a imagem pode ser visualizada como a matriz do substrato cultural, especificamente chicano.

A estratégia usada por Gómez-Peña para “ouvir arte” revela que, de alguma maneira, sua arte é a única maneira da qual dispõe para reivindicar uma "voz", ou, para levar adiante sua luta por ideais chicanizados. Opera-se nele uma transformação do ator em mensageiro dos interesses estéticos, mercantis, comunicacionais. Sem deixar de ser esta uma con(tra)dição interessante, o Asteca afirma:

\footnotetext{
Esta nova sociedade é caracterizada por migrações maciças e relações inter-raciais bizarras. Como resultado, novas identidades híbridas estão emergindo. Todo cidadão mexicano transformou-se em chicano ou mexkimo, e todo canadense tornou-se chicanadense. $(1996, \text { p. } 33)^{5}$
}

Partindo dessas concretizações antagônicas, o universo dos grandes valores estão desfeitos. Uma outra hibridização interage com o crescimento do marginalizado urbano. Se teatro é interrogação, Gómez-Peña propõe ao espectador, com essa passagem, uma experiência dos limites. Como é deixar de ser chicano nesse processo de expulsão da antiga identidade para vir a ser um mexkimo?

Nesse ponto, ator e espectador se inserem na participação de elaborar um texto resposta. Em meio ao conflito, abunda um amplo trabalho de pesquisa e improvisação. Improvisação no sentido de agarrar o espectador pelo efeito da surpresa e levá-lo a pensar sobre o que lhe é proposto; e pesquisa, pelo fato de desorientar esse mesmo espectador, indicando outras criatividades do autor. As respostas tanto ficam no ar, como se materializam em julgamento crítico, uma vez que a tensão entre fato e ficção fica ainda mais acentuada quando o personagem exclama: “Todo mundo, agora, é um indígena da fronteira significando um nativo da grande região de fronteira" ["Everyone is now a borderígena, meaning a native of the great border region".] (p. 33). 
De agora em diante, a memória textual não se apóia mais na espontaneidade individual. Da junção de memória e contemporaneidade nascerá a realidade da vida moderna. As antigas posições sociais são transpostas e adaptadas à realidade do mundo moderno. $\mathrm{O}$ patrimônio tradicional cedeu lugar à promoção da cultura popular e a suas reivindicações. Múltiplas e profundas transformações foram efetuadas nas "fronteiras" que buscam, na arte, seu exprimir-se livremente.

Mais uma vez, essas reflexões mostram a situação de uma consciência assistindo a uma transformação participando de uma reviravolta na prática ocidental da transculturalidade.

Nota-se, portanto, que o texto passou a formular a expressiva realidade do desconhecido cultural. Repercussões mais extensas dessa comunicação cultural dimensionam o chamado work in progress, tudo para nos causar desinteresse por uma compreensão linear da obra e para que tenhamos dela uma visão explodida, fragmentada, daqueles estados legitimados em forma de expressão. Como espectador/leitores temos um percurso anacrônico a ser seguido, por meio do qual, esta história permanece legível.

De acordo com a imagem que o texto provoca, o espetáculo, na verdade, nunca está lá onde é aguardado. Ele surge sempre de outros lugares, penetra em ideologias e nos conduz por outros espaços. Assim, quando Gómez-Peña anda pelo palco daqui para lá, passando do esqueleto ao frango dependurado, e grita diante da ave, inferimos que é como se ele tivesse sendo atravessado por uma densa rede de interações despertando heterogeneidades que apelam à memória coletiva do público. Gómez-Peña pergunta se estão numa "falsa democracia" ["Falsa democracia?"], ou se os "Estados Unidos te usam ..." [“U.S.A. te usa ...”], além de fazer afirmações destacando que a "Censura não é cultura ..." [“Censura no es cultura ...”], ou que, “Não. A Censura não molda ...” [“No. Censura no escultura ...”] (p.35).

O espetáculo, então, joga o jogo da teatralidade. Não procura mostrar as ocorrências históricas diretamente, mas apela para explicações mais consistentes apoiadas na sociedade 
chicana e na América do Norte. Gómez-Peña comenta que "os norte-americanos que não aprenderam falar espanhol, sofreram uma marginalização total" ["Los norteamericanos que no aprendieron a hablar español sufrieron una marginación total”.] (p. 36).

Mais uma vez, o hibridismo anglo/espanhol destaca-se na rede da massificação fronteiriça. Transculturalizando pensamentos, imagens, patrimônio cultural e universos simbólicos, o autor promove um tipo de cultura que se expande constantemente para as margens. Ao invés de excluir os "textos", percebemos a ocorrência de uma articulação entre eles e o espetáculo no palco.

O estado das coisas, exposto na citação acima, não otimiza em nada o espectador em sua relação com o sistema. Pelo contrário, a análise que podemos fazer das novas mídias, é a de que, mesmo com as novas tecnologias e as "aldeias globais", vislumbra-se, cada vez mais, o confinamento a um período em que tudo parece saturação. É desencadeado, agora, um mecanismo de proximidade e exclusão, a partir do qual o espectador tem a sensação de estar "sobrando".

Repartindo sua participação com o público, Gómez-Peña pergunta:

Você está chateado? Por quê? Muitas ideias? A ação no palco não é suficiente? Sua vida está sem ação? Insuficiente salsa picante na sua genitália? Você está perdido no futuro imediato? Fundilhos! (1996, p. $38)^{6}$

Os espectadores são, nesse momento, mais uma vez, o próprio público do jogo. Eles são trazidos de volta às suas recordações e a eles é proporcionado um dispositivo de completo registro multicultural. Gómez-Peña usa um óculos holográfico, um chapeu pachuco e, numa voz satânica, cumprimenta: "Boa-noite América ... Bom-dia Europa. Em reação a essa transcultura oficial, um polvo e suas raízes com um milhão de tentáculos emergiu da terra, e centenas de pequenas bolsas de resistência apareceram em todo lugar" ["Good evening América ... Good morning Europe. In reaction to this official transculture, a grassroots 
octopus with a million tentacles has emerged from below, and hundreds of small pockers of resistance appear everywhere".] (p. 38).

O trânsito incessante das significações, mais o objetivo de recomeçar as interlocuções parece, então, ser a abertura de possibilidades que expressa as diversas realidades resultantes da transculturação. Os tentáculos do polvo parecem exprimir o "duplo" de uma realidade inquietante a respeito do povo chicano, e o imaginário da resistência em se deixar envolver nos tentáculos do imperialismo ocidental. Se entendermos que este imperialismo é forma de política expansionista dominando a cultura e a economia de uma nação sobre outra ocorrida durante a segunda revolução industrial, perceberemos que ele resiste em promover outras identidades. Entretanto, a autonomia para novas experimentações encontra-se à disposição para as culturas emergentes movimentarem-se estrategicamente desse "lugar" para aquele e daquele para esse.

A metáfora além-do-texto sugere e exprime o poder do teatro com suas próprias realizações. O espírito, então, serve de trampolim para uma materialidade que introduz um espaço de experimentação no qual se recombinam "chicanos das margens" e norte-americanos "centrados".

De acordo com o desenvolvimento do espetáculo, a polêmica marcando transformações culturais, sociais, e religiosas está lançada. Além de mostrar as degradações a que estão submetidos os chicanos, esse processo criativo transcende e atravessa zonas culturais fronteiriças. Gómez-Peña comenta:

Como o Protestantismo e o Catolicismo desmoronaram devido à sua inabilidade em se adaptarem à Grande Mudança, testemunhamos o renascimento de religiões pagãs. Novos deuses híbridos estão sendo adorados pelas massas confusas. (ele apanha uma cobra feita de madeira e começa a domesticála). Tezcatlipunk, o deus mexicano da fúria urbana está se tornando bastante popular em Aztlán e Tesmogtitlán. $\left(1996\right.$, p. 41) ${ }^{7}$

Continuando com a cadeia cênica que permite ao espectador procurar no espetáculo sua própria realidade, Gómez-Peña nos faz mergulhar, com essa passagem, naquele estado de 
angústia e incerteza que é próprio da poesia. Como pertencer e adorar um aglomerado de "gestos" ritualísticos se ainda não se sabe à qual divindade adorar? Como se realizar nesse novo tempo se o "cenário" oferecido encontra-se carregado de tendências psicológicas, metafísicas, filosóficas, indicando tantas outras "novas identidades” a serem seguidas?

Talvez seja para pedir ajuda nesse caminho tão bifurcado que "GP \& RS: (num ritmo sincopado)" proponham o questionamento: “A passagem do Terceiro para o Primeiro Mundo; do passado para o futuro, lembram-se?" [“GP \& RS: (in syncopated rhythm)" - The crossing from the Third to the First World; from the past to the future, remember?'] (p. 41).

A fronteira ambígua, marcando o entrelugar entre passado e presente, é referida nesta cena. À medida que Gómez-Peña resgata a tradição e a mistura com fatos de sua trajetória contemporânea, vemos surgir, de sua "fala", os conflitos interétnicos ou inter-raciais esboçando personagens pertencentes a qualquer tempo. A posição estratégica adotada por ele é a de um insider/outsider que se mostra, ao mesmo tempo, dentro e fora.

A distância entre passado e futuro, passado e presente justifica as trocas culturais entre as desigualdades das Américas. Gómez-Peña demonstra saber que é uma pessoa non-grata em seu meio artístico, mas demonstra, também, ter consciência para negociar quando e como deve se apresentar ou desaparecer ${ }^{8}$.

O fato é que esses processos migratórios escrevem o intenso fluxo existente entre as complexas relações das tradições e da inovação. Há que se reencenar o passado para se reintroduzir novas temporalidades.

Talvez seja por confrontar-se o tempo todo com essas questões que vemos Roberto Sifuentes "COM UMA VOZ COMPUTADORIZADA", exclamar o seguinte: “Arte sobre identidade é, agora, uma forma dignificada de nostalgia" ["RS/ COMPUTERIZED VOICE" "Art about identity is now a dignified form of nostalgia".] (p. 42). 
Embora muitos espaços artísticos mostrem essa consciência, acreditamos ter chegado a hora de nós, também, identificarmos nesse depoimento, o processo de recombinação mostrando a Europa e os Estados Unidos como lugares multirraciais e polissexuais, nativos e migratórios, abertos às diferenças.

Além disso, a ponte para o impossível está pronta. Não se pode mais evitar o voo aflitivo que as reivindicações do mundo pós-moderno impõem. A vasta gama de significações precisam ser ressignificadas caso se queira transpor novas noções. O crescente deslocamento dos povos, as constantes identificações a respeito de diferenças e identidades, nos fazem visualizar um emaranhado de valores a serem enfrentados.

É significativo ressaltar, portanto, a "PROPHECY IX: THE MAFIAS", em que “(GP veste bandana e óculos escuros e acende um cigarro de maconha. Durante o próximo texto, RS se transforma em um "membro de gang” e começa a "profanar" um frango. Ele cobre sua camiseta com o sangue da ave” [“GP puts on bandana and dark glasses and lights a joint. During next text, RS turns into a "gang member" and begins to "desecrate" a chicken. He covers his T-shirt with chicken blood".] (p. 44). Depois, “GP agarra um machete, anda em direção ao frango dependurado, pega-o pela cabeça, e o decapita enquanto diz: Chick ... chic ... en ... oh ... no ... Chicano ... Poder. (Ele ergue seu punho direito)” [“GP grabs a machete, walks toward the hanging chicken, grabs its head, and decapitates it while saying: Chick ... chick ... en ... oh ...no ... Chicano ... Power (he raises his right fist)] (p. 46).

Após nos defrontarmos com essa observação, o que temos visto até agora são as personagens representarem as fronteiras como os espaços móveis, coletivos, misturados, chamando a atenção para uma característica especial marcando incessantes transposições, daqui para ali, e de lá para aqui, travessias internas e externas. 
O nosso olhar para essas impressões deve ser, portanto, o de enxergar nesses depoimentos, a angústia dos atores em se sentirem exilados no próprio país. Verdadeiros artesãos de ideias, eles manifestam aos ouvintes o despertar para seus direitos.

Por outro lado, inferimos, ainda que, por meio dessa situação, cada movimento nacionalista ou individual a fim de se conseguir qualquer tipo de independência, resulta em "sacudir" o "mundo" alicerçado em nossas identidades e acatar sugestões determinadas por outras forças.

O espaço teatral, portanto, serve para que os atores levem a militância política que defendem, a se espraiar para outras localidades. É de grande relevância que, agora, por essa iniciativa, os artistas tenham conseguido dar "voz" às suas reivindicações e que tenham a ousadia de acusarem os Estados Unidos de estarem degolando os chicanos, assim como eles degolam os frangos no palco.

De uma forma ou de outra, eles não precisam mais intervir com palavras. Os gestos criam correspondências que recobrem qualquer intelecto adormecido. Por meio dessas vibrações, ficam formados e deformados os diferentes significados que o espetáculo proporciona. A estagnação do pensamento está quebrada; novos sentimentos de luta preencheram o espaço vazio do desejo, ou seja, uma espécie de linguagem multifacetada préestabeleceu o caminho entre gestos, "falas" e pensamentos.

Para iluminar ainda mais seu processo particular de provocar a plateia, a peça termina assim:

queridíssima $\mathrm{M}$,

esse seu país sem nome

apagou minha identidade original

e a devolveu com um novíssimo self híbrido

o homem fronteiriço (1955 - ?)

Eu simplesmente não sei o que pensar de seu país

até agora

estou voltando para o México

bruxa, minha língua e músculos precisam de um descanso sério

Assinado: o residente alienígena 
em busca de uma nova residência a sua! $(1996, \text { p. } 48)^{9}$

\section{NOTAS}

1- Vamos considerar texto linear, nesse caso, os textos do teatro erudito, Renascentista, imitando modelos greco-romanos, muito acadêmicos, com linguagem pomposa e temática sem originalidade (disponível em < http://liriah.teatro.vilabol.uol.com.br/história/teatro_renascentista.htm>) Acesso em; 18.fev.2009.

2- "Is there anything you would like to give away? Anything you don't really need? Money, IDs, condoms, keys, a poem, a credit card, your pain, your anger? Just be sure you don't need what you're parting with to face the end of the twentieth century". (GÓMEZ-PEÑA, 1996, p.23)

3- "ONCE THE AUDIENCE IS SEATED, ALL HOUSE AND STAGE LIGHTS GO OUT. Gómez-Peña walks on stage, looking angry. He stares intently at various audience members, then he suddenly begins doing hare krishna chants in Spanglish.He turns on the tape player and sits down in the chair. He speaks in tongues, mixed with corporate words. Roberto Sifuentes stands motionless behind the lectern, wearing a wrestler mask and a mariachi hat." (GÓMEZ-PEÑA, 1996, p. 23-24)

4- "GP / THICK LATINO ACCENT: (wearing a big smile and clearing his throat) Please check my pronunciation. Spanglish and Gringoñol have been proclaimed official languages, linguas francas [...] Televisa, CNN and CBC have joined to create Reali-TV, the largest media empire on the planet [...] Their slogans is TV or not TV, that is the question!". (GÓMEZ-PEÑA, 1996, p. 28)

5- "This new society is characterized by mass migrations and bizarre interracial relations. As a result, new hybrid identities are emerging. All Mexican citizens have turned into Chicanos or Mexkimos, and all Canadians have become Chicanadians". (GÓMEZ-PEÑA, 1996, p. 33)

6- "Are you bored? Why? Too many ideas? Not enough action onstage? Not enough action in your life? Not enough salsa picante on your genitalia? Are you lost in the immediate future? Culero!”. (GÓMEZPEÑA, 1996, p.38)

7- "As Protestantism and Catholicism collapse due to their inability to adapt to the Big Change, we witness a revival or pagan religions. New hybrid deities are being adored by the confused masses. (he grabs a wooden snake and begins to tame it) Tezcatlipunk, Mexican god of urban wrath is becoming very popular in both Aztlán and Tesmogtitlán”. (GÓMEZ-PEÑA, 1996, p. 41)

8- É imperativo salientar nessa altura do trabalho, uma declaração dada por Gómez-Peña referindo-se aos contrastes violentamente marcados pelas diferenças culturais. Ele tece as seguintes considerações: "O pano de fundo de nossa futura aventura madrileña podia se articular da seguinte maneira: 513 anos depois da conquista espanhola das Américas, os filhos bastardos de Cortés e da Malinche seguimos emigrando para o Norte. Somos a grande diáspora latino-americana para os Estados Unidos. Somos 45 milhões de pequenos órfãos do Estado-nação e constituímos uma das maiores populações flutuantes do planeta. Agora, bem: o que isso tem a ver com a Espanha?: 513 anos depois da conquista, os chicanos que de alguma forma são os netos macabros de Espanha e da América indígena, regressamos a uma $X$ paña que se pensa a si mesma "européia", "global" e "pós-moderna" (disponível em www.jornada.unam.mx/2005, de 07/06/05)

9- "dearísima M, / this nameless country of yours / deleted my original identity / and replaced it with a brand-new hybrid self: / el homo fronterizus (1955 - ?) / I just don't know what to think of your country / for the moment / I'm taking a trip back to Mexico / bruja, my tongue and muscles need some serious rest / Signed: el resident alien / in search of a new residence / la tuya"! (GÓMEZ-PEÑA, 1996, p. 48) 


\subsection{A astúcia argumentativa de Gómez-Peña e seu aspecto intrínseco de erudição}

Neste ponto do trabalho, torna-se relevante citar um diálogo entre Guilherme e Adso, personagens de $\boldsymbol{O}$ nome da Rosa, de Umberto Eco, a fim de percebermos que estamos sempre procurando uma "verdade" que nos ultrapassa e mostra a nossa incompletude como seres humanos:

\footnotetext{
"Diante de alguns fatos inexplicáveis deves tentar imaginar muitas leis gerais, em que não vês ainda a conexão com os fatos de que estás te ocupando e de repente na conexão imprevista de um resultado, um caso e uma lei, esboça-se um raciocínio que te parece mais convincente do que os outros. Experimentas aplicá-lo a todos os casos similares, usá-los para daí obter previsões, e descobres que adivinhaste. Mas até o fim não ficarás nunca sabendo quais predicados introduzir no teu raciocínio e quais deixar de fora. E assim faço eu agora. Alinho muitos elementos desconexos e imagino as hipóteses. Mas preciso imaginar muitas delas, e numerosas delas tão absurdas que me envergonharia de contá-las".

Reflete Adso então:

"Entendi naquele momento qual era o modo de raciocínio do meu mestre, e pareceu-me demasiado diferente daquele do filósofo que raciocina sobre os princípios primeiros, tanto que o seu intelecto assume quase os modos do intelecto divino. Compreendi que, quando não tem uma resposta, Guilherme se propunha muitas delas e muito diferentes entre si. Fiquei perplexo."

"Mas então", ousei perguntar, estais longe da solução ..."

"Estou pertíssimo", disse Guilherme, "mas não sei de qual".

"Então não tendes uma única resposta para vossas perguntas."

"Adso, se a tivesse ensinaria teologia em Paris"; (ou Londres, acrescento eu). [...]

Tive a impressão de que Guilherme não estava realmente interessado na verdade, que outra coisa não é senão a adequação entre a coisa e o intelecto. Ele, ao contrário, divertia-se imaginando a maior quantidade possível de possíveis. (APUD CHNAIDERMAN, 1989, p. 21-22)
}

Eis um exemplo do constante questionamento efetuado por nós, ou por qualquer sujeito, de buscar esse vir-a-ser da "verdade" que representa o vazio deixado pelo desejo, ou por outro lado, da busca daquele discurso ideológico tentando dar uma certa "normalidade" às histórias narrando sobre os limites diferenciais entre nações, povo, comunidades, raças.

Se sabemos que qualquer verdade não nos pertence e que, portanto, a busca de uma única diretriz para tal verdade não existe, é preciso inventarmos uma interpretação, ou criarmos uma "fala", nossa, para podermos assumir o descentramento que se faz presente quando assumimos o jogo do(s) "mundo(s)", ou dito de outra forma, quando jogamos o jogo da significação. 
A eficácia de um jogo ou até mesmo de uma interpretação mais detalhada não se presta a uma lógica do sentido, senão a uma ruptura. $\mathrm{O}$ jogo é jogado no entre, no espaçamento que fica entre o "isso" e a "coisa", tornando possível uma sintaxe de significação. Se não for assim, não tem como o sujeito de letras, ou o sujeito artístico satisfazer as suas pulsões que a realidade, na maioria das vezes, interdita-lhe.

Para elaborarmos estratégias legitimadoras que nos autorizem o discurso, é necessário encararmos, além das diferenças, outras tantas mudanças e símbolos inseridos numa determinada temporalidade que demanda o "signo" no qual se inscrevem as mudanças. O "inter" traz no seu bojo a diversidade inscrita e articulada do hibridismo construído pelas poderosas transformações interculturais.

Sendo assim, toda arte é o desenho do desejo e, todo o artista deveria dar livre vazão a seus desejos e fantasias para que eles não sejam coibidos pelas regras sociais ou pela gramática. Na convivência com impasses diários, torna-se necessário transgredir moldes estabelecidos. Hoje, as várias artes se misturam e escritores, pintores e atores, são homens que mudam linguagens. Todas as afirmações constroem-se no espaço contraditório da enunciação que, por si mesmo, considera a originalidade das instâncias como alguma coisa híbrida, à espera de ser lido e traduzido de outra forma.

Nessa perspectiva, os “encontros” vividos por Gómez-Peña de 1979 a 1995 e narrados em sua crônica "COLONIAL DREAMS/POST-COLONIAL NIGHTMARES - A Chronical of Performance Projects (1979-1995)", de 1995, (p. 80 a 111), mostram um contexto, todo fragmentado que resulta em campos de arte imprevisíveis para o encontro de muitas outras vozes. Sua ânsia por mudanças espreita as instabilidades ocultas em um movimento flutuante no qual sua "prática" não pode deixar de ser reconhecida como o novo lugar de enunciação.

Ele inicia o texto alegando ser 
UM CIDADÃO DE DOIS PAÍSES, UM MEMBRO DE MUITAS COMUNidades e um cabeçudo clínico geral de muitas disciplinas. Como muitos membros de minha geração, eu uso diferentes chapeus (ou máscaras) em diferentes ocasiões, e algumas vezes, mais de um ao mesmo tempo. Sou um artista ativista, um pirata da fronteira, e/ou um cidadão diplomata trans-cultural, atuando papeis temporários e mutantes do antropologista às avessas, da linguística experimental, do cronista alternativo e do reformista, nas instituições culturais dos Estados Unidos. $\left(1996\right.$, p. 80) ${ }^{1}$

Dessas afirmações resulta o fascínio brusco com o qual ele se coloca em outras vinte pequenas narrativas ao longo do texto, comentando e narrando o que lhe acontece em suas peregrinações, todas, fragmentos de uma vivência possível.

Se assumimos que o trabalho de Gómez-Peña busca articulações movimentando os desejos mais escondidos, as ações para unir o seu trabalho devem basear-se na interpretação dos sonhos e suas fragmentações.

Para interpretar um sonho cuja "escrita" secreta se dá em diferentes significados, é necessário utilizarmos um método decifrador. Traduzir um sonho é usar uma chave cuja função é abrir cada um dos componentes fragmentados para observarmos sua amplitude enquanto ponto inaugural. Acreditamos que o conteúdo dessa crônica de Gómez-Peña também leve essa mesma determinação específica de fragmentalizar-se. O que, na verdade, nos guia na interpretação de cada fragmento narrativo expresso pelo autor? Que posição devemos adotar, para ouvir cada uma das colocações perturbadoras nas vinte narrativas?

Seria inútil tentarmos trabalhar com seu texto como um todo, pois, como o sonho, é preciso haver fragmentos para que se possa associar "isto" a "aquilo", "entre" as operações. Quando a estrutura do sonho é examinada, verifica-se que o motivo do desejo que atuou em sua produção, misturou o material que lhe serviu de base para sua construção, alterando a ordem na construção de um novo conjunto. Assim como as primeiras construções de antigos palácios romanos, podemos relacionar os sonhos: pedras e colunas serviram como o material básico para construir as formas modernas. Depois, de cada "pedra" ou de cada "coluna", apresentou-se a constatação de uma lembrança ou de um fato qualquer relacionado ao fragmento. 
Dessa forma, as possibilidades do devir, das experiências transformadas em diferentes figuras, em diferentes fragmentos, retornam às reproduções desconectadas sintaticamente para que, por meio de outras reproduções, seja dado o efeito de sentido que se busca em cada proposta contemporaneizada. Isso quer dizer que a estratégia de produção no interior da ilimitada subjetivação se dá de antemão segundo o ponto de vista da vida em sua alteridade.

Seguindo afirmações de Gómez-Peña, tais como, "Em minha arte eu exploro os labirintos da identidade, as intersecções da linguagem e os precipícios da nacionalidade” [“In my art I explore the labyrinths of identity, the intersections of language, and the precipices of nationality”.] (p. 80), é possível observarmos as diferentes associações significantes efetuadas enquanto unidades de construção, pois, de acordo com Bhabha,

o "verdadeiro" é sempre marcado e embasado pela ambivalência do próprio processo de emergência pela produtividade de sentidos que constroi contra-saberes in media res, no ato mesmo do agonismo, no interior dos termos de uma negociação (em vez de uma negação) de elementos oposicionais e antagônicos. (1998, p. 48)

Assim, contra um modelo portando informações unívocas, o texto de Gómez-Peña radicaliza homogeneidades estéticas. Ao criar universos paralelos, o autor não sugere algo excêntrico com valor de uma ruptura, mas aposta na recusa da totalidade e descobre os interstícios do vazio, o espaço "entre" as artes, à espera de ser substancializado pelas mais diferentes linguagens.

Das ilusões da totalidade de decifração, vemos emergir uma aposta fragmentalizada de pensamentos vislumbrando a liberdade e o abuso que o autor pode fazer deles. Em sua tentativa de formar um diálogo debatendo posições políticas por meio da força da escrita e da performance, vemos surgir um discurso socializado que tem por objetivo definir o "para" e o “da" da ação. Ele afirma o seguinte: "Cruzamos juntos muitas fronteiras perigosas e, ao fazer isso, arriscamos nossa identidade, nossa dignidade, e algumas vezes, nossas vidas" ["We cross many dangerous borders together, and in doing so we risk our identity, our dignity, and 
sometimes, our lives".] (p. 80). Essa metáfora, como fica sugerido, toca no dialogismo que excede o mimetismo do confronto entre ideias.

Assim, desse movimento criando contato com o mundo exterior surge um GómezPeña acometido por acontecimentos violentos cuja possibilidade de salvação está em apelar para a dramaturgia da superabilidade e absorver a própria transcendência, a própria imagem. Nesse universo da colagem, do auto-circuito, onde tudo é absorvido pelo "de-vir" imagético especulado pelo mundo, há uma quantidade considerável de material inconsciente que, na maioria das vezes, torna-se fragmentos para a construção dos sonhos.

De fato, Gómez-Peña se depara com debates que o levam a se reencontrar não propriamente com o ponto de partida, mas, com pelo menos, aquele algo inaugural bastante forte. Direcionando nosso olhar para perceber que as coisas não estão mudando mas que já foram mudadas de forma até fulgurante, Gómez-Peña inicia o primeiro fragmento da crônica “The Loneliness of the Immigrant" (1979)" (p. 82), narrando a seguinte experiência: depois de alguns meses de sua chegada a Los Angeles, ele passou vinte e quatro horas em um elevador público envolvido em tecido e amarrado feito um pacote. Ele não podia se mover, ou falar. Vulnerável e anônimo, ouviu confissões que não desejava, assim como outros abusos verbais, além da discussão de dois adolescentes sobre atearem-lhe fogo ou não. Então, um cachorro urinou no corpo de Gómez-Peña e, por fim, foi atirado em uma lata de lixo industrial onde passou as duas últimas horas do dia. Para ele, essa é a metáfora do doloroso nascimento em um outro país, o nascimento de uma nova identidade. Sentindo-se excluído de maneira rigorosa, ele parece basear sua "realidade" em ajustamentos pessoais de esforços e realizações conseguidas por meio de fugas do padrão artístico que caracteriza outras obras até então.

A história narrada aqui faz vislumbrar a condição de que ele não opera um plano objetivo, planejado em termos de "sua" verdade. Ele não se aprisiona dentro de moldes de uma estrutura estreita e sequer convive em relação harmoniosa com o próprio sistema. Ao 
contrário, ele tenta fazer parte de um pensamento crítico, revoltado, quase subversivo, pecebendo que, para haver transformação, é necessário agir e pensar politicamente. Para isso, ele faz uso de sua arte como debate que questiona posições sociais e como diálogo posicionando-se como representante do povo chicano.

Tendo feito essas escolhas, ele narra por meio de outras narrativas. Se lhe é impossível canalizar as coisas para se sentir satisfeito, sua autodefesa está em mostrar o avesso da condição crítica. Ele busca, em outras falas, a instância seguinte que lhe permitiria falar, e dessa, busca uma outra, infinitamente. Gómez-Peña abre "lugares" para que o hibridismo das lutas sociais negocie os acontecimentos nesse interior de desafios, traduzidos pela contradição do cultural.

Essa diversificação parece caminhar em direção ao âmago do problema. Para GómezPeña não importa se o material do seu discurso é moral ou imoral, indecente ou maravilhoso. Ele sugere que sua primeira obrigação como artista performático é se expressar por meio de seus próprios motivos pessoais, não anulando, de forma alguma, a síntese dialética advinda de dois mecanismos dicotômicos: o apolíneo e o dionisíaco.

O primeiro apresenta a organização da razão acrescida de uma mensagem disciplinante, princípios formadores da História, enquanto o segundo é pulsão, o irracional, a desorientação emocional, percebidos nas brechas do que foi recalcado. Para ele, ao progredir com esse tipo de reflexão, interseccionam-se as convenções mais pesadas dessas duas linhas.

A espontaneidade de seus espetáculos desestrutura montagens e não segue convenções estruturadas de forma cultural. Ele se inscreve na competência dos grandes analistas contemporâneos e assume uma forma nitidamente incorporada de personagens diárias. Até mesmo o silêncio, ruídos, animais no palco, passam a ser usados como atuantes em seus espetáculos, numa forma de determinar a relação com o Outro, a interpelação para o ato crítico. Caso ele precise dar transparência a seus atos, é por meio dessas organizações que lhe 
convém representar as contradições e os conflitos enfrentados pelos chicanos. Ele não recusa uma lógica sequencializada, mas prefere afrontar a noção de comunidade chicana por meio de articulações e interesses enunciativos que levem sua mensagem, esse "algo a mais", para ilimitados confrontos sociais.

Mais uma vez, tudo isso pode ser confirmado pela seguinte passagem:

Como parte da mesma série, eu perambulei pelas ruas durante doze horas como um "sem teto", com uma expressão de desespero e solidão sentida pelo imigrante que acabou de chegar. A despeito de eu estar envolto em um zarate, e rodeado de velas e vários objetos pessoais, a maioria das pessoas me ignorou. Eu descobri que como mexicano (e como morador de rua), eu era literalmente invisível para a população branca da Califórnia. $\left(1996\right.$, p. 82) ${ }^{2}$

A partir de então, percebemos que a Gómez-Peña interessa experimentar nos limites do discurso pós-moderno a reviravolta estética desencadeada nos últimos anos. Daí, fica para nós, espectadores/leitores, mais uma vez, a pergunta: “quem” narra no texto pós-moderno? Segundo Santiago, no período pós-moderno,

a figura do narrador passa a ser basicamente a de quem se interessa pelo outro (e não por si) e se afirma pelo olhar que lança ao seu redor, acompanhando seres, fatos, e incidentes. [...] o narrador se subtrai da ação narrada [...] e, ao fazê-lo, cria um espaço para a ficção dramatizar a experiência de alguém que é observado e muitas vezes desprovido de palavra. (p. 49 a 51)

Embora essa "estranheza" seja condição de deslocamento entre o "aqui" e o "lá", conviria tomarmos essas considerações para prosseguirmos com nosso trabalho, pois no segundo fragmento da crônica, "Spanglish Poetry Reading in a Public Bathroom (Cal Arts, 1979) (p. 83), as diversas formas nascidas daí fazem em um movimento de vaivém, nossos "olhares", “espacializados”, ficarem confundidos com essa mostra inquietante.

Para o desassossego de todos, Gómez-Peña narra que essa peça foi pensada como:

uma outra tentativa de trazer a performance e a linguagem para contextos não usuais e romper com o sentido cotidiano. Durante vinte e quatro horas sentei-me num vaso sanitário e li, em voz alta, uma poesia épica descrevendo minha jornada para os Estados Unidos. Quem quer que entrasse no banheiro por qualquer razão - experienciou o texto. 
Por meio desse e outros experimentos desse tipo, interessei-me por atuar para "audiências involuntárias". (1996, p. 83)

O "involuntário", nessa especificidade, pode ser entendido como a característica de Gómez-Peña em dispensar o auxílio de qualquer maquinaria para se ver integrado, por completo, na relação entre ator e espetáculo, nesse caso, o ouvinte. Em função desse modo de se relacionar, ele representa penetrando em profundidade no meio do público.

Nesse sentido, o seu objetivo é o de romper com a dependência da imagem que se tinha dos objetos do mundo para "representá-los" de maneira ("real”) ou imaginária como se fossem figuras indefinidas, irreconhecíveis dentro de um espaço cujo itinerário constante implode sistemas da codificação artística.

É importante enfatizar, portanto, que o legado construído por Gómez-Peña no fragmento citado acima, é uma espécie de referencialidade, uma forma de se trabalhar as estruturas essenciais que sustentam o discurso humano, ou seja, o direcionamento para se visualizar certos sistemas filosóficos, semiológicos, histórico/culturais e sociais.

Reconhecidamente, suas técnicas nos levam a visualizar os instrumentos sofisticados para estruturar seus "absurdos" que, em outras épocas como a da existência do "Hospital Geral" criado por Luis XIV em 1656, talvez o levasse a ser encerrado como aquele desarrazoado, desatinado, estrangeiro, necessitando ser "recuperado" em um espaço de clausura, dentro do hospício.

A partir dessas concepções, deparamo-nos com as estratégias desse artista/autor seguindo uma forma de se exprimir até mesmo em relação a fragmentos elipsados. As elipses, além de circularem implícitas na textualidade, deixam marcas que possivelmente não ficarão indiferentes para "quem fala" no texto. Se a sua função é a de representar uma figura ideológica, nada mais seguro do que afirmar que sua polissemia funciona como o novo acordo entre o "antes" e o "depois", determinado pela voz daquele que fala, seja essa voz uma estrutura linguística, mental, social ou qualquer outra. O que importa é que a estrutura 
significativa da elipse deve sua existência a uma outra significação, presente e elaborada por um sujeito coletivo.

Nesse sentido, no fragmento seguinte "Mexiphobia: Postrevolutionary Situations" (1980) (p. 83-84), Gómez-Peña incrementa o texto com universos paralelos evidenciando que uma integração entre os povos (o coletivo) está difícil de acontecer. $\mathrm{O}$ autor descreve que, de acordo com suas buscas efetuadas para descobrir vestígios da história chicana, ele se depara com a singularidade de se sentir rejeitado, distanciado do (ex)centro. Para ele, as referências sobre a alteridade cultural de um povo, dependem mais da imposição de ideias do estrangeiro, do que das estruturas culturais internas da própria nação. Assim sendo, ele comenta: "A maioria dos americanos percebe os mexicanos por meio das lentes distorcidas de Hollywood e das culturas popular e de massa estereotipadas: para eles, nós somos criaturas míticas que habitam a terra do medo e do desejo" ["Most Americans percieve Mexicans through the distorted lens of Hollywood, and the stereotypes of pop and mass culture. To them, we are mythical creatures who inhabit a landscape of fear and desire”.] (p. 83).

Segundo o ponto de vista de Gómez-Peña, seu campo de atuação deveria ser tomado como um significado transcendente e ampliador do jogo da significação. No entanto, para a polícia de Los Angeles ele "parece 'suspeito' [...] por ser mexicano" - ["for looking “suspicious” [...] for being Mexican”] (p. 83).

Como, então, assumir esse paradoxo e resistir aos eventuais contrasensos? Como desprender-se de uma marca que sempre foi sua, a dos confrontos, caso quisesse fazer parte do mesmo conjunto heróico dos "grandes" narradores?

Gómez-Peña desaparece do espaço da escrita para que, em seu lugar, apareça o sujeito que se envolve na ordem do "apagamento". Ele se insere na desestrutura operacional enquanto pensamento e, então, demonstra questionamentos difíceis de serem respondidos, tais como: Qual o papel do artista? Seria o de se transportar em um completo anonimato ou o de 
demonstrar suas características empíricas de autor? Ou ainda: o que é uma obra de arte? Poderia ela compor notas rascunhadas em um caderno, projetos narrativos, rasuras, um bilhete? Não basta, evidentemente, apenas pensar as questões. É preciso que localizemos o espaço vago deixado pelo desaparecimento do autor para que no lugar dessas lacunas livres funcione a "palavra" fundadora, ontológica do discurso.

Sem dúvida nenhuma, toda essa complexidade fica demonstrada no seguinte comentário de Gómez-Peña: “Certa vez eu comi em um restaurante extravagante vestido como um 'típico terrorista latino'. O lugar se esvaziou depois de cinco minutos de minha chegada" ["Once, I ate at a fancy restaurant dressed as a "typical Latino terrorist". The place emptied out within five minutes of my arrival".] (p. 84).

O fato termina em escândalo e o fluxo de sua criatividade se associa ao modo de encarar a arte como a procura vital que produz fortes emoções e pensamentos desarticulados do sossego. A função da sua arte, no espaço e no tempo, desposa o privado e o público e se caracteriza da seguinte forma: algo acontece naquele instante, naquele lugar e avança mais depressa em direção aos contrários.

Para realizar tudo isso, o autor se apropria de quase todas as linguagens pré-existentes fazendo uso de narrativa textual, do teatro, da performance, da dança, da arquitetura, do design urbano e, nessa massa híbrida de linguagens, marca o nascimento de algo inédito que, sem perder a conecção com o passado histórico da Raza, emerge com uma nova roupagem, uma nova identidade própria: uma consciência enunciativa capaz de se definir como justificativa para levar adiante sua arte de experimentação.

Seguindo esse processo, ele se transforma em um sujeito multiplicado, descentrado, interpelado continuamente por outras identidades, instáveis, que o fazem, em nível cultural, enfrentar desafios constantes. 
Sendo assim, quem pronuncia o vocábulo "identidade", defronta-se com "diferença". E, se assim é, essa característica, homóloga à figura do sujeito em Gómez-Peña, nos faz pensá-lo como aquele sujeito transformador da cultura, que nega o "verdadeiro", "prometendo" alterar o jeito de pensar da sociedade.

Nesses termos, o sujeito identificado no quarto fragmento da crônica "Protomulticultural experiments: Poyesis Genética” (1981-1984) (p. 85-86), emerge como aquele "ser" obcecado pelo que pode fazer para enfrentar e talvez, até, mudar o horizonte das possibilidades culturais. Ele narra o seguinte: "Nosso objetivo era (eu menciono em uma brochura antiga): desenvolver linguagens sincréticas capazes de articular nossa instável condição como forasteiros e estéticos excêntricos. Começamos por explorar a noção de uma crescente cultura de Terceiro Mundo dentro do retraído Primeiro Mundo" ["Our objective was (I quote from an early brochure): to develop syncretic languages capable of articulating our unstable condition as cultural outsiders and aesthetic freaks. We began to explore the notion of a growing Third World culture within the shrinking First World”.] (p. 85).

De certa maneira, quando nos deparamos com essas afirmações, percebemos um vínculo umbilical sendo desfeito entre sujeito e objeto, pois no momento em que o autor estabelece uma desconexão com o Primeiro Mundo, vemos ser instituído um sujeito mediado por outras ideias, interpelado por outras formas de estruturação assim como por uma instância instável e múltipla, prestando-se ao enfrentamento de novas operações, sejam elas históricas, sociais ou culturais.

Partindo desse ponto, fica claro que por meio de todas essas linguagens modificadas, Gómez-Peña se constitui como sujeito pós-moderno e adquire significados culturais, sem se esquecer de combinar presente e passado histórico, racionalidade/irracionalidade, liberdade e determinismo. Toda essa variedade não poderia resultar, portanto, noutra coisa senão em uma discursividade sempre em andamento. 
Com efeito, ele rompe com as origens e não se priva de dimensionar o contraditório universo que tem diante de si quando quer se ver independente para contemplar a velocidade dos sinais urbanos, do mundo em movimento, da arte em movimento. Sua "palavra proibida", considerada como "loucura" na relação "eu/outro" tem, agora, a possibilidade de ser manifestada como experiência da própria experimentação. Ele narra o seguinte:

\footnotetext{
Eu rapidamente aprendi que ser um "artista mexicano" nos Estados Unidos significava - gostasse ou não - ser um membro da cultura de resistência; e que a arte que eu estava fazendo era percebida pelo mundo como "menor", "periférica", e intelectualmente não sofisticada. Também percebi que como mexicano em processo de chicanização, eu podia ter mais em comum com outras pessoas de cor morando nos Estados Unidos do que com outros mexicanos que nunca deixaram o México. (1996, p. $85)^{4}$
}

À maneira de muitas “vozes”, Gómez-Peña perpassa com essa citação, a forma como cria as várias interfaces que, de seus muitos níveis de complexidade, atingem o espectador em todas suas habilidades afetivas, lúdicas, intelectuais etc.

Desde então, a "cena" não é mais necessariamente do ator, mas sim, de um componente a mais do espetáculo que pode ser desenvolvida por todos. Diante da vontade de saber do espectador, ele relaciona uma coexistência entre "meu espaço" e o "espaço do Outro", fazendo-nos vislumbrar os vários posicionamentos da violência racial sofrida pelo chicano. Mais do que estranhar esse posicionamento, deveríamos pensar nos assassinatos, nos estupros e nas "degolas" cometidos contra os chicanos/as na fronteira México/Estados Unidos.

Devido a esse seu jeito de agir, em “The Velvet Hall of Fame (ongoing)", ele declara amar "a ideia da cultura popular e turística invadindo os templos da grande arte" ["I love the idea of pop and tourist culture invading the sacred tamples of high art”.] (p. 86-87).

Sem dúvida, com essa afirmação, sua arte não se compõe apenas de "materialidades" disponíveis à mão, mas também, de uma infraestrutura que o leva a inventar e distribuir sua arte entre as muitas fronteiras. $\mathrm{O}$ seu ser da linguagem, tanto quanto o da contemporaneidade, 
é o da passagem para fora, do distanciamento, assim como o da diferenciação e da fragmentação fazendo aparecer, segundo Foucault, "um espaço vazio, o espaço de uma linguagem neutra, anônima" (2001, p. 114).

Dessa forma, Gómez-Peña proclama junto com um grupo de artistas chicanos, mexicanos, e americanos, uma forma de arte binacional coletiva e elege a região de fronteira como "um laboratório para experimentação social e estética" ["We proclaimed the border region a laboratory for social and aesthetic experimentation".] (p. 88).

Mais uma vez, o diversificado componente sígnico de sua arte fica evidenciado nessa mescla interconectada de sistemas. A justaposição de imagens instauram momentos que progressivamente vão representando o mundo, real ou imaginário, como constituidor de figuras distintas. Ao declarar "se a patrulha da fronteira chegava, nós cruzávamos para o lado mexicano e vice-versa", ele demonstra o retorno ao próprio vazio, marcando a ausência a ser substancializada pelo próprio texto na busca constante da origem das identidades chicanas ["If the U.S. border patrol came too close, we crossed to the Mexican side, and vice versa".] (p, $88)$.

Sem pretender exaurir outros conceitos, poderíamos identificar nessa sua afirmação, uma metáfora para entendermos a cultura como sendo formada por uma infinidade de misturas. A mistura cultural permite reencenarmos o passado de temporalidades e espacialidades possibilitando leituras conflituosas de identidades, mas que formam, por isso mesmo, desafios e expectativas para se visualizar o multiculturalismo. Segundo Bhabha, "É na emergência dos interstícios - a sobreposição e o deslocamento de domínios da diferença que as experiências intersubjetivas e coletivas de nação [nationness], o interesse comunitário ou o valor cultural são negociados" (1998, p. 20).

Ao levarmos em conta esse pensamento, não nos surpreende, portanto, que a arte de Gómez-Peña esteja inserida nas dicotomias tempo/espaço real, tempo/espaço ficcional, assim 
como personagem/indivíduo, personagem/ator, diretor/autor. Os recursos usados pela linguagem cênica se misturam à linguagem da performance, que, mais uma vez, incorporam o uso de diversos recursos visando a busca de um discurso para expressar tradições, expectativas futuras, lutas e confrontos dentro da própria cultura.

Aplicadas aos chicanos, essas determinações têm resultado no apelo do cidadão para que haja uma mudança para melhor nas suas condições sociais, suas vidas a fim de serem vistos como "pessoas de bem" e não, como aqueles "indocumentados" representando, apenas, problemas para a sociedade americana. Segundo Torres, é comum o norte-americano caracterizar "os mexicano-americanos essencialmente como uma massa sem instrução, ignorando a existência de uma tradição literária em espanhol no território conquistado [...]", além de indivíduo "preguiçoso, ignorante, criminoso potencial, e, portanto, nada digno de confiança" (2001, p. 21-22).

Ao longo da história, portanto, essas distinções relacionadas ao povo chicano, só fizeram derivar um crescente sentimento de reação moral e social para se autopermitir inserir na cultura americana. Reservando-se o direito de conservar tradições, o chicano vai em busca do "sonho americano", e tenta se distinguir ali, como a "nova consciência mestiça" (ANZALDÚA, 1999). O desejo para se impactar intelectualmente com o Outro é duplicado pela linguagem que, de uma forma ou de outra, toma posições de defesa para articular os interesses do grupo, pois a estratégia discursiva reage para demarcar significações culturais e políticas, em uma dimensão que abarca o interesse chicano.

Este é, de certa forma, o conjunto dos vários elementos caracterizadores de todo o grupo que compreende desde religião e costumes sociais, direitos culturais e expressões identitárias, até as práticas sociais, organizações corporativizadas, regulamentador da vida socializada da cultura chicana. 
De fato, parece ser essa a concordância expressa por Gómez-Peña quando ele manifesta suas "peregrinações performáticas" empreendidas nas fronteiras dos Estados Unidos e Canadá, Ontário e Estado de New York, Tijuana e Quedas do Niágara, até que em 1988, dessas polêmicas encenações, nasce o "Bruxo da Fronteira". Embora tenha surgido como a polêmica figura que ataca o imperialismo neocolonial, o "Bruxo da Fronteira" caracteriza o profundo binarismo "teoria versus política" existente em qualquer discurso de produção de sentido.

Dessa forma, a imagem dessa personagem não é apenas a imagem como acessório mimeticamente representando uma nova identidade chicana, mas a realidade aparente destacando as ausências provenientes de todo o campo semântico caracterizador do problema de identificação enfrentado pelos chicanos. O que emerge das entranhas textuais é o espaço enfatizando a busca pela identidade que não cansa de ser fronteiriça.

Adotando um posicionamento implacável de inventar o contramito da pureza, o Bruxo pode ser visto como a imagem especular, o lugar enigmático de onde fala o ativista político. A partir desse ato de escrever a própria mistura cultural, a personagem pronuncia: "Então, nós andamos aproximadamente dezoito quilômetros de San Ysidro ao Parque Balboa em San Diego. Naquela noite, Hugo e eu encenamos uma performance na qual nós 'trocamos nossas identidades"” ["Then, we walked approximately eighteen kilometers from San Ysidro to San Diego’s Balboa Park. That night, Hugo and I did a performance in which we "exchanged our identity".] (p. 92).

Nessa tarefa de conviver com tendências atuais, Gómez-Peña rejeita a dualidade entre matéria e espírito e junta as duas partes numa contratendência que provoca a visualização de novas ideias, crenças e valores, resultantes das misturas entre passado e presente culturais, entre política e teoria, hegemonia e diferença. Ao invés de ficar na dependência de métodos funcionais, ele analisa os diferentes níveis e estratos da cultura chicana e norte-americana, e 
os apresenta em forma de arte. Sua visão caracteriza sua "escola" e, nessa diversidade, ele chama a atenção tentando dizer que cultura não é apenas o resultado de ações humanas, mas tudo aquilo que conduz essas ações. De acordo com Bhabha, "a razão pela qual um texto ou sistema de significados culturais não pode ser autosuficiente é que o ato de enunciação cultural - o lugar do enunciado - é atravessado pela différance da escrita” (1998, p. 65).

Isso exige que repensemos as zonas de instabilidades nas quais Gómez-Peña se insere para pensar, de maneira simbólica, a função social do grupo para a produção de sentido, pois este nunca é apenas mimético e transparente.

Por necessitar de se locomover por meio de todos esses interstícios, a partir de 1991 Gómez-Peña dá início a mais uma de suas experimentações. Ele não se contenta em apenas levar sua performance daqui para ali. Com a artista e escritora Coco Fusco, ele introduz a estratégia performática de "segregar" a audiência e levá-la a participar, todos juntos, das ações de sua criação.

A postura do autor em ampliar e dividir suas inquietações com o público é, como temos verificado, óbvia e instigante. A importância com que ele destaca comportamentos das culturas das quais faz parte, a mexicana e a americana, verifica-se como a ferramenta que o leva a aprender, compartilhar e avaliar posicionamentos referentes à evolução histórica das duas sociedades.

Cada um dos seus pontos de vista parece demonstrar que, para ele, não importa a padronização que envolve uma cultura e seus movimentos de repetição comportamentais, mas sim, aqueles elementos que se modificam tanto na forma quanto na função. Provavelmente por isso ele quebre certos valores e integre outros em sua arte, de forma a inovar e variar aquela estabilidade cultural que, mais cedo ou mais tarde, acaba mudando.

Gómez-Peña então exemplifica esses comportamentos desestabilizantes quando em 1992, com a amiga Coco Fusco, mais uma vez, leva sua arte a consequências imprevisíveis. 
Incluindo dioramas ${ }^{5}$ em suas excursões, deixam-se passar por "autênticos primitivos" [“Authentic primitives"] que, de dentro de gaiolas, podem ser observados e explorados pelo público que os visita. Eles são “os ameríndios não descobertos” provenientes da "ilha (ficcional) Guatinaui (spanglização de "what now") que, tanto podiam "escrever em um laptop", quanto "por uma modesta quantia, representar 'autênticas' danças Guatinaui" ["undiscovered Amerindians" - "from the (fictional) island of Guatinaui (Spanglishization of "what now" - "we would write on a lap-top computer" - "for a modest amount, we would perform "authentic" Guatinaui dances".]. Além dessas extravagâncias, "por cinco dólares, os visitantes poderiam ver as genitálias do espécimen macho" [“for \$5.00, the audience could see the genitals of the male specimen".] (p. 97).

Frente a essa singularidade, é como se a exclusividade do humano estivesse dissolvida, pois, uma vez confrontado com criaturas "tão raras", o questionamento sobre os seus limites, sobre suas duvidosas fronteiras estão desfeitas. O espaço vazio deixado pelo espanto assume a posição de caos, barbárie, violência, numa repetição ambivalente de mostrar que a crise autoral é bem mais profunda. O reconhecimento da autoridade requeria, naquele momento, uma legitimação para além do conteúdo conflitante, ou seja, as marcas deixadas por GómezPeña comentando sobre os "espécimes" chicanos, necessitavam outras manobras estratégicas para "tocar" os visitantes, e mudar a sociedade. Esta se encontrava estagnada, sem saber o que fazer, esperando que soluções viessem prontas.

Vale enfatizar, nesse ponto, que as crenças contemporâneas estão vinculadas às experiências mediadas por artefatos tecnológicos, sejam eles reais ou simulados, próximos ou distantes, presentes ou ausentes, e, por isso, o que importa é a experimentação, o poder de tornar-se Outro, sentir o nascimento de um outro corpo. Isto é, o importante seria ultrapassar as fronteiras da especulação colonial ainda não confrontadas, para ousar apreender a si 
próprio como sujeito fusionado por duas culturas, a de origem anglo-saxã e a espanhola. De acordo com Santaella,

\footnotetext{
podemos cada vez mais protetizar o corpo, a ponto de haver a pretensão de duplicar os corpos, isto é, de ter vários corpos simultaneamente. $\mathrm{O}$ devastador desmoronamento que isso provoca nas confortantes noções de identidade nunca poderá ser suficientemente enfatizado. (2004, p. 31)
}

Sob esse ponto de vista, o princípio de estabilidade, seja cultural ou outro qualquer, está atrelado ao cruzar e recruzar fronteiras; em fundirem-se e dividirem-se em adições de um outro resultado, uma vez que as mudanças estão em incessante interação entre tradição e contemporaneidade, partes de um mesmo continuum.

Por meio dessa coextensividade simbólico/cultural, a arte de Gómez-Peña continua vigorosa, misturando o antigo homogêneo às oposições da arbitrariedade. Dividindo um espaço diorama com seu amigo James Luna, ele dependura uma placa no pescoço na qual se lê: "Era usual haver um mexicano dentro desse corpo" ["There used to be a Mexican inside this body".] (p. 100).

O dialogismo que se estabelece aqui mostra os espectros de uma sociedade quanto a seus aspectos culturais, políticos ou econômicos. Por que o "lugar" ocupado por um indivíduo “costumava ser" o de um mexicano, ao invés de "ser" um mexicano? Por que deve haver essa "seleção natural" entre os homens em detrimento de alguma coisa maior que apoie esse mesmo homem? É importante destacar dessa passagem, o desdobramento entre o ator e a personagem, pois o ator, ao entrar no espaço-tempo cênico, ele já está “significando".

O notável é perceber essa distinção como o suporte para se entender a diferença. A questão de se "considerar" ou não o outro tensiona as impressões deixadas pela encenação pois, diante de todas as transformações pelas quais a cultura chicana vem passando, a desigualdade continua sendo a mais marcante, sempre presente. E mais, a diversidade das diferenças inscritas como fenômenos culturais e suas complexidades, nos obrigam a 
concordar com Canclini, quando afirma que hoje as culturas são fluidas, fronteiriças, heterogêneas, desterritorializadas. Segundo o autor,

\footnotetext{
Ser artista ou escritor, produzir obras significativas no meio dessa reorganização da sociedade global e dos mercados simbólicos, comunicar-se com públicos amplos, tornou-se muito mais complicado. [...] O popular e o culto, mediados por uma organização industrial, mercantil e espetacular dos processos simbólicos, requerem novas estratégias. (1997, p. 96)
}

Poderíamos dizer, portanto, que a ressignificação comunicativa em Gómez-Peña está em defender interstícios e deslizamentos de uma heterogeneidade cultural pluritemporal e espacial. Ele dinamiza todas essas impressionantes transformações quando, ao se juntar com seu amigo Roberto Sifuentes em 1994, afirma o seguinte: "Ele é um chicano em processo de mexicanizaçao, e eu sou um mexicano em processo de chicanização" ["He is a Chicano in the process of Mexicanization and I am a Mexican in the process of Chicanization”.] (p. 102).

A afirmativa produz diferentes níveis de interpretação representando diversificados conflitos de classes. As dificuldades que encontramos para entender com presteza o perfil chicano e o mexicano, são acompanhados de algumas ilusões para se dizer, com autonomia, o que é ser chicano, ou o que é ser mexicano. Parece haver nesse jeito de falar, ainda, um tipo de questionamento que se expressa como continuidade estratégica: assumindo-se chicano ou mexicano, Gómez-Peña não quer assumir a posição de minoria, sequer negar sua diversidade. Ele está, podemos dizer, anunciando o importante desafio de marcar sua identidade e sua diferença. Sua "presença", aqui, resiste a qualquer discriminação. Como indivíduo discriminado, representa os nativos chicanos que constroem o sistema cultural das margens e sua própria aporia.

Além disso, devemos deduzir daí o cruzamento sócio-cultural em que tradicional e moderno se mesclam, tanto quanto a volatilidade da cultura chicana e da mexicana, assim como a dinâmica própria de cada uma acrescida por seus impactos sociais. 
São necessários muitos argumentos para se enfrentar as lutas em defesa dessas fronteiras. Anzaldúa, por exemplo, se orgulha em afirmar que os chicanos são a "nova consciência mestiça”, embora existam certas camadas da sociedade mexicana que não aceitam com bons olhos a visita de um chicano em "sua casa".

Em meio à profusão desses aspectos, salta a nossos olhos a releitura feita por GómezPeña da crucificação de Cristo, num gesto, talvez, de rearticular o "herói” salvador da humanidade.

Ele e seu amigo Roberto colocam-se crucificados em uma praia, performativizando a externação de uma ideologia. Ao unir a total liberdade de manipulação enquanto ator à sua força de estabelecer uma expressão estético/ideológica, essa atuação cênica parece compor-se de verdadeiras preocupações em fazer desaparecer o "objeto representado" para em seu lugar surgir o "objeto real", uma espécie de fusão entre vida e arte, ou um tipo de presença autoral para falar em nome dos chicanos. Se os "irmãos" não conseguem ter uma "voz" marcando a coexistência dos menos favorecidos, ele, Gómez-Peña não se recusa em se oferecer como sujeito da diferença a edificar a "raça chicana".

O palco, agora, é qualquer "lugar", e o "tempo" é o de parodiar a opressão sofrida pela cultura chicana afirmando as dificuldades que o "entrelugar" oferece para serem vividas. A existência toca o lado de cá e o lado de lá, em um espaço/tempo dinamizado pela globalização desenfreada, imposta pela pós-modernidade. Já não se reivindica apenas o "local” do conhecimento, mas sim, o "global" interiorizado a partir do exterior.

Antigas certezas como "nação", "cultura", "centro", "periferia" e tantas outras, se entrecruzam na cena para comporem histórias nacionalizadas, para contar outras diásporas do planeta. Novos espaços são construídos a partir dessa encenação e novas geografias sociais e de resistência se encaixam aí para mostrar a enorme diversidade de vozes que o quadro apresenta. O hibridismo, então, apresenta-se como o formador da produtividade do poder 
discursivo e nada mais perturbador do que essa vigilância para se descortinar as presenças da autoridade histórico-cultural.

Todas as leituras que se pode fazer daí levam a releituras da multiplicidade de discursos relacionados com o poder local (eu), versus histórias globais (o outro). Se essa foi uma estratégia do autor para chamar a atenção sobre o "povo relegado" às margens, ele conseguiu, pois ao afirmar que as fotos sobre a crucificação apareceram "entre outras publicações, no Der Speigel (Alemanha), Cambio 16 (Espanha), Reforma e La Jornada (México) e vários jornais dos Estados Unidos", ele mostra como o discurso do colonizado pode se dar em perturbações que devem ser enfrentadas pelo outro hegemônico ["The image appeared in, among other publications, Der Speigel (Germany), Cambio 16 (Spain), Reforma and La Jornada (Mexico)”.] (p. 103).

Em conformidade com esses entrelugares, é como se Gómez-Peña tivesse a urgência de desnudar a pele, viajar pelos êxtases do cérebro, descortinar o além para visualizar um mundo futuro a ser explorado pelo potencial do corpo pós-orgânico. O que se pode atravessar, ainda, depois de todas essas ilimitadas possibilidades físicas? Que organismo consegue ligar tantos ritmos além do biológico e do tecnicamente equilibrado?

É por trafegar em todos esses espaços que Gómez-Peña continua com suas apresentações, sempre, segundo ele, "em movimento". Assim, nessa coevolução acelerada, vamos encontrá-lo junto com o amigo Roberto e James Luna em apresentações da "esfera pessoal à pública, e do espaço ritual ao ciberespaço" ["processes that go from the realm of the personal to the public, and from ritual space to cyberspace".] (p. 105), exibindo-se como "exóticos espécimes culturais" ["exotic cultural specimens"] e "artistas performáticos em serviço" ["performance artists at work".] (p. 106)

Novamente o autor ultrapassa seu fluxo criativo, exagera, transforma. Atribui-se justapor imagens que na realidade cotidiana nunca apareceriam juntas para, de forma segura, 
cravar em nós o espanto máximo. Dessa vez, de forma lúdica, convidam o público a interagir com eles pela Internet. Eles têm uma página na Web e pedem para serem "visitados", denominado-se a si próprios como "etno-ciborgs, criados pela imaginação dos usuários da Net" ["we were ethno-cyborgs, created by the imagination of the Net users".] (p. 106).

O espaço expandido para várias dimensões sugere a metáfora de um espaço que deveria ser preenchido pelas polimorfas "vozes" vindas da globalidade pós-moderna. A experiência de se poder "falar" de quem quer que seja, atravessa "organismos" e pode se conectar a qualquer outro remoto desconhecido.

A "naturalidade" artificial do efeito sugere um novo modelo de sensibilidade. Nada mais temático do que a rede Net. Atualmente, tudo se faz por meio das "redes", mesmo quando não se quer transmitir nenhum tema. Outrossim, somos observados desde um simples "Sorria, você está sendo filmado", até um olhar mais penetrante dissecando nossa internalidade.

As desordens identificatórias constituem, por isso mesmo, as fragmentadas entrelinhas do ainda inexplorado. Estamos oficialmente "ligados" ao ambiente da rede. Nada mais significativo para nos conectarmos aos mistérios humanos e, por isso mesmo, estarmos sempre em continuidade com o novo a ser descoberto, com o novo a ser explorado, de maneira cotidiana, sendo, sempre, (re)construído.

\section{NOTAS}

1- "I AM A CITIZEN OF TWO COUNTRIES, A MEMBER OF MULTIPLE COMMUNIties, and a stubborn practitioner of many disciplines. Like many members of my generation, I wear different hats (or masks) at different times, and sometimes more than one at once. I am variously an activist artist, a border pirate, and/or cross-cultural citizen diplomat, performing the temporary and ever-changing roles of reversed anthropologist, experimental linguist, alternative chronicler, and reformist within the Unites States'cultural institutions". (GÓMEZ-PEÑA, 1996, p. 80)

2- "As part of the same series, I laid for twelve hours on the streets as a "homeless person", as an expression of the despair and loneliness felt by a newly arrived immigrant. Despite the fact that I was wrapped in a zarape and surrounded by candles and various personal belongings, most people ignored 
me. I discovered that as a Mexican (and as a homeless person), I was literally invisible to California's Anglo population”. (GÓMEZ-PEÑA, 1996, p. 82)

3- "This piece was another attempt to bring performance and language into unusual contexts, and to disrupt people's sense of the quotidian. For twnty-four hours I sat on a toilet and read aloud epic poetry describing my journey to the United states. Whoever happened to come into the bathroom - for whatever reason - experienced the piece. Through this and other experiments of its kind, I became interested in the notion of performing for "involuntary audiences". (GÓMEZ-PEÑA, 1996, p. 83)

4- "I rapidly learned that to be a "Mexican artist" inthe United States meant - wheter I liked it or not being a member of a culture of resistence; and that the art I was making was perceived by the art world as "minor", "peripherical", and intellectually unsophisticated. I also realized that as a mexican in the process of Chicanization I might have more in common with other people of color living in the United States than with other Mexicans who never left Mexico". (GÓMEZ-PEÑA, 1996, p. 85)

5- "Diorama é um modo de apresentação artística, de maneira muito realista, de cenas da vida real para exposição com finalidades de instrução ou entretenimento. O termo foi inventado por Ouis Daguerre, em 1822, para um tipo de display rotativo. Apresentada na Inglaterra, Paris, Escócia e Irlanda de 1822 a 1880, era um entretenimento popular derivado de "Panorama" (pintura panorâmica), cuja experiência teatral era observada por platéias em teatros especializados". (disponível em <http://hemi.nyu.edu>) Acesso em: 2.dez.2008. 


\subsection{O legado de Gómez-Peña para a cibercultura: como os leitores podem acompanhar suas propostas}

Se a toda hora nos chamam a atenção para leituras distintas, de maneira não sequencial fragmentamos informações das mais diversas naturezas e se, a cada momento experimentamos e interagimos com potencialidades dialógicas, nada mais multilinear e labiríntico do que as "imagens" que são identificadas por nós no texto performático de Gómez-Peña “NAFTAZTEC: PIRATE CYBER-TV FOR A.D. 2000” (1994), em interatividade com uma transmissão televisiva e radiofônica (p. 111 a 125).

Desde o momento que lançamos um rápido olhar para as páginas onde está escrito o texto, percebemos que a ordenação sintático-textual que deveria estar previamente prescrita como costuma acontecer, apresenta-se feito um tipo desordenado de fragmentos tentando estabelecer conexões eletrônicas com projeções em tela, voz em off de um estúdio com uma transmissão ao vivo, e chamadas telefônicas interagindo com os atores no palco, El Naftaztec e o Ciber-Vato. No decorrer da apresentação, estes interagem com outras "vozes", respondendo perguntas ou fazendo comentários sobre temas que lhes foram solicitados. Além disso, outros dispositivos ampliam essas relações: projetadas no telão, aparecem certas referências expressando informações sobre a ancestralidade asteca.

A dinâmica evolui por meio de uma enxurrada de "visões" motivando em nós, a realização de um processo inteiramente novo de "navegação" entre as cenas para que se torne possível de entendimento. "Ver" por meio dessas complexidades significa alterar o uso de nossos sentidos substituindo-os por procedimentos que produzem diferentes construções sintetizando o ambiente no palco. Durante a leitura do texto, precisamos fazer uma interface entre escrita e "imagens" para podermos contrapor a horizontalidade do texto escrito aos imagéticos pontos que vão formando uma paisagem tridimensionalizada. 
Deve ser pelo fato de possuirmos sistemas perceptivos bastante complexos que conseguimos estruturar essas "flutuações" e extrairmos delas um tipo de informação devolvida em forma de prazer.

Em várias partes da apresentação, as cenas compreendem performances projetadas em vídeo, entrelaçadas pelo trabalho "ao vivo" dos atores e possivelmente em "tempo real", criando um imenso leque simbólico entre as linguagens fílmica e performática. O trânsito entre esses registros dimensiona um contorno interativo estabelecendo vias de mutações entre um "corpo" físico, um corpo digital e um primitivo.

Os movimentos no palco vão adquirindo tamanha velocidade (recreativa) que é difícil não precisarmos migrar para fora do texto e perguntarmos quem ou quais seriam esses “outros" que interagem com tal vicissitude durante toda a ocupação cênica e que relações poderiam ser estabelecidas entre as histórias dramatizadas e as sugeridas nas entrelinhas do trabalho do autor.

As cenas são multiformes. Elas tanto se referem e usam sistemas automáticos da pósmodernidade, simulando inteligências artificiais, intervenção da máquina, vídeo-texto etc., como também referem-se a produções mecanizadas cuja função é substituir antigos "olhares" por modelos mais próximos de uma realidade virtual ${ }^{1}$.

Oficiosamente, poderíamos conceber os movimentos como certas identidades pretendendo processar grande parte dos confrontos entre as diferentes culturas a fim de desafiarem os "mitos" transmitidos por outros tipos de encenações enunciativas.

O Naftazteca é responsável por redimensionar as lembranças e a tradição deixadas pelos ancestrais astecas, ao mesmo tempo que troca de lugar com o Ciber-Vato para conectar diferentes estruturas em uma analogia que remete às diferentes línguas faladas pelos chicanos. Nas fabulações mantidas entre o Naftazteca e as chamadas telefônicas, ele se concede o direito de responder "em línguas". 
De acordo com essas tendências inovadoras, percebemos o gérmen das experiências artísticas de Gómez-Peña funcionando como um tipo de arte telecomunicacional interagindo com a performance e vice-versa, para um tipo de criação intercambiante e, ao mesmo tempo, mutante, entre "essa" e "aquela" direção do espetáculo.

Dentro dessa mesma proposta de interação, das muitas vezes que lemos o texto, poderíamos conceber uma relação entre Norte (os Estados Unidos) e Sul (o México), de forma a se globalizarem e desejando, cada qual, defender sua identidade, pois, de acordo com Gómez-Peña, as “culturas mexicanas e caribenha [...] podem oferecer ao Norte sua força espiritual, sua inteligência política, o senso de humor para enfrentar a crise e sua experiência na promoção das relações pessoais comunitárias" (apud YÚDICE, 2004, p. 339).

Dessa forma, as metáforas da fronteira e da hibridização demonstram, mais uma vez, que se prestam como fonte de inspiração para esse tipo de intercâmbio. A "voz" do "outro" redefine a vida cotidiana evidenciando a incorporação de práticas e alternativas estabelecendo estratégias para legitimar a conexão entre os discursos.

Assim, as outras formas de arte servem para que as produções como são consideradas as chicanas, desenvolvam-se por meio de reformadores artísticos levando seu caráter de arte transnacional e translocal para surpreender os interesses de outras nações.

Expandindo-se como um gás silenciosamente agindo "entre" os espaços presenciais ou da virtualidade, a metáfora da mistura também surge na performance de Gómez-Peña para propor o funcionamento híbrido entre as culturas. Como um ponto de alerta sinalizando a evanescência dos caminhos, a mistura funciona como o manipulador dos aspectos da nossa sociedade que tanto se justapõem, quanto proliferam sentidos, sempre em progresso.

Assim, o contexto dessa performance é dado como sendo o dia de Ação de Graças do ano de 1994, cujo telejornal é interrompido por "duas TVs piratas ciber-Aztec" a fim de transmitir "pontos de vista bizarros sobre a cultura e a identidade americanas direto de uma 
bobagem clandestina de algum lugar entre New York, Miami e Los Angeles. Na realidade, o que os observadores estavam testemunhando, era um experimento na televisão interativa, via satélite" ["two cyber-Aztec TV pirates" - "Transmitting bizarre views on American culture and identity direct from their underground vato-bunker, somewhere between New York, and Los Angeles. In actuality, what the viewers were witnessing was an experiment in interactive television via satelite.”] (p. 111).

Embora a atividade dessa ação seja identificada como uma interação entre movimentos posturais e troca de ambiente, não há como não visualizarmos estados emocionais identificadores dos vários indivíduos no palco.

Apresentando informações externas, esses "seres" trazem vestígios de uma interconexão existente entre as cidades, ou seja, entre as fronteiras de New York, Miami e Los Angeles a espera de eventos vibratórios que façam perturbar, ainda mais, o já perturbado ambiente a ser explorado por todos que queiram fazer parte da atividade. Público e atores juntam eventos implícitos na interação, tornando difícil a percepção a respeito do que estão se referindo naquele momento. Dessa forma, a visualização, ao invés de se mostrar grosseira, transforma-se do começo ao fim, em uma linguagem capaz de comparar a extrema liberdade poética à criação exteriorizada dos acontecimentos na obra de Gómez-Peña.

A introdução de novos atuantes ${ }^{2}$ leva o leitor a perceber uma relação entre as migrações cênicas daqui para ali e de lá para cá. Essa é a tentativa usada pelo autor para que os sentidos dos espectadores e dos leitores se estendam até o ponto de abrangerem ou de agarrarem a organização do conjunto de valores que precisam ser transmitidos por ele, para que as relações e os comportamentos de um grupo social sejam tão modificados que acabem sendo concebidos como outro fenômeno.

Essa seria, portanto, a oportunidade de Gómez-Peña adicionar as suas avaliações acerca da sociedade chicana e norte-americana, assim como suas diferentes formas de 
atividades a serem aceitas pelo espectador. A partir de suas peculiares experiências, GómezPeña convida o público para continuar participando do evento.

Roberto Sifuentes e três de seus colegas diretores de cinema, Adrienne Jenik, Philip Djwa e Branda Miller, tinham combinado com os diretores do programa que aquilo seria "um simulacro de transmissão radiofônica para uma TV pirata atingindo centenas de outras estações espalhadas por todo o país" ["Roberto Sifuentes and I had teamed with filmmakers Adrienne Jenik, Philip Djwa, and Brnada Miller [...] to broadcast a simulacrum of a pirate TV intervention to hundreds of cable television stations across the country”.] (p. 111).

Os diretores do programa tinham advertido sobre arranjarem um título ficcional para o mesmo e que, de tempos em tempos, a TV estaria lutando para obter de volta a transmissão, sem sucesso, pois Gómez-Peña e os amigos teriam o controle da mesma.

Com esse tipo de estímulo disponível para especificar seu trabalho, as atenções estariam voltadas para as interrupções, uma vez que seria tirado do público o programa que estava sendo assistido para, no "lugar", ser colocado uma variedade de fatos sobre os mundos adjacentes. Todo suprimento sensível estimulando os espectadores estaria sendo usado nessa covariação entre teatro e performance, tais como câmera filmadora, frangos correndo no palco, facas, computadores abertos, coração de borracha para ser devorado pelo Naftazteca etc.

A incontável variedade de conflitos geradores de um tipo de acontecimento diferente da composição do dia-a-dia estava ajustado. E isso aconteceu quando, durante "uma hora e meia os 'bandidos ciber' encorajaram os perplexos ouvintes a fim de telefonarem para que os atores respondessem à transmissão, que era uma estranha mistura e política radical, material autobiográfico, e paródias -formatação da TV tradicional sem valor" ["For an hour and a half, the "Cyber-bandits" encouraged perplexed viewers to call in and respond to the broadcast, 
which was a strange blend of radical politics, autobiographical material, and parodies tradicional formats gone bananas".] (p. 111).

Levando essas informações bem mais longe, a atenção que se quer do espectador é o impressionante ponto de encontro para unir esse aprofundamento de informações relativizantes ao "objeto" enfocado. O que Gómez-Peña torna específico é a caracterização das abordagens desses paradoxos descrevendo a variedade de intenções que aborda a produção e a circulação de significados simbólicos. Ele divide, de alguma forma, sua encenação entre reino virtual atingindo a heterogeneidade das relações do agora com o passado, e reino presencial cujos incluídos e excluídos representam as incertezas das culturas por todo o globo. Assim sendo, nada mais problematizador do que intervir em campos supostamente harmonizados para se apropriar de uma (re)definição e lançar as sementes de outras práticas.

De maneira significativa, Gómez-Peña internaliza bens culturais (programas de TV, radiofonia, teatro, filmes) para rearranjá-los como mercadorias colonizadoras do imaginário do espectador. O contato imediato entre os indivíduos não acontece, mas o "encontro" se mostra nas extensões intervalares entre a habilidade de conclamar o público, e a hipótese de tê-lo bem "perto" de si. A postura de cada um é fruto do resultado da elaboração da performance.

Assim, Gómez-Peña domina o espaço e, ao desempenhar sua função performática, funde as relações teatro/literatura com função exploratória. Ao invés de se manter nas superfícies ambientais, ele contata espaços virtuais que se encaixam de modo específico na sensibilidade do público. Gómez-Peña também comenta o seguinte:

nós falávamos inglês, spanglish, francês, e um tipo de esperanto, e pedíamos para nossos espectadores "serem inteligentes, poéticos, e performativos" nas suas réplicas. Nós demonstrávamos uma "máquina chicana da realidade virtual", e recebíamos "respostas ao vivo" via Picture Tel (vídeo telefone) do Café Eletrônico em Santa Mônica, Califórnia. A performance também era transmitida pelas redes de computador via "M-Bone", e aqueles que assistiam pelo ciberespaço podiam interagir conosco, e entre eles, postando comentários escritos e visuais. $(1996, \text { p. 111) })^{3}$ 
Ora, a performance estava sendo transmitida por redes computadorizadas via "MBone" e aqueles que estivessem assintindo pelo ciberespaço, poderiam interagir por meio de comentários visuais ou escritos. Ele ainda comenta que recebem dezenas de chamadas telefônicas, mensagens via computador, e aquilo que seria apresentado no dia eram dois excertos da transmissão (p. 111).

A profusão híbrida que salta aos olhos dessa floresta de signos movimenta caminhos e rotas a fim de serem "navegados" de acordo com nossas escolhas. Não podemos simplesmente "olhar" para o que está sendo apresentado no palco e ficarmos indiferentes, sem ação. Somos convidados a, pelo menos, explorar o ambiente e dele extrairmos saberes com os quais poderíamos interligar muitos outros lugares de entretenimento ou de trabalho. Para onde nos leva essa proliferação de movimentos convocando a nos solidarizar com as diferentes camadas sociais? Quantas vozes acabam subordinadas umas às outras nesse começo de século, produtivo em inovações tecnológicas, artísticas e políticas que se reproduzem em prazos recordes?

Não importa saber sobre a vida cotidiana se a ela não conseguirmos opor o local e o global, a fim de compreendermos que tudo, hoje, acontece de forma interculturalizada. A impotência induzida pela distância já não existe, uma vez que podemos estreitar esses horizontes via NET, pelo ciberespaço, ou pelo rádio e pela televisão. Hoje em dia, podemos até mesmo simular a vida e seus processos de evolução pelo computador.

Segundo Gómez-Peña, somos tratados como clientes virtuais, prontos a estarmos em qualquer lugar, ou, em todos eles, ao mesmo tempo. Alguém nos propõe que mantenhamos um vínculo oculto com todos os outros para permanecermos em diferentes frequências de observação. Senão, que proveito poderíamos tirar desse mundo em que todos se observam a si mesmos numa vigilância constante e midiatizada? 
O que importa para a mídia, hoje, não é a nossa preferência por determinada programação, mas como fazer os espectadores se manterem "conectados" a um determinado programa a fim de serem padronizados e pertencerem a uma massa consumista. Entre todas as modalidades, torna-se relevante considerar os modos pelos quais intensificamos nossa tendência de agirmos em conjunto. Caso consumamos as diferentes manifestações artísticas, este é o sinal para buscarmos favorecer as nossas necessidades propiciando interações com outros sujeitos. Ainda de acordo com Santaella, "grande parte da arte performática em geral desgarrou-se das artes visuais, alinhando-se com o teatro, a dança e a música performáticas em espetáculos e eventos narrativos de larga escala [...]" (2004, p. 72).

Tornando tudo isso válido para o texto em questão, um telejornal estava acontecendo quando, de repente, é interrompido. Uma caligrafia grafitada enche a tela e podemos ler o seguinte: “A TV INTERVENCIÓN PIRATA". Então, um xamã-lutador aparece nessa mesma tela e, num esperanto personalizado pergunta: "ESTIMADO TELEVIDENTE. VOCÊ SE SENTE COMO UM ESTRANGEIRO EM SEU PRÓPRIO PAÍS?" ["ESTIMADO TELEVIDENTE, DO YOU FEEL LIKE A FOREINER IN YOUR OWN COUNTRY?”] (p. 112).

Com essas poucas palavras pode-se experimentar a postura tomada pela personagem em querer debater a questão das identidades e os desencontros que estas provocam quando se quer recompor a desintegração a que estão submetidas atualmente. Mais do que contrapor formas identitárias, parece que o essencial na questão é indagar a possibilidade de os sujeitos transcenderem as periféricas estruturas sociais e se organizarem em tendências mais globalizadoras a fim de estabelecerem uma conexão entre suas "vozes". Sintonizadas em função de uma existência, as "identidades" se percebem donas do poder manipulatório produzindo outras realidades, deslocadas para outras extremidades. Vemos aqui a velha 
questão sobre a mudança nas estruturas de identidades culturais de classe, etnia, raça e de nacionalidade que se fragmentam e se movimentam entre fronteiras menos definidas.

As identidades navegam, criam sensibilidades, sintonizam mudanças e produzem distâncias. Como, então, não se sentir estrangeiro no próprio país de origem? Parece impossível, mesmo porque outras dinâmicas se juntam a esses sistemas e agem em função do desequilíbrio social.

O sujeito inserido nessa ampliação territorial trabalha com possibilidades e, dessa forma, expande o realismo de se sentir estranho, periférico na própria nação, pois acontece, inclusive, de não se adaptar nesse território expandido, desestruturado por tantas outras diversidades. Se antes os "destinos" pareciam bem mais coesos, nítidos, hoje, as relações se mostram indistintas, incógnitas, condicionadas a generalizações quase impossíveis de serem integradas, ou de serem distinguidas como local ou universal.

É por tudo isso que observamos, na peça de Gómez-Peña, uma variedade de referencializações não apenas condicionadas a um corpo transformado tecnologicamente, mas, evidenciado em tantas outras misturas, que fica difícil construirmos uma única certeza. Podemos vivenciar nesses momentos as explorações sociais dimensionadas entre um determinado estranhamento e multiplicidade de outras facetas sociais e culturais das quais não podemos escapar ilesos.

Senão vejamos: o que, na verdade, representam as personagens em cena? Por que câmeras filmadoras e uma tela onde se projetam as personagens da peça misturadas a um filme sci-fi mexicano dos anos 60? Por que "o Ciber-Vato aparece para ser crucificado junto aos equipamentos da TV?" ["El Cyber-Vato appears to be crucified to the equipment".] (p. 112). Estaria implícita aí a metáfora de uma ciência nômade que enxerga os crioulos, os mestiços, como formas diretas apontando para os "objetos" exóticos nos países ocidentais? De que maneira poderíamos pensar sobre a questão? De maneira política e social? 
O fenômeno da hibridização parece, agora, extrapolar as conotações de uma mera caracterização, e as zonas semânticas que dialogam com os diversos fenômenos expostos na apresentação, são como uma prótese, uma extensão tecnológica que pode aderir a esse ou a aquele “corpo". Segundo Santaella,

as dimensões da corporalidade foram radicalmente questionadas. Com Foucault, descortinou-se um campo de investigação relativo à ação das práticas culturais, instituições, saberes e poderes sobre a experiência do corpo. A partir de Derrida e Deleuze, a crise do sujeito e da razão abriram caminho para um modo de pensar destinado a desconstruir a natureza unívoca do sentido e da forma, do ser e do logos. No cerne dessa crise, tratou-se também de redescobrir a natureza intensiva do corpo. (2004, p. 66)

O próprio evolucionismo da performance desenvolve a complexidade simbólica para se produzir as "diferenças" entre os corpos que abalam o próprio "mundo" das representações. Não se trata de negarmos o transitório das mutações, mas de percebermos até que ponto nossos sentidos são submetidos a mudanças para poder captar toda a diversidade simbólica que emana dessas contraditórias posições. Algo teve início nas extremidades de nossa percepção e a memória não deixou de captar o papel estabelecido a cada um dos atuantes no palco. Segundo nos parece, são corpos atravessados pela tradição chicana que fazem supor o prolongamento das funções dos multifacetados "corpos" existentes nos contornos exteriores, intercorporais.

Por meio de um exame mais detalhado percebemos que essas "realidades" estão presentes na atuação quando o Naftazteca afirma:

Boa-noite América pós-NAFTA. Sinto informá-la que esta é uma transmissão de TV pirata. Meu nome é Naf-taz-tec: vendedor trans-cultural, disc-jockey apocalíptico, e bandido informante superhighway, todos em um, dentro, e vice-versa, interrompendo seu coito, como sempre. Estão comigo hoje à noite, os membros da gang-techno do Leste, Ciber-Vato e três frangos mortos doados pela minha tia Rosa. $(1996$, p. 112)

Seria fácil imaginar a interioridade dessas dimensões caso elas fossem apresentadas como espacialidades estáticas, mediadas por uma única fronteira onde dentro e fora somariam 
uma só distinção. Entretanto, a evolução não cessa de se alterar e encontra do outro lado da linha realizações informando sobre outras mutações, outras adaptações.

A América já se encontra em uma posição pós-NAFTA? Isso quer dizer que os acordos comerciais firmados entre os Estados Unidos, Canadá e México, abrindo suas fronteiras para o comércio livre estão desfeitos, ou que o país mais poderoso mostra sua hegemonia mais uma vez e não permite que os outros dois se movimentem com a mesma carga de poder?

Quando falamos em livre-comércio, sabemos que ele traz ganhos quase incalculáveis para as empresas transnacionais em troca de perdas e subjugações para os demais países envolvidos na aliança, inclusive para os países de origem dessa corporação. Não é de estranharmos, portanto, que os resultados das ações provindas desse comércio neoliberal não sejam tão positivos como se divulga. Um ou mais país sempre fica subjugado ao poder econômico-financeiro do mais poderoso.

Ou os Estados Unidos estariam jogando, mais uma vez para as margens externas, o que foi registrado como benefício para aquelas sociedades depois da criação do NAFTA?

$\mathrm{Na}$ atualidade, o livre-comércio está introduzido de tal forma entre as nações de economias radicalmente desiguais, que é difícil não prever consequências prejudiciais para o mais fraco. Não é possível acreditarmos mais uma vez que os neoliberais acreditem que o livre-comércio trará desenvolvimento e progresso para todas as nações envolvidas no processo, e como não têm outra alternativa para justificar tanto lucro próprio, enganam afirmando que o subdesenvolvimento caminha a passos largos em direção ao desenvolvimento após a expansão a nível global.

Parece que o papel dessa atuação é alimentar-nos com questionamentos sociais, políticos, econômicos, e artístico, e fazer-nos interessados em prestar atenção na próxima questão inserida na performance de Gómez-Peña. 
A transmissão é pirateada e, sendo assim, difícil de ser traduzida como algo fidedigno. Além do mais, o prazer de um coito é interrompido pela "voz" de um informante bandido; desconfortável constrangimento deslocando a atenção prazerosa para uma sensação de raiva. Quando estamos nos divertindo, não há dúvida de que ficamos raivosos pela quebra do prazer. O espaço fica esvaziado e outras sensibilidades chegam para explorar o vazio deixado pela capacidade física em andamento.

Em seguida, ao ser empregado novas possibilidades de interação em cena, aparecem a personagem Ciber-Vato e os atuantes frangos. Essas participações encantam, mas, ao mesmo tempo, ditam um ritmo frenético de atuação. Os nossos "olhares" absorvem o enunciado para, em segundos, deslocarem-se para as imaginárias imagens transmitidas na tela. É pedido que a câmera número dois focalize as aves correndo pelo palco, ao mesmo tempo que o Naftaztec anuncia que sacrificaria uma delas, mas, em virtude de ter sido ameaçado de esvaziamento do local pela plateia, ele decidiu poupar-lhe a vida (p. 112).

$\mathrm{O}$ advento dessas profundas modificações no jeito de enfocar a textualidade dirige nossa atenção. $\mathrm{O}$ impacto que elas produzem é atordoante e as tensões no interior de cada cena explodem em várias onipresenças. Embora tenhamos preparado o espírito para incorporar a autonomia de cada movimento em cena, os retalhos plásticos segmentando a sequencialidade da cena, levam-nos à loucura.

Não seria exagero introduzirmos aqui uma outra analogia referencializando o sacrifício do frango ao sacrifício a que o povo chicano está submetido. Ou ainda, não é impossível associarmos o "pedido" de não degola do frango ao pedido de "outras nações" para que os Estados Unidos não degolem os chicanos. Afinal, segundo Torres, "essa consciência nacional diferenciava o chicano dos demais imigrantes norte-americanos, já que originalmente foram os EUA que "vieram" aos mexicanos, ocupando seu território à força" (2001, p. 22). 
Dando-nos a conhecer essa maneira de "viver" e de se deslocar na contemporaneidade, Gómez-Peña demonstra experimentar e sentir os problemas pelos quais passa a classe trabalhadora de seu povo e ele próprio. Além de serem considerados uma ameaça para a cultura dos Estados Unidos, (aliás, como qualquer outro imigrante) eles são descritos como os indocumentados irresponsáveis que tiram os empregos cada vez mais escassos do resto da população (YÚDICE, 2004, p. 294).

Por meio de apresentações como essas, Gómez-Peña vai dando a conhecer o conteúdo cultural que distingue os americanos de outros povos dominantes. Ele mostra a diferença entre os Estado Unidos e o resto da Europa em uma demonstração que reproduz, de maneira simbólica, a hegemonia norte-americana em relação não só aos chicanos e à Europa, mas também, ao resto do mundo.

Em outras palavras, o conceito de hegemonia norte-americana está, de fato, tão enraizado em nossa consciência que é como se outras culturas ficassem sem voz, irreconhecíveis nesse processo global.

Dessa forma, como qualquer outra nação idealizante, a chicana reserva-se o direito de lutar para conseguir sua voz por meio da política nacional ou local. Ela incrementa sua competitividade no campo das artes, das mídias, em seus rituais, numa forma de reprodução de seus interesses que, de outra forma, lhes têm sido negados durante tantos anos.

O próprio Gómez-Peña declarou certa vez em uma entrevista:

Somos excessivos, mas com muito estilo e grande poder de convocação. Aonde quer que vamos, convocamos muitas raças, muitos jovens, um público muito variado. E quanto aos formatos de apresentação, experimentamos aquele do museu vivente. Exibimo-nos a nós mesmos como humanóides exóticos: às vezes representamos meros espécimes etnográficos e outras ocasiões adotamos identidades híbridas sugeridas pelo mesmo público, o qual nos converte em Frankensteins multiculturais. Em nosso laboratório bizarro de experimentação interdisciplinar tentamos levar à prática aquilo que o antropólogo mexicano Roger Bartra chamou "a construção do selvagem artificial”, criatura mítica que o Norte precisa demonizar para racionalizar, assim como seu ethos colonizador [...] e seu racismo. (disponível em <www. jornada.unam.mx/2005/ene05/050131/a03n1cul.php>). Acesso em: 07.jun.2005. 
Diante disso, a cultura chicana está impregnada de especificidades que lhe permitem projetar uma consciência social falando ao povo como aquele que revoluciona e que ganha a atenção não só dos Estados Unidos, mas dos negros, das mulheres, de associações, de outras classes, de outras fronteiras. Os chicanos não são mais prisioneiros de sua própria vizinhança. Eles desfrutam, por outro lado, de um movimento que os coloca ora nessa comunidade, ora naquela outra, sempre demarcando novos limites a serem transpostos.

Seria tudo isso o que está expresso na próxima cena da peça?

\begin{abstract}
Hoje à noite vocês estão prestes a testemunhar um milagre da techo-rascuachismo, um verdadeiro exemplo da arte chicana pós-CNN, que, qué?! [...] Sim, eu demonstrarei ao vivo pela televisão nacional minha máquina chicana da realidade virtual. Com esse novo sistema chamado TECHNOPAL 2000, posso transformar minhas memórias em imagens de vídeo, ipso facto, o que significa que posso recuperar qualquer episódio de minha vida, qualquer performance com a qual estive envolvido [...] ou qualquer evento histórico envolvendo minha família e minha raça - as comunidades chicano/mexicanas nos Estados Unidos - que, qué?! (1996, p. 112-113)
\end{abstract}

O desafiante efeito da fala que se torna impactante, nesse momento, parece inerente aos integrantes de uma sociedade tão conflituosa. Teria a memória do povo chicano sido realmente transformada em algo tão travestido de modernidade a ponto de estar disponível em vídeo, ou estaria essa “imagem” caracterizando a memória que foi, de maneira forçada, obrigada a se enterrar com a ancestralidade do povo para que o mesmo pudesse ser aceito numa outra sociedade tão diferenciada, tão mais poderosa que a sua? Ou estaria Gómez-Peña espalhando para o mundo uma verdade que já é gritante: os mestiços estão se tornando, em boa parte do mundo, uma força notadamente diferenciadora, tanto política quanto culturalmente (YÚDICE, 2004). Nesse ponto, podemos identificar a luta e, ao mesmo tempo, o esforço de os chicanos se desvincularem da tirania da razão norte-americana. Já não querem pertencer à classe dos colonizados, mas sim, desfrutarem das mesmas articulações póscoloniais.

Testemunhamos, portanto, os inúmeros desempenhos dos chicanos, suas interessantes manobras para poderem se posicionar em diferentes camadas da cultura intelectual norte- 
americana. A própria Anzaldúa afirma que ou seria uma mulher de letras, ou não seria ninguém. O papel de dona-de-casa é que não aceitaria desempenhar, nem o de prostituta nas ruas, sequer o de freira em um convento.

Os chicanos produzem, com isso, um pertencimento de se identificarem com aquele que, embora convivendo com a contemporaneidade, se orgulha de defender o passado histórico mexicano. Nada mais justo, portanto, do que expressarem todos seus sentimentos por meio das diferentes formas artísticas.

Dentro de uma estrutura globalizada como a atual, os chicanos levam suas culturas populares, sua produção artesanal assim como a arte do grafite nos Barrios, às mais diferentes esferas intelectuais ou acadêmicas. Segundo Yúdice,

\begin{abstract}
O novo trabalho interdisciplinar sobre a cultura fronteiriça chicana passou por várias etapas - desde um reconhecimento nacionalista dos fatores relativos ao gênero, raça e orientação sexual até um reconhecimento híbrido - e constitui, não obstante, um cânone "local" que abarca desde o romanceiro fronteiriço, considerado por Américo Paredes como o principal fermento da identidade cultural em seu livro With his pistol in his hand: a border ballad and its hero (1958), até a "escrita fronteiriça mestiça" de Gloria Anzaldúa e outros escritores e críticos contemporâneos das décadas de 1980 e 1990, passando pela poesia, romance, teatro popular e murais das décadas de 1960 e 1970. (2004, p. 341)
\end{abstract}

O resultado dessa cultura em expansão não poderia, portanto, resultar em outra coisa senão em benefícios econômicos. Os chicanos tanto angariam fundos vendendo exemplares de suas obras, quanto cobram ingressos do público visitante. Eles tanto têm seus próprios espaços de negociação, quanto fazem parte de instituições ou organizações financiadas pelo governo. Dessa forma, não há como eles não atenderem a uma série de exigências do público, tanto quanto não deixarem um "registro" dando a conhecer a história da etnia e da própria complexidade cultural a que estão submetidos, como acontece nessa performance de GómezPeña.

E mais, para enfrentar a crise, os artistas promovem relações pessoais e comunitárias que os inserem numa identidade fronteiriça revelando, ao mesmo tempo, pertencerem, também, a um conjunto de outras categorizações identitárias. Gómez-Peña afirma que sua 
identidade tem, hoje, "múltiplos repertórios". Ele afirma ser mexicano, mas também chicano e latino-americano; na fronteira chamam-no de "chilango" ou "mexiquillo"; na Cidade do México nomeiam-no "pocho" ou "norteño"; na Europa "sudaca”; os ingleses, "hispânico" ou "latino"; e os alemães, muitas vezes, confundiram-no com um turco ou italiano (YÚDICE, 2004, p. 342).

Pertencendo a essa variedade de encontros, Gómez-Peña demonstra por meio de sua personagem que na "próxima hora e meia de apresentação, vocês terão acesso direto à labiríntica mente de um mexicano [...] um artista mexicano performático ilegal com ilimitado acesso à tecnologia artística, ao vivo, na televisão nacional" ["For the next hour and a half, you will have direct acces to the labyrinthic mind of a Mexican [...] An illegal Mexican performance artist with unlimited access to state-of-the-art technology, live on national television!!’”] (p. 113).

As indagações que podemos fazer sobre essa "fala" de Gómez-Peña leva a atentarmos para os novos espaços de intermediação com os quais a heterogeneidade artístico-cultural se articula. Não se trata de considerarmos apenas os "labirintos" locais de determinada cultura, mas sim, de nos questionarmos sobre estruturas artístico-sociais ampliadas, resultantes desses sujeitos coletivos. Possuidores de uma consciência própria, os chicanos se "veem" e se valorizam como o exemplo produtor de outras geografias, assim como novas paisagens culturais nesse emaranhado sistema mundial pós-moderno. Para sua lógica interna, eles se percebem em eterno conflito, mas ultrapassando fronteiras que os diferencia nesse entrelaçamento cultural, como conhecedores de outros mapas, outras histórias.

Os chicanos já não permanecem apenas como membro de uma clientela imaginada, mas dão-se a conhecer, inclusive, por invasão de privacidade. Eles se tornam vigiados, disponíveis para serem "decodificados" por meio de uma significativa rede conectada mundialmente, parecendo não haver muitas outras alternativas, senão deixarem-se invadir 
com uma frequência assustadora. Como se tivessem sentados à frente de um "painel" eletrônico, "manipulando" as artes e sendo por elas "manipulados", eles se transformam em peças de entretenimento por meio de agentes distantes. O lugar de produção pode ser Los Angeles, Cidade do México, Argentina ou qualquer estúdio disfarçado (re)transmitindo de um outro local, para este aqui, ou deste para o outro.

É dessa forma, portanto, que não nos assusta todas essas mudanças instáveis e entrecruzadas das passagens de um milênio a outro. As novidades artísticas surgem tanto das "misturas desconcertantes" do "artesanato indígena" exposto em "butiques modernas", quanto das "passarelas, nas estréias cinematográficas e nas inovações informáticas" (CANCLINI, 2003, p. 171).

O aumento dessas posições podem levar, dessa maneira, a que a arte de Gómez-Peña ocupe espaços intervalares fazendo nossa imaginação decolar da ancestralidade do povo chicano para o pós-moderno. Ele relata em cena que os astecas eram um povo muito festivo: eles dançavam, faziam teatro, cantavam e que praticavam, também, um tipo de jogo parecido com o squash, com o futebol mas, com uma pequena diferença: o time que perdesse era sacrificado aos deuses.

O autor acrescenta que seu dilema vivendo nos Estados Unidos é semelhante: se ele perde, morre. "Um passo em falso, e morro" ["Un paso en falso e me muero"] (p. 114). Ele comenta, além de tudo, que a questão da "identidade tornou-se o principal assunto da nossa arte" ["identity has become the main subject of our art"] (p. 115).

Talvez mais do que qualquer outra, essa questão mostra, por meio das performances de Gómez-Peña, a concordância do povo chicano em apropriar-se de suas tradições e se abalar quando alguma coisa ameaça mudar seus princípios de práticas culturais. As dificuldades que enfrentam são cada vez maiores pelo fato de serem considerados uma classe subalterna e, para 
reverter esse quadro, necessitam manter uma política cultural que transcenda o nacional e que se movimente em outras realidades.

Muitos outros artistas chicanos se inserem nesse novo jeito de lidar com identidades e uma vez inseridos aí, tomam posse desse espaço, até mesmo pela variedade artística, como acontece com Gómez-Peña. Esse foi o meio que eles elegeram para caracterizar a miscigenação chicana, ou seja, a ansiedade que se mostrava sempre presente em querer definir a raça, se transformou em uma forma de orgulho nacional pelas vias do trabalho e pelas transformações em sua forma de agir.

Como podemos observar, Gómez-Peña tem uma atenção toda especial quando trabalha com o tema identidade em suas apresentações e essa sua forma de criar demonstra o fato de ele não se alienar das questões sociais que envolvem os chicanos. Ele pertence a muitas identidades fronteiriças e, por isso mesmo, precisa empreender contraditórias encenações tentando expor e contribuir para a reconstituição da identidade chicana. Gómez-Peña adota essa linha como a principal de sua argumentação e sustenta que precisa, na verdade, fazer escolhas para melhor se adaptar às suas necessidades e às verdades dos chicanos.

Nesse sentido, parece ser inerente a todo sujeito moderno a necessidade de se sentir identificado com essa ou aquela nação. Caso contrário ele "experimentaria um profundo sentimento de perda subjetiva" (HALL, 2003, p.48).

Parece ser esse, portanto, o paradigma no qual Gómez-Peña se "vê" inserido para buscar os "sentidos" que as culturas nacionais representam e para construir a base de seu discurso, a fim de unificar a raça chicana. Embora uma cultura não tenha apenas um ponto de lealdade ou de união, ela precisa de uma determinada produção para dizer "sou isso", ou "sou assim". Ainda segundo Hall, "as culturas nacionais, ao produzir sentidos sobre a nação, sentidos com os quais podemos nos identificar, constroem identidades" (2003, p. 51). 
Diante de análise tão lúcida, não podemos nos esquecer de que a variedade de práticas inclusas no desempenho da pós-modernidade, faz as referências identitárias descentralizaremse e multiplicarem-se em determinados tipos de realidades encontradas na sociedade. Deparamo-nos com tamanha quantidade de transformações suportadas pela tecnologia que, ao circularmos anônimos ou plugados em redes, simulamos encontros diretos com novas experiências escritas no desenvolvimento pós-moderno.

$\mathrm{Na}$ era digital, nossas certezas atravessam um processo de desaparecimento. A afirmativa, aliás, certamente alimenta as contraditórias realidades expressivas da pósmodernidade e, assim, seria bom colocarmos o seguinte posicionamento: para assimilarmos o discurso de Gómez-Peña, precisamos aprofundar nossos interesses voltados para esses movimentos e suas interrogações a fim de aceitarmos que as possibilidades tecnológicas nos permitem construir um paralelo imprevisível entre chicanismo, tradição e mundo pósmoderno. Em outras palavras, trata-se de considerarmos as perspectivas do autor como um importante modelo de experiências transnacionalizando a cultura chicana que, entre a construção de "saberes" e de "fazeres", legitima-se como os múltiplos da compreensão por meio de práticas discursivas. Mais do que ninguém, Gómez-Peña produz suas “verdades" por meio de um tipo de poder capaz de produzir discursos dotados de efeitos bombásticos.

Sendo assim, esse sujeito é aquele da oralidade misturado ao sujeito da cultura, e ao da virtualidade pós-moderna, formando nas "entre" dinâmicas com o computador, a heterogeneidade da tríade "guerra", "poder", e "discursos éticos".

Hoje, o novo sujeito caracteriza-se pela valorização da própria autonomia, nascido com o perfil do internauta na era da revolução eletrônica, intensificado pela cultura digital. Assim, estaria morto o antigo sujeito em Gómez-Peña para que em seu lugar tivesse nascido as muitas "vozes", anunciando a dissolução das fronteiras entre sujeito e objeto, eu e outro, virtual e atual, ver e ser visto? 
São essas ambivalências que mostram a necessidade de reconfigurarmos as oposições propostas pelo autor a fim de entendermos o que está acontecendo, e suas consequências mais dramáticas. Segundo Santaella,

as tecnologias teleinformáticas não se compõem só de máquinas, mas também de infra-estruturas intelectuais e institucionais que as inventam e distribuem. Portanto, além de partícipes, somos também responsáveis pela forma cultural com que a tecnologia se encarna psíquica e socialmente no contexto especifico que é o nosso e ao qual pertencemos. (2003, p. 134)

O desenvolvimento de forças externas a nosso corpo (a maquinaria) é, na verdade, um prolongamento do corpo. O crescimento de nossas capacidades mentais está, sem sombra de dúvidas, interconectado ao desenvolvimento das tecnologias. Começamos há muito tempo a ser encarados como um continuum híbrido entre humano e máquina cujo limite leva a consequências não imaginadas. Um exemplo disso é a nanotecnologia que, a serviço da ciência tecnológica, pode viajar ao longo dos vasos capilares e entrar numa célula viva para conserta-lhe possíveis desarranjos (SANTAELLA, 2003, p. 241)

É admirável, portanto, que Gómez-Peña tenha todo esse tipo de conhecimento, como podemos notar no fragmento do texto intitulado "PERFORMANCE, TELEVISION AND CYBER-SPACE”, em que assistimos à seguinte cena:

O Naftzteca: (ao vivo na tela, gira botões e alimenta pimentas chili dentro de uma máquina, expressando-se numa voz computadorizada): Então agora, vamos falar sobre a TECHNOPAL 2000, uma tecnologia originalmente inventada pelos maias com a ajuda de alienígenas de Harvard. Seu CPU é controlado por pimentas chili Habañero, combinado com esta ou DAT tecnologia, mais um relógio de medição de velocidade de 200.000 megahertz! (1996, p. 119) ${ }^{6}$

A convergência das formas de hibridização está, mais uma vez, presente na performance de Gómez-Peña. Nesse exemplo, além da mistura de linguagens, dos meios de comunicação e seus sistemas, da internet e da web, são enfatizadas as misturas dos espaços virtuais com os presenciais. As imagens são acionadas pela personagem usuário das tecnologias que, ao interagir com os diversos meios disponíveis aí, faz resultar a interação 
entre criador e criatura. O dilema não se desfaz, mas somos capazes de associar esses saberes a momentos em que um novo tipo de arte emerge.

Dessa forma, podemos partir do pressuposto de que, pela integração de funções estéticas, tecnológicas, culturais e publicitárias interagindo mutuamente, há a valoração da performance desconectada de sua função objetal, ou seja, das "mensagens visuais" em constante mutação, para os signos serem (re)elaborados e integrarem novas representações. Previsivelmente esses resultados são o suporte para os outros recursos que Gómez-Peña teve de lançar mão quando, ao sair de um único espaço de produção, ao abandonar antigos sonhos, precisou colher flagrantes da vida diária e transformá-los a uma "velocidade de 200.000 megahertz", em desafios materializados em um corpo "humano" ou "cibernético".

Nessa medida, algumas outras falas espalhadas ao longo do final da apresentação fotografam a contínua desconstrução daqueles princípios estéticos considerados válidos desde o Renascimento:

\begin{abstract}
Okay, homem, deixa-me mudar o programa ... Você gostará deste. É chamado "A fuga na fronteira 2000" [...] Você está agora num lindo prado. É o pôr do Sol e nuvens alaranjadas formam cenas bíblicas no horizonte [...] É meu TIO. Tio, o que você está fazendo aqui? [...] É um helicóptero da migra! A patrulha da fronteira. Corra tio, corra [...] Lembre-se: você pode falar na língua que quiser. Alienígenas ilegais são bem-vindos [...] Mas o que eu quero saber, realmente, é que diabos quem é você? Quero dizer, você está nos Estados Unidos legalmente? [...] Meu nome é Prigone, o representante mexicano no Vaticano. O que estamos testemunhando é o milagre atual do nascimentos da religião tecnológica. Eu proclamo a ambos como os Santos Profetas Sagrados do Estático [...]

(a seção pré-produzida vagarosamente toma posse da imagem ao vivo, até que o Naftazteca e CiberVato são transformados, por completo, em coisas estáticas, tornando-se os Patronos Santos do estático. As crenças começam girar). (1996, p. 121 a 125) ${ }^{7}$
\end{abstract}

A partir dessa cena, ou melhor, somando tudo isso na obra de Gómez-Peña, não são poucos os impactos que esses dispositivos causam em qualquer um de nós. É como se ele quisesse mostrar, ao mesmo tempo, os novos ambientes sócio-culturais inaugurados com o advento da industrialização, da explosão demográfica que obrigou muitos milhares de migrantes procurando outros espaços, assim como o aumento dos grandes centros urbanos, e o 
poder revolucionário da Internet, culminando com o desmoronamento de antigas estruturas de espaço e tempo, tanto quanto de figuras definidas e reconhecíveis.

Como consequência, essas configurações cederam lugar a um espaço tridimensional ampliado onde começo e fim foram abruptamente cerceados. O certo é que já existem outras formas de vidas artificiais agindo de maneira espontânea e até mesmo autônoma, por meio de processos produtores do novo, assim como a nova inteligência da pós-modernidade (SANTAELLA, 2004, p. 101).

A denominação geral que poderíamos dar a esse complexo conjunto de dados pouco importa, uma vez que as representações imagéticas de tais funcionalidades ficam a cargo de cada leitura efetuada nessa ou naquela época. Cada uma das leituras pode inaugurar outras "histórias locais", ou seguir uma ideologia traduzida pela tendência de novas subjetivações. Na base desse processo está a reflexividade formadora de bases identitárias chicanas, cada vez mais integrando e refletindo um estilo de vida, um hábito, um critério da sociedade, uma autorealização.

Assim, por meio desses processos de construção, uma outra imagem da subjetividade de Gómez-Peña ainda nos é dada pelo "nascimento da religião tecnológica". Estaria ele universalizando o princípio de que as "produções" do espírito também se "maquinizam", ou, o autor estaria sugerindo que elas estão abertas a se "coisificarem" como outro bem inútil da loucura tecnológica? Ou estaria Gómez-Peña inventando um outro tipo de sujeito que, para evitar a angústia, seria "confeccionado" pelo ready-made e oferecido, aos montes, para outro tipo de sociedade cada vez mais diferente de si mesma e da massa?

Talvez o autor queira excitar o "leitor/espectador" a experimentar uma nova sensação, consumida na extensão ilimitada do excesso das sensações, ou dar mostras do efêmero da vida pós-moderna produzido pelas diversas tentações que só duram até serem substituídas por 
outras. Ou, então, dispor modelos corajosos de ajustamento pessoal ou de valores mercadológicos, necessários nos tempos atuais.

Visualizamos na obra de Gómez-Peña, determinadas compensações sendo efetivadas para resistir aos comandos de uma ideologia hegemônica norte-americana. Segundo Foucault (1984), se a vida é tomada como objeto político, ela se volta, com certeza, contra o sistema que pretende controlá-la. Assim, a vida passa a constituir-se como o alvo das lutas políticas mesmo porque é essa luta que está sob a forma de direito à vida, à saúde, às necessidades, aos prazeres.

Tomando por base essas questões, podemos superpor, também, uma última organização no texto performático de Gómez-Peña. Como fruto desse estranhamento, nossos olhares adquirem outras visões e podemos perceber que, embora o homem tenha necessidade de dar respostas e satisfazer o corpo, a natureza da pulsão não é apenas produzir esses objetivos, mas sim, ficar dando voltas incansáveis para atingir aquele objeto perdido que, na verdade, nunca foi ganho.

$\mathrm{Na}$ tentativa de alcançar outras práticas, o desejo se dispõe a percorrer uma longa lista de procuras para atingir o lugar considerado o último fundamento de suas prioridades.

Talvez seja essa busca o obstáculo que impede o círculo de ser fechado e de produzir, dessa forma, a crença de que o desejo, a satisfação e a felicidade sejam alcançados em plenitude. Como isso é um logro do Imaginário, o humano tem no gozo, no prazer, um lugar sem lugar. De acordo com Santaella, "Dessa falha brota o desejo, um desejo sem parada, um deslocamento contínuo, pois o objeto que causa o desejo é objeto pulsional, irremediavelmente perdido" (2004, p. 148).

De acordo com as imagens projetadas em cena, podemos estabelecer um paralelo entre Gómez-Peña e sua arte: ele cria, de forma incansável, tensões e espaços de ação que, muito provavelmente, nunca terão um ponto final. A circularidade por ele projetada na sua obra é 
uma impressionante circularidade, sempre em progresso. Suas pesquisas estão a todo momento gerando outras considerações, fazendo de seus experimentos a circulação procurando o objeto talvez irremediavelmente perdido, para sempre.

Entretanto, esse avesso do problema é somente um começo: o começo de uma estrutura particular que torna irredutível a elaboração de uma fluidez desdobrando-se na coerência de um projeto que assume o aspecto de outros encontros, todos, retomando o início, mais uma vez. Assim, qualquer elemento, ou qualquer combinação coerente serve-lhe de essência para seus efeitos, disponíveis para serem explorados pela sua arte. Mais do que nunca, Gómez-Peña mobiliza nossa energia psíquica e, nessa constante, nos faz identificar ideias para além de seus jogos de palavras.

\section{NOTAS}

1- Segundo Santaella, "em sentido mais amplo, o termo "virtual" passou a significar qualquer coisa que acontece no computador. A palavra "virtualidade" penetrou no imaginário popular como uma metáfora para se referir ao espaço dentro do computador e mesmo fora do computador. O uso do termo se ampliou tanto que passou a conotar qualquer espécie de fenômeno computacional, do e-mail a grupos de trabalho, de livrarias virtuais a universidades virtuais" (2003, p, 195).

2- O atuante, de acordo com Cohen, não precisa ser um ser humano, ou seja, o ator. Pode ser um boneco, ou até mesmo, um animal. O conceito de "atuante" pode ser radicalizado de tal forma, que ele pode ser, inclusive, "desempenhado por um simples objeto, ou uma forma abstrata qualquer" (2002, p.28).

3- "We spoke in English, Spanglish, French, and a type of esperanto, and we asked our viewers "to be intelligent, poetic, and performative" in their responses. We demonstrated a "Chicano virtual reality machine", and received "live reports" via Picture Tel (video telephone) from the Electronic Café in Santa Monica, California. The performance was also transmitted over computer networks via "MBone", and those watching in cyberspace could interact with us, and with each other, by posting written and visual comments". (GÓMEZ-PEÑA, 1996, p. 111)

4- "Good evening post-NAFTA America. I'm sorry to inform you that this is a pirate TV broadcast. My name is El Naf-taz-tec: cross-cultural salesman, discjockey apocalíptico, and information superhighway bandido, all in one, within, \& vice versa, onterrupting your coitus, as always. With me tonight are Esat Los techno-gang member Cyber-Vato, and three dead chickens donated by my Aunt Rose". (GÓMEZPEÑA, 1996, p. 112)

5- "Tonight, you are about to witness a miracle of techno-rascuachismo, a true example of post-CNN Chicano Art, qué, qué?! [...] Yes, I will demonstrate live on national television my Chicano virtual reality machine. With this new system, called TECHNOPAL 2000, I can turn my memories into video images, ipso facto, meaning that I can retrieve any episode of my life, any performance I was ever involved in [...] or any historical event involving my family and my raza - the Chicano/Mexicano communities in the U.S. - qué qué?” (GOMEZ-GÓMEZ-PEÑA, 1996, p. 112-113) 
6- "El Naftazteca: (live on screen, turns knobs and feeds chili peppers into a machine, speaking in a computerized voice) So now, let's talk about the TECHNOPAL, 2000, a technology originally invented by the Mayans with the help of aliens from Harvard. Its CPU is powered by Habañero chili peppers, combined with this or DAT technology, with a measured clock speed of 200,000 megahertz!". (GÓMEZ-PEÑA, 1996, p. 119)

7- “Okay man, let me change the program ... You'll like this one. It's called "BorderScape 2000” [...] You are now in a beautiful meadow. It's sunset and the orange clouds are forming biblical scenes on the horizon [...] It's, it's my UCLE! Tio, what are you doing here? [...] It's a migra helicopter! The patrol, ese. Tio, run, run! [...] Remember: You are allowed to speak un any language you wish. Illegal aliens are welcome [...] But what I want to know is, who the hell are you really? I mean, are you legally in the U.S.? [...] My name is Prigone, the Mexican Vatican representative. What we are witnessing is the actual miracle of the birth of techno-religion. I proclaim you both to be the Holy Prophet Saints of Static!

(The preproduced section slowly takes over the live image, until El Naftazteca and Cyber-Vato are transformed completely into static, becoming the Patron Saints of Static. The credits begin to roll'. (GÓMEZ-PEÑA, 1996, p. 121 a 125) 


\section{Considerações finais}

As lições que Gómez-Peña e Anzaldúa nos deixam ao abordarem o passado de sua "nação" comunicam-nos o esforço que eles despenderam para superar valores estabelecidos pela hegemonia norte-americana, pois esta considerava os chicanos a marginalidade desligada de qualquer integração sócio-cultural. Treinados para contraporem-se a essa determinação, os autores se organizaram para usar informações que atendessem a um contexto ou a um pano de fundo que os conectassem à tradição asteca, ao mesmo tempo que consideravam suas diferenciadas produções, o núcleo de transformação para reconstruírem um pensamento crítico.

Várias dessas atividades introduziram mudanças diretas na implantação de sociabilidades entre Estados Unidos e México, pois elas produziram encontros que possibilitaram medidas para estreitar as relações da política cultural entre os dois países. Com eficácia, Gómez-Peña e Anzaldúa puderam estabelecer um trabalho possível com o passado histórico e a tradição, embora tenham colocado interrogações acerca do futuro que puderam multiplicar-se em modernidades para romper com esse mesmo passado. E ainda, sabendo que poderiam estabelecer uma relação entre passado histórico e a sociedade do presente, os autores conquistaram uma posição revolucionária capaz de modernizar a literatura chicana reconhecida, assim, como os argumentos válidos demonstrando perspectivas de resistências.

Dessa posição assumida, aventuraram-se por caminhos que os levaram a territórios imaginados, assim como a participarem e a aceitarem esbarrar em novas travessias, as fronteiras físicas e metafóricas, pois Anzaldúa nos comunica sua ficção de maneira autobiográfica, e Gómez-Peña nos acena com formas parecidas às da autora.

São diversos os caminhos que os autores assumiram para resgatar as histórias de sua tradição, ou em outras palavras, além de toda essa produção, eles quebraram o cânone literário 
para estabelecerem e se firmarem como escritura, deixaram a condição marginal a que estavam submetidos, e de maneira visível, marcaram a apropriação de seu espaço, tanto quanto levaram a afirmação de sua importância por meio de manifestações artísticas. Longe de seus textos estarem emergindo como algo inocente, tudo aquilo que Anzaldúa e GómezPeña escrevem serve para apontarmos e reinterpretarmos o caráter da identidade de uma Raza revolucionária.

Como sabemos, Anzaldúa e Gómez-Peña se apoiam em suas narrativas e o contato com as novas condições de cidadania desempenhadas em solo norte-americano, não deixa de produzir um efeito de mudança para a aquisição de um avanço para que saiam da condição de subdesenvolvimento a que estavam relegados. As políticas de desigualdades eles superaram com projetos de conciliação e políticas culturais de reconhecimento. Hoje, já se publicam obras de chicanos e latinos nos Estados Unidos e há estudos em disciplinas intituladas Chicano/a Literature. Segundo Anzaldúa,

\footnotetext{
Nos anos 60 eu li meu primeiro romance chicano. Foi a Cidade Noturna, de John Rochy, um texano gay, filho de pai escocês e mãe mexicana. Durante dias fiquei imaginando, atordoada, que um chicano podia escrever e ser publicado. Quando li Eu sou Joaquim, fiquei surpresa de ver um livro bilíngue escrito por um chicano e ser impresso. Quando vi poesia escrita em Tex-Mex pela primeira vez, um sentimento de puro júbilo passou por mim. Senti que nós realmente existíamos como um povo. (1999, p. $81-82)^{1}$
}

A partir daí, um número incontável de instituições artísticas e culturais começaram a acreditar na literatura chicana e deram chances para os chicanos continuarem com experiências investigativas acerca do chicanismo. Erguem-se restrições a essas pesquisas, mas a força engajada nessa luta, resiste às provocações e segue adiante.

Também se pode ligar essas considerações ao fato de Anzaldúa e Gómez-Peña revelarem a ansiedade que demonstravam sentir quando se viam submetidos a conflituosas privações que lhes restringia a circulação na sociedade além e aquém das fronteiras. Os autores contribuem, agora, para o sustento da literatura chicana naquela região e transmitem 
informações e gostos que influenciam a geração de novos artistas e escritores, além de entreterem e mediarem a origem de conexões entre a literatura clássica e a pós-moderna.

Essa nova era emancipatória implícita no jeito de os autores enunciarem suas perspectivas político-culturais em defesa de sua história, não se trata de uma nostalgia, mas sim, do resgate histórico que não lhes permite ignorar a necessidade da constituição de um povo chicano.

Associados a muitas atividades na integração multimídia, os textos de Gómez-Peña e Anzaldúa exibem inovações simbólicas que promovem as indústrias culturais chegando a atingir centros opacos de manifestações culturais assim como aqueles que se fecham a mudanças. Eles, os textos, conseguem se expandir em redes globais de serviços sócioeconômicos, pois reestruturam o mundo fragmentado após a queda de sistemas hegemônicos de funcionamento. Uma prova dessa afirmação é o fato de os chicanos terem se expandido em redes nacionais e internacionais de comunicação e se firmado como grupo. Produziram-se condições de entretenimento e de pesquisas com esses textos, e o registro dos fatos informam e acumulam estratégias de serviços. Senão vejamos o seguinte comentário de Gómez-Peña:

\footnotetext{
EM FEVEREIRO DE 1995, O PRIMEIRO ESTÁGIO DE UM PROJETO PERFORMÁTICO BINACIONAL chamado "Terreno Perigoso/Zona Perigosa", foi completado. Durante todo um mês duas semanas em Los Angeles e duas na Cidade do México - onze artistas experimentais cujo trabalho desafia noções esteriotípicas e/ou oficiais de identidade, nacionalidade, linguagem, sexualidade e processo criativo, trabalharam juntos diariamente. Representando o México estavam Lorena Wolffer, Felipe Ehrenberg, Eugenia Vargas, César Martinez e Elvira Santamaría; da Califórnia vinha Elia Arce, Rubén Martinez, Nao Bustamante, Luis Alfaro, Roberto Sifuentes, e eu. Escolhidos pelos curadores e produtores, Josefina Ramírez e Lorena Wolffer, esse grupo era tão eclético e diverso quanto nossas duas culturas (a chicana e a mexicana). As performances eram apresentadas na Universidade da Califórnia, em Los Angeles (UCLA) e no Ex-Teresa Arte Alternativa (Cidade do México).

O trabalho da performance que desenvolvíamos cobria um vasto espectro, indo das mais íntimas ações rituais às mais confrontantes performances ativistas; incluindo tablados vivos, apresentações de cabarés, poesia falada, rituais apocalípticos, e "intervenções" de rua. Nossos objetivos (pelo menos aqueles que expressávamos conscientemente) eram: criar arte juntos (arte de fronteira é colaborativa por natureza); abrir a caixa de Pandora das relações Norte/Sul e libertar os demônios da fronteira; destruir tabus; [...]. $(19996, \text { p. 169) })^{2}$
}

Como vemos, o debate que os autores estabelecem ao longo de suas obras aponta o enfoque político que ambos reuniram na forma e no conteúdo dos textos para traçarem a 
relação crítica e consciente de eliminarem julgamentos de superioridade sobre sua arte literária. Eles desestabilizam planos canônicos, reúnem outros fragmentos históricos e culturais, além de determinarem o caráter de um todo ativista. A partir dessa situação, os textos de Gómez-Peña e Anzaldúa se estendem como uma intertextualidade paródica em uma declarada relação entre o antigo e o novo. Fazem parte da lista dos novos emergentes. Os autores, então, utilizam-se de suas produções para expressarem a passagem da objetividade do passado histórico para as mídias do presente. Eles aplicam suas produções interagindo com a globalização e conseguem equilibrar-se no intercâmbio internacional como alguns dos escritores mais lidos das Américas.

Além de tudo isso, eles presenciam sensibilidades em sintonia com a Europa e mantém um meio de comunicação em curso, sempre em mudança, referencializando os acontecimentos que, de maneira inevitável, estão envolvidos com suas ideologias e suas "vozes". Com isso, os autores inovam configurações estabilizadas e garantem a coesão para a sobrevivência da cultura e da arte chicanas. Às suas experiências multiculturais vêm se juntar tantas outras vozes latinas que poderíamos afirmar que parte dessas histórias se expandem para o resto do mundo. Eles atuam em nosso imaginário e nos falam por meio de uma arte em forma de produção literária. Nem mesmo os materiais de ofertas, as inovações comerciais, ou a crítica e a incerteza, conseguem detê-los.

De maneira análoga, os autores apresentam um modelo de reciprocidade dialética quando objetivam dar mostras das sobreposições de interesse entre teorias, suas realidades e a arte literária. Eles concentram explorações nas contraditórias fronteiras que efetivam sua identidade baseada no tripé tradição, barrios, fronteira(s), símbolo dos modelos de sobrevivência de um poder antes relegado à marginalidade.

Anzaldúa e Gómez-Peña buscam seu lugar de pertencimento. O que antes era pensado como apenas um lugar de localização, hoje, com a globalização de seus textos, é preciso 
reimaginarmos essa posição geográfica e geocultural. Assim, eles vivem, residem e viajam dentro da cidade e entre cidades. Oferecem respostas nada simples e processam mecanismos de integração interna entre as pessoas do grupo como um território claramente conectado a focos de redes econômicas das grandes cidades. Já não é sem tempo que eles redefinem a maneira e o sentido de ser urbano. Isto é, eles desenvolvem desafios que nos fazem acreditar que as verdades são plurais conduzindo ao reconhecimento não de um único texto, mas de tantas outras contextualizações quantas forem possíveis para se destruir aquelas definições hegemônicas que consideravam outros questionamentos sobre quem fala em um texto, a “voz" desestruturada para apenas referencializar fatos do dia-a-dia.

Gómez-Peña e Anzaldúa são conquistadores que se organizaram para movimentar um núcleo geográfico, político e cultural que se achava constituído de apenas alguns pareceres evocando o passado pré-corteziano. Eles estabeleceram modos de agir e interagir que nos induzem a reconhecermos o espaço de um patrimônio cultural perspectivizando a autonomia que dá mostras de sua importância. Tanto um quanto o outro sintetiza os componentes hispânicos e indígenas ligando virgens católicas a nomes Náuatles; eles residem até nas áreas mais modernas de uma escala transnacional.

A arquitetura formal utilizada por ambos transmite sentidos por meio de linguagens e de convenções formais e a questão é sabermos se toda essa complexidade é o resultado de nossa época tão contraditória, a pós-moderna, ou se o sonho de "normalizarem" a linguagem e a liberdade da literatura chicana está inserido apenas na ficção. O contexto da necessidade de se mostrarem estilisticamente legitimados faz os autores contarem histórias para ampliar a retórica típica da "sua" identidade. Eles criam novos diálogos e inventam fantasias intertextualizadas que mudam crenças e expõem conformidades; transpõem "fronteiras" desconhecidas até então. 
Trata-se de uma visão que preserva os valores da tradição asteca, mas, ao mesmo tempo, conecta-nos a um outro mundo, o atual, fazendo-nos pensar como argumenta Donnan, que "as fronteiras são registros espaciais e temporais de conexões entre comunidades e entre estados" ["Borders are spatial and temporal records of relationships between local communities and between states".] (1998, p. 5).

Dessa maneira, para uma ideologia de poder baseada em teorias sobre fronteiras como o de Gómez-Peña e Anzaldúa, o melhor é considerarmos seus discursos pós-modernos como processos significativos de resistência. Ao assumirem a constante mudança entre o passado e o presente dos chicanos, esses textos possibilitam o questionamento sobre o destino do grupo e de sua produção artística. O primordial é destacar como essas escrituras podem mostrar novas perspectivas de abordagem da cultura e da tradição dos chicanos.

A partir dessa constatação, os textos de Anzaldúa e de Gómez-Peña apresentam referências conectadas a uma organização binária de pensamento que não fogem às noções da historicidade da tradição, mas mantém uma determinação política em retratar essa mesma historicidade com uma voz crítica. Os autores dão existência às complexas práticas do fenômeno Aztlán, assim como fundamentam sua retórica e, de maneira figural, formam a referencialidade de uma tradição asteca que se acreditava estar (quase) perdida para a literatura.

Dessa maneira, verificamos que eles fazem parte de uma força como grupo, assim como são autônomos em reproduzirem práticas referentes à universalidade chicana. Eles conseguem destacar-se como papel cultural que cumprem os megaeventos nessa reestruturação da vida pós-moderna, tanto quanto abastecem a história cultural das Américas como objetivo de estudos e análises. De um ponto de vista bastante próprio, eles afetam e tornam a promover outras atividades culturais, de informação e de participação nos meios sociais por onde circulam. Mais do que tudo, os autores desejam fazer uso da sua própria 
hegemonia, aquela que vem modificando formas de segregação e de violência, contribuindo para a compreensão entre culturas.

Anzaldúa e Gómez-Peña adotaram estratégias de comunicação que lhes permite alterar a composição literária consolidada na esfera artística.

Não nos surpreende, portanto, que os autores marquem uma postura de contestação quando se instrumentalizam para redescobrirem e reinscreverem o cânone literário em vigor. Eles retomam certos valores e sentidos aceitos de forma conotativa, mas parodiam outros contextos históricos de maneira menos ficcional. Avançam em seus propósitos literários, tanto quanto redimensionam a hegemonia europeia para nos fazer entender o funcionamento de se oporem às antigas formas dominantes. Os autores abrem espaço para a mudança que marca o momento pós-estruturalista, quando o chicano é visto como o significado cultural para formar a identidade chicana; marcam encontro para contestar os líderes que desejam manter o préestabelecido.

Nesse sentido, seus projetos visam substancializar a posição assumida na formação de um outro horizonte, aquela ampliação de sentido para alterarem a prática coletiva de se referir às fronteiras. Parece que já não se trata de algo apenas mimético, mas sim, de alguma coisa ultra-autônoma, antireferencial, engajada historicamente nessa mesma problemática. Eles apontam, com essa corrente, as limitações dos olhares críticos que persistem na sociedade norte-americana. Já não admitem serem apenas a diferença. Querem ser reconhecidos como a diversidade hegemônica manifestando-se em novas atualizações literárias nas fronteiras. Ainda de acordo com Donnan,

o estado é um objeto cuja realidade será negada se focalizarmos exclusivamente sobre suas representações descontruídas, e em nenhum outro lugar isso é mais evidente do que nas fronteiras onde o poder do estado está inscrito de forma descomunal. Nações e seus membros podem estar numa perpétua condição de vir-a-ser, mas isso é apenas parcialmente uma verdade do estado. $\mathrm{O}$ estado existe. Suas instituições e representantes fazem e executam leis que regem as atividades diárias de seus cidadãos e residentes, em direta relação de causa e efeito. As pessoas da fronteira, por causa de suas histórias e de suas culturas subjetiva e objetivamente instaladas, têm não apenas de lidar com as 
instituições de seu próprio estado, mas com aquelas instituições do estado ou estados além da fronteira, entidades de igual e soberano poder que ofuscam toda relação de fronteira. $(1998, \text { p. } 8)^{3}$

Por tudo isso, podemos nos referir às obras de Gómez-Peña e Anzaldúa como o poder literário de afirmação e resistência que deseja ser analisado como discurso para firmar uma posição. Eles não ignoram as formas históricas às quais retornaram muitas vezes, mas, numa reação contrária, fizeram uma outra história. A história do nascimento da Raza, o espetáculo universal da "nova consciência mestiza". O jogo que estabeleceram poderia ser considerado como pressupostos ideológicos da formação da Raza, a reativação da produção de pesquisas sobre os chicanos que se dá a oferecer a qualquer política cultural.

O poder de Gómez-Peña e Anzaldúa é reforçado em cada manifestação significativa de seus textos. Sua força encontra-se em um ponto que aborda toda e qualquer manifestação de vida sócio-cultural possibilitando, assim, lidarmos com formas e referências clássicas e modernas. Os autores também provocam a abertura para a possibilidade das esperadas fusões entre passado e futuro. As raízes de identidade pessoal os impele no tempo e na história. Gómez-Peña e Anzaldúa traçam um caminho para uma posição de diferença e experiência, ao mesmo tempo que servem para uma exposição mais organizada sobre o que significa ser chicano.

Dessa maneira, a obviedade de ideologia auto-reflexiva tanto de Anzaldúa quanto de Gómez-Peña, supõe o que seria impossível para alguém sustentar: os autores reverenciam sua Raza de forma ferrenha, organizando ideias associadas a diferentes ambientes culturais, intermediando realidades contrastantes. Capazes de curvarem-se criticamente sobre si mesmos, eles não conseguem se manter cegos às coisas que acontecem em seu próprio terreno e nas fronteiras. Eles adaptam aquilo que reconhecem como fundamental ao seu passado com vistas ao futuro, e lançam suas próprias colaborações criativas como representantes da estética pós-moderna. Nesses espaços locais fazem intervir milhares de participantes. 
Sujeita à mudança sócio-estética, a produção dos autores é autoconsciente e valorizada por suas inovações, complementando uma semiótica da cultura chicana. Como perspectivas futuras, seus textos influenciam posturas de oposição, assim como faz nascer a Raza, esta, referente histórico acessível a qualquer um que gostaria de marcar sua autenticidade artística tanto quanto o fazem Anzaldúa e Gómez-Peña. Mais do que qualquer coextensividade da cultura, os autores baseiam suas oposições nos critérios da arbitrariedade sem se esquecerem do contraponto à tradicional manifestação da cultura chicana, toda ela preocupada com os meios de comunicação de massa e, também, com a cultura como forma de dimensão social. Diferente da oposição de antes, agora eles se servem do palco dos debates públicos interagindo estética e reconhecidamente por todos.

Desse momento em diante, os nossos sentidos se estendem até o lugar onde a necessidade de se abordar a cultura chicana mostra-se como a produção e a difusão da diferença, o material simbólico representando a pluralidade do mundo pós-moderno.

\section{NOTAS}

1- "In the 1960s, I read my first Chicano novel. It was City of Night by John Rechy, a gay Texan, son of a Scottish father and a Mexican mother. For days I walked around in stunned amazement that a Chicano could write and could get published. When I read I am Joaquim I was surprised to see a bilingual book by a Chicano in print. When I saw poetry written in Tex-Mex for the first time, a feeling of pure joy flashed through me. I felt like we really existed as a people." (ANZALDÚA, 1999, p. 81-82)

2- "IN FEBRUARY OF 1995, THE FIRST STAGE OF A BINATIONAL PERFORmance project called "Terreno Peligroso/Danger Zone" was completed. For an entire month - two weeks in Los Angeles and two in Mexico City - eleven experimental artists whose work challenges stereo-typical and/or official notions of identity, nationality, language, sexuality, and the creative process worked together daily. Representing Mexico were Lorena Wolffer, Felipe Ehrenberg, Eugenia Vargas, César Martínez, and Elvira Santamaría; from California were Elia Arce, Rubén Martínez, Nao Bustamante, Luis Alfaro, Roberto Sifuentes, and myself. Chosen by the curators and producers, Josefina Ramírez and Lorena Wolffer, this group was as eclectic and diverse as our two cultures (Chicano and Mexican). The performances were presented at the University of California at Los Angeles (UCLA) and in the ExTeresa Arte Alternativo (Mexico City).

The performance work we did covered a wide spectrum, ranging from the most intimate ritual actions to the most confrontational activist performance; including tableaux vivants, avant-cabaret, spoken word poetry, apocalyptic rituals, and street "interventions". Our goals (at least those we consciously expressed) were: to create art together (border art is collaborative by nature); to open the Pandora's box of North/South relations and unleash the border demons; to destroy taboos; (...)". (GÓMEZ-PEÑA, 1996, p. 169) 
3- "the state is an object whose reality hill be denied if we focus exclusively on deconstructed representations of it, and nowhere is this more apparent than at borders, where the powers of the state are monumentally inscribed. Nations and their individuated members may be in a perpetual condition of becoming, but this is only partially true of the state. The state exists. Its institutions and representatives make and enforce the laws which regiment most daily activities of its citizens and residents, in direct relations of cause an effect. Border peoples, because of their histories, and objectified and subjectified cultures, not only have to deal with the institutions of their own state, but with those institutions of the state or states across the border, entities of equal and sovereign power which overshadow all border relations". (DONNAN, 1998, p. 8) 


\section{BIBLIOGRAFIA}

ACHARD, P., et al. Papel da memória. Tradução de José Horta Nunes. Campinas: Pontes, 1999.

ACUÑA, R. Occupied America. 3.ed. New York: Harper Collins, 1998.

ALARCÓN, J. S. La búsqueda de la identidad en la literatura chicana. Disponível em $<$ http://www.cervantesvirtual.com/servlet/Sirveobras/chic/1225163102015938421435/p00 $>$.

Acesso em: 24. abr. 2009.

ANDERSON, P. As origens da Pós-Modernidade. Tradução de Marcus Penchel. Rio de Janeiro: Jorge Zahar Editor, 1999.

ANZALDÚA, G. Borderlands / La frontera: The New Mestiza. 2nd ed. San Francisco: Aunt Lute Books, 1999.

; KEATING, A. This bridge we call home. New York: Routledge, 2002.

ARTAUD, A. O teatro e seu duplo. Tradução de Teixeira Coelho. Gallimard, Paris, 1964.

ARTEAGA, A. (Ed.) An Other Tongue: National Ethnicity in the Linguistic Borderlands. Durham, N. C.: Duke University Press, 1994.

BACCEGA, A. M. Palavra e discurso: Literatura e História. São Paulo: Ática, 2003.

BAKHTIN, M. Problemas da poética de Dostoievsk. Tradução de Paulo Bezerra. 3.ed. Rio de Janeiro:Forense Universitária, 2002.

BHABHA, H. K. O local da cultura. Tradução de Myrian Ávila, Eliana de Lima Lourenço Reis, Gláucia Renate Gonçalves. Belo Horizonte: UFMG, 1998.

BENAVIDEZ, M. Montaje chicano: Arte y Crisis Cultural. Disponível em $<$ http://www.zonezero.com/magazine/essays/distant/zmonta.html> . Acesso em: 17. fev. 2009.

BUTLER, J. Problemas de gênero: feminismo e subversão da identidade. Tradução de Renato Aguiar. Rio de Janeiro: Civilização Brasileira, 2003.

CANCLINI, N. G. A globalização imaginada. Tradução de Sérgio Molina. São Paulo: Iluminuras, 2003.

Cultural reconversion. In: Yúdice, Franco \& Flores. (eds.). On Edge - The Crisis of Contemporary Latin American Culture. Minneapolis. U of Minnesota P, 1992, p.42.

São Paulo: Edusp, 1997.

Culturas híbridas. Tradução de Ana Regina Lessa e Heloísa Pezza Cintrão.

CARRIZO, S. Mestiçagem. In: FIGUEIREDO, E. (Org.). Conceitos de literatura e cultura. Juiz de Fora: UFJF, 2005. p. 465-488. 
CEVASCO, M. E. A recepção dos Cultural Studies no Brasil. Cultura Vozes, 2, p.69-79, 1997. Dez lições sobre estudos culturais. São Paulo: Boitempo, 2003.

CHAUI, M. Cultura e democracia: O discurso competente e outras falas. 3.ed. São Paulo: Moderna, 1992.

CHIAMPI, I. (Coord.) Fundadores da Modernidade. São Paulo: Ática, 1991.

CHNAIDERMAN, M. Ensaios de psicanálise e semiótica. São Paulo: Escuta, 1989.

COHEN, R. Performance como linguagem: criação de um tempo-espaço de experimentação. 1.ed. São Paulo: Perspectiva, 2002.

CONNOR, S. Cultura pós-moderna. Introdução às Teorias do Contemporâneo. Tradução de Adail Ubirajara Sobral e Maria Stella Gonçalves. São Paulo: Edições Loyola, 1992.

COSTA LIMA, L. Pensando nos trópicos: (dispersa demanda II). Rio de Janeiro: Rocco, 1991.

CUCHE, D. A noção de cultura nas ciências sociais. Tradução de Viviane Ribeiro. Bauru: EDUSC. 1999.

DEBORD, G. A sociedade do espetáculo. 4.ed. Tradução de Estela dos Santos Abreu. Rio de Janeiro: Contraponto, 2002.

DELEUZE, G.; GUATTARI, F. Mil Platôs: capitalismo e esquizofrenia. Vol 3. Tradução de Aurélio Guerra Neto et alii. Rio de Janeiro: Ed. 14, 1996.

DONNAN, H.; WILSON, T. M. (editores) Border identities: nation and state at international frontiers. Cambridge: University Press, 1998.

EAGLETON, T. Ideologia. Uma introdução. Tradução de Silvana Vieira, Luís Carlos Borges. São Paulo: Boitempo, 1997.

Press, 1983.

Literary Theory: an introduction. Minneapolis: University of Minnesota The Idea of Culture. Maiden: Blackwell, 2000.

FIORIN, J. L. As astúcias da enunciação. 2.ed. São Paulo: Ática, 2001.

ECO, H. Travels in hiper reality. Harcourt Brace \& Company: Florida, 1986.

FOUCAULT, M. Estética: literatura e pintura, música e cinema. Tradução de Inês Autran Dourado. Rio de Janeiro: Forense Universitária, 2001.

Rio de Janeiro: Jorge Zahar, 2001b.

Foucault, a filosofia e a literatura. 2.ed. Tradução de Roberto Machado. 
História da sexualidade. 5.ed. Tradução de Maria Tereza da Costa

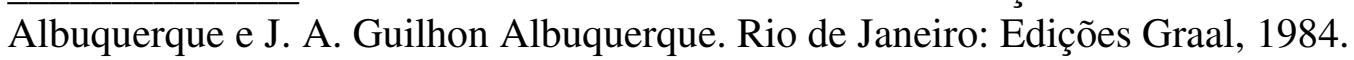

flesh, p. 196. Power/Knowledge. Brighton: Harvester Press, 1980. The confession of the

FREUD, S. Obras Completas. 4.ed. Madrid: Biblioteca Nueva, 1981.

GEERTZ, C. A interpretação das culturas. Rio de Janeiro: Guanabara-Koogan, 1989.

GÓMEZ-PEÑA, G. The New World Border. San Francisco: City Lights Books, 1996.

GREIMAS, A. J; COURTÉS, J. Dicionário de semiótica. Tradução de Alceu Dias Lima et al. São Paulo: Cultrix, 1979.

GROTOWSKI, J. Em busca de um teatro pobre. Tradução de Aldomar Conrado. Rio de Janeiro: Civilização Brasileira, 1971.

GUIRADO, M. Psicanálise e análise do discurso - matrizes institucionais do sujeito psíquico. São Paulo: Summus, 1995.

HALL, S. A identidade cultural na pós-modernidade. 7.ed. Tradução de Tomaz Tadeu da Silva e Guacira Lopes Louro. Rio de Janeiro: DP\&A, 2003.

HUTCHEON, L. Poética do pós-modernismo: história, teoria, ficção. Tradução de Ricardo Cruz. Rio de Janeiro: Imago, 1991.

KEHL, M. R. Deslocamentos do feminino: a mulher freudiana na passagem para a modernidade. Rio de Janeiro: Imago, 1998.

. Minha vida daria um romance. In: BARTUCI, G. (Org.) Psicanálise, literatura e estéticas de subjetivação. Rio de Janeiro: Imago, 2001.

KRISTEVA, J. Estrangeiros para nós mesmos. Tradução de Maria Carlota Carvalho Gomes. Rio de Janeiro: Rocco, 1994.

Terra, 1988.

Histórias de amor. Tradução de Leda Tenório da Motta. Rio de Janeiro: Paz e

JAMESON, F. O inconsciente político: a narrativa como ato socialmente simbólico. Tradução de Valter Lellis Siqueira. São Paulo: Ática, 1992.

Pós-Modernismo: A Lógica cultural do Capitalismo Tardio. Tradução de Maria Elisa Cevasco. São Paulo: Ática, 1996.

LYOTARD, J. F. A condição Pós-Moderna. Tradução de Ricardo Corrêa Barbosa. 7.ed. Rio de Janeiro: José Olympio, 2002. 
MACIEL, D. R.; ORTIZ, I. D.; SOBEK, M. H. Chicano renaissance: contemporary cultural trends. Tucson: The University of Arizona Press, 2000.

MIGNOLO, W. D. Histórias locais / Projetos globais: colonialidade, saberes subalternos e pensamento liminar. Tradução de Solange Ribeiro de Oliveira. Belo Horizonte: UFMG, 2003.

MOREIRAS, A. A exaustão da diferença. A política dos estudos culturais latino-americanos. Tradução de Eliana Lourenço de Lima Reis e Gláucia Renate Gonçalves. Belo Horizonte: UFMG, 2001.

NASIO, JD. O livro da dor e do amor. Tradução de Lucy Magalhães. Rio de Janeiro: Jorge Zahar, 1997.

NITRINI, S. Literatura comparada: história, teoria e crítica. 2.ed. São Paulo: Ed. Da USP, 2000 .

ORLANDI, E. P. Interpretação: autoria, leitura e efeitos do trabalho simbólico. 3.ed. Rio de Janeiro: Vozes, 1996.

Discurso e Texto: formação e circulação dos sentidos. São Paulo: Pontes, 2001.

ORTIZ, F. Contrapuento cubano del tabaco y el azúcar. Madrid: Cátedra, 2002.

PAZ, O. El laberinto de la soledad y otras obras. New York: Penguin Books, 1997.

PENNA, J. C. Este corpo, esta dor, esta fome: notas sobre o testemunho. In: SELIGMANNSILVA, M. (Org.). História, memória, literatura: o Testemunho na era das Catástrofes. Campinas: UNICAMP, 2003.

PÉREZ-TORRES, R. Movements in Chicano Poetry. New York: Cambridge University Press, 1995.

REIS, L. de F. Transculturação e transculturação narrativa. In: FIGUEIREDO, E. (Org.). Conceitos de literatura e cultura. Juiz de Fora: UFJF, 2005. p. 465-488.

RINCÓN, C. La no simultaneidad de lo simultáneo: Postmodernidad, globalización y culturas en América Latina. 2.ed. Bogota: EUN, 1995.

SALDÍVAR, J. D. Border Matters: Remapping American Cultural Studies. London: University of California Press, 1997.

; CALDERÓN, H. Criticism in the Borderlands: Studies in Chicano Literature, Culture, and Ideology. Durham, North Carolina: Duke University Press, 1991.

SANTAELLA, L. Corpo e comunicação: sintoma da cultura. São Paulo: Paulus, 2004. Paulo: Paulus, 2003.

Culturas e artes do pós-humano: da cultura das mídias à cibercultura. São 
SANTIAGO, S. Uma literatura nos trópicos: ensaios sobre dependência cultural. 2.ed. Rio de Janeiro: Rocco, 2000.

Nas malhas da letra: ensaios. Rio de Janeiro: Rocco, 2002.

SELIGMANN-SILVA M. Reflexões sobre a memória, a história e o esquecimento. In: SELIGMANN-SILVA, M. (Org.). História, memória, literatura: o Testemunho na Era das Catástrofes. Campinas: Editora da UNICAMP, 2003.

SILVA, T. T. O que é afinal, estudos Culturais? 2.ed. Belo Horizonte: Autêntica, 2000.

SOJA, E. Heterotopologies and the Geohistory of Otherness. In: Thirdspace. Cambridge, Mass: Blackwell, 1996, p.145-63.

STAVENHAGEN, R. Multiculturalidade e políticas de desenvolvimento. In: CANCLINI, N. G. (Coord.) Culturas da Ibero-América: Diagnósticos e propostas para seu desenvolvimento. Tradução de Ana Venite Fuzato. São Paulo: Moderna, 2003.

STOREY, J. Cultural Studies and the Study of Popular Culture: Theories and Methods. Athens: University of Georgia Press, 1998a.

Press, 1983.

Literary Theory: an introduction. Minneapolis: University of Minnesota

STRINATI, D. Cultura Popular: uma introdução. 1.ed. Tradução de Carlos Szlack. São Paulo: Hedra, 1999.

TORRES, S. Nosotros in USA: literatura, etnografia e geografias de resistência. Rio de Janeiro: Jorge Zahar, 2001.

. (Org.) Raízes e rumos: perspectivas interdisciplinares em estudos americanos.

Rio de Janeiro: 7Letras, 2001 b.

YÚDICE, G. A conveniência da cultura: usos da cultura na era global. Tradução de MarieAnne Kremer. Belo Horizonte: UFMG, 2004

Puede hablarse de postmodernidad en America Latina? Revista de crítica literária Latino Americana. Lima, año XV, nº 29, 1 semestre de 1989, p.105-128.

ZIZEK, S. (Org.) Um mapa da ideologia. Tradução de Vera Ribeiro. Rio de Janeiro: Contraponto, 1999. 